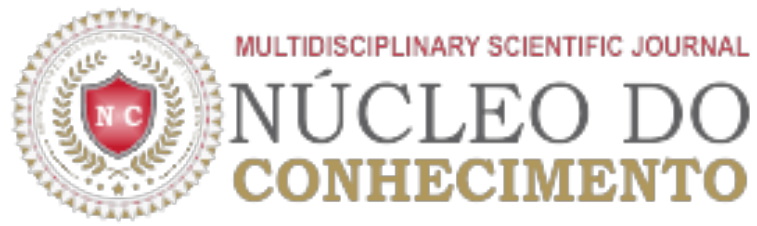

\section{A Educação Prisional no Mercosul, Unidade Prisional de Bom Jesus, Estado do Piauí, Brasil}

\author{
NOVO, Benigno Núñez ${ }^{[1]}$
}

NOVO, Benigno Núñez. A Educação Prisional no Mercosul, Unidade Prisional de Bom Jesus, Estado do Piauí, Brasil. Revista Científica Multidisciplinar Núcleo do Conhecimento. Edição 05. Ano 02, Vol. 01. pp 564-783, Julho de 2017. ISSN:2448-0959

\section{RESUMO}

Este estudo tem por objetivo demonstrar um panorama atual da situação em que se encontra o sistema educativo prisional no MERCOSUL que é administrado na penitenciária de Bom Jesus, Estado de Piauí, Brasil, tendo como primeira hipótese examinar o papel da educação dentro do "Programa de Recuperação" na política de transformação e recuperação do condenado. Como segunda hipótese procura demostrar à importância do ensino ministrado na escola com base na realidade local do condenado. $\mathrm{O}$ desenho desse estudo é não experimental, transversal, do tipo descritivo. Através da análise de diversos documentos, das experiências com os estudantes e de uma recopilação dos questionários com professores, detentos e gerente a respeito do sistema implementado que é o modelo de política pública para a educação aplicada na escola da prisão de Bom Jesus, tendo uma história recente, busca-se entre outras questões, compreender o papel que desempenha a educação básica na penitenciária, buscando descrever e analisar a relação entre a educação escolar e a recuperação dos presos. Ademais, o trabalho se determina a examinar a educação desenvolvida na prisão com base no próprio exame interno que foi realizado com os condenados a respeito do programa educativo de que eles participam. Dada a especificidade da questão e a atenção a escassa produção de literatura científica neste campo de estudo, acredita-se que este material pode contribuir para levantar a discussão no âmbito da educação penitenciária que existe até hoje, na realidade, a recuperação dos condenados tem sido uma preocupação para os advogados, cientistas sociais e psicólogos, quando deveria ser uma preocupação de toda a sociedade.

Palavras-Chave: Condenados, Sistema Educativo Administrado na Penitenciária, Educação de Jovens e Adultos, Recuperação, Preocupação de Toda a Sociedade.

\section{INTRODUÇÃO}


O estabelecimento da prisão como instrumento da pena se deu pelo Código Penal Francês em 1791 e generalizou-se no mundo. A prisão surgiu no fim do Século XVIII e princípio do Século XIX com o objetivo de servir como peça de punição. A criação de uma nova legislação para definir o poder de punir como uma função geral da sociedade, exercida da forma igual sobre todos os seus membros. Foucault (1987) diz que a prisão se fundamenta na "privação de liberdade", salientando que esta liberdade é um bem pertencente a todos da mesma maneira, perdê-la tem, dessa maneira, o mesmo preço para todos, "melhor que a multa, ela é o castigo", permitindo a quantificação da pena segundo a variável do tempo: "Retirando tempo do condenado, a prisão parece traduzir concretamente a idéia de que a infração lesou, mais alem da vitima a sociedade inteira" (Foucault, 1987, p. 196).

O crescimento vertiginoso da população prisional e do déficit de vagas, a despeito dos esforços dos governos dos estados e da federação para a geração de novas delas, é por seu turno um elemento revelador de que a construção de novas unidades não pode mais ser o componente fundamental das políticas penitenciárias, senão que apenas mais um componente, dentro de um mosaico bem mais amplo. Pesquisas recentes estimam, por exemplo, que mais de 60\% (sessenta por cento) da população prisional seja composta por reincidentes (talvez não no sentido técnico-jurídico do termo, mas no sentido de que saíram do sistema e a ele vieram a retornar, em situação de reinclusão), o que aponta, dentre outras coisas, para o papel absolutamente deficitário que vem sendo desempenhado pelo assim chamado tratamento penal, nas unidades prisionais do país. É bem verdade que entre a superlotação de estabelecimentos penitenciários e a qualidade desses serviços subsiste uma relação de mútua implicação. Mas ainda assim, restam ainda outros fatores que devem ser trabalhados junto à gestão dos sistemas penitenciários estaduais, como estratégias para torná-los melhores.

O nível educacional geralmente baixo das pessoas que entram no sistema carcerário reduz seus atrativos para o mercado de trabalho. Isso sugere que programas educacionais pode ser um caminho importante para preparar os detentos para um retorno bem-sucedido à sociedade. Reconhecendo essa possibilidade, a LEP determina que os detentos recebam oportunidades de estudo, garantindo-lhes, em especial, educação escolar primária. A lei também promete aos detentos treinamento vocacional e profissional.

A educação no sistema penitenciário é iniciada a partir da década de 1950. Até o principio do Século XIX, a prisão era utilizada unicamente como um local de contenção de pessoas - uma detenção. Não havia proposta de requalificar os presos. Esta proposta veio a surgir somente quando se desenvolveu dentro das prisões os programas de tratamento. Antes disso, não havia qualquer forma de trabalho, ensino religioso ou laico.

Assim, somente nos meados dos anos 50, constatou-se o insucesso deste sistema prisional, o que motivou a busca de novos rumos, ocasionando na inserção da educação escolar nas prisões. Foucault (1987, p. 224) diz: "A educação do detento é, por parte do poder público, ao mesmo tempo uma precaução indispensável no interesse da sociedade e uma obrigação para com o detento, ela é a grande força de pensar."

A grande maioria dos indivíduos presos não tiveram melhores oportunidades ao longo de suas vidas, principalmente a chance de estudar para garantir um futuro melhor. Nesse sentido, o tempo que despenderá atrás das grades pode e deve ser utilizado para lhe garantir estas oportunidades que nunca teve, por meio de estudo e, paralelamente, de trabalho profissionalizante. Além de ajeitar as celas, lavar 
corredores, limpar banheiros etc., os detentos precisam ter a chance de demonstrarem valores que, muitas vezes, encontram-se obscurecidos pelo estigma do crime. Existem casos de detentos que demonstram dotes artísticos, muitos deles se revelando excelentes pintores de quadros e painéis de parede, além de habilidades com esculturas, montagens, modelagens, marcenaria etc. Também, decoram as celas de acordo com sua criatividade e sua personalidade. Estas artes devem ser incentivadas, pois é uma forma de ocupar o preso, distraindo-o e aumentando sua auto-estima. É a chance de mostrar a ele de que existe a esperança de um amanhã melhor além das grades que o separam do mundo exterior.

As superlotações, os envolvimentos de presos em organizações criminosas e a falha de pessoal, são os principais problemas enfrentados pelas penitenciárias brasileiras. Outro fator que estamos acostumados a ver nos noticiários é a questão das rebeliões em presídios, sempre com resultados lastimáveis de sentenciados que são mortos por seus próprios companheiros, funcionários e familiares de detentos transformados em reféns, resgates e fugas audaciosas e espetaculares realizadas por criminosos, e por fim, a incapacidade das autoridades em face de organizações de criminosos, cada vez mais presente nos Estados brasileiros.

Assistência ao Preso, ao Internado, ao Egresso e aos seus Dependentes faz referência a um movimento de promoção dos direitos dos apenados, internados, egressos, dependentes e familiares, criando condições para que estes possam exercer a sua autonomia. Esse processo deve ser mediado pela inclusão dos beneficiários na agenda das políticas públicas de governo e pelo apoio a ações de instituições públicas e privadas, de caráter permanente, que tenham como objetivo prestar atendimento aos beneficiários, na forma e nos limites da lei: material, jurídica, educacional, social, religiosa e principalmente à saúde ao egresso, após a edição do Plano Nacional de Saúde no Sistema Penitenciário.

Com efeito, a educação precisa transmitir significados presentes na vida concreta de quem se pretendem educar ou reeducar; de modo diverso, não produz resultado, aprendizagem.

Mediante a consciência reflexiva, simbólica, o homem desenvolve a linguagem, utilizando-se da palavra; dá sentido à vida, segundo os significados que advêm fundamentalmente dos símbolos, das palavras, dos nomes. Assim, os conceitos (símbolos) são necessários às experiências dos indivíduos em conexão à realidade. Logo, o processo da aprendizagem precisa mobilizar tanto os significados, os símbolos, quanto os sentimentos, as experiências a que eles se referem.

O sistema prisional dos Estados Unidos tem seus alvos. As minorias são as mais afetadas. Seus "clientes" são basicamente pobres, negros e latinos (rabble class). Os negros representam a minoria da população, mas são a maioria dentro dos presídios. Um de cada 19 homens negros está na prisão. Enfim, segundo John Irwin, "o encarceramento serve para governar a ralé".

Na Europa, numerosos países aprovaram leis que garantem o direito dos presos à educação. Essas normas legais apresentam geralmente muita semelhança, embora, principalmente nos países do Leste europeu, observe-se uma distância considerável entre o que prescrevem as leis e a vida cotidiana nas prisões.

Na América Latina, a reabilitação prisional, pretendida pela legislação penal, tem patenteado, na prática, o desalento, a aflição e a definitiva rebeldia contra uma sociedade que fecha as portas ao egresso.

A educação deve ser vista como um direito, não para a reintegração. Claro que isso é muito importante, mas se a reintegração for impossível, a educação continua a ser um direito. Não devemos instrumentalizar 
a educação unicamente para um papel social ou do tipo político-social. A educação pode ser uma solução se for uma educação ao longo da vida, não apenas do tipo profissional ou a reeducação. É para muitos presos a primeira oportunidade de compreender sua história e de tratar de desenvolver seu próprio projeto de vida.

No Estado do Piauí os presos de todas as penitenciárias públicas estaduais são beneficiados com o programa Educando para a Liberdade.

Na prisão, o trabalho, qualquer que seja sua tradução em atividades, é considerado educativo; a educação escolar, por sua vez, não é considerada trabalho intelectual.

A remição pelo estudo, no entanto, deve vir acompanhada de outras medidas que possibilitem e valorizem as atividades educativas no interior dos presídios.

A pesquisa é uma atividade voltada para a solução de problemas, através do emprego de processos científicos, e que parte de uma dúvida ou problema que com o uso do método científico busca uma resposta ou solução.

O desenho desse estudo é não experimental, transversal, de tipo descritivo. A pesquisa foi sem manipular deliberadamente as variáveis trata-se de uma pesquisa em que não fazemos variar intencionalmente as variáveis independentes. O modelo é transversal por que o procedimento consiste em situar um grupo de pessoas num contexto.

A educação é importante na recuperação, muitos detentos têm baixos padrões de escolaridade. Uma parcela significativa não domina as competências básicas de leitura e escrita, esse baixo nível de escolaridade afetou suas vidas e pode ter contribuído para que cometessem delitos, por isso os programas e projetos de educação nos presídios são importantes para desenvolver nos encarcerados seu senso de autovalorização.

Nossa pergunta do problema é a seguinte:

De que maneira a educação prisional pode se tornar um instrumento na recuperação de detentos do MERCOSUL, na Unidade Prisional de Bom Jesus no Estado do Piauí, Brasil?

O objetivo geral da pesquisa é o seguinte: Investigar como a educação pode se tornar um instrumento na recuperação de detentos da Unidade Prisional de Bom Jesus no Estado do Piauí, Brasil.

Os objetivos específicos da pesquisa são: 1) Descrever os projetos, técnicas e métodos educacionais que podem ser aplicadas para resultados no melhoramento dos índices de recuperação de detentos da Unidade Prisional de Bom Jesus no Estado do Piauí, Brasil; 2) Verificar as condições para aumentar a oferta de ensino na unidade Prisional de Bom Jesus; 3) Identificar a realidade carcerária atual no aspecto da formação adequada dos profissionais da área de educação voltado para a realidade da Unidade Prisional de Bom Jesus.

Esta pesquisa justifica-se da seguinte maneira: A educação é um dos instrumentos importantes na recuperação, muitos detentos têm baixos padrões de escolaridade. Uma parcela significativa não domina 
as competências básicas de leitura e escrita, esse baixo nível de escolaridade afetou suas vidas e pode ter contribuído para que cometessem delitos.

Os programas e projetos educacionais precisam ser desenvolvidos dentro das prisões para que se trabalhe a conscientização dos educandos ajudando a desenvolver seu senso de autovalorização. Pois um indivíduo que nasceu na miséria e por conseqüência não teve acesso a uma educação satisfatória ou a de nenhum tipo, não pode agir com discernimento em seus atos.

A delimitação e alcance desta pesquisa são relevantes cientificamente e contribuem para mudar e melhorar o processo ensino-aprendizagem da escola da penitenciária de Bom Jesus que se diga não se finda por aqui tal estudo devendo ser continuado porque como dissemos anteriormente a educação é processo que necessita constantemente ser aprimorado, melhorado e que não se esgota.

Os resultados serão úteis para os Estados Partes do MERCOSUL, para a Secretaria da Justiça e dos Direitos Humanos do Estado do Piauí, Secretaria Estadual de Educação e Cultura do Estado do Piauí, Gerência da Penitenciária Regional de Bom Jesus e para a $14^{\text {a }}$ Gerência Regional de Educação de Bom Jesus.

Em efeito, este estudo está estruturado em capítulos da seguinte forma: No capítulo primeiro é feita a revisão do tema Prisão, os Sistemas Penitenciários Clássicos e um histórico sobre a prisão.

Nos capítulos segundo e terceiro é tratado o marco teórico do estudo. Nele se desenvolvem os fundamentos teóricos de diferentes autores sobre o objeto de estudo. A Falta de Acesso à Educação e as Realidades do Sistema Prisional Brasileiro, a Reintegração Social demonstrando que o grande desafio é recuperar e reintegrar o detento na comunidade, mas para isso é necessário diagnosticar os que desejam trabalhar e estudar. Os efeitos nocivos do encarceramento sobre os condenados impossibilitam qualquer tentativa de recuperação, não havendo como se falar em reinserção e reeducação em um ambiente de exclusão e exploração ao quais os presos estão submetidos, características estas que exercem, na verdade, uma função marginalizadora, sendo um fator criminógeno de educação e promoção ao crime e ao trabalho praticamente escravo.

Na prisão, o trabalho, qualquer que seja sua tradução em atividades, é considerado educativo; a educação escolar, por sua vez, não é considerada trabalho intelectual.

O capítulo quarto apresenta a necessidade do estímulo para educação e trabalho, as dificuldades do exercício do direito à educação e como o uso das tecnologias como a escola virtual podem ajudar na recuperação de detentos.

No quinto capítulo o estudo do Sistema Prisional do Estado do Piauí com destaque para a Unidade Prisional de Bom Jesus.

No capítulo sexto é tratada a Metodologia. Neste capítulo se prepara o projeto para o trabalho de campo, descrevendo brevemente o lugar de estudo, identificando as fontes de dados, explicando o tipo e método de estudo, especificando a elaboração e validação dos instrumentos de pesquisa, e aclarando as técnicas de analise de dados. 
O capítulo sétimo apresenta a discussão e a análise dos resultados. Nele se elaboram um sistema de organização e apresentação dos dados.

No oitavo capítulo se apresentam as conclusões e recomendações. As conclusões mais importantes, os pontos fortes da pesquisa a partir dos objetivos atingidos, o alcance dos objetivos específicos e a confirmação das hipóteses através dos resultados obtidos.

\section{A PRISÃO}

\subsection{HISTÓRICO}

Ao buscar a origem da prisão a partir do surgimento da civilização, constata-se que na Antiguidade, mais precisamente na Roma Antiga prevaleciam as penas corporais e de morte, sendo que a prisão constituía meio para encarcerar os acusados somente até o julgamento ou execução.

Naquela época, não existia um local certo com uma arquitetura prisional definida para recolher os encarcerados, os quais ficavam geralmente em fortalezas reais, calabouços, torres ou edifícios diversos. Messuti (2003, p. 28) registra que existiam em Jerusalém quando houve a invasão dos caldeus, três prisões que se localizavam uma no portal de Benjamin, outra no palácio do rei e a última na residência de um funcionário público.

Afora estas experiências isoladas de prisão, segundo Leal (2001, p. 33) foi a Igreja que, na Idade Média, inovou ao castigar os monges rebeldes ou infratores com o recolhimento em celas localizadas em uma ala própria do mosteiro com o fim de recolhimento e oração.

A Idade Média, também, é marcada pelo aspecto estritamente punitivo da pena através do sofrimento físico corporal infligido aos acusados para libertação da alma com os suplícios, a forca, a roda.

No século XVI, com a crise do sistema feudal e a migração da população dos campos para as cidades com cenário de pobreza e miséria na Europa, o aumento da criminalidade foi inevitável e forçou a construção de várias prisões para segregar mendigos, prostitutas e vagabundos com o fim disciplinar e corretivo através do trabalho, especialmente pelos crimes cometidos contra o patrimônio que não se solucionariam com a pena de morte que fatalmente exterminaria milhares de delinqüentes assolados pela fome.

Nesta época, a prisão mais antiga de acordo com Leal (2001, p. 34) foi a House of Correction, inaugurada em 1552 na cidade de Bridewell, na Inglaterra, com disciplina extremamente rígida para emenda dos delinquentes.

Outro modelo de inspiração para época foi o de Rasphuis de Amsterdam, inaugurado em 1596, onde o trabalho era obrigatório, a cela individual era utilizada somente a título de punição com vigilância contínua e leituras espirituais.

Percebe-se, desta forma, que a prisão surgiu para a segregação de mendigos, prostitutas e vagabundos, fato sociológico que merece registro pela atualidade da problemática da população carcerária atual, não se olvidando da sua finalidade: corretiva através do labor. 
A partir desta época, começou a se desenvolver estudos e idéias sobre o sistema penitenciário, especialmente a preocupação com a questão humanitária da prisão, destacando-se dentre os mais importantes: a obra Reflexões sobre as prisões monásticas de Jean Mabillon (1695), o clássico revolucionário Dos Delitos e das Penas de Cesare Beccaria (1764), O Estado das Prisões na Inglaterra e no País de Gales de John Howard (1776).

\subsection{SISTEMAS PENITENCIÁRIOS CLÁSSICOS}

As teorias de execução das penas, sustentadas por Cesare Beccaria, John Howard e Jeremias Bentham, germinaram, nos Estados Unidos, no século XVIII, o movimento de criação de sistemas penitenciários padronizados, cujos mais famosos foram experimentados em colônias prisionais sob o influxo do notável político Benjamin Franklin, autor da Constituição norte-americana de 1787, que, no campo do Direito Penal, escreveu, em 1723, a obra From Liberty and From Necessity of Penalty's Pleasure (Da Liberdade e da Necessidade do Prazer da Pena).

Os Sistemas Penitenciários Clássicos, que prosperaram nos Estados Unidos, na Europa e serviram de modelo para o mundo, a partir do século XIX, foram também incitados por organizações comunitárias, objetivando suavizar a vida dos condenados nas prisões. A mais famosa dessas organizações foi a Philadelphia Society for Alleviating the Miseries of Public Prisons (Sociedade de Philadephia para Aliviar a Miséria das Prisões Públicas), criada em 1787, que conseguiu introduzir modificações nas leis penais, como a abolição dos trabalhos forçados, dos açoites e das mutilações, além de restrições ao emprego da pena de morte que passou, em 1794, a ser aplicada, na Philadephia, apenas aos homicídios dolosos.

Os Sistemas Penitenciários Clássicos são:

1. Sistema Pensilvânico; 2. Sistema Auburniano; 3. Sistema Progressivo Inglês; 4. Sistema Progressivo Irlandês; 5. Sistema de Elmira; 6. Sistema de Montesinos; e 7. Sistema Borstal.

\subsubsection{O SISTEMA PENSILVÂNICO}

O Sistema Pensilvânico, também conhecido como Sistema de Philadephia, foi implantado na Eastern Penitentiary, na Philadelphia, em 1829, cuja construção foi inspirada na Penitenciária Panopticon idealizada por Jeremias Bentham, na Inglaterra. A base do Modelo Pensilvânico era o isolamento celular, com trabalho no próprio interior da cela, separando os presos para evitar promiscuidade e fazer com que todos meditassem sobre seus crimes com o objetivo de melhora pessoal. A solidão foi tão cruel, no estado de espírito dos enclausurados, que muitos foram vítimas de loucura. Somente podiam visitar os presos o diretor do estabelecimento, os guardas, o capelão e os membros da Sociedade de Philadelphia para Aliviar a Miséria das Prisões Públicas.

A única leitura permitida era a Bíblia. O completo isolamento em relação ao mundo exterior não permitia nem mesmo receber ou enviar cartas. O Modelo Pensilvânico serviu de orientação para os regimes celulares da Europa, começando em prisões da Inglaterra, Alemanha e Bélgica com as devidas adaptações nesses países.

\subsubsection{O SISTEMA AUBURNIANO}


O Sistema Auburniano foi implementado na Penitenciária de Auburn, em Nova Iorque, a partir do ano de 1818. Impunha o trabalho em comum durante o dia, sob absoluto silêncio, punindo com variados castigos qualquer tentativa de comunicação. À noite, o isolamento celular também era absoluto para descanso da labuta diária e como meio de evitar a corrupção dos condenados. Por isso, ficou conhecido nos Estados Unidos como silent system. Os presos não podiam, inclusive, receber visitas, nem mesmo de familiares e eram proibidos exercícios e distrações de qualquer espécie, com direito apenas a rudimentar instrução e aprendizado proporcionados pelos funcionários da prisão. Interessante anotar que a desumana imposição das regras do silêncio propiciou o aparecimento da linguagem indireta, utilizada, universalmente, até hoje pelos presos, por via de gestos, leitura dos dedos ou dos lábios e pancadas nas paredes.

Uma lei de 1821, do Estado de Nova Iorque, determinou que os presos de Auburn ficassem divididos em três classes: a) delinqüentes mais velhos e mais perigosos, que deveriam ficar em isolamento celular completo; b) delinqüentes que deveriam ficar trancados, em suas celas, três dias por semana; c) delinqüentes que deveriam ficar isolados apenas um dia por semana. Nos demais dias, os delinqüentes da segunda e da terceira classes deveriam trabalhar em silêncio absoluto.

A Penitenciária de Auburn foi construída pelos próprios presos, com 108 celas propícias ao silêncio e ao isolamento. As críticas ao sistema começaram, quando foram constatados vários casos de mortes provocadas pela tuberculose e pela loucura. Mesmo assim, o Sistema Auburniano era o sistema da preferência norte-americana, enquanto que o Sistema Pensilvânico era o mais adotado na Europa.

\subsubsection{O SISTEMA PROGRESSIVO INGLÊS}

O Sistema Progressivo Inglês surgiu na Inglaterra, em 1840, motivado pelas deficiências correcionais e reformadoras do Modelo Pensilvânico e do Modelo Auburniano.

Sua origem é atribuída ao capitão da Marinha real inglesa Alexander Maconochie que, sensibilizado com as péssimas condições dos presos, especialmente os que eram deportados nos enfers flottants para a Austrália, resolveu idealizar um sistema diferenciado que representasse a substituição dos anteriores sistemas de repressão. Maconochie introduziu esse novo sistema, chamado de Mark System, na Prisão da Ilha de Norfolk, na Austrália, onde era diretor, e lá cuidava dos presos deportados pela Justiça da GrãBretanha.

O Mark System estabeleceu uma forma de indeterminação da pena, que era medida em razão do trabalho, da boa conduta do condenado e levando em conta a gravidade do delito praticado. Com base nesses três fatores, eram atribuídas marcas ou vales, diariamente, que poderiam ser subtraídas em razão de faltas praticadas. Ao obter determinado número de marcas ou vales, o condenado era posto em liberdade.

O Mark System alcançou excelentes resultados, por isso passou a ser aplicado em toda a Inglaterra, com a adoção de três períodos progressivos, daí o nome Modelo Progressivo. O primeiro período era chamado de período de prova, implicava em isolamento celular completo diurno e noturno, com trabalho isolado e obrigatório durante o dia. Quando atingia quatro marcas ou vales, o apenado passava para o segundo período, onde era imposto o isolamento noturno, porém, durante o dia, ele era submetido a trabalho em comum sob a regra do silêncio nos Public Work-Houses (Casas de Trabalho Público). Continuando a ser beneficiado com quatro marcas ou vales, o condenado chegava ao terceiro período, onde, após certo 
tempo e com bom comportamento, alcançando as quatro marcas ou vales, podia obter o ticket of leave, uma espécie de livramento condicional.

\subsubsection{O SISTEMA PROGRESSIVO IRLANDÊS}

O Sistema Progressivo Irlandês foi criado por Walter Crofton, em 1854, então diretor das prisões da Irlanda.

Esse sistema difere do Sistema Progressivo da Inglaterra em dois pontos. Em primeiro lugar, o Sistema Inglês contém três períodos de execução da pena, enquanto no Irlandês há quatro, pois Crofton introduziu um período intermediário entre a prisão em comum (segundo período do Sistema Inglês) e o livramento condicional. Nesse período intermediário, com o feitio de antecedente da prisão aberta, foi adotado o trabalho externo que preparava o preso para o futuro livre com a obtenção do ticket of leave (liberdade condicional).

Outro detalhe diferenciado do Sistema Progressivo Irlandês, em relação ao Inglês, residia no fato dos detidos não serem obrigados aguardar silêncio durante o trabalho em comum.

O Sistema Progressivo Irlandês, pelas benéficas modificações experimentadas, no sentido de oferecer ao condenado vantagens por etapas, passou a influir, positivamente, nos aprimoramentos dos regimes da Europa e dos Estados Unidos, espraiando-se posteriormente por todos os continentes.

\subsubsection{O SISTEMA DE ELMIRA}

Com base no Sistema Progressivo Irlandês, surgiram nos Estados Unidos, os Regimes de Reformatórios, cujo mais famoso foi o Sistema do Reformatório de Elmira, no Estado de Nova Iorque em 1869.

Com o Reformatório de Elmira, a reação contra a criminalidade pela cura do condenado se apresenta mais claramente na evolução prática da política penitenciária. Criou-se o sistema unitário de pena e medida de segurança, mediante o critério de avaliação do condenado. Só admitia jovens delinqüentes entre 16 e 30 anos de idade, sujeitos a uma pena relativamente indeterminada com a fixação de um mínimo e de um máximo. Após o condenado passar por uma classificação inicial, era submetido a um sistema de marcas ou vales, concedidas em razão da evolução no trabalho, boa conduta, instrução moral e religiosa. O aprendizado de um ofício era obrigatório e a disciplina era do tipo militar. Quando alcançava a terceira fase, o apenado tinha direito ao livramento condicional e recebia um pecúlio, como forma de ajuda financeira para as primeiras necessidades.

Em 1915, não só Elmira, mas todos os regimes de reformatórios começaram a declinar nos Estados Unidos. As críticas mais fortes residiam no fato de que os jovens ficavam deprimidos com a rigorosa disciplina militar, castigos pesados e um ambiente de segurança máxima que não condizia com o sentido teórico de reformulação moral para a regeneração do condenado. Na verdade, começava a surgir nos Estados Unidos, com repercussão na Europa, o entusiasmo pela adoção das prisões abertas.

\subsubsection{O SISTEMA DE MONTESINOS}

Em 1835 o coronel Manuel Montesinos e Molina foi nomeado governador do Presídio de Valência, na 
Espanha, onde procurou implantar um diferenciado e eficiente regime prisional, cujo êxito lhe valeu o reconhecimento pelo grande esforço empreendido em busca de um exercício humanitário na prisão. Seu lema era: "os maus tratos irritam mais do que corrigem e afogam os últimos alentos da moralização."

O Sistema de Montesinos, como ficou conhecido sua experiência, apresentou peculiaridades na vida prisional, que distinguiram esse modelo espanhol dos outros existentes na Europa e nos Estados Unidos.

Foram estas as características do sistema de Montesinos:

a) Não admitiu o regime celular, porque além de gerar a "mortificação apenado", não permitia a socialização em absoluto isolamento.

b) Influiu eficazmente no espírito dos reclusos com menos castigo e mais autoridade moral.

c) Procurou o equilíbrio entre o exercício da autoridade e a missão pedagógica, com vistas à correção do recluso.

d) Nenhuma sanção disciplinar deveria ter caráter infamante.

e) O poder de disciplina estava em conformidade com o princípio da legalidade, por isso instituiu um Código Interno com regulamento para os presos.

f) Ocupava o preso com o trabalho por ser o melhor instrumento para se conseguir o propósito reabilitador da pena.

g) O trabalho do preso era remunerado para despertar o seu interesse por alguma atividade produtiva.

h) Editou uma prática penitenciária que se constituiu em importante antecedente da prisão aberta, visto que o Presídio de Valência "não possuía um só ferrolho que pudesse resistir ao arrombamento de qualquer apenado", os guardas eram, na maioria, pessoas idosas, pois o mais importante era criar no preso a idéia de que ele deveria ser co-responsável pela segurança do estabelecimento, em respeito aos seus hábitos de subordinação e moralidade.

i) Introduziu no sistema uma espécie de liberdade condicional, reduzindo um terço da condenação como recompensa à boa conduta do preso, apoiado numa interpretação do art. 303 da Ordenação Geral dos Presídios do Reino, de 1834, que lhe serviu de fundamento jurídico. Freqüentemente se atribui a Manuel Montesinos e Molina o pioneirismo pela criação do instituto da liberdade condicional.

j) Estabeleceu a prática da concessão de licenças de saída temporária dos presos. Não se conhecia antes essa iniciativa em nenhum outro Sistema.

1) Considerar benéfica a integração de grupos de presos mais ou menos homogêneos, quer dizer, sem uma rígida separação entre perigosos e não perigosos, não encontrando nenhum inconveniente nessa mesclagem, pois entendia que os "bons" poderiam auxiliar os "maus" no estímulo à modificação do interior humano. 
Manuel Montesinos e Molina foi realmente notável com seu Sistema. Não somente pela visão, mas principalmente pela excelente e inovadora prática prisional, que representou um marco no penitenciarismo da Espanha e do mundo.

Interessante anotar que sua rica experiência com prisão adveio do tempo em que, após a Guerra da Independência, na Espanha, em 1809, foi submetido durante três anos a severo encarceramento em um Arsenal Militar em Tolon, na França.

Em 1854, ele pediu demissão do cargo de Governador do Presídio de Valência. Suas contrariedades resultaram, principalmente, da crise em torno do trabalho do preso.

O regime laborial do Sistema de Montesinos era tão eficiente que os fabricantes e artesãos, em virtude da competição, apresentaram reclamação contra essa concorrência, alegando, inclusive, que a mesma não estava sujeita à onerosa carga de impostos. O Governo atendeu os clamores dos empresários livres e logo a produção na prisão foi diminuindo, perdendo a qualidade, chegando ao ponto de não conseguir matériaprima e sofrer forte campanha publicitária colocando em descrédito o trabalho na prisão.

Sem ajuda do Governo e sem o apoio da comunidade, Manuel Montesinos e Molina deixou o comando do Presídio que, lamentavelmente, a partir daí, se tornou ineficiente no mister de soerguimento social e moral dos apenados.

O estabelecimento do tipo Borstal, implantado para jovens delinquentes, na Inglaterra, em 1902, merece também destaque na trajetória dos Sistemas Penitenciários Clássicos.

A prisão Borstal ficava no Condado de Kent, inaugurada desde 1893 para presos adultos, que lá ficavam em condições pessoais não recomendáveis. Com a reforma, Borstal se transformou em uma prisão para delinquentes, entre 16 e 21 anos, bem adaptada para oferecer instrução moral e profissional aos presos.

O grande avanço do Sistema Borstal foi o pioneirismo no modelo de regime penitenciário aberto na Inglaterra. Isso começou quando, em 1930, um grupo de jovens presos se deslocou para um acampamento na cidade de Nottinghamshire e lá construiu uma moradia para eles e para os que viessem posteriormente. Os próprios presos concebiam a moradia como prisão.

Estava, assim, semeada a primeira casa penal aberta, bem acolhida pela comunidade, tanto que, nos anos posteriores, o próprio Governo apoiou a fixação de outras unidades do Borstal, com o mesmo perfil, para jovens delinquentes, na Inglaterra.

Verifica-se, pelo exposto, a louvável disposição de se conseguir bons resultados pela via da prisão. Não há dúvida de que enorme foi o esforço dos Sistemas Penitenciários Clássicos, no sentido de dotar o modelo de privação de liberdade com crescentes iniciativas, visando aliviar o pesadelo da contínua violação dos direitos humanos nos cárceres e possibilitando, igualmente, a real correção dos delinquentes.

Veja-se que os Sistemas Penitenciários Clássicos serviram de ponte para a orientação do tratamento prisional, desenvolvido no século XX, sob a égide de duas vertentes:

a) individualização científica da pena e de sua execução com métodos de investigação e conhecimento de 
personalidade do preso;

b) administração penal sustentada pelas opções de regime fechado, regime semi-aberto e regime aberto de cumprimento de pena.

Os resultados práticos não geraram as mais produtivas e infalíveis experiências, todavia valeu a contribuição desses Sistemas Clássicos, como ingrediente merecedor de reconhecimento, na luta incessante em busca de prestígio para o processo regenerador que a anormalidade prisional não permite alcançar.

A prisão surgiu no fim do Século XVIII e princípio do Século XIX com o objetivo de servir como peça de punição. A criação de uma nova legislação para definir o poder de punir como uma função geral da sociedade, exercida da forma igual sobre todos os seus membros. Foucault (1987) diz que a prisão se fundamenta na "privação de liberdade", salientando que esta liberdade é um bem pertencente a todos da mesma maneira, perdê-la tem, dessa maneira, o mesmo preço para todos, "melhor que a multa, ela é o castigo", permitindo a quantificação da pena segundo a variável do tempo: "Retirando tempo do condenado, a prisão parece traduzir concretamente a idéia de que a infração lesou, mais alem da vitima a sociedade inteira" (Foucault, 1987, p. 196).

Além disso, a prisão possibilitou a contabilização dos castigos em dias, em meses, em anos se estabeleceu equivalências quantitativas "delito-duração", daí vem à expressão de que a pessoa presa esta pagando sua dívida.

A prisão, como hoje se configura, representa um grande fracasso da justiça penal. Convive-se com denúncias ou constatações que - a não ser pela mudança dos números estatísticos - se repetem desde os primórdios da criação da instituição-prisão: - as prisões não diminuem a taxa de criminalidade, ao contrário tende a aumentá-las; a prisão provoca reincidência; a prisão fabrica delinquientes pelo tipo de existência que os obriga a levarem, como a promiscuidade, imposição de trabalhos inúteis e sem nenhum caráter educativo; abuso de poder, corrupção e incapacidade dos gerenciadores do sistema; favorecimento de organizações criminosas e prontas para cumplicidades futuras; proibições e falta de condições aos egressos para se inserirem na sociedade, fazendo-os retornarem à prisão; desestruturação familiar indiretamente causada pela falta do seu provedor, dentre outras.

Segundo Foucault (2004, p. 223) a resposta às críticas ou colocações acima apontadas tem se repetido:

Há um século e meio que a prisão vem sendo dada como seu próprio remédio; a reativação das técnicas penitenciárias como a única maneira de reparar seu fracasso permanente; a realização do projeto corretivo como o único método para superar a impossibilidade de torná-lo realidade.

Clamar pela ajuda da sociedade para auxiliar na efetivação de mudanças neste quadro tem sido um chamamento muitas das vezes, dirigido ao vazio, pela realidade com a qual se depara, e pela falta de se vislumbrar perspectivas de melhora. $\mathrm{O}$ trabalhador brasileiro, mesmo estando na contingência de trabalhar cerca de quatro meses e meio por ano apenas para estar em dia com seus impostos, vê-se refém da marginalidade, pois a ninguém, até ao indivíduo medianamente informado, escapa à percepção de que as prisões não estão cumprindo o seu papel, isto é, não "recuperam", não "ressocializam" o detento e a "bandidagem" (termo utilizado popularmente) prolifera e está sempre um passo à frente da lei. Depara-se na mídia, ou em outros meios de comunicação com expressões como: "a Cadeia é uma escola do crime" 
"na cadeia o indivíduo entra primário e sai pós-graduado no crime" "bandido bom é bandido morto", e assim por diante.

Tal situação se prolifera com a conivência do Estado, permitindo a perpetuação de uma cultura arcaica. De acordo com Frei Betto (apud Kotscho, 2003, p.41):

O sistema penitenciário, tal como ele existe na sociedade capitalista, principalmente aqui no Brasil, é extremamente cruel, não só porque confina fisicamente o homem, sem que esse homem possa compreender o problema da liberdade, senão em relação à sua locomoção física, mas ele destrói a subjetividade do homem, no sentido de não lhe oferecer nenhuma possibilidade de racionalização da situação em que se encontra.

De acordo com Foucault (1987) a prisão também se fundamenta pelo papel de "aparelho para transformar os indivíduos", servindo desde os primórdios como uma:

[...] detenção legal [...] encarregada de um suplemento corretivo, ou ainda uma empresa de modificação dos indivíduos que a privação de liberdade permite fazer funcionar no sistema legal. Em suma o encarceramento penal, desde o início do século XIX, recobriu ao mesmo tempo a privação de liberdade e a transformação técnica dos indivíduos".

A história do sistema penitenciário no Brasil revela que, desde o início, a prisão foi local de exclusão social e questão relegada a segundo plano pelas políticas públicas, importando, conseqüentemente, a falta de construção ou a edificação inadequada dos edifícios penitenciários, na maioria das vezes improvisados.

Estabelecia o Livro V das Ordenações Filipinas do Reino, Código de leis portuguesas que foi implantado no Brasil durante o período Colonial que "decretava a Colônia como presídio de degredados" A pena era aplicada aos alcoviteiros, culpados de ferimentos por arma de fogo, duelo, entrada violenta ou tentativa de entrada em casa alheia, resistência a ordens judiciais, falsificação de documentos, contrabando de pedras e metais preciosos.

A utilização do território colonial como local de cumprimento das penas se estende até 1808, ano marcado por mudanças significativas rumo à autonomia legal e aos anseios de modernidade, tão em voga naqueles tempos, segundo assinala Pedroso.

A instalação da primeira prisão brasileira é mencionada na Carta Régia de 1769, que manda estabelecer uma Casa de Correção no Rio de Janeiro.

Registra-se, também, a Cadeia construída na cidade de São Paulo entre 1784 e 1788, conhecida simplesmente como Cadeia e estava localizado no então Largo de São Gonçalo, hoje Praça João Mendes. Era um grande casarão assobrado, onde funcionava também a Câmara Municipal. Na parte inferior, existiam as salas destinadas à prisão e, no piso superior, os espaços para as atividades da Câmara. Para lá eram recolhidos todos os indivíduos que cometiam infrações, inclusive escravos, e era onde aguardavam a determinação de penas como o açoite, a multa e o degredo; uma vez que não existia, ainda, a pena de prisão.

A Constituição de 1824 estabelecia, no art. 179, que as prisões deveriam ser seguras, limpas, arejadas, havendo a separação dos réus conforme a natureza de seus crimes. 
O Código Criminal de 1830 estabeleceu a pena de prisão com trabalho para vários crimes, implicando a construção de Casas de Correção com celas individuais e oficinas de trabalho e uma arquitetura própria para a pena de prisão. O café e a industrialização proporcionavam um estímulo cada vez maior para o crescimento populacional e também econômico do país, mas as casas de recolhimento de presos do início do século XIX mostravam condições deprimentes para o cumprimento da pena por parte do detento, inclusive local onde se recolhiam escravos, menores e loucos.

O Código Penal de 1890 estabeleceu novas modalidades de penas: prisão celular, banimento, reclusão, prisão com trabalho obrigatório, prisão disciplinar, interdição, suspeição e perda do emprego público e multa. O artigo 44 do Código considerava que não haveria penas perpétuas e coletivas. As penas restritivas de liberdade individual eram temporárias e não deveriam exceder trinta anos, eram elas: prisão celular, reclusão, prisão com trabalho obrigatório e prisão disciplinar.

A prisão celular, inspirada no modelo pensilvânico e de Roquete foi a grande novidade da revisão penal de 1890 e foi considerada punição moderna, base arquitetural de todas as penitenciárias.

No entanto, o aumento gradativo e constante da população carcerária confrontou-se com as limitações de espaço das prisões, inviabilizando o direito à cela individual.

No interior do país o problema alcançou dimensões grandiosas e por muitos anos e que nem o Código Penal de 1940 conseguiu apaziguar, segundo assinala Brito,

dada a insuficiência das prisões municipais onde se acumulam, entre paredes e grades, homens de todas as condições sociais, e até menores, mulheres e loucos. E o que mais chocante é, muitas delas de fachadas modernizadas, por exigências de urbanismo, mas cujo interior vale por um excárneo e por um contraste desalentador do que se mostra fora (Brito, 1947, p. 442).

Registra-se que no século XIX já existia uma sociedade para melhoria das prisões, um movimento para torná-la mais eficaz.

No século XX, começaram os primeiros estudos para a elaboração de uma legislação penitenciária, conforme ressalta Barbosa (1993, p. 87), mencionando que em 1937 elaborou-se o Projeto de Código Penitenciário pelos juristas Cândido Mendes, Lemos Brito e Heitor Carvalho, enquanto em 1957, outro Anteprojeto de Código Penitenciário foi elaborado por Oscar Stevenson e em 1963, o Professor Roberto Lyra elaborou o Anteprojeto de Código de Execuções Penais.

No entanto, nenhum destes Anteprojetos vingou vindo a ser promulgada em 1984 a Lei n $^{\circ} 7.210$, que estabeleceu sobre a execução penal, fruto de comissão nomeada pelo então Deputado Abi-Ackel, marco do Direito Penitenciário no país.

O crime não é apenas uma questão de não educação, mas também de muitos outros fatores que fazem parte de nossa realidade, entretanto, podemos adequar esta sua afirmativa à questão do condenado à pena privativa de liberdade, afirmando que o meio mais seguro de tornar o homem menos inclinado a reincidir no crime é respeitando os seus direitos como cidadão e ser humano que é.

A Lei de Execução Penal diz que o preso, tanto o que ainda está respondendo ao processo, quanto o 
condenado, continua tendo todos os direitos que não lhes foram retirados pela pena ou pela lei.

Significa, portanto, que o preso ao receber sua condenação, perde a liberdade, mas não seu direito a um tratamento digno, sem violência física ou moral.

É senso comum que a violência somente gera violência. Faz parte da natureza humana comportar-se de forma hostil em um ambiente destrutivo, até como forma de integrar o indivíduo ao meio em que vive. A violência, infelizmente, está hoje institucionalizada em decorrência de uma estrutura mantida a força, que privilegiam poucos, em prejuízo de muitos. Hodiernamente é o fenômeno social que mais preocupa a sociedade. Por outro lado também é questão de preocupação a violência oficial que se revela na inexistência de uma política carcerária eficaz e reeducadora.

O modelo de sociedade em que hoje vivemos não valoriza a condição humana e por esse motivo acaba tornando-se também fato gerador de violência. A falta de percepção deste fenômeno social é campo fértil às idéias fáceis e bem acolhidas pela sociedade. Há os que defendem o endurecimento da lei e que colocam as ideologias humanistas e os defensores dos direitos humanos como elementos contrários ao combate da criminalidade. Acusam os organismos humanitários de desconsiderarem o lado da vítima, porém somente apresentam como proposta para atenuar o sofrimento dos vitimados a subjugação do ofensor.

As prisões que surgiram como forma de humanização das penas na verdade acabou por se tornar um depósito de lixo humano. A pena continua a ser encarada por todos como mero ato de vingança. Muitos até entendem que a situação ideal seria torná-la até mais rigorosa.

Verificamos, assim, que a estrutura do sistema carcerário está voltada unicamente para o castigo, quanto aos direitos do preso descritos na Lei de Execuções Penais, de 1.984, e normativos como a Constituição Federal e demais tratados sobre direitos humanos são reiteradamente descumpridos. Há de se convir, entretanto, que não é nada inteligente manter uma pessoa presa por longo período, submetendo-a a toda espécie de desrespeito ao ser humano que é, para depois "libertá-la", fazendo com que a sociedade experimente o resultado de sua criação. Algo deve ser feito, ainda no curso do cumprimento da pena, para tentar devolver a pessoa ao convívio social munida de valores que não a façam enveredar pelo caminho da reincidência.

Ao reiterar sistematicamente que os Direitos Humanos só servem para proteger bandidos, acaba por ser aceito como verdadeiro, quando, na realidade, é fruto de profunda ignorância e acarreta, em nosso meio, a fragilização de conquistas democráticas que a humanidade levou séculos para firmar. Na verdade, os Direitos Humanos existem para quem deles precisa, e, por não serem excludentes, acabam alcançando também àqueles que um dia os violaram. Os presos em nosso país são vítimas de incessantes afrontas aos Direitos Humanos. As condições de nossas cadeias e penitenciárias, já de todos conhecidas, transformam as penas privativas de liberdade em medidas de extrema crueldade. $\mathrm{O}$ grau de violência contra acusados de praticar um crime parece ser aceito socialmente ou mesmo encorajado. O conceito de Direitos Humanos é tido como forma de proteção a criminosos e a necessidade de acalmar a sensação generalizada de insegurança pública alimenta o desejo da população por medidas mais fortes e mais repressivas contra suspeitos de terem cometido crimes.

As regras mínimas da ONU sobre tratamento de presos soam como piada para nós. Os Tratados 
Internacionais de Direitos Humanos, dos quais nosso País é signatário, são solenemente ignorados. Descumprimos, reiteradamente, a Lei de Execuções Penais em inúmeros dispositivos, com destaque, é óbvio, para os que dispõem sobre os direitos do preso.

Se acreditássemos que os rigores positivados da pena e da execução fossem instrumentos eficazes no combate à violência e à criminalidade, teríamos resolvido alguns de nossos mais terríveis problemas. $\mathrm{Na}$ verdade, a violência e a criminalidade são, na realidade, filhas das injustiças sociais.

É remota a ideia de que os presos não têm direito algum. O condenado é amaldiçoado e, sofrendo a pena, é objeto da máxima censura da coletividade, que o priva de toda a proteção do ordenamento jurídico que ousou violar. O criminoso é desprezível e vil, servo da pena, perde a paz e está fora do direito. É necessário entender que, por força da nossa ordem jurídica positivada, o encarcerado não perde a cidadania, é sujeito de direitos na execução. Ele é titular, ainda, de todo o rol de direitos fundamentais previstos na Constituição que sejam compatíveis com a situação em que se encontra. Qualquer medida restritiva de sua liberdade deve vir prevista em lei, ser proporcional à pena atribuída ou virtualmente projetada, preservando-se sempre a liberdade jurídica residual que não foi tocada pela sentença condenatória.

A perda ou restrição provisória da liberdade não acarretam a supressão de direitos fundamentais. O crime não retira do homem sua dignidade. O indivíduo, por mais vil que possa parecer, é sempre sujeito de direitos.

Apesar de a Constituição Federal prever no seu artigo 5, inciso XLIX, do Capítulo dos Direitos e Garantias Fundamentais, que "é assegurado aos presos o respeito à integridade física e moral", o Estado continua fracassando nas prerrogativas mínimas de custódia. À incapacidade de gerenciamento do Estado some-se a incompetência do modelo prisional vigente para a recuperação dos presos. $\mathrm{O}$ resultado desta mistura é um local onde não existem as mínimas condições de respeito aos direitos humanos. E sem respeito à pessoa humana, como a garantia da dignidade e da integridade física, o que se produz a cada dia são pessoas desprovidas de humanidade.

O preso não só tem deveres a cumprir, mas é sujeito de direitos, que devem ser reconhecidos e amparados pelo Estado. O recluso não está fora do direito, pois se encontra numa relação jurídica em face do Estado, e, exceto os direitos perdidos e limitados a sua condenação, sua condição jurídica é igual à das pessoas não condenadas.

Denota-se que muito embora tenhamos em nosso ordenamento pátrio dispositivo legal que visa garantir a integridade física do condenado e o respeito à sua dignidade humana, infelizmente parecem estarem esquecidos. Falta na realidade, vontade política e seriedade na administração pública com atitudes sérias, a fim de mudar a situação caótica que chegou hoje nosso sistema prisional, porém, há que se ter em mente que somente teremos solução quando nossos planos de segurança forem planejados com serenidade e não no calor de crises visando apenas saciar os anseios da sociedade.

A verdade é que apenas se tem procurado oferecer soluções para os efeitos, esquecendo-se que o problema está a exigir remédios heroicos para as causas. Se atacarmos os efeitos, as causas persistirão e as conseqüências crescerão numa razão geométrica. 
Tendo a pena privativa de liberdade o objetivo não apenas de afastar o criminoso da sociedade, mas, sobretudo, de excluí-lo com a finalidade de ressocializá-lo, note-se que a pena de prisão atinge o objetivo exatamente inverso: ao adentrar no presídio, o apenado assume o seu papel social de um ser marginalizado, adquirindo as atitudes de um preso habitual e desenvolvendo cada vez mais a tendência criminosa, ao invés de anulá-la.

É preciso a transformação do sistema para que a reforma do condenado seja propiciada por instrumentos como a educação e o trabalho, de modo a dar-lhe condições de levar uma vida digna quando sair do estabelecimento prisional, e evitar que o cárcere seja mais penoso do que deve ser.

A intenção, então, é buscar alternativas para sancionar os criminosos, que não os isolar socialmente. Isto porque a pena de prisão determina a perda da liberdade e da igualdade, que derivam da dignidade humana. E a perda dos direitos fundamentais de liberdade e igualdade representa a degradação da pessoa humana, assim como a tortura e o tratamento desumano, que hoje são expressamente proibidos pela Constituição Federal.

Por mais que se pretenda que a pena privativa de liberdade deva preparar o sujeito para a vida livre, o certo é que propicia a formação de uma sociedade antinatural, na qual o sujeito carece das motivações da sociedade livre, adquirindo características rudes e primitivas, que costumam persistir após a recuperação da liberdade, e, que ao entrar em conflito com a sociedade livre, têm a oportunidade de manifestar-se.

A ideia dos direitos do preso tem origem bem recente. Decorre da consequiência lógica de se considerar a privação de liberdade como uma medida extremada, cujos limites devem ser estabelecidos, e que, em definitivo, é reforçado pela comprovação de que é um mal, para o qual ainda não se encontrou substituto, e, nem mesmo parece existirem esforços sérios para reduzi-lo, pelo menos em nosso país.

Nossa Lei de Execução Penal não passa de uma "carta de intenção".

A falta de infra-estrutura e o total descaso dos nossos governantes tem contribuído de forma significativa para a transformação das penitenciárias brasileiras em verdadeiras "escolas do crime". Se por um lado, os maus tratos, as celas lotadas, as condições precárias, a falta de alimentação adequada e o meio insalubre trazem o arrependimento do preso pelo crime cometido, por outro, também trazem a revolta.

Além disso, a falta de um acompanhamento psiquiátrico e a não utilização de atividades intelectuais e esportivas acabam por arruinar a integridade física e moral do apenado, propiciando dessa forma ao cultivo de pensamentos perversos e banais, não contribuindo de forma alguma a sua reabilitação, pelo contrário, prejudicando-o ainda mais.

Como se não bastasse, quando o delinquente readquire a liberdade, depara-se com os obstáculos impostos por uma sociedade preconceituosa e excludente que não consegue enxergá-lo como um indivíduo normal (isso no caso de ele ter sido realmente recuperado), aplicando-lhe outras sanções igualmente severas, que é a falta de oportunidade no mercado de trabalho, o desemprego, a falta de cidadania básica, etc. Diante do exposto, a única alternativa é voltar a cometer os mesmos crimes, a fim de que possa sobreviver.

Em 1991, O Instituto da UNESCO para a Educação (IUE), lançou um projeto para investigar e promover a educação nas prisões tendo como público alvo os adultos sentenciados e encarcerados. Umas das metas 
do projeto consistia em contribuir para o desenvolvimento do potencial humano que se restringia devido às desvantagens sociais. Os objetivos principais do projeto eram identificar estratégias bem sucedidas da educação básica nos contextos prisionais, de modo a dar a elas visibilidade, condições de refinamento e replicabilidade.

O relatório da UNESCO (1993: p. 60) indica que os prisioneiros são geralmente jovens, entre 18 a 25 anos. A maioria é constituída por homens, e a presença feminina nas prisões varia entre $2 \%$ e $7 \%$ da população total prisional. A mulher é uma minoria na prisão, tanto em número quanto em visibilidade. As recomendações de estudos prisionais indicam a necessidade de não continuar ignorando s necessidades de perfil prisional das mulheres apenadas. Em muitos momentos, as dificuldades das mulheres são as mesmas dos homens (o ambiente, o sistema, a superpopulação, etc.), entretanto existem questões específicas que precisam ser observadas (a situação dos filhos, a gravidez, o emocional, as necessidades, as habilidades, etc).

$\mathrm{Na}$ esfera internacional, a educação prisional de qualidade e apropriada ao contexto em sido vista como uma parte obrigatória e essencial nas atividades de reabilitação prisional. Entre as pesquisas que procuram esclarecer o perfil do universo prisional destaca-se a publicação da UNESCO - Instituto para a Educação denominada "Educação Básica nas Prisões" (1995). O documento oferece fundamentação, conceitos e relatos globalizados procurando resgatar iniciativas educacionais, a elucidação de contextos prisionais em diferentes culturas seguindo uma perspectiva de educação vitalícia e de direitos humanos.

\section{A FALTA DE ACESSO À EDUCAÇÃO PRISIONAL}

O direito à educação escolar como "condição ineliminável de uma real liberdade de formação (desenvolvimento da personalidade) e instrumento indispensável da própria emancipação (progresso social e participação democrática) " é um direito humano essencial para a realização da liberdade e para que esta seja utilizada em prol do bem comum. Desta forma, ao abordarmos a educação nas prisões é importante ter claro que os reclusos, embora privados de liberdade, mantêm a titularidade dos demais direitos fundamentais. $\mathrm{O}$ acesso ao direito à educação do recluso deve ser assegurado universalmente, a todos e todas, dentro da perspectiva acima delineada e em respeito às normas que o asseguram.

Em âmbito internacional, as "Regras mínimas para o tratamento de prisioneiros", elaborado no $1^{\circ}$ Congresso das Nações Unidas sobre Prevenção do Crime e Tratamento de Delinquentes, realizado em Genebra, em 1955, estabeleceu uma garantia específica à educação nas prisões. Em que pese este documento ser um marco na garantia do direito à educação das pessoas presas, as orientações previstas neste são restritivas, e não afirmam o caráter universal deste direito.

Em documentos internacionais mais recentes, tal como Declaração de Hamburgo, de 1997, a abordagem do direito à educação de pessoas presas avançou, afirmando-se expressamente na Declaração a "preocupação de estimular oportunidades de aprendizagem a todos, em particular, os marginalizados e excluídos" (item 11) e no "Plano de Ação para o futuro", aprovado neste encontro, no item 47, o reconhecimento do direito de todas as pessoas encarceradas à aprendizagem: a) proporcionando a todos os presos informação sobre os diferentes níveis de ensino e formação, e permitindo-lhes acesso aos mesmos; b) elaborando e implementando nas prisões programas de educação geral com a participação dos presos, a fim de responder a suas necessidades e aspirações em matéria de aprendizagem; c) facilitando que organizações não-governamentais, professores e outros responsáveis por atividades educativas 
trabalhem nas prisões, possibilitando assim o acesso das pessoas encarceradas aos estabelecimentos docentes e fomentando iniciativas para conectar os cursos oferecidos na prisão aos realizados fora dela. (Declaração de Hamburgo, 1997, tema 8, item 47)".

No Brasil, a Lei de Diretrizes e Bases da Educação (L. 9394/96, que estabelece parâmetros dos níveis e modalidades de ensino no país) não traz nenhuma referência à educação de jovens e adultos presos. A abordagem específica da educação nas prisões foi estabelecida na Lei de Execução Penal - LEP (L. 7210/84).

Neste documento, a assistência educacional do preso é expressamente prevista como um direito no inciso VII, do artigo 41. Contudo, ao especificar nos artigos 17 a 21 (conferir nota) como se dará a assistência educacional, observa-se certa restrição às oportunidades educacionais nos presídios se comparada à educação fornecida aos jovens e adultos que não se encontram no sistema prisional: apenas o $1^{\circ}$ grau (ensino fundamental) foi previsto como obrigatório, não sendo prevista a possibilidade de acesso ao ensino médio ou superior para os detentos que cumprem pena em regime fechado (que não pode sair da prisão), o que viola normas constitucionais que postulam como dever do estado a "progressiva universalização do ensino médio gratuito" (artigo 208, inciso II) e o "acesso aos níveis mais elevados do ensino, da pesquisa e da criação artística, segundo a capacidade de cada um" (artigo 208, inciso V).

Além disto, nos artigos da LEP é possível identificar uma forte valorização do trabalho em detrimento ao direito à educação: o artigo 126 assegura a remição penal através do trabalho, mas não garante à educação o mesmo benefício. Esta valorização do trabalho frente à educação, além de não incentivar a procura por escolarização, reforça a sua descaracterização como um direito, colocando a educação formal como um privilégio, um plus concedido aos detentos.

Neste tema, é também relevante apontar que hoje é matéria de discussão no Congresso Nacional a remição da pena pela educação (Projeto de Lei 5189/05). Este pode ser um importante passo para o fortalecimento e universalização do direito à educação nas prisões, segmento tão marginalizado e discriminado em nossa sociedade.

A valorização do direito ao trabalho frente à educação traz também como consequiência um maior estímulo à educação como mecanismo de acesso e preparo para o mercado de trabalho, em detrimento de outros objetivos do direito à educação, como desenvolvimento pessoal ou a formação para a cidadania. Além da LEP, a educação nas prisões foi também abordada no Plano Nacional de Educação e no Plano Nacional de Educação em Direitos Humanos.

O Plano Nacional de Educação estabeleceu em sua $17^{\mathrm{a}}$ meta que, no período de 10 anos, os poderes públicos deverão: "Implantar, em todas as unidades prisionais e nos estabelecimentos que atendam adolescentes e jovens infratores, programas de educação de jovens e adultos de nível fundamental e médio, assim como de formação profissional, contemplando para esta clientela as metas $\mathrm{n}^{\circ} 5$ (financiamento pelo o MEC de material didático-pedagógico) e n ${ }^{\circ} 14$ (oferta de programas de educação à distância)".

Já no Plano Nacional de Educação em Direitos Humanos, a meta 26 determina que os Poderes Públicos deverão: "apoiar a elaboração e a implementação de programas para assegurar a educação básica nos sistemas penitenciários".

De maneira geral, as normas referentes à educação penitenciária deixam margem a interpretações 
ambíguas, tanto na afirmação do direito educativo, como em relação à responsabilidade por sua implementação. Os textos fazem insistentes referências à parceria entre Estado e sociedade civil.

Se, de um lado isto pode ser positivo, uma vez que possibilita o controle social sobre o ambiente prisional, geralmente fechado em rígidas estruturas hierárquicas; de outro tende a estimular a transferência da responsabilidade do Estado para as organizações civis, muitas vezes impossibilitando a correlação com o sistema de ensino oficial.

As pessoas privadas de liberdade constituem um dos grupos severamente marginalizados que estão submetidos à violação endêmica de seu direito a educação.

Dos 440 mil presos no Brasil, 75\% não completaram a educação básica e 12\% são analfabetos. Apenas $18 \%$ dos detentos têm acesso a alguma atividade educacional ainda assim, incluindo cursos como o de violão. Esses dados, colhidos entre setembro de 2008 e fevereiro de 2009, constam do relatório preliminar sobre a situação da educação nas prisões brasileiras apresentadas junto à Comissão de Educação e Cultura pela relatora brasileira da Organização das Nações Unidas (ONU) para o Direito Humano à Educação, Denise Carreira.

De acordo com o relatório, além de a educação ser vista como um privilégio pelo sistema prisional, o processo educacional não é contínuo: basta haver qualquer tumulto no presídio para ser interrompido.

As condições de estudo são precárias: faltam salas de aula e os espaços que poderiam ser aproveitados são adaptados para funcionar como celas. Além disso, os professores enfrentam a desconfiança dos agentes penitenciários, que interferem no conteúdo. "O contato físico, como aperto de mãos, é cerceado. Professoras já foram afastadas sob acusação de envolvimento sentimental com detentos", disse a relatora.

Outro problema apontado pelo relatório é o conflito entre horário de trabalho e estudo. Quem trabalha segundo Denise, dificilmente vai encontrar tempo para estudar. E, como a demanda é maior do que a oferta é feita triagem por bom comportamento.

O controle "extremo" do acesso ao papel se constitui outro grave problema. Além disso, materiais escolares são destruídos em busca de drogas.

A educação é um direito social assegurado pela Constituição Federal e consagrado na legislação internacional. No entanto, quando se trata da população encarcerada, tal direito parece não ter o mesmo grau de reconhecimento. Se é fato que as camadas pobres da população são privadas de vários direitos, entre eles, o direito a uma educação de qualidade, essa realidade torna-se ainda mais contundente e pior mais invisível ou naturalizada - em se tratando de pessoas condenadas pelo sistema de justiça penal. No Brasil, em muitas instituições penais, a oferta de serviços educacionais é inexistente, insuficiente ou extremamente precária, o que se soma a regimes disciplinares e legais que não incentivam ou mesmo inviabilizam o engajamento de pessoas presas em processos educacionais.

Nos últimos anos, observa-se em escala mundial a perda do ideal reabilitador das prisões, concomitante a um recrudescimento das políticas de segurança pública, o que resulta em ampliação da população presa e no abandono das medidas ditas ressocializadoras no interior dos sistemas penitenciários.

As pessoas com discapacidades ou dificuldades para a aprendizagem tornam-se objeto de estigmatização 
e discriminação em particular com respeito à educação dos sistemas penitenciários que sistematicamente não reconhecem, não entendem e nem apoiam as necessidades concretas dessas pessoas e as tornam cada vez mais vulneráveis.

Ocorre que em muitos sistemas penitenciários não se reconhece o fato de que entre os reclusos existem pessoas com discapacidades ou dificuldades para a aprendizagem cuja proporção estimada oscila entre 20 e $30 \%$ chegando até mesmo a $52 \%$ da população carcerária. Conseqüentemente, não se adota com respeito a essas pessoas nenhuma disposição especial. Apesar da complexidade e necessidades extremamente diversas que requerem a cooperação entre serviços. Finalmente, ainda não há nenhuma certeza, eficácia ou resultados dos programas da natureza geral ou específica disponível nas cadeias para os reclusos com discapacidades ou dificuldades para a aprendizagem.

A educação pode ser considerada, entretanto, um caminho promissor para a reintegração social da pessoa condenada à pena de prisão. Mas, além disso, e antes

de tudo, é um direito humano universal que deve ser assegurado a todas as pessoas, independentemente de sua situação; é um direito que, ademais, potencializa o exercício de outros direitos como o trabalho, a saúde e a participação cidadã. A extensão dos serviços de educação a grupos historicamente marginalizados - como as pessoas privadas de liberdade - é, portanto, parte essencial na luta pela afirmação dos Direitos Humanos em sua universalidade. Os poucos dados existentes a respeito da escolaridade das pessoas presas no Brasil apontam que, apesar de mais de 70\% delas não terem concluído o ensino fundamental e de $10,5 \%$ serem analfabetas, apenas $17 \%$ estudam. Os números, bastante eloqüientes, mostram que é urgente a mobilização dos órgãos governamentais e da sociedade civil para que se cumpra no Brasil a Constituição, que garante a todos os brasileiros, independentemente da idade, o direito ao ensino fundamental e obriga o Estado a ofertá-lo, assim como a Lei de Execução

Penal, que garante ao preso o direito ao estudo.

O Estado de São Paulo concentra metade da população encarcerada do país e, nos últimos anos, assistiu à escalada da superpopulação, desumanização e desgoverno das instituições penitenciárias. Nesse sentido, não é apenas pertinente, mas urgente a formação de um grupo de trabalho permanente sobre educação nas prisões, para reunir e potencializar os esforços de pessoas e instituições dedicadas à promoção dos direitos humanos das pessoas presas e dos direitos educativos.

Uma antiga máxima popular diz que "mente vazia é a oficina do diabo". Este provérbio não poderia ser mais adequado quando se trata da vida carcerária. O indivíduo privado de sua liberdade e que não encontra ocupação, entra num estado mental onde sua única perspectiva é fugir. O homem nasceu para ser livre, não faz parte de sua natureza permanecer enjaulado. Algumas raríssimas cadeias ainda oferecem certas condições que superam a qualidade de vida do preso se estivesse do lado de fora. Ainda assim, o sentimento de liberdade sempre é maior e mesmo estas cadeias acabam vivenciando rebeliões de fuga. Preso que não ocupa seu dia, principalmente sua mente, é um maquinador de idéias, a maioria delas, ruins.

O presídio é um sistema fechado onde o encarcerado é obrigado a conviver, permanentemente, com outros indivíduos, alguns de índole igual, melhor ou pior. Nem sempre há cordialidade e animosidade é algo comum, gerando um eterno clima de medo e preocupação constantes, pois o preso nunca sabe se "o 
seu dia vai chegar". Grande parte desta angústia vivida pelo presidiário advém da falta de ocupação, de uma atividade que ocupe seu tempo, distraia sua atenção e que o motive a esperar um amanhã melhor. A idéia de todo presidiário é que sua vida acabou dentro das paredes da cadeia e que não lhe resta mais nada. Amparo psicológico é fundamental, pois nenhum ser humano vive sem motivação. Presídio sem ocupação se torna uma escola "às avessas": uma formadora de criminosos mais perigosos.

Por não ter um estudo ou ocupação, conseqüentemente, carecer de um senso moral que a vida pré-egressa não conseguiu lhe transmitir, a personalidade do preso passa a sofrer um desajuste ainda maior. Sua única saída é relacionar-se com os demais presos e intercambiar com ele suas aspirações, valores e visões de mundo, quase sempre distorcidas. Passa a adquirir novos hábitos, que antes não tinha, enfim transformase num indivíduo pior do que quando entrou. Além disso, distúrbios psicológicos que já possuía antes de vir para o presídio se agravam, justamente por se ver inserido num novo contexto social, repleto de hostilidades e desrespeito.

A grande maioria dos indivíduos presos não tiveram melhores oportunidades ao longo de suas vidas, principalmente a chance de estudar para garantir um futuro melhor. Nesse sentido, o tempo que despenderá atrás das grades pode e deve ser utilizado para lhe garantir estas oportunidades que nunca teve, por meio de estudo e, paralelamente, de trabalho profissionalizante. Além de ajeitar as celas, lavar corredores, limpar banheiros etc., os detentos precisam ter a chance de demonstrarem valores que, muitas vezes, encontram-se obscurecidos pelo estigma do crime.

Existem casos de detentos que demonstram dotes artísticos, muitos deles se revelando excelentes pintores de quadros e painéis de parede, além de habilidades com esculturas, montagens, modelagens, marcenaria etc. Também, decoram as celas de acordo com sua criatividade e sua personalidade. Estas artes devem ser incentivadas, pois é uma forma de ocupar o preso, distraindo-o e aumentando sua auto-estima. É a chance de mostrar a ele de que existe a esperança de um amanhã melhor além das grades que o separam do mundo exterior.

A visão à cerca do criminoso é que, a partir do delito ele se torna um indivíduo à parte na sociedade, e que seu isolamento dentro de uma prisão significa a perda de toda a sua dignidade humana devendo, por isso, ser esquecido enquanto pessoa humana, e ignora-se que os direitos humanos valem para todos, sejam criminosos ou não. Infelizmente, no Brasil, a vida de pessoas pobres ou criminosas tem menos valor.

As escolas prisionais brasileiras não possuem vagas suficientes para atender à procura por educação e os detentos que freqüentam os cursos têm um ensino desvinculado da proposta de ressocialização do sistema penal. A oferta de ensino fundamental e médio em penitenciárias brasileiras é, de modo geral, limitada.

Apesar da ênfase que teoricamente se dá a ressocialização, não consta do currículo escolar adotado nas cadeias uma matéria específica, destinada a atingir esse objetivo. Não existe algo curricular exclusivo para a situação; o conteúdo das disciplinas ministradas é o mesmo adotado nas escolas regulares.

A Constituição Federal Brasileira de 1988 no artigo 205 e a Lei de Diretrizes e Bases da Educação Nacional 9394/96 no artigo $2^{\circ}$ garantem a educação como um direito de todo cidadão e um dever do Estado. No entanto, os efeitos excludentes das políticas econômicas, causam déficits educacionais e culturais, como podem ser contemplados no censo 2007 onde estão registrados percentuais elevados de jovens e adultos analfabetos liberais e funcionais, bem como, a não conclusão do Ensino Fundamental, o 
Ensino Médio e muito menos a Educação Superior.

\subsection{AS REALIDADES DO SISTEMA PRISIONAL BRASILEIRO}

O sistema prisional brasileiro abriga 469 mil detentos, mas o número de vagas disponíveis no país é suficiente para 299 mil presos. O déficit é de aproximadamente 170 mil vagas. Os dados fazem parte do levantamento feito pelo Departamento Penitenciário Nacional (Depen), finalizado em 30 de junho 2009, e que inclui os 60 mil presos em delegacias de polícia do país.

Segundo o Ministério da Justiça, o país tem 1.771 estabelecimentos no sistema penitenciário, sendo que 1.172 estão sob coordenação das secretarias de Justiça dos estados. O restante está sob coordenação das secretarias de Segurança Pública.

O Depen informou que é difícil quantificar a população carcerária do país, porque há estados que não repassam as informações sobre o número de detentos no sistema e nem mesmo as vagas disponíveis.

Airton Aloísio Michels, diretor do Depen, disse que não vê perspectivas para que o sistema penitenciário do país consiga alcançar a demanda de vagas. "O país teria de construir milhares de presídios e ainda reservar vagas para contemplar os possíveis condenados pela Justiça."

O diretor disse ainda que os presídios do país estão em situação caótica. "É uma vergonha. Não há recuperação do indivíduo. As penitenciárias federais de segurança máxima não têm esse objetivo de ressocialização, mas estão longe de sofrerem superlotação". A unidade de Catanduvas (PR) tem 145 presos atualmente. Em Campo Grande, a penitenciária abriga outros 140 detentos e, em Porto Velho (RO), estão 39 homens.

O Conselho Nacional de Justiça (CNJ), com apoio dos tribunais de Justiça dos estados, realiza uma série de mutirões nas carceragens do país, na tentativa de verificar a situação dos detentos e fazer uma reavaliação dos processos criminais.

A ação, que conta com juízes, promotores, defensores públicos e servidores do Judiciário, já colocou em liberdade presos da Bahia, Amazonas, Ceará, Paraíba, Pernambuco, Mato Grosso do Sul, Goiás e Espírito Santo.

Um em cada três presos está em situação irregular, ou seja, deveriam estar em presídios, mas encontramse confinados em delegacias ou em cadeias públicas.

De acordo com dados obtidos junto ao Departamento Penitenciário Nacional, o sistema carcerário no Brasil se divide em algumas categorias: penitenciárias, presídios, cadeias públicas, cadeiões, casas de detenção e distritos ou delegacias policiais, colônias agrícolas entre outras, vejamos algumas delas:

Cadeias Públicas: destinam-se ao recolhimento de presos provisórios;

Penitenciárias: destinam-se ao condenado à pena de reclusão, em regime fechado;

Penitenciárias de Segurança Máxima Especial: estabelecimentos penais destinados a abrigar pessoas presas com condenação em regime fechado, dotados exclusivamente de celas individuais; 
Penitenciárias de Segurança Média ou Máxima: estabelecimentos penais destinados a abrigar pessoas presas com condenação em regime fechado, dotados de celas individuais e coletivas;

Colônias Agrícolas, Industriais ou Similares: destinam-se ao cumprimento da pena em regime semiaberto;

Casas do Albergado: destinam-se ao cumprimento de pena privativa de liberdade, em regime aberto, e da pena de limitação de fim de semana;

Centros de Observação Criminológica (COP): destinam-se a realização de exames gerais e criminológicos, cujos resultados serão encaminhados à Comissão Técnica de Classificação, ou seja, tem por objetivo a análise dos aspectos de saúde física, psicológica, psiquiátrica, realização de exame criminológico para a determinação do tratamento individualizado, tendo como base levantamentos dos aspectos sociais, econômicos e suas vocações profissionais, além da situação jurídica do detento;

Hospitais de Custódia e Tratamento Psiquiátrico: destinam-se aos inimputáveis e semi-imputáveis referidos no artigo 26 e seu parágrafo único do Código Penal, onde serão realizados os exames psiquiátricos e os demais exames necessários ao tratamento para todos os internados;

Delegacia ou Distrito Policial: uma unidade policial fixa para o atendimento ao público, base e administração de operações policiais, investigações criminais e detenção temporária;

Cadeiões: unidades de segurança máxima onde os internos passam o dia inteiro preso, destinado aos jovens infratores.

Estas divisões em categorias de estabelecimentos servem para que cada preso seja identificado por características e encaminhado para o local adequado. No entanto, na prática, essas categorias não funcionam a risca, uma vez que muitos dos presos são deslocados de um estabelecimento para outro.

Tabela 01 - _Dados Consolidados do Ministério da Justiça, em 2006.

\begin{tabular}{|c|c|c|}
\hline Regime fechado & Regime semi-aberto & Regime aberto \\
\hline Homens: 154.861 & Homens: 39.575 & Homens: 16.704 \\
\hline Mulheres: 8.944 & Mulheres: 2.156 & Homens: 1.607 \\
\hline Total: $\mathbf{1 6 3 . 8 0 5}$ & Total: $\mathbf{4 1 . 7 3 1}$ & Total: $\mathbf{1 8 . 3 1 1}$ \\
\hline
\end{tabular}

\begin{tabular}{|c|c|}
\hline Provisório & Medida de Segurança \\
\hline Homens: 107.968 & Homens: 3.256 \\
\hline Mulheres: 4.170 & Mulheres: 339 \\
\hline Total: 112.138 & Total: $\mathbf{3 . 5 9 5}$ \\
\hline
\end{tabular}


- Total de estabelecimentos: $\mathbf{0 5 1}$

- População do sistema penitenciário: $\mathbf{3 3 9 . 5 8 0}$

- Vagas do sistema penitenciário: 236.148

- Secretaria de Segurança Pública: 61.656

- População prisional do Brasil: 401.236

As superlotações, os envolvimentos de presos em organizações criminosas e a falha de pessoal, são os principais problemas enfrentados pelas penitenciárias brasileiras. Outro fator que estamos acostumados a ver nos noticiários é a questão das rebeliões em presídios, sempre com resultados lastimáveis de sentenciados que são mortos por seus próprios companheiros, funcionários e familiares de detentos transformados em reféns, resgates e fugas audaciosas e espetaculares realizadas por criminosos, e por fim, a incapacidade das autoridades em face de organizações de criminosos, cada vez mais presente nos Estados brasileiros.

Na cidade de Catanduvas, no Estado do Paraná, foi inaugurada em 23 de junho de 2006, a primeira Penitenciária Federal de Segurança Máxima do país. Foram investidos R $\$ 20$ milhões de reais no presídio que é extremamente seguro e que tem como finalidade resolver os problemas da carceragem tanto do estado do Paraná como de outros estados, já que a penitenciária recebe detentos de outras instituições. A penitenciária fica localizada a $470 \mathrm{~km}$ da capital paranaense e abriga bandidos que comprometem a segurança dos presídios, ou que estejam em Regime Disciplinar Diferenciado (RDD).

O RDD consiste em uma medida dura, que prevê o recolhimento do criminoso quanto às seguintes condenações: crime doloso a vida, conduta que ocasione subversão da ordem ou disciplina interna, quando o criminoso apresenta alto risco para a ordem pública e segurança do presídio ou da sociedade e quando recaia sobre o preso comprovado envolvimento ou participação em organizações criminais.

Além da Penitenciária Federal de Catanduvas o governo prevê a finalização e construção de outros presídios federais em outras regiões, como os de Campo Grande (MS), Mossoró (RN), Porto Velho (RO) e um no estado do Espírito Santo. A ideia é que cada região brasileira tenha a sua penitenciária federal, onde serão transferidos criminosos de alta periculosidade - condenados ou provisórios, a disposição da Justiça Estadual e Federal.

O Brasil tem vivido nos últimos anos uma realidade de um sistema penitenciário com crescentes e intensas crises decorrente dos mais diversos motivos possíveis, dentre as quais, já destacados em capítulos anteriores, mas principalmente o déficit de vagas prisionais.

De $10 \%$ a $20 \%$ dos presos brasileiros podem estar contaminados com o vírus da AIDS.

A maioria dos presos cumprem penas de quatro a oito anos de reclusão, por crimes como: roubos, furtos, tráfico de drogas etc.

Para solucionar o problema da superlotação nos presídios, seria necessário construir 145 novos estabelecimentos, a um custo de 1.7 bilhões de Reais. 
Os crimes mais comuns no Sul e Sudeste do Brasil são roubo e furto, enquanto que no Amazonas e no Acre o crime mais comum é o tráfico de drogas. Alagoas é o estado onde há mais presos por homicídio. Chegam ao número expressivo de $56,8 \%$ da massa carcerária.

Já no Nordeste e Centro-Oeste, a maioria das prisões ocorre por assassinato.

São Paulo é a cidade onde há maior número de presos por habitantes e também a pior situação carcerária: 174 presos para cada grupo de 100.000 habitantes.

Em Alagoas, por outro lado, há apenas 17 presos para cada 100.000 habitantes, os dados não são animadores, apenas refletem a impunidade que prevalece no estado. Mais da metade dos presos alagoanos são homicidas.

O Estado do Rio Grande do Sul é que reúne as melhores condições carcerárias. Não há preso em situação irregular.

Não se dispõe de dados precisos e sistemáticos sobre a demografia e as características das pessoas privadas de liberdade. Não obstante, os dados de que efetivamente se dispõe indicam que há mais de 9,25 milhões de pessoas presas no mundo, cumprindo prisão preventiva ou condenados, quase a metade se encontra nos Estados Unidos da América (2,19 milhões), China (1,55 milhões) e na Federação da Rússia (870.000), segundo dados do Relatório sobre o Direito à Educação apresentando junto ao Conselho de Direitos Humanos da ONU em Assembléia Geral no dia 02 de junho de 2009.

Os motivos do encarceramento são diversos e o perfil dos presos é complexo, isso refleti situações de desvantagem social e a freqüente vulnerabilidade resultante ou não de atos de violência individuais e aleatórios. $\mathrm{O}$ encarceramento por sua própria natureza aumenta a situação de desvantagem social e a vulnerabilidade às violações dos direitos, as medidas adotadas pelos Estados para respeitar e proteger os direitos das pessoas privadas de liberdade são de extrema importância.

Hoje o número de detentos na Prisão Federal dos EUA é de 628.000, sendo que $90 \%$ possuem pena de no mínimo 08 anos. A população carcerária aumentou 7\% desde 1988.

O governo da Suécia despende US\$ 61.000 dólares/ano por preso.

O governo dos EUA destina US\$ 25.000 a 30.000 dólares/ano para a manutenção da prisão e salário para o prisioneiro. Sendo que a prisão de Massachusetts, oeste da Virgínia, recebe algo próximo a US\$ 140.000 .

O governo do Brasil destina US\$ 4.300,00 dólares/ano a cada preso. Cerca de 06 vezes menos que o americano.

O presídio de Cascavel/PR recebe $\mathrm{R}$ \$ 0.14 mensais, para manutenção, alimentação, limpeza, e "salário" para o prisioneiro! Mesmo com este absurdo, os presos não se queixam da alimentação, e ainda ressaltam: "comemos melhor do que muita gente lá fora. Aqui tem carne todos os dias".

O referido presídio encontra-se em péssimas condições de administração, contando apenas com 01 
funcionário público, o carcereiro. O restante dos ajudantes no cárcere, num total de 08 são presos considerados de "confiança".

A maioria dos presidiários no Brasil tem uma cara: são homens de 18 a 24 anos, com baixa escolaridade e que não estão detidos pela primeira vez. Os dados são do Departamento Penitenciário Nacional (DEPEN), que indicam a existência de um déficit de 200 mil vagas nos presídios. Na Câmara, uma CPI se propõe a buscar soluções para o sistema carcerário brasileiro. Ela foi criada um dia antes do massacre da cadeia de Ponte Nova (MG), onde 25 presos morreram carbonizados numa briga entre gangues rivais.

No Brasil, existem cerca de 450 mil pessoas cumprindo pena - grande parte delas em recintos precários e provisórios, devido à superlotação dos presídios, causada pelo déficit de vagas. Um fator que aparece com muita freqüência nas estatísticas negativas, relacionadas com todo tipo de problemas sociais, é a baixa escolaridade.

Essa característica parece ter relação direta com o cometimento dos crimes. A maioria dos homens e mulheres que estão sob a punição máxima da lei brasileira não chegou a completar o ensino fundamental. São quase 150 mil pessoas, o que equivale a aproximadamente $35 \%$ do total de presos. Por outro lado, apenas 1.463 presidiários (menos de 1\% do total) têm curso superior e 58 fizeram pós-graduação.

Para o relator da CPI do Sistema Carcerário da Câmara, deputado Domingos Dutra (PT-MA), a superlotação dos presídios, cadeias e delegacias pode ser a origem real para todos os outros problemas que afetam o setor. "Isso avilta a situação dos presos, que se concentram num curto espaço físico. Além disso, desfigura a Lei de Execução Penal, que prevê a individualização da pena”, afirmou.

O professor Antônio Flávio Testa, cientista político e especialista em segurança pública, concorda que "o sistema é precário". "O Estado não tem condições de cumprir as suas próprias determinações."

Mesmo considerando-se o fato de muitas secretarias de Segurança Pública estaduais não enviarem informações ao DEPEN, constata-se que a maioria dos detentos não está presa pela primeira vez. Entre os homens, os reincidentes são mais de 90 mil. Isso reforça o argumento de parlamentares e especialistas que defendem a reintegração dos presos através dos programas de ressocialização.

O presidente da CPI do Sistema Carcerário, deputado Neucimar Fraga (PR-ES), lembra da existência da ideia de que investir em quantidade e qualidade de presídios é "regalia para presos". Ele defende que isso tem que ser modificado. Fraga acredita que, sem investimentos nos programas de ressocialização e, principalmente, na viabilização das penas alternativas, a crise não poderá ser superada.

A adoção de penas alternativas pode ajudar a acabar com a superlotação. Segundo especialistas, além de incentivarem a ressocialização, elas contribuem para os condenados não ficarem isolados e ociosos dentro de uma penitenciária. Um dos defensores da ideia é Jomar Alves Moreno, presidente da Comissão de Direitos Humanos da Ordem dos Advogados do Brasil no Distrito Federal.

Segundo ele, se fossem dadas condições aos juízes de expedirem penas alternativas à prisão, o número de internos cairia de $30 \%$ a $40 \%$. Hoje, alega-se que as medidas alternativas são pouco utilizadas por não haver estrutura para fiscalizar o cumprimento delas. 
Além de diminuir os gastos com os presos, essas punições teriam caráter educativo e não permitiriam que criminosos de vários tipos ficassem juntos. Atualmente, não há separação dos presos por tipo de crime.

Domingos Dutra acha importante isolar criminosos perigosos dos que cometeram delitos pequenos. Ele defende a criação, em cada presídio, de comissões de classificação para fazer essa triagem. "Há verdadeira salada de presos. Não se pode deixar um traficante de drogas na mesma cela em que está alguém preso por pequenos desentendimentos."

Flávio Testa não acredita que todos os presos possam ser recuperados. Problemas de ordem estrutural e cultural, originados pela desestruturação familiar e desamparo do Estado, fazem, segundo ele, com que muitos não consigam se ressocializar. Por isso, ele enfatiza que apenas as medidas punitivas não são suficientes.

O especialista cita outros fatores responsáveis pelo caráter crônico da crise do sistema carcerário. "A falta de investimento no planejamento familiar, na geração de emprego e renda e a construção de uma mentalidade que se guie pela formalidade e pela legalidade são fatores de fundamental importância para diminuir os altos índices de criminalidade", concluiu Testa.

O contingenciamento de verbas para a segurança pública é apontado pelo especialista como outro fator que incide na crise do sistema carcerário. Mas, segundo Fraga, desde o ano passado, esse problema não acontece e liberação de dinheiro para a área está normalizada.

Para o deputado, o fator tempo é dramático quando o setor de segurança se vê diante do contingenciamento. Na sua avaliação, o corte de verbas paralisa projetos em andamento e não basta a liberação de recursos de um momento para outro se não há tempo suficiente para que bons projetos sejam elaborados. Para esse problema, o deputado afirmou que a CPI buscará mecanismos para evitar o não repasse de recursos.

O presidente da CPI defende a terceirização das cadeias e penitenciárias. De acordo com Fraga, em gestões terceirizadas, o índice de mortes, fugas, rebeliões e tráfico de armas e drogas diminuiu drasticamente. Por meio de licitação, a administração do presídio passaria às mãos de uma empresa responsável por todos os serviços, desde a alimentação e limpeza até a segurança dos detentos.

Há quem discorde. O presidente da Federação Brasileira dos Servidores do Sistema Carcerário, Luiz Fernando Correia da Rocha, acredita que a segurança não pode ser feita por empresas. Para ele, esses funcionários não teriam o comprometimento que os agentes penitenciários têm com a instituição, o que aumentaria a corrupção nos presídios.

"O que acontece com um funcionário terceirizado se descumprir as normas? Apenas será demitido", afirmou o presidente. Ele defende que apenas serviços como alimentação sejam terceirizados. Contudo, Fraga já avisou que essa proposta será encaminhada no relatório final da CPI.

Os presídios brasileiros, habitados por 450000 sentenciados, têm cheiro de creolina. O produto químico é usado para disfarçar outro odor, o de esgoto, que sai das celas imundas e impregna corredores e pátios. $\mathrm{O}$ exemplo mais repugnante é o Presídio Central de Porto Alegre, considerado o pior do país. Num de seus pavilhões, as celas não têm sequer portas. No extremo oposto, figura a Penitenciária Industrial de 
Joinville, em Santa Catarina. Ela não cheira a prisão brasileira. Os pavilhões são limpos, não há superlotação e o ar é salubre, pois os presos são proibidos até de fumar. Muitos deles trabalham, e um quarto de seu salário é usado para melhorar as instalações do estabelecimento.

Nada que lembre o espetáculo de horrores que se vê nas outras carceragens, onde a maioria dos presos vive espremida em condições sub-humanas, boa parte faz o que quer e os chefões continuam a comandar o crime nas ruas a partir de seus celulares. A penitenciária catarinense é uma das onze unidades terceirizadas existentes no Brasil. Funciona assim: a empresa privada recebe do estado a tarefa de administrar o presídio, o que inclui fazer a segurança interna e prestar serviços básicos aos detentos, como alimentação, vestuário e atendimento médico.

Ao estado cabe fiscalizar o trabalho da empresa, fazer o policiamento nas muralhas e decidir sobre como lidar com a indisciplina dos detentos. O resultado tem sido tão positivo que os governos de Pernambuco e Minas Gerais resolveram dar um passo além e criar as primeiras Parcerias Público-Privadas do sistema prisional. Em Pernambuco, a construção do Centro Integrado de Ressocialização de Itaquitinga, um complexo penal com capacidade para 3.126 presos, está prevista para começar em abril de 2009 e custará 263 milhões de reais. O complexo penal em Ribeirão das Neves, em Minas Gerais, com três mil vagas, está na última fase de licitação.

Ao contrário da terceirização, em que a iniciativa privada recebe a prisão a ser administrada, na parceria público privada a empresa parceira tem de construir o presídio do zero com recursos próprios ou financiados. $\mathrm{O}$ custo da obra é ressarcido aos poucos à iniciativa privada, diluído nas mensalidades que o estado paga pelo serviço de gestão do presídio. "Uma das vantagens do modelo é que o poder público não precisa fazer um grande investimento inicial em infraestrutura", diz Ângelo Roncalli de Ramos Barros, secretário de Justiça do Espírito Santo. O desempenho dos dois presídios terceirizados do estado (um terceiro está em fase de licitação), que nunca tiveram superlotação nem rebeliões, levou o governo do Espírito Santo a estudar a possibilidade de também adotar parcerias público privadas em suas prisões.

Entre os fatores que explicam a eficiência da gestão privada, o principal é o fato de os empresários terem um motivo bastante objetivo para prestar um bom serviço aos presos e, ao mesmo tempo, manter a disciplina no presídio: proteger o próprio bolso. "Os prejuízos causados por uma rebelião, por exemplo, são pagos pela empresa - e comida boa e assistência jurídica eficiente são alguns dos elementos capazes de manter os condenados tranquilos", diz Sandro Cabral, professor de administração da Universidade Federal da Bahia e autor de uma tese de doutorado sobre os aspectos econômicos da terceirização prisional.

A empresa também pode perder a concessão do presídio caso não cumpra com alguns requisitos, como evitar fugas. Isso estimula os cuidados com a segurança e aumenta o esforço na revista dos visitantes, para coibir a entrada de celulares e armas. No Conjunto Penal de Lauro de Freitas, na região metropolitana de Salvador, por exemplo, os familiares e amigos não podem levar comida - o tradicional "jumbo" - aos presos. Em outras penitenciárias baianas, há casos de mães que chegam no dia da visita com um panelão de caruru, esconderijo perfeito para um revólver ou saquinhos com droga. Outra vantagem da terceirização é a agilidade com que os agentes penitenciários podem ser demitidos, caso sejam suspeitos de corrupção. Se fossem funcionários públicos, o processo demoraria mais de dois anos.

$\mathrm{O}$ argumento mais sério contra a terceirização e, por consequência, contra as parcerias público privadas 
em presídios é a aparente inconstitucionalidade de entregar à iniciativa privada o papel de aplicar a pena a um condenado. $\mathrm{O}$ argumento nesse sentido é que, como se trata de uma atribuição do estado, seria impróprio contratar agentes particulares para fazê-lo. "Funções como essas devem ser exercidas por funcionários públicos porque, por lei, exige-se deles um comprometimento maior com sua atividade", diz Sérgio Salomão Shecaira, presidente do Conselho Nacional de Política Criminal e Penitenciária, subordinado ao Ministério da Justiça.

Como a lei não proíbe textualmente a terceirização, no entanto, as interpretações variam. No entendimento de alguns juristas, a administração privada é constitucional, desde que os agentes penitenciários trabalhem sob as ordens de uma autoridade estatal. Assim, o estado não abdica de seu monopólio do uso da força. "O agente privado pode até ter a chave do cadeado, mas todas as decisões em relação ao preso são tomadas por um juiz ou, em menor escala, pelo diretor do presídio", diz a promotora de Justiça de São Paulo Deborah Kelly Affonso, autora de uma dissertação de mestrado sobre o assunto. Por essa razão, nas penitenciárias terceirizadas costumam trabalhar três ou mais funcionários públicos, em geral diretores e chefes de segurança, cuja obrigação é controlar e fiscalizar a atuação da empresa concessionária e de seus empregados.

"Quando um preso age com indisciplina, cabe a nós, representantes do estado, decidir se é o caso de mandá-lo para a solitária", exemplifica o policial militar Richard Harrison Chagas dos Santos, diretor da penitenciária de Joinville. Esse modelo, que será mantido nas PPPs de Pernambuco e Minas Gerais, é semelhante ao da França, onde quase $15 \%$ dos presídios são administrados em conjunto por estado e iniciativa privada. Nos Estados Unidos, o modelo é mais radical. Todos os funcionários são da concessionária, inclusive os diretores, e os prédios não pertencem ao governo, nem serão repassados à esfera pública no fim do contrato. Do total de presos americanos, $7 \%$ estão sob a guarda de empresas privadas. Parece pouco, mas equivale a uma população de mais de cem mil pessoas.

A tendência de terceirização foi revertida em dois estados brasileiros. No Ceará, a Justiça determinou o fim da gestão privada de três presídios, por causa de irregularidades nos contratos. No Paraná, seis prisões também foram retomadas pelo estado, em 2006, mas por uma idiossincrasia. "O governador resolveu, simplesmente, que o Paraná não deveria ter nada terceirizado", diz o secretário de Justiça, Jair Ramos Braga. Ele garante que as condições nos presídios até melhoraram depois que voltaram para a mão do estado - pioneiro, em 1999, na terceirização carcerária. A realidade, no entanto, mostra que dificilmente o sistema público consegue ser mais eficiente. As diferenças são superlativas. Vizinho à Penitenciária Industrial de Joinville há um presídio público.

Lá, as visitas íntimas acontecem dentro das celas superlotadas. A penitenciária ao lado, terceirizada, dispõe de dez quartos específicos para os presos receberem suas mulheres, com banheiro, chuveiro quente, ventilador, rádio e total privacidade. Costuma-se dizer que o sistema prisional brasileiro é uma faculdade do crime: os detentos saem de lá piores do que entram. Quando se consegue impor disciplina e dar condições básicas, como estudo e trabalho, os condenados têm ao menos uma chance de escolher seu rumo ao voltar à sociedade.

É bem verdade que não podemos atribuir como causa da reincidência, somente o fracasso da prisão. Temos que levar em consideração a contribuição de outros fatores pessoais, políticos e sociais.

O direito à salvaguarda da dignidade, o direito ao respeito da pessoa humana, o direito à intimidade são os 
direitos mais agredidos na maior parte das prisões do mundo. Desde a admissão, começa o despojamento da personalidade do preso, algemas nos pulsos, revista no corpo nu, à vista de todos, a troca de traje pessoal e uso de chuveiros na presença de guardas, etc.

O direito à informação, já enunciado no art. 26 da Declaração Universal dos Direitos do Homem e do Cidadão, é de vital importância para a ressocialização do detento, pois tanto humaniza o regime penitenciário, como concorre para o aprimoramento cultural do recluso. O direito à comunicação com o mundo exterior abre a prisão ao mundo livre e visa à desinstitucionalização da prisão. $\mathrm{O}$ condenado não pode perder o contato com a sociedade, para qual se prepara gradativamente.

A liberação sem o prévio preparo, como o tratamento reeducativo, e sem colaboração da sociedade na reinserção social do preso, é traumatizante e fator de delinquência.

A importância do papel do advogado é bastante percebida pelos entrevistados, presos ou não-presos. Reconhecem que a sorte do processo depende, em grande parte, da atuação dos causídicos. Depositam grande esperança nas mãos do advogado e do juiz.

O Departamento Penitenciário Brasileiro vem realizando um programa nacional de formação e aperfeiçoamento do servidor, mediante convênios com os Estados, cursos de formação do pessoal penitenciário e de extensão universitária para diretores e pessoal de nível superior, juntamente com cursos de especialização e pós-graduação do pessoal do sistema penal em todo o território nacional.

O Ministério da Justiça, desde a sua primeira programação penitenciária, vem construindo estabelecimentos penitenciários em todas as unidades da Federação, de acordo com o Programa de Reformulação e Sistematização Penitenciária, que determina perspectivas inéditas à arquitetura carcerária nacional. O moderno estabelecimento deve permanecer ao nível da dimensão humana.

O homem, como forma de sobreviver em sociedade, sempre procurou agrupar-se ao fito de resistir às forças da natureza, e, desse modo, estabelecer ações de maneira cooperativa. Ao passo que desenvolveu a linguagem, dando-lhe a consciência reflexiva, propiciou a conjugação das atividades no esforço de transformar o mundo. Nesse contexto diversas culturas se originaram em cada comunidade de acordo com o modo de interpretar a realidade e transformá-la segundo suas necessidades. Cada cultura tem, portanto, suas construções próprias: alimentação, costumes, religião, arquitetura, política, valores, etc.

Na realidade, a "postura humana" é aprendida em comunidade. Tal assertiva implica reconhecer que não há seres humanos fora de um contexto social. Em decorrência de um processo educativo primário, cujo principal veículo é a linguagem, surge, no contexto sociocultural, o homem.

Segundo alguns autores, esse processo de educação primária (leia-se, aprender a ser humano) é chamado de socialização. Tomando-se por base o contexto sociocultural em que está inserida, a criança é socializada: "adquire uma linguagem e, com ela, uma determinada forma de falar, pensar e agir, segundo a cultura onde está (...). Pode-se então falar no 'estilo de vida do chinês', no 'modo britânico de ser', no 'american way of life' e no 'jeitinho que o brasileiro sempre dá."

Esse processo de "socialização" - quando se aprende a ser humano - também define o estilo de vida de uma comunidade; adquire-se, com ele, a personalidade cultural. 
Esse mecanismo, pelo qual o indivíduo é iniciado no estilo de vida de uma cultura, é chamado de endoculturação. Pode-se afirmar, então, que endoculturação é o processo pelo qual todos os indivíduos passam "interiorizando" um estilo cultural de viver. É, o que, aliás, se constata na cultura do cárcere: o preso é submetido a um processo constante de interiorização de um estilo de vida muito peculiar e institucionalizado em face da nova realidade presente.

Nesse estágio de endoculturação o papel da educação e dos educadores (leia-se, também, os profissionais que atuam no Sistema penitenciário) constitui a viga mestra, o sustentáculo, para iniciar o preso no processo de ressocialização. Torna-se necessário desenvolver uma comunicação intensa ao fito de resgatar e elevar sua auto-estima.

Os autores das análises antropológicas modernas convergem para um sentimento de reconhecimento dessa necessidade, de uma "comunicação mais intensa com a existência (...) de volta às origens, às raízes, à matriz, quer sob a forma simbólica e social de reencontro com a natureza, quer sob a forma históricoantropológica. Assim poderá ser reencontrada a linguagem de grupos humanos reduzidos ao silêncio e resgatando tudo que a Cultura dominante absorve 'tranquilamente' (...)".

A educação, no contexto sociocultural, que deveria significar o auxílio aos indivíduos para que pensem sobre a vida que levam; que deveria permitir uma visão do todo cultural onde estão, desvirtua-se na escola. Nesta, as pessoas são preparadas para executar trabalhos parcializados e mecânicos no contexto social. A escola mantém e estimulam a separação da razão e do pensamento, dês que sua finalidade é preparar mão-de-obra à sociedade industrial; transmitir conceitos desvinculados da vida concreta dos educandos, impondo desconsiderar o risco da visão de mundo das classes dominantes.

Com efeito, a educação precisa transmitir significados presentes na vida concreta de quem se pretendem educar ou reeducar; de modo diverso, não produz resultado, aprendizagem.

Mediante a consciência reflexiva, simbólica, o homem desenvolve a linguagem, utilizando-se da palavra; dá sentido à vida, segundo os significados que advêm fundamentalmente dos símbolos, das palavras, dos nomes. Assim, os conceitos (símbolos) são necessários às experiências dos indivíduos em conexão à realidade. Logo, o processo da aprendizagem precisa mobilizar tanto os significados, os símbolos, quanto os sentimentos, as experiências a que eles se referem.

O Brasil ainda não tem uma cultura de respeito aos direitos humanos dos presos. A afirmação é do secretário de Educação Continuada, Alfabetização e Diversidade do Ministério da Educação (Secad), André Lázaro, que defende a necessidade de implementação do Plano Nacional de Educação no Sistema Prisional.

Segundo o secretário, ainda é necessário discutir uma série de melhorias para contribuir com a ressocialização dos detentos. "Se a sociedade não os civilizar, quem o fará? Os presos nos civilizarão com a violência? Temos que assumir nosso papel, dando educação", disse Lázaro, ao participar do seminário. Ele aponta muitas dificuldades no processo, como a falta de espaço físico nas unidades prisionais e a desarticulação entre as secretarias responsáveis pela administração de educação e penitenciárias, além da formação de professores dispostos a atuar nesses locais.

De acordo com Lázaro, a educação é uma condição mínima de reintegração. Ele citou dados da Fundação de Amparo ao Trabalhador Preso (Funap) do Distrito Federal, segundo a qual o índice de reincidência de crimes dos egressos caiu de $70 \%$ para $30 \%$ este ano, com o trabalho de ressocialização por meio do 
ensino.

"A realidade hoje no Brasil é que, de aproximadamente 460 mil presos, 22 mil são analfabetos, 56 mil, apenas alfabetizados, e 145 mil têm somente o ensino fundamental completo", ressaltou o secretário.

O diretor do Departamento de Avaliação da Secad, Jorge Telles, por sua vez, enfatizou que o ensino não é um privilégio para os detentos, mas um direito: "Não estamos simplesmente dando uma tarefa, ou 'amansando' os presos. O acesso à educação é um direito de todos."

\subsection{REINTEGRAÇÃO SOCIAL}

As ações de reintegração social podem ser definidas como um conjunto de intervenções técnicas, políticas e gerenciais levadas a efeito durante e após o cumprimento de penas ou medidas de segurança, no intuito de criar interfaces de aproximação entre Estado, Comunidade e as Pessoas Beneficiárias, como forma de lhes ampliar a resiliência e reduzir a vulnerabilidade frente ao sistema penal.

Partindo-se desse entendimento, vê-se que um bom "tratamento penal" não pode residir apenas na abstenção da violência física ou na garantia de boas condições para a custódia do indivíduo, em se tratando de pena privativa de liberdade: deve, antes disso, consistir em um processo de superação de uma história de conflitos, por meio da promoção dos seus direitos e da recomposição dos seus vínculos com a sociedade, visando criar condições para a sua autodeterminação responsável.

$\mathrm{Na}$ conformação atual das práticas gerenciais do DEPEN, considera-se que os projetos na área de Reintegração Social devem estar posicionados entre alguns eixos básicos: Formação Educacional e Profissional dos Apenados, Internados e Egressos do Sistema Penitenciário Nacional diz respeito ao processo pelo qual se procura associar a elevação da escolaridade e a educação profissional, com o acesso ao trabalho e à geração de renda, de maneira a preparar o beneficiário para ingresso no mundo do trabalho após o cumprimento da pena privativa de liberdade, principalmente no que concerne à capacitação das mulheres em privação de liberdade.

Assistência ao Preso, ao Internado, ao Egresso e aos seus Dependentes faz referência a um movimento de promoção dos direitos dos apenados, internados, egressos, dependentes e familiares, criando condições para que estes possam exercer a sua autonomia. Esse processo deve ser mediado pela inclusão dos beneficiários na agenda das políticas públicas de governo e pelo apoio a ações de instituições públicas e privadas, de caráter permanente, que tenham como objetivo prestar atendimento aos beneficiários, na forma e nos limites da lei: material, jurídica, educacional, social, religiosa e principalmente à saúde ao egresso, após a edição do Plano Nacional de Saúde no Sistema Penitenciário.

O homem quanto ser social, entrega ao Estado à responsabilidade de prevenir a prática de delitos e promover a reinserção social do condenado; acreditando-se que somente a força da lei será suficiente para que a marginalidade diminua.

As teorias voltadas para a finalidade da pena mostraram ao longo dos anos, que somente o Estado não é capaz de resolver o problema da marginalidade. É necessária uma consciência de que se há aumento de violência, também deve estar ocorrendo aumento da exclusão social. Cabe a toda sociedade identificar as causas e atacá-las devidamente.

O que não se pode deixar é os "oportunistas", que vêem no pânico social em relação ao aumento da violência, um motivo para defender idéias desumanizadoras como: pena de morte. Precisamos avançar em 
nossos direitos e permitir que todos sejam cidadãos plenos e isso só ocorre quando a pena for vista em toda a sua extensão social, quando for permitido ao homem entender os seus atos, diante do coletivo e corrigi-los; permitindo que seja novamente inserido na sociedade.

O que irá diminuir a violência e os conflitos sociais não é a intensidade ou o agravo da pena, e sim a certeza que não passará impune; penas alternativas, menores e com uma certeza que será aplicada inibirá com maior eficácia a prática delituosa; evitando que um criminoso com um grau de periculosidade, relativamente pequena, se torne um elemento de alta periculosidade, perdendo assim a oportunidade de ressocializá-lo de uma forma humana e eficiente.

Falar em ressocializar, nos passa a ideia que reintegraremos na sociedade um individuo que era sociabilizado e foi retirado do convívio social como forma punitiva por alguma atitude anti-social (crime), o mesmo após sofrer a sanção prevista, deverá retornar ao convívio social de uma forma reeducada para não voltar na prática do delito; isto é o conceito ideal, mas a prática não confirma que funciona desta forma, até mesmo por querer ressocializar e reeducar quem nunca foi socializado nem educado.

Ressocializar ou punir? Continua sendo o maior enigma para uma sociedade que vive do medo. É preciso romper o medo, estabelecer a segurança social e ai sim discutir formas que permitam a sociedade, entender a necessidade de recuperar os nossos semelhantes de uma forma humanizadora.

\subsection{EDUCAÇÃO DE DETENTOS}

Em anos recentes tem se registrado um aumento considerável de forma geral em certos Estados das investigações relativas aos sistemas penitenciários, não obstante segue havendo uma escassez de investigações e debates sobre a educação nas prisões e particularmente sobre a forma em que os programas educativos se concebem, financiam e são acessíveis as populações penitenciárias. Dado o caráter das normas de direitos humanos, as investigações de caráter internacional e comparativo sobre os regimes carcerários são cada vez mais urgentes e os sistemas penitenciários devem cooperar e aprender uns com os outros.

A comunidade internacional se preocupa desde há muito tempo pela humanização da justiça penal, a proteção dos direitos humanos e a importância da educação no desenvolvimento da pessoa e da comunidade.

A Assembléia Geral da ONU em 1990 em sua resolução 45/111, aprovou os princípios básicos para o tratamento dos reclusos, dentre eles:

a) Todos os reclusos serão tratados com respeito que merece sua dignidade e valor inerentes de seres humanos (art. 1);

b) Com exceção das limitações que são evidentes e necessárias pelo fato do aprisionamento, todos os reclusos seguirão gozando dos direitos humanos e das liberdades fundamentais consagradas na declaração universal das direitas humanos e, quando o Estado de que se trate seja parte no Pacto Internacional de Direitos Econômicos, Sociais e Culturais e o Pacto Internacional de Direitos Civis e Políticos e seu Protocolo Facultativo, assim como todos os demais direitos estipulados em outros instrumentos das Nações Unidas (art. 5);

c) Todos os reclusos terão direito a participar das atividades culturais e educativas direcionadas a desenvolver plenamente a personalidade humana (art. 6). 
As normas jurídicas e políticas internacionais seguiram tendo um efeito limitado enquanto a comunidade internacional, cuja atuação tenta regular, não apoie plenamente os princípios em que se fundam. No que se atenham as pessoas privadas de liberdade, esse apoio esta tardando a chegar. A elaboração de normas internacionais juridicamente vinculantes e de orientações conexas sobre a educação nos estabelecimentos penitenciários e por certa bem vida e contribui a documentar o debate internacional sobre o tratamento dos reclusos, especialmente no que se respeita o seu acesso a educação. Pese a que os Estados têm desempenhado um papel fundamental na elaboração dessas normas, seu pleno cumprimento segue sendo uma exceção.

$\mathrm{Na}$ atualidade o direito a educação incluiu a disponibilidade, acessibilidade, adaptabilidade e aceitabilidade, nenhum texto jurídico prevê a perda desse direito, o que é mais importante, esta perda não é uma exigência da privação da liberdade.

Profundas mudanças globais, sociais, políticas e econômicas tiveram um impacto forte em todos os sistemas penitenciários. Embora estes sistemas variem, posto que reflitam características, línguas, culturas políticas, populações, filosofias e instituições particulares a cada Estado. Apesar das diferenças entre os sistemas penitenciários é evidente que para todos eles a participação dos reclusos em atividades educativas é um problema essencialmente complexo e que, quando existe, se dá em um meio inerente e hostil frente a suas possibilidades libertadoras.

Presente desde os primórdios da prisão, a educação é arrolada como atividade que visa a proporcionar a reabilitação dos indivíduos punidos. Contudo, considerando que os programas da operação penitenciária apresentam-se de forma premente a fim de adaptar os indivíduos às normas, procedimentos e valores do cárcere - afiançando, portanto, aquilo que se tornou o fim precípuo da organização penitenciária: a manutenção da ordem interna e o controle da massa carcerária - quais são as possibilidades para uma "educação autêntica, que não descuide da vocação ontológica do homem, a de ser sujeito" (Freire, 1979, p. 66).

No interior das prisões, as contradições do processo de ajustamento materializam-se nas possibilidades concretas dos indivíduos punidos preservarem-se como sujeitos; na resistência a subjugarem-se plenamente aos valores da instituição e do sistema social que lhe é inerente.

A resistência prisioneira ao controle carcerário (...) é muito mais forte e presente que seu raro registro na literatura faz supor (...). As pessoas presas conseguem manter a identidade, os valores de origem e grupais, a perspectiva de vida e de liberdade, a despeito das longas condenações e de todos os fortes e rigorosos meios de controle e sujeição utilizados pela instituição penitenciária. (Rocha, 1994, p. 3).

A educação formal não permanece, em absoluto, neutra nesse processo pleno de contradições de subjugação e resistência. "A característica fundamental da pedagogia do educador em presídios é a contradição, é saber lidar com conflitos, saber trabalhar as contradições à exaustão" (Gadotti, 1993, p. 143).

Por um lado, as rígidas normas e procedimentos oriundos da necessidade de segurança, ordem interna e disciplina das unidades que prescrevem as atividades escolares, a vigilância constante ou até mesmo a ingenuidade dos educadores, podem contribuir para que a escola seja mais um dos instrumentos de dominação, subjugando os indivíduos punidos ao "sistema social da prisão" (Sykes, 1999, p. 9) e ao 
"mundo do crime" (Ramalho, 1979, p. 163). Por outro lado, a escola pode apresentar-se como um espaço que se paute por desenvolver uma série de potencialidades humanas, tais como: a autonomia, a crítica, a criatividade, a reflexão, a sensibilidade, a participação, o diálogo, o estabelecimento de vínculos afetivos, a troca de experiências, a pesquisa, o respeito e a tolerância, absolutamente compatíveis com a educação escolar, especificamente a destinada aos jovens e adultos.

Nos estabelecimentos penais, a educação compõe a área de reabilitação, sendo a ela subordinada hierarquicamente. A manutenção de suas atividades, contudo, em todo o tempo, observou a participação de outras instituições não pertencentes propriamente à unidade prisional. Sua organização e funcionamento são decorrentes, dessa forma, das normas e diretrizes das instituições que as coordenaram, ao longo dos anos.

Até o final da década de 1970, as escolas no interior das unidades prisionais regulavam-se observando a organização da rede regular de ensino estadual. O calendário escolar, o material didático, os processos de avaliação e promoção de séries eram análogos aos do ensino destinado às crianças.

A inadequação dessa proposta é patente. O primeiro aspecto reside na renúncia em inserir os encarcerados na educação destinada aos adultos, corporificada no cenário educacional brasileiro desde a década de 1930. Um segundo aspecto a acometer a qualidade desse ensino relaciona-se à extrema rotatividade da população carcerária entre as unidades do sistema penal. Um ensino de oito séries anuais, afora a possibilidade de repetência dos alunos, praticamente inviabiliza a conclusão dessa fase escolar pelos encarcerados.

Proeminente, nesse sentido, foi à iniciativa da Funap que é uma fundação de interesse e direito públicos, que tem como missão "contribuir para a inclusão social de presos e egressos do Estado de São Paulo, estimulando seu potencial como indivíduos, cidadãos e profissionais". Dentre as ações desenvolvidas pela Funap, destacam-se os programas de educação, cultura, alocação de mão-de-obra e qualificação profissional e assistência judiciária. A Funap é órgão da própria Administração Penitenciária, em firmar convênio com duas instituições responsáveis pela educação de jovens e adultos: a Fundação Mobral Movimento Brasileiro de Alfabetização - e a Fundação Roberto Marinho. Além de passar a desempenhar um papel importante na organização das atividades escolares, a Funap possibilitou que o ensino nas prisões ocupasse um lugar próprio no cenário educacional brasileiro de jovens e adultos.

Sua organização efetivou-se observando as diretrizes programáticas da Fundação Mobral, posteriormente Fundação Educar, no que respeita ao ensino de $1^{\mathrm{a}}$ à $4^{\mathrm{a}}$ série. Denominado Programa de Educação Básica (PEB), foi subdividido em três etapas, PEB I, PEB II e PEB III, caracterizando, no sistema penal, o Nível I. Para o ensino de $5^{\mathrm{a}}$ à $8^{\mathrm{a}}$ série - o Nível II - conforme diretrizes da Fundação Roberto Marinho, que pressupõem a organização de grupo de alunos por disciplinas: Língua Portuguesa, Matemática, História, Geografia e Ciências, e o exercício da pluridocência.

O calendário letivo em todas as escolas do sistema penal paulista é organizado de fevereiro a julho. Após um recesso de quinze dias, o reinicio ocorre em agosto, estendendo-se até meados de dezembro. Entretanto, os motivos para o cancelamento das aulas não são poucos, mormente por questões relativas à segurança e disciplina.

Rotina da segurança em todas as unidades do sistema são as blitz. Caracterizam-se por revistas em todas 
as celas, normalmente planejadas em sigilo pela área de segurança, possuindo a prerrogativa de ser inesperada. Não existem períodos sistemáticos para sua realização, que varia segundo ocorrências no estabelecimento. Esse desígnio paralisa todas as atividades da unidade, pois os presos devem permanecer trancados nas celas para que se cumpra a revista.

Por vezes, a falta de agentes penitenciários também impede o funcionamento da escola. Os alunos presos são revistados quando saem do pátio para a escola e quando retornam. A falta de funcionários em determinados dias e horários impede a realização desse procedimento, impedindo a locomoção dos presos na unidade.

Na grande maioria dos estabelecimentos penais, a escola é o único local onde toda a população carcerária se encontra. No cotidiano permanecem separados nos raios onde estão dispostas suas celas. São comuns boatos de que algum "acerto de contas" (o termo enseja o uso da violência) entre os presos será efetuado na escola, oportunidade única para encontrar pessoas que estão em outros raios. Esse fato igualmente acarreta a interrupção das atividades.

Quando surgem ocorrências concretas na escola, tais como a descoberta de um túnel para fuga ou esconderijo de armas, as atividades escolares são suspensas por um período muito maior se comparado ao mesmo acontecimento em outro local da prisão $\mathrm{O}$ motivo alegado pelo corpo dirigente é o de que não se pode proibir o uso do pátio ou da cozinha, por exemplo, sem o risco de movimentos de motins ou rebeliões. No caso da escola, seu fechamento não traz conseqüências mais graves à ordem interna das prisões - prioridade da organização.

Afora os motivos de segurança, as aulas são paralisadas, inexoravelmente, uma vez por mês, no dia denominado como pecúlio. À população carcerária não é permitido manuseio de dinheiro. Aqueles que exercem alguma atividade remunerada apresentam uma lista de compras a ser efetuada pela penitenciária (Setor de Pecúlio), que repassa aos presos os produtos. Nesse dia, a escola permanece sem atividades.

A carga horária diária das aulas é de duas horas para cada turma, de segunda a sexta-feira. A diretriz, no que respeita ao número de alunos, preconiza que sejam matriculados vinte para cada classe de PEB I e vinte e cinco para cada um das demais fases do ensino fundamental.

É bastante comum, contudo, os diretores de educação das unidades excederem esse número. Ocorre uma quantidade razoável de faltas, principalmente nos locais em que a frequiência não é obrigatória. As justificativas para as ausências incidem: a) nos atendimentos de ordem jurídica, médica ou social; b) no trabalho, pois apesar de os alunos serem dispensados para as aulas, em momentos de picos de produção não há essa concessão, ocorrendo então a opção pelas oficinas que, além da remuneração, possibilita a remição de pena, na proporção de três dias trabalhados, um a menos na sentença; c) na opção do aluno em não ir à aula em determinado dia; d) na concorrência da escola com outras atividades da unidade, principalmente as esportivas. O registro de ausências é maior quando são realizados campeonatos. Normalmente, sobre esses campeonatos, incide uma rede de apostas dos encarcerados, daí então o grande interesse em acompanhá-lo.

Em determinados estabelecimentos penais existe a obrigatoriedade da freqüência à escola. Tal fato configura-se contrário à proposta de reabilitação penitenciária visto que o êxito dessa terapêutica penal funda-se na participação voluntária do apenado nos programas (Rodrigues, 1999). Ao pessoal 
penitenciário incumbe-se a motivação para tanto.

Concernente á obrigatoriedade da educação, contudo, a grande maioria das unidades prisionais adota um procedimento que consiste em não impor tal condição num primeiro momento. Porém, uma vez matriculado, o aluno não pode ausentar-se sem justificativa. Caso não possua o ensino fundamental completo e, mesmo assim não queira estudar, deve assinar um "termo de responsabilidade" que será anexado ao seu prontuário, o qual, concretamente, transfigura-se na imposição, observando-se o receio dos encarcerados em assumir formalmente não tencionar matricular-se na escola, pois que há um temor que a Comissão Técnica de Classificação, conforme veremos adiante, ao avaliar sua solicitação de benefício, leve em conta esse fato, negando-lhe a concessão.

Não obstante as dificuldades para o funcionamento regular da escola, observando-se os procedimentos da gestão penitenciária, um aspecto relativo à qualidade do ensino destinado aos homens e mulheres presos se sobressai. Trata-se da constituição da proposta de ensino supletivo no sistema penal paulista, a qual ensejou a possibilidade de ingresso do aluno encarcerado na escola a qualquer tempo, sem observar nenhum período preestabelecido, atentando-se para a especificidade da organização penal.

Sua inclusão efetiva-se após diagnóstico do seu desenvolvimento e aprendizagem escolares, realizados pelos próprios educadores. Denominado Processo de Triagem, constitui-se de três etapas, a saber: prova escrita de Língua Portuguesa e Matemática, entrevista e adaptação em sala de aula.

Esse processo de triagem deve ser realizado apenas na primeira vez em que o aluno se matricula no programa de educação da Funap. A partir de então, os dados relativos ao seu grau de aprendizado e respectiva etapa que está cursando, seriam registrados no documento individual do aluno, denominado Histórico Escolar, o qual é atualizado com as informações pertinentes ao seu desenvolvimento escolar. Esse documento acompanha o aluno na movimentação pelas unidades do sistema penitenciário, de forma a permitir sua reinserção na escola.

A estrutura do programa de educação: Nível I - PEB I, II e III - correspondente ao ensino de $1^{\mathrm{a}}$ à $4^{\mathrm{a}}$ série; e Nível II, de $5^{\mathrm{a}}$ à $8^{\mathrm{a}}$ série, conforme já citado, permaneceu no sistema penal do estado de São Paulo, mesmo após a extinção da Fundação Educar, em 1990. A certificação, até então realizada por aquela Fundação, passou a ser constituída como uma "Declaração de Conclusão" fornecida pela Funap, sem o reconhecimento do Ministério da Educação ou do Conselho Estadual de Educação. Essa Declaração possui um valor maior no interior das unidades prisionais. Anexada ao prontuário dos alunos, tem a finalidade de atribuir boa conduta carcerária ao seu portador, quando for organizar a solicitação dos benefícios previstos em lei, principalmente a progressão de regime, cujo parecer final cabe à Comissão Técnica de Classificação.

Tal modalidade de ensino, caracterizada como de suplência, não prevê a retenção do aluno em qualquer de suas etapas. A avaliação é realizada de forma contínua e, ao atingir os objetivos mínimos previstos para cada uma das fases, o aluno é promovido à fase seguinte. Esse critério encerra, ainda, a promoção do Nível I para o Nível II.

No que tange à conclusão do Nível II, o ensino fundamental, a avaliação é realizada por professores e instituições alheios ao processo de ensino e aprendizagem propriamente. Trata-se do Centro de Exames Supletivos (Cesu), órgão da Secretaria de Estado da Educação, responsável pela realização dos Exames 
Oficiais de Suplência em todo o estado de São Paulo.

As provas do Cesu, como são conhecidas nas escolas das prisões, são realizadas uma ou duas vezes por ano, sendo estendida aos alunos encarcerados. São organizadas por disciplina e um conceito igual ou superior a cinco, habilita o aluno-candidato a receber um atestado de aprovação naquela disciplina. $\mathrm{O}$ certificado de conclusão do ensino fundamental é obtido após a aprovação nas cinco disciplinas que compõem o currículo, atualmente: Língua Portuguesa, História, Geografia, Ciências e Matemática. Essa forma de avaliação dos alunos para certificação na educação fundamental encerra um paradoxo. Durante o percurso de ensino e aprendizagem, os processos de avaliação são contínuos, participativos e qualitativos. Ao final do percurso, para obter a certificação, o aluno é submetido a uma série de testes objetivos, identificados com conteúdos programáticos (Secretaria de Educação - Centro de Exames Supletivos, 1989) diversos daqueles constituintes dos materiais didáticos dos alunos.

A estrutura e o funcionamento do programa de educação de adultos presos sofreram alterações, a partir de 1997, decorrentes da implementação do Telecurso 2000.

O Programa de Educação Básica - PEB, com três etapas, passou a ser denominado Programa de Alfabetização, subdividido em apenas duas: Alfabetização I e Alfabetização II (ALFA I e II). A fase subseqüente da educação fundamental constituiu o Telecurso 2000, correspondente ao programa de ensino de $3^{\text {a à }} 8^{\text {a }}$ série, e organizada segundo a divisão das disciplinas que compõem o currículo: Língua Portuguesa, Matemática, História, Geografia e Ciências.

A proposta curricular para alfabetização foi igualmente alterada. Os objetivos e conteúdos pertinentes a essa fase escolar foram extraídos e readequados da Proposta Curricular para o $1^{\circ}$ Segmento do Ensino Fundamental de Jovens e Adultos (São Paulo: Ação Educativa; Brasília: MEC, 1997), elaborada pela organização não-governamental Ação Educativa, a partir de um amplo e democrático processo, que contou com a participação de organizações educacionais públicas e da sociedade civil, vinculadas à Educação de Jovens e Adultos, com o apoio da Secretaria de Educação Fundamental do MEC. A Funap esteve presente nesse percurso. Ao final do processo, o MEC manifestou interesse em co-editar e distribuir os resultados dos trabalhos, constituindo uma proposta curricular basilar à elaboração de projetos voltados para educação de jovens e adultos no âmbito nacional. (São Paulo: Ação Educativa; Brasília: MEC, 1997, p. 5).

Fundamenta essa proposta curricular a intenção de concorrer para a estruturação e organização de programas de educação destinados aos jovens e adultos "O objetivo deste trabalho é oferecer um subsídio que oriente a elaboração de programas de educação de jovens e adultos e, conseqüentemente, também o provimento de materiais didáticos e a formação de educadores a ela dedicados" (São Paulo: Ação Educativa; Brasília: MEC, 1997, p. 13).

A partir dessa orientação e com o propósito de manter a educação dos encarcerados inserida no cenário educacional brasileiro de jovens e adultos, a Funap desencadeou um processo, envolvendo coordenação e educadores, para a reorganização curricular destinada ao primeiro segmento do ensino fundamental (Funap, 1997). Foram seis meses para construção e implementação do projeto, caracterizado como piloto, a partir do qual foram constituídas as bases para sua difusão às demais unidades do sistema penal paulista, o que veio a ocorrer somente em 2001, devido à falta de recursos financeiros. 
Um aspecto não propriamente didático-pedagógico, relacionado à organização e ao funcionamento das escolas, requer relevância, pois sua interferência é decisiva qualitativamente para o programa de educação de adultos presos.

No interior das unidades prisionais, a educação é subordinada à área de reabilitação. Seu corpo técnico é o responsável pela realização dos exames criminológicos e emissão do parecer acerca da concessão dos benefícios solicitados pelos indivíduos presos.

Para essa concessão, conforme já mencionado, incide uma primazia em avaliar a adaptação do indivíduo punido ao sistema social da prisão, a partir da qual infere-se sobre sua reabilitação. Dessa forma, decorre que os encarcerados passam a organizar sua vida prisional e pautar sua conduta de forma a apresentar-se com um "bom preso", pois, do contrário, os benefícios lhes serão negados.

Esse proceder, invariavelmente, prejudica as atividades educativas, principalmente devido ao fato de que o setor de educação deve enviar à Comissão Técnica de Classificação um relatório sobre a conduta do aluno.

O processo educativo requer a participação ativa dos educandos nas aulas, numa série de "erros" e "acertos" que se constituem como parte do processo de aprendizagem. A necessidade de mostrar-se como um "bom preso" ao professor, com a intenção sub-reptícia de obter uma concessão, pode inviabilizar o processo educativo, mormente organizado tendo em vista o desenvolvimento de uma série de potencialidades dos alunos.

Observando-se que "fica difícil desenvolver efetivamente o programa de educação ou de trabalho, se eles estiverem ligados ao esquema de funcionamento da prisão" (Salla, 1993, p. 95), a participação do corpo docente nos exames e na elaboração dos pareceres percorre uma direção contrária: transportar para o espaço da sala de aula os procedimentos pertinentes à gestão penitenciária, suas normas, procedimentos e valores. Não obstante, o programa de educação de adultos presos apresenta-se com os objetivos de: a) "criar condições para o desenvolvimento e aprendizagem dos alunos de forma participativa e crítica"; b) "desenvolver as potencialidades dos alunos, preparando-os para o exercício pleno da cidadania"; c) "estimular e conscientizar os alunos para a importância dos estudos, buscando alternativas atrativas para a participação" (Rusche, 1995, p. 28), dos alunos em sala de aula na avaliação de sua conduta carcerária, torna-se aspecto acometedor para a consecução destas finalidades educativas.

O percurso que consolidou a organização e funcionamento das escolas no interior dos estabelecimentos penais evidencia, portanto, uma condensação de variados procedimentos pertinentes, de um lado, à gestão penitenciária e, de outro, ao fazer pedagógico propriamente.

O primeiro fato que poderíamos citar acerca da especificidade da Educação de Adultos Presos é o de que ela faz parte, enquanto processo metodológico, da História da Educação de Adultos e tem, portanto, seu desenvolvimento pedagógico inserido nessa história. O segundo fato é o de ser um projeto de educação que se desenvolve no interior das prisões e que, dessa forma, está inserido também na história das prisões e das formas de punição. (Rusche, 1997, p. 13)

Normas, valores e padrões identificados com estes dois aspectos, que perpassam a organização das atividades escolares destinadas aos encarcerados, raramente são passíveis de coadjuvarem-se. É no 
embate diuturno entre pressupostos e finalidades diferentes, até opostas, que emergem a organização e o funcionamento das escolas no sistema penal paulista.

As possibilidades e as contradições de uma "educação autêntica, que não descuide da vocação ontológica do homem, a de ser sujeito" (Freire, 1979, p. 66) configuram-se de forma preponderante nos aspectos metodológicos.

No interior das prisões, a metodologia é o fator diferencial do trabalho educativo, na medida em que possibilita, por um lado, o engajamento da educação aos procedimentos da gestão carcerária, pautados pelo princípio da punição e de manutenção da ordem interna das prisões. Por outro, permite a constituição desse trabalho, enquanto uma das possibilidades concretas para a preservação dos indivíduos punidos à subjugação carcerária.

As possibilidades da metodologia em desvincular as atividades educativas do esquema disciplinar das prisões materializam-se na prática de sala de aula: nas relações estabelecidas entre os alunos e destes com os educadores, na participação individual e em grupo nos trabalhos, no debate, nos questionamentos, na reflexão, no respeito, na tolerância, no diálogo e nos conteúdos. A observação desses aspectos pode contribuir para a constituição do espaço escolar, diferenciando-o da técnica penitenciária.

Nos interstícios das contradições, presentes e inerentes a todos os processos de dominação e subjugação, arrogam-se as possibilidades concretas para a constituição da escola, como espaço diferenciado da técnica penitenciária. O confronto direto ou a mera sublevação ante os procedimentos da gestão carcerária fatalmente acarretam a própria afirmação destes. Observando-se a nítida prioridade de manutenção da ordem interna das prisões, no cotejo avultam-se os preceitos relativos aos esquemas disciplinares e punitivos, solidificando-os na organização.

A década de 90 foi marcada pela extinção da Fundação Educar, pois, o atual Ministro da Educação cortou as verbas destinadas a este projeto criando assim, um distanciamento com relação às políticas e pesquisas sobre a Educação de Jovens e Adultos no Brasil e desarticulando os programas municipais e estaduais existentes embora a Constituição de 1988, no artigo 208 havia ampliado e garantindo importantes avanços no campo da Educação de Jovens e Adultos.

No artigo 208 da Constituição constata-se que: O dever do estado com a educação será efetivado mediante a garantia de: I - ensino fundamental obrigatório e gratuito, assegurada, inclusive sua oferta gratuita para todos os que a ele não tiverem acesso na idade própria.

Embora a Constituição Brasileira assegurasse a obrigatoriedade de 'Educação para todos', houve retrocesso no processo da Educação de Jovens e Adultos pelas esferas governamentais permanecendo em níveis inferiores aos demais níveis educacionais.

A Lei de Diretrizes e Bases da Educação Nacional nº 9.394 promulgada e sancionada em 20. 12. 1996 pelo Presidente da República Fernando Henrique Cardoso determina na Seção V da Educação de Jovens e Adultos dois artigos que promovem uma ligeira recuperação:

*Art. 37 A educação de jovens e adultos será destinada àqueles que não tiverem acesso ou continuidade de estudos no ensino fundamental e médio na idade própria. 
- $1^{\circ}$ Os sistemas de ensino assegurarão gratuitamente aos jovens e aos adultos, que não puderem efetuar os estudos na idade regular, oportunidades educacionais apropriadas, consideradas as características do alunado, seus interesses, condições de vida e de trabalho, mediante cursos e exames.

- $2^{\circ} \mathrm{O}$ poder público viabilizará e estimulará o acesso e a permanência do trabalhador na escola, mediante ações integradas e complementares entre si.

* Art. 38 Os sistemas de ensino manterão cursos e exames supletivos, que compreenderão a base nacional comum do currículo, habilitando ao prosseguimento de estudos em caráter regular.

- $1^{\circ}$ Os exames a que se refere este artigo realizar-se-ão:

I No nível de conclusão do ensino fundamental, para os maiores de 15 anos;

II No nível de conclusão do ensino médio para os maiores de dezoito anos.

- $2^{\circ}$ Os conhecimentos e habilidades adquiridos e pelos educandos por meios informais serão aferidos e reconhecidos mediante exames.

Embora seja a Lei de Diretrizes e Bases de Educação Nacional 9394/96 o suporte norteador das Bases Educacionais que asseguram o direito a escolaridade a todos os cidadãos, a própria lei apresenta a Educação de Jovens e Adultos como modelo supletivo e assim, descomprometendo o estado da obrigatoriedade de criar condições de permanência dos jovens e adultos trabalhadores no Sistema Educacional, reservando ao Sistema Público, no que concerne ao Exame Supletivo apenas a avaliação do produto, restringindo-se a certificação.

Em 10 de maio de 2000, o Conselho de Educação Básica emite o Parecer Nº 11/ 2000 para a Educação de Jovens e Adultos, de acordo com o Parecer, são estabelecidas quatro funções próprias da Educação de Jovens e Adultos, divididas em:

1. Função Reparadora: “é uma oportunidade concreta de presença de jovens e adultos na escola [...] é por isso que a Educação de Jovens e Adultos necessita ser pensada como um modelo pedagógico próprio."

2. Função Equalizadora: "Para tanto são necessárias mais vagas para estes novos alunos e novas alunas, demandantes de uma nova oportunidade de equalização".

3. Função Permanente: “[...] atualização de conhecimentos por toda a vida [...] é o próprio sentido da Educação de Jovens e Adultos.”

4. Função Qualificadora: "É um apelo para as instituições de ensino e pesquisa no sentido da produção [...]."

Neste sentido cabe enfocar que a organização curricular da Educação de Jovens e Adultos de acordo com o Parecer $\mathrm{N}^{\circ}$. 11/ 2000, possui um perfil diferenciado dos demais educandos devendo ser considerado que:

[...] o importante a considerar é que os alunos da Educação de Jovens e Adultos são diferentes dos alunos presentes nos anos adequados à faixa etária. São jovens e adultos trabalhadores, maduros com larga 
experiência profissional [...] com um olhar diferenciado sobre as coisas [...] logo, aos limites impostos pela vida, não se podem acrescentar outros que signifiquem uma nova discriminação destes estudantes como a desbanalização da regra comum da Lei de Diretrizes e Bases.

Neste contexto, cabe frisar as colocações estabelecidas no Relatório para a UNESCO da Comissão Internacional sobre Educação para o Século XXI (Delors: 2000) quando salienta que os programas de educação básica e de alfabetização para adultos serão mais atraentes se associados a aquisição de competências e se forem utilizados os meios de comunicação social para contribuir no desenvolvimento da aprendizagem.

Assim, Delors (2000, p.cxxxi-ii) aponta que:

É preciso ter em conta as especificidades da vida no meio rural e urbano, decidindo qual a língua de ensino e analisando com cuidado, as adaptações a fazer nos programas, conteúdos, formação de professores e materiais.

Delors (2000, p.133) também faz menção à responsabilidade e ação vigorosa do Estado em relação ao processo de educação destacando que: "Os adultos tenham acesso às possibilidades de aprender para melhorar a sua atividade profissional como a qualidade de suas vidas."

Deste modo, para que se desenvolva um projeto sustentável na Educação de Jovens e Adultos a prática pedagógica deverá oportunizar o desenvolvimento de competências e permitir a estes alunos jovens e adultos, avanços qualitativos que impliquem vivenciar e interpretar sua vida, seus projetos, sua história.

A Lei de Execução Penal é explícita quanto à obrigatoriedade dos presídios, penitenciárias, Casas de Detenção..., oportunizarem a seus detentos condições de reeducação, reinserção e ressocialização.

A referida Lei na Seção V Da Assistência Educacional, no Artigo 17 da Lei de Execução Penal (LEP) determina que: "A assistência educacional compreenderá a instrução escolar e formação profissional do preso e do internado".

Os escritos de Mirabette (1993: p.lxxxv) oportunizam o esclarecimento do Artigo 17 (da LEP):

A assistência educacional deve ser uma das prestações básicas mais importantes não só para o homem livre, mas também àquele que está preso, constituindo-se, neste caso, em um elemento de tratamento penitenciário como meio para a reinserção social ... Dispõe, aliás, a Constituição Federal que a 'educação, direito de todos e dever do Estado e da família, será promovida e incentivada com a colaboração da sociedade, visando ao pleno desenvolvimento da pessoa, seu preparo para o exercício da cidadania e sua qualificação para o trabalho". (art 205), garantindo ainda o "ensino fundamental", obrigatório e gratuito, inclusive para os que a ele não tiveram acesso na idade própria"(art. 208, I), conceituando este como "direito público subjetivo"(art 208, § $\left.1^{\circ}\right)$. Isto quer dizer que não só a instrução, que é um dos elementos da educação, mas também esta é um direito de todos, sem qualquer limitação de idade.

Assim, pois, qualquer pessoa, não importa a idade e tampouco a sua

condição ou status jurídico., tem o direito de receber educação desde que, evidentemente, seja dela 
carente qualitativa ou quantitativamente. De vez que a cada direito corresponde um dever, é a própria Constituição que esclarece ser este do Estado, que deverá promover a educação aos presos e internados se não o tiver feito convenientemente no lar e na escola.

A aprendizagem na prisão por meio de programas educativos se considera uma ferramenta para a mudança de valor e se dá a luz da sua repercussão na reincidência, a reintegração e, mas concretamente, nas oportunidades de emprego após a saída da prisão. A educação é muito mais importante que uma ferramenta para a mudança. É um imperativo em si. A educação apresenta desafios consideráveis para os reclusos devido a uma gama de fatores ambientais, sociais, institucionais e individuais.

\subsubsection{A EDUCAÇÃO PRISIONAL NOS ESTADOS UNIDOS}

Os Estados Unidos da América são um bom exemplo da falência das políticas repressivas neoliberais. Desde o governo de Regan, que se assistiu a um crescente movimento no sentido de privatizar as prisões e os vários sistemas de segurança. Esta tendência para transformar as polícias e as prisões em negócio apetecível ao mercado, foi acompanhada de uma intensificação crescente das penas e da repressão, em quase todos os Estados dos EUA. A pena de morte passou a ser um recurso cada vez mais freqüente, sendo cada vez mais aplicada em alguns Estados, como o do Texas e Califórnia.

As prisões estaduais funcionam com mais $16 \%$ de presos do que o permitido pela sua lotação. As prisões federais estão piores, pois superam essa capacidade em 31\%. Nos Estados Unidos, em 2001, existiam 6,6 milhões de americanos nas prisões ou em liberdade condicional. Isto significa que em dez anos, o número de presos nas cadeias aumentou em dois milhões. Os Estados onde o número de presos aumentou mais foram os do Texas e da Califórnia, isto é, aqueles que mais aumentaram o peso das penas, aplicaram mais a pena de morte fez crescer a violência criminal, e mais, privatizaram o sistema prisional.

Mais de metade dos presos americanos são condenados por terem praticado atos de violência: assassinatos, violação e roubo. O sistema repressivo não é igual para todos, tal como o não são os problemas sociais e as condições de vida. $46 \%$ dos presos são negros, $36 \%$ brancos e $15 \%$ hispânicos. Já no que concerne à liberdade condicional, o mercado repressivo, é mais brando para os brancos do que para os negros. 55\% dos condenados a beneficiarem de liberdade condicional são brancos e apenas $31 \%$ são negros.

O capitalismo é um sistema cheio de manchas. O sistema repressivo é uma delas. Um sistema a exigir uma discussão e análise tão profunda como a que se exige para os sistemas educacionais ou de saúde.

O sistema prisional dos Estados Unidos tem seus alvos. As minorias são as mais afetadas. Seus "clientes" são basicamente pobres, negros e latinos (rabble class). Os negros representam a minoria da população, mas são a maioria dentro dos presídios. Um de cada 19 homens negros está na prisão. Enfim, segundo John Irwin, "o encarceramento serve para governar a ralé."

As penitenciárias americanas como a de Beaumont, Lompoc e Florence, situadas no Texas, Califórnia e Colorado, respectivamente, funcionam como depósitos de gente. Muitos dos condenados estão nas cadeias por terem cometido crimes sem gravidade, onde se poderiam aplicar sanções alternativas.

Nos Estados Unidos, as taxas de encarceramento deram um salto a partir de 1973, no governo de Richard Nixon. No início da década de 70 eram em média 100 presos para 100 mil habitantes. Em 2003, as taxas 
saltaram para 740 presos para 100 mil habitantes. No ano de 1997 , eram 1.785 .079 detentos em todo o país; hoje são mais de dois milhões. Os EUA têm a maior população carcerária do planeta.

O Direito Penal, um subsistema de controle social, vem sendo implementado como um "Direito Penal do Terror", que apenas pune as classes menos favorecidas. Enfim, criminaliza a miséria. É importante ressaltar que a excessiva rigidez na aplicação das penas tem o apoio da maioria dos americanos. No caso da pena de morte, pesquisas afirmam que 70 a $80 \%$ dos americanos são a favor deste sistema racista e cheio de falhas.

Os Estados Unidos gastam mais no sistema prisional do que na educação. Boa parte do orçamento federal vai para a construção e manutenção das prisões Supermax (segurança máxima). A Califórnia, o estado com a maior população penal em todo o mundo ocidental, gastou, de 1997 a 2000, cerca de 5,2 bilhões de dólares na construção de novas penitenciárias. Entretanto, seu sistema penitenciário continua sendo o mais aglomerado nos Estados Unidos, além de um exemplo de desrespeito aos Direitos Humanos, o que torna a ressocialização um ideal quase inalcançável, um mito.

Uma revisão orçamentária com uma melhor destinação dos recursos e um eficaz treinamento policial seria um passo na longa jornada de mudança nos índices de criminalidade e de encarceramento, pois em estados como a Califórnia, a qualidade do ensino despencou desde a adoção do modelo "tudo penal". Portanto, acredita-se, ainda, que a criminalidade, antes de ser punida possa ser prevenida.

\subsubsection{A EDUCAÇÃO PRISIONAL NA EUROPA}

A inserção da educação no sistema prisional surge na França e na América do Norte, previam em suas propostas administrativas a disposição de instrutor/professor aos internos das maiores penitenciárias do país. Os Quackers, grupo religioso que organizaram as primeiras penitenciárias nos Estados Unidos, final do século XVIII, tinham como meta alfabetizar os internos para que pudessem ler a bíblia e, portanto, participar dos cultos religiosos, obrigatórios naquelas instituições penais. A religião, a leitura da bíblia e a participação nos cultos religiosos eram obrigatórias nas penitenciárias americanas.

No artigo "Estratégias sociais e educação prisional na Europa: visão de conjunto e reflexões" do Professor HUGO RANGEL, da Universidade de Quebec e Montreal, Canadá, ele expõe a educação prisional na Europa.

Na Europa, numerosos países aprovaram leis que garantem o direito dos presos à educação. Essas normas legais apresentam geralmente muita semelhança, embora, principalmente nos países do Leste europeu, observe-se uma distância considerável entre o que prescrevem as leis e a vida cotidiana nas prisões. Países como a Bulgária, por exemplo, adotam sistemas rígidos, altamente normativos. Em todos os países, nota-se o crescimento significativo do número de detentos, o que acarreta incontáveis problemas no que tange à aplicação das normas. Além disso, poucos são os recursos destinados a atender às demandas de educação dos presos.

Como mencionou MacDonald (2003), os países da Europa do Leste dão pouquíssima importância às prisões; seus responsáveis políticos concentram esforços em apenas alguns padrões, visando à adesão do seu país à Comunidade Européia, mas as políticas penitenciárias não mudaram na essência e as condições dos detentos continuam precárias. Seria necessário, então, pensar em estratégias globais capazes de 
traduzir as leis e os regulamentos em práticas e em programas. Uma visão de conjunto da educação nas prisões europeias permite identificar várias problemáticas na realidade muito complexa e diversificada da vida carcerária. Essa complexidade obriga-nos a ser vigilantes, a fim de não cairmos na formulação de generalizações.

Nesse sentido, é preciso levar em consideração as diversas dimensões das práticas educativas que estão ou deveriam estar sendo desenvolvidas na prisão, situando suas exigências específicas numa visão mais ampla dos sistemas de justiça e de administração dos programas educativos. A complexidade do meio carcerário, sua natureza multidimensional, a importância dos contextos socioeconômicos e o espírito crítico com o qual devem ser abordadas as práticas educativas permitem-nos afirmar que o discurso das best practices, muito em moda nos meios penitenciários, é incompatível com a realidade da educação prisional. Esse discurso comporta riscos, pois veicula uma ingenuidade a crítica que negligencia os contextos e os problemas sistêmicos.

Um olhar comparativo sobre a educação prisional na Europa obriga-nos a afirmar que não existem fórmulas ou modelos a serem seguidos. Daí decorre a importância de valorizar as práticas educativas numa perspectiva geral. Uma das constatações da pesquisa realizada é que boa parte do "sucesso" de certos programas educativos depende da implementação simultânea de diferentes estratégias, tanto no plano da administração judiciária como no acompanhamento dos detentos após sua liberação. $\mathrm{O}$ "sucesso" dos programas educativos adotados nas prisões pelos países escandinavos pode, a nosso ver, ser explicado a partir dessa leitura e, é claro, de programas sociais que seguem uma estratégia social e comunitária fora da prisão.

Organizando-se serviços e ficando-se atento à população de risco, tem-se a melhora das condições de vida e evita-se a repetição do círculo (infernal) prisão-marginalidade-recidiva. Um modo de melhorar a educação nas prisões é trabalhar também fora dos muros, no âmbito comunitário. Saliento que as administrações dos países escandinavos têm como preocupação a formação dos detentos para a autonomia, inclusive nos atos da vida cotidiana. Essa dimensão educativa, por dirigir-se a pessoas frequientemente dependentes, deveria ser generalizada e fundamentar os programas educativos. Se o objetivo é que os detentos possam superar sua condição, não se deve habituá-los à vida carcerária (a serviços de cozinha e de limpeza, por exemplo). Poder apresentar uma gestão eficaz das prisões e dedicar atenção aos detentos depende também do nível de estabilidade da população carcerária.

A Europa beneficiou-se, nos últimos tempos, de uma estabilidade em suas taxas de encarceramento. Mas, como já foi mencionada, essa situação está mudando: a Alemanha, a Inglaterra, os Países Baixos e, particularmente, a Espanha tiveram taxas de crescimento importantes das suas populações carcerárias ao longo destes últimos anos. A Espanha duplicou sua população carcerária desde 1990, e atualmente a taxa de detentos por 100 mil habitantes é de 146, a mais alta da Europa. A superpopulação, como se sabe, provoca numerosos problemas e acentua os que já existem. Freqüientemente, e cada vez mais se acentuando, as políticas de encarceramento estão ligadas a uma visão punitiva e securitária, produzindo mais problemas do que soluções. Nessa situação, a educação fica em segundo plano, sendo muitas vezes cortada ou reduzida nas prisões superpovoadas.

Quase todos os países que têm leis ou regulamentos prevendo e garantindo o direito à educação na prisão aceitam geralmente que esses direitos sejam implementados por organizações não-governamentais. Todavia, verifica-se com excessiva freqüência que tais iniciativas se limitam a uma visão da educação 
como intervenção terapêutica ou de reabilitação ou, pior ainda, a um tratamento especial para os detentos. É muito raro constatar que as autoridades nacionais consideram a educação prisional um direito universal, embora essa opção lhes pudesse conferir uma legitimidade internacional e reforçar a coesão nacional.

Essa ausência de estratégias nacionais no que se refere à educação prisional foi identificada com frequiência na pesquisa. Conclusões similares foram enunciadas por comissões parlamentares, tanto na Inglaterra como na França, salientando a ausência de coordenação das políticas e das instituições governamentais no desenvolvimento de estratégias para a educação prisional e assinalando a impossibilidade, muitas vezes, de identificar responsáveis públicos. Volta e meia, reina certa confusão quando se trata de designar o organismo responsável pela educação prisional: o ministério da justiça ou o da educação, ou organismos de formação para ao trabalho etc.

Essa confusão é produto ou expressão de uma falta de vontade política? Os centros penitenciários ficam enredados nessa indefinição institucional. Eles administram as urgências com um financiamento insuficiente e, na falta de interlocutor público, vêem-se empurrados para a improvisação.

\subsubsection{A EDUCAÇÃO PRISIONAL NA AMÉRICA LATINA}

A Justiça penal na América Latina continua seletiva na punição. Acostumou-se a mandar para trás das grades os miseráveis que formam maioria absoluta nas prisões e nelas se amontoam em números superiores aos padrões recomendados pelas Nações Unidas (ONU). Pelo menos $70 \%$ dos detentos são provenientes de famílias que sobrevivem com apenas um salário mínimo ( 83 dólares por mês). O perfil dos encarcerados pobres não pára aí: $91 \%$ dos presos não têm instrução primária completa e muitos não sabem sequer escrever o próprio nome. Num conjunto de 10 condenados pela Justiça criminal, 7 deles estão na faixa de idade inferior a 25 anos. Metade da população carcerária na América Latina é constituída de negros. As prisões superlotadas funcionam como mecanismo propulsor de tendências criminosas que, além de contaminar os presos, contagiam os operadores do Sistema Penal e até mesmo a população em geral. O custo de um preso, por mês, corresponde ao dobro do que o Governo gasta, mensalmente, para manter uma criança na escola.

Em termos de proteção aos direitos humanos do preso, nenhum país da América Latina cumpre as normas do Pacto Internacional dos Direitos Civis e Políticos, ditadas pela Organização das Nações Unidas (ONU) em 1966, nem tampouco a Convenção Americana sobre Direitos Humanos, conhecida como Pacto de San José de Costa Rica, aprovada pela Organização dos Estados Americanos (OEA) em 1969.

São quatro os pontos que merecerem consideração de análise.

O ponto de partida, no conjunto dessas inquietações, reside na atmosfera da preocupação com o crescimento da violência na sociedade, alarmada com a insegurança pública recrudescida, de modo impressionante, pelas formas tradicionais e inusitadas de expressões de crimes. Daí o discurso da lei e da ordem, galgado na concepção ideológica que defende a política conservadora de construir mais prisões e fixar penas mais longas, por entender que o número de pessoas inclinadas a cometer crimes decresce, quando o instrumento da punição aumenta.

O segundo ponto é a constatação da inoperância radical da administração penitenciária aliada à notória tibieza do Poder Judiciário diante da ciranda do crime. Nas cidades do Rio de Janeiro, São Paulo, Buenos 
Aires, Assunção, Bogotá, Lima, Caracas e La Paz, cerca de $71 \%$ dos egressos de prisões voltam a elas, por qualquer razão pessoal ou social. Outras cidades, que apresentam menor índice, estão por volta dos $55 \%$, o que também é absolutamente inaceitável. O crime organizado continua arquitetado nas prisões, e chega a constituir, em certos lugares, um poder paralelo, capaz de se confrontar com os órgãos públicos de repressão, não apenas no uso da força, mas também no domínio de tecnologias modernas, como o aberto uso de telefone celulares pelos presos.

O terceiro ponto é o escândalo diário do absoluto descaso pelos direitos humanos dos presos. Embora também exista o outro extremo de privilegiar o preso em detrimento das vítimas, é fato consumado que os Países da América Latina apresentam uma das imagens mais negativas no mundo em termos de tratamento prisional, colhendo com isso a reação ainda mais violenta por parte de organizações não governamentais, cientistas e especialistas dedicados à questão.

O quarto ponto refere-se ao modelo prisional Latino-americano, de modo geral totalmente arcaico, porque ainda encerrado no âmbito da mera repressão praticada na época colonial que, sem estratégias modernas de políticas públicas, vende a falsa ilusão de que o sistema penal funciona enchendo as prisões. A teoria penal está, assim, a serviço da autoridade: o cárcere vale como reafirmação da ordem jurídica, e não como pedagogia da recuperação para proteger a cidadania e alterar a personalidade do condenado, na redefinição de sua escolha existencial.

Duas são as fontes geradoras dessa insegurança.

De um lado, na primeira fonte, existe o pesadelo socioeconômico de base. Na América Latina, a grande maioria da população é constituída de pobres. O Informe Mundial sobre Riqueza, divulgado em Nova Iorque, em junho de 2002, mostra que na América Latina somente 8\% são ricos, sendo a base da pirâmide social constituída cada vez mais de pobres, muitos dos quais apelam ao crime ou à contravenção para sobreviver. Nessa realidade conflitual, o fenômeno mais conhecido é o das crianças e adolescentes sem ocupação que perambulam pelas ruas, pedindo dinheiro, orientados pelas próprias famílias para, desse modo, prover o sustento. Eis a fonte do índice elevado da delinquência que alimenta o arsenal de táticas urbanas de sobrevivência.

De outro lado, na segunda fonte geradora da insegurança prisional, aparece o crime organizado de acesso facilitado ao lucro, ao enriquecimento ilícito e outras vantagens, como, por exemplo, o apoio da corrupção. Assaltos a bancos, roubos de carros e mercadorias, contrabando, sequestros para obtenção de significativos resgates e, sobretudo, tráfico de drogas e de armas são exemplos significativos. Existe a profissionalização do crime, não só como atividade comum das pessoas aí envolvidas, mas também pelo uso de tecnologia sofisticada pertinente. As quadrilhas muitas vezes, possuem armas pesadas, dominam sistemas complexos e modernos de comunicação, usam conhecimento atualizado para planejar e realizar as atividades, inclusive com o auxílio da Internet.

No caso do crime organizado é comum a presença de lideranças negativas, entendendo-se por isso pessoas dotadas de marcantes lideranças, capazes de construir um sistema moderno e eficiente de criminalidade, mesmo quando presas. Tratando-se de um mundo extremamente perigoso, impera a seleção dos mais fortes, o que facilita o surgimento de poderes paralelos bem estruturados, sobretudo quando à força se ligam a inteligência e o dinheiro. 
Essas duas fontes geradoras da insegurança priosional na América Latina, isto é, a pobreza e o crime organizado, representam rasgos muito preocupantes no mundo globalizado.

De certa maneira, é possível afirmar que a primeira fonte, vinculada à pobreza, aponta para questões mais estruturais, porque alimentada na miséria do povo, haja vista as lutas sangrentas pela posse de terra. Furtar ou roubar para sobreviver não deveria ser a tônica de uma sociedade dotada de critérios mínimos de democracia e justiça, especialmente num país como o Brasil, que detém economia razoavelmente expressiva, por isso colocada destacadamente no ranking das Nações Emergentes, mas que tem 55\% do seu Produto Interno Bruto (PIB) comprometido com o pagamento da dívida pública.

A criminalização produzida pela pobreza demonstra, mais do que o recrudescimento da insegurança social, a persistência de altíssima concentração da renda beneficiando poucos privilegiados, na ciranda de um mercado financeiro constantemente em turbulência, com elevações das taxas de câmbio, juros altos e parcos investimentos que intranquilizam os cidadãos, geram aumento de impostos e prejudicam o controle da informação, tudo porque as estratégias dos governos na América Latina não têm sido hábeis em promover o desenvolvimento com qualidade de vida, especialmente agora com os efeitos da globalização.

É assim que se mostra, no Continente Latino-americano, a falta de um projeto adequado ao bem-estar do povo, o que implicaria o desenvolvimento qualitativo da educação primária. Mas o que se vê é que apenas cerca de $30 \%$ das crianças que entram no curso primário chegam a concluí-lo e essa situação acaba por contribuir para a precariedade da polícia, recrutada normalmente entre segmentos de jovens econômica e culturalmente mais pobres no conjunto da população.

A segunda fonte geradora da insegurança prisional, ou seja, o crime organizado, tomou ultimamente dimensões aterradoras, em particular pela capacidade de dispor de recursos e tecnologias expressivos, colocando o aparato repressivo público na defensiva. O que mais preocupa, certamente, é a tendência ao incontrolável, em face à ascensão desse Estado Paralelo, que movimenta milhões de dólares, sabe jogar com a impunidade e acha que o crime sempre compensa, já que seus riscos podem ser calculados e controlados com certa precisão.

Em todos os grandes centros urbanos dos países da América Latina (citem-se os exemplos de São Paulo, Rio de Janeiro, Buenos Aires, Assunção, La Paz, Bogotá e Caracas) há favelas em que a Polícia não entra ou, quando entra, já está em franca desvantagem ante os delinquentes bem armados. Há favelas em que os moradores estão reféns do Estado Paralelo, que vende proteção, obrigando as pessoas a comprar a segurança marginal para poupar a própria vida. Há favelas onde os moradores vêm abandonando suas casas, expulsos delas pelo medo, pelo terror e pela desproteção absoluta a que estão expostos. Há favelas onde o tráfico de drogas prende, julga e executa. Uma pesquisa patrocinada pela Organização Internacional do Trabalho (OIT), em novembro de 2001, revela que a média para ingresso no crime, na América Latina, era de 15 a 16 anos, no início da década de 90, mas, atualmente, esse índice caiu para 12 a 13 anos, exatamente porque o recrutamento de crianças e adolescentes aumentou consideravelmente com as ações dos traficantes, substituindo a ausência de investimentos sociais do Estado Legal.

Na América Latina, a reabilitação prisional, pretendida pela legislação penal, tem patenteado, na prática, o desalento, a aflição e a definitiva rebeldia contra uma sociedade que fecha as portas ao egresso, quando chega o tempo do lendemain de la peine, na elegante expressão dos franceses. 
A prisão continua, assim, a procurar um futuro novo capaz de viabilizar medidas e métodos de execução penal que correspondam aos anseios da reinserção social e moral, em qualquer regime formal de aprisionamento previsto em lei:

a) seja no Regime Fechado para os condenados de maior periculosidade, em estabelecimentos de segurança máxima ou média;

b) seja no Regime Semi-Aberto para os condenados que ficam em semiliberdade, em estabelecimentos de segurança média, que se destinem à prática de atividades agrícolas, industriais ou similares;

c) seja no Regime Aberto para os condenados em estabelecimentos de segurança mínima, adaptados com casas de albergados, onde os presos, teoricamente, podem exercer suas atividades habituais sem qualquer vigilância, recolhendo-se à noite para dormir no albergue com os outros companheiros.

Em nenhum desses três Regimes se cumpre pena com decência e eis a razão pela qual se diz, a todo instante, que a prisão, na América Latina
a) não serve para o que diz servir;
b) oferece o máximo de promiscuidade;
c) neutraliza a formação e o progresso de bons valores;
d) estigmatiza o ser humano;
e) funciona como máquina de reprodução da carreira no crime;
f) introduz na personalidade a nefasta cultura carcerária;
g) estimula o processo de despersonalização;
h) legitima o desrespeito aos direitos humanos;
i) destrói a família do condenado.

Veja-se, por oportuno, que o povo vem assistindo a proliferação de gangues rivais de presos e a ascensão de facções criminosas que comandam operações dentro dos estabelecimentos prisionais, com impressionante capacidade de planejamento e contam com a corrupção dos funcionários do sistema penitenciário para promover fugas, rebeliões, motins, homicídios, suicídios, impor o terror, desafiar o Governo e oprimir a sociedade. É de lamentar que os Governos não tenham boa vontade, nem tenham sido capazes de elaborar e implantar a execução penal com seriedade, determinação e competência.

Preso e sociedade sempre terão de conviver como vizinhos decentes, ainda que estipulando fronteiras. Não precisa ser uma cena de Dostoievski, de irmãos se abraçando, mas uma convivência de compreensão e tolerância, na rota de um consensualismo penitenciário edificado numa escala de valores éticos, morais e normativos, integrado no conjunto da política social do Estado de Direito, em condições de aproximar o delinquente da vida normal dos cidadãos.

A visão global da questão penitenciária nos Países da América Latina, lamentavelmente, está fora de qualquer cronograma usual de planejamento estratégico de promoção social.

Os governantes precisam compreender que o universo penitenciário deve ser visto como componente relevante do moderno desenvolvimento socioeconômico. Faz parte de uma sociedade justa, equitativa, educada e economicamente expressiva saber dar conta desta problemática de acordo com a competência considerada hoje como sendo a atualizada. A violência crescente não agride apenas a cidadania, mas igualmente a economia, como é o caso notório do turismo no Rio de Janeiro e em Buenos Aires. Em 
outro ângulo, a reprodução do crime nas prisões agride totalmente o princípio de mudança radical da concepção atual penitenciária encerrada na prática medieval de prender somente para castigar.

De um lado, deve existir o Estado de Direito, para que se definam os procedimentos legais do crime e da sanção, o que torna a condenação socialmente justa. De outro lado, deve existir a condição iniludível de uma possível e desejável recuperação do preso, sem escamotear o contexto de visível violência aí implicado. Não se trata de esconder a violência, mas de administrá-la em nome da satisfação que o preso deve dar à sociedade em nome de sua necessária recuperação.

Aí está um ponto essencial: quando se trata de recuperação prisional, a melhor maneira de fazê-lo não é com a acentuação da violência. Assim, em ambiente de violência típica, como é o da privação da liberdade, é preciso administrá-la de modo a reduzir essa violência ao mínimo, para sobressair a face da reconstrução do direito à liberdade.

No alinhamento de uma execução penal em busca de elevado significado ao controle jurídico-penal, com equilíbrio e autoridade responsável, se destaca, como ponto alto, o empreendimento do trabalho produtivo e do ambiente educativo.

Não comporta o trabalho apenas como passa-tempo, faz-de-conta, porque não é pedagógico e não é fonte geradora de condições de vida para o dia em que a liberdade chegar. Pedagógico é o trabalho que fundamenta a dignidade da pessoa como ente capaz de prover sua subsistência com autonomia e criatividade. É essencial que o preso tenha a experiência construtiva de que é possível sobreviver sem agredir os outros, por conta da capacidade própria de encontrar soluções adequadas.

Ganhar percentual do valor de seu trabalho é indiscutivelmente um direito humano do preso, até porque aí entra a questão complexa do sustento de sua família.

Acresce ainda a preocupação justa em torno da manutenção das penitenciárias, a qual, pelo menos em parte, deveria ser provida pelos próprios presos. Seus custos são muito altos e tornam-se alucinantes, quando se pensa que são, na maior parte, em vão. Evitando-se sempre o trabalho forçado, definido como espoliativo e desumano, o preso deve trabalhar também para manter a instituição que ocupa, embora sempre em ambiente educativo. Isto quer dizer que o trabalho precisa representar atividade séria para fundar a dignidade da cidadania de alguém que encontra aí ocasião e motivação para mudar de vida.

O ideal seria que a ressocialização do preso fosse apropriada a cada perfil de condenado. Ressocialização significa fornecer ao preso um canal pelo qual possa reentrar na sociedade com escolaridade e desenvolvimento de uma habilidade profissional, que leve em conta as necessidades futuras. Porém, hoje, na América Latina a situação é esta:

- $45 \%$ dos presos não têm nenhuma atividade que exija habilidade ou formação profissional;

- 36\% dos encarcerados se ocupam apenas com o trabalho de serviços gerais dentro da própria prisão;

- $19 \%$ dos detentos dispõem, efetivamente, de um trabalho produtivo com caráter ressocializador.

É interessante assimilar que, na quase totalidade dos Sistemas Penitenciários latino-americanos, e aí se inclui o Brasil, existe uma lei determinando que através do trabalho o preso diminua sua pena: para cada 
três dias trabalhados, abate-se um dia de pena. Como a maioria dos detentos não trabalha, essa lei existe sem maior efetividade.

Na quase totalidade dos sistemas penitenciários, a regra é remunerar o trabalho do apenado com a metade, ou três quartos de um salário mínimo. No Brasil, pela atual Lei de Execução Penal (art. 29) o trabalho do preso será remunerado, não podendo ser inferior a três quartos do salário mínimo (hoje, o salário mínimo equivale a 83 dólares por mês).

Neste contexto, aparece sempre a discussão em torno da atuação da iniciativa privada em estabelecimentos prisionais, havendo nos Estados Unidos e na Europa, já há alguns anos, experiências que parecem positivas. Em si, esse tema não deveria causar espécie, se os objetivos podem ser alcançados com melhor resultado pela via privada. Com efeito, hoje, a situação de absoluta precariedade de, praticamente, todas as penitenciárias as leva a serem confundidas dentro do espírito predominante no serviço público, considerado sempre coisa pobre para pobre. Se os órgãos públicos não são satisfatórios em seus serviços e atividades, em muitos casos a iniciativa privada pode representar a vantagem de executar melhor esses serviços e ainda reduzir custos.

A título de ilustração, mencionamos que acabam de ser implantadas as primeiras prisões privadas na América Latina. Elas estão no Brasil. A primeira, localizada no Município de Guarapuava, no Estado do Paraná, onde os 350 presos têm de estudar e trabalhar na agricultura. A segunda, localizada no Município de Juazeiro do Norte, no Estado do Ceará, onde os 300 presos se dedicam ao trabalho de fabricação de jóias.

Outra opção que se examina para instalar na América Latina, com apoio do gerenciamento do Mercado Comum dos Países do Mercosul (os Países que formam o Mercosul são: Argentina, Bolívia, Brasil, Chile, Paraguai e Uruguai) é a experiência com cooperativas de presos e ex-detentos, as quais, pela influência do bom exemplo, na exploração de atividades econômicas, no campo da agricultura e da indústria, podem ter aptidão para subsidiar a incorporação da iniciativa privada nos propósitos de reintegrar o condenado à sociedade, sem que a pena se desmoralize como promessa lírica que não se cumpre.

Componente de primeira linha, ao lado do trabalho produtivo pedagógico, é a ambiência educativa que deve imperar nas penitenciárias. Não se trata apenas de oferecer educação formal, ou seja, apenas o curso primário previsto na Constituição Federal como direito de todos, mas sem de envolver o preso dentro da ecologia da educação, incluindo cultura, lazer, instrução, etc. Ao contrário das condições atuais imperantes, de total degradação humana, deveria emergir o lado sadio, promocional, desafiador da educação crítica e criativa, uma das bases mais seguras da formação da cidadania popular.

O preso deve ter oportunidade de ler conteúdos interessantes, ver materiais eletrônicos pertinentes de teor didático e instrutivo, discutir temas coletivamente, problemas e soluções, fazer cursos à distância, sobretudo plantar o convencimento da capacidade de se modular como sujeito social competente. Isso supõe metodologias didáticas modernas construtivas, que não se bastam com mera reprodução do saber, imitação, cópia, instrução. O ambiente deve ser marcado nitidamente pelo aprender a aprender, que fundamenta a habilidade crítica e criativa. Assim será possível realizar a função repressiva do Estado de Direito, usufruindo o que a Ciência e a Tecnologia têm a oferecer.

Característica essencial da dinâmica população penitenciária na América Latina é, então, a acentuada 
ausência de instrução escolar sem iniciação e sem aperfeiçoamento técnico, daí a constatação de que:

a) $36 \%$ de presos são analfabetos; e

b) $51 \%$ de presos não têm instrução primária completa.

Esse é um dos fatores incisivos mais indutores de tensões, revoltas, motins e do círculo da reincidência no crime. $71 \%$ das pessoas que saem das prisões, a elas voltam por falta de terapia da reestruturação pessoal, carência que não estimula boas chances no retorno à sociedade.

Anote-se, nesta oportunidade, que o Peru foi o primeiro país da América Latina a colocar em vigor uma lei estabelecendo a compensação da pena pelo estudo: para cada três dias de atividades de educação escolar, abate-se um dia da pena a ser cumprida. Outros países, como o Brasil, já estão regulamentando esse esforço de iniciativa educacional adotado no Peru.

Está bem claro, nesta apreciação, que a conjugação inteligente entre ambiente educativo e o trabalho produtivo pedagógico, lamentavelmente ainda não é o ângulo principal do processo de reconstrução da liberdade e da dignidade dos presos na América Latina. Pouquíssimos bons exemplos podem ser observados e entre esses pouquíssimos bons exemplos, destacamos a experiência que situamos a seguir.

Há expectativa de mudanças? Apesar de tudo, vale a pena manter o entusiasmo e a grandeza de espírito, na luta pelo comprometimento social com a educação e o trabalho no ambiente que consome os valores da vida carcerária.

Um dia ficaremos livres da frieza e da carência de zelo cívico tão comum entre os políticos que hoje governam os países da América Latina. Esses governantes perturbam os nossos sonhos, mas, pelo menos, não são capazes de nos deixar sem a consciência tranquila e não nos tiram a capacidade de esperar.

Seria mais triste ainda viver se a esperança não pudesse vencer o medo das incertezas.

\subsubsection{A EDUCAÇÃO PRISIONAL NO MERCOSUL}

Rege a Declaração Universal dos Direitos Humanos: "Ninguém será submetido à tortura nem a tratamento ou castigo cruel, desumano ou degradante".

Estes Tratados, Pactos e Convenções fazem parte dos ordenamentos jurídicos nacionais dos Estados, e são fontes soberanas de direito público, de plena e irrestrita vigência interna.

As normas definidoras dos direitos e garantias fundamentais têm aplicação imediata, isto é, são autoaplicáveis. Desta forma, os direitos e garantias não excluem outros decorrentes do regime e dos princípios adotados pelo governo brasileiro e constante nos tratados internacionais (Constituição da República Federativa do Brasil, parágrafos $1^{\circ}$ e $2^{\circ}$, art. $5^{\circ} \mathrm{CF}$ ).

Nesse sentido, a Convenção de Viena, sobre Direito dos Tratados, de 1969, em seu artigo 60, prescreve como obrigação "erga ommes" que não se podem usar subterfúgios e invocações do direito interno para justificar o não-cumprimento de um Tratado aderido, nem a Constituição pode, contradizer norma de Direito Público humanitário, vez que possui caráter imperativo ("ius congens") e não simples disposição. 
Os Estados devem fazer valer a salvaguarda dos interesses comuns superiores protegidos pelas Convenções, para não afetar o seu próprio grau de validade hierárquica, sob forma de restrição ou de rebaixamento, mas sim, para aumentar os mecanismos de supervisão e respeito a um tratamento humano mínimo (ver Cançado Trindade, Antonio Augusto; in Direito Internacional Humanitário, IPRI, Brasília 1989).

Dentre os Direitos Humanos dos presos, por exemplo, dispõe a Lei de Execução Penal brasileira ( $\operatorname{art.~} 1^{\circ} \mathrm{e}$ 10) que a sentença ou decisão criminal tem por objetivo proporcionar condições para a harmônica integração social do condenado e do interno, e que a assistência material, à saúde, jurídica, educacional, social e religiosa, é dever do Estado, para prevenir o crime e orientar o retorno à convivência do apenado em sociedade. Teoria do "res", segundo E.Raúl Zaffaroni, como justificativa ao encarceramento humano e restrição ao "ius libertatis".

"Nenhuma pessoa submetida a qualquer forma de detenção ou prisão será submetida à tortura ou a tratos ou penas cruéis, desumanas ou degradantes. Não se poderá invocar circunstância alguma como justificação da tortura ou de outros tratos ou penas cruéis, desumanas ou degradantes", estatui o princípio (6) do Projeto de Conjunto de Princípios para a Proteção de todas as pessoas submetidas a qualquer forma de detenção ou prisão da ONU (Resolução n. 43/173).

A expressão "tratos ou penas cruéis, desumanas ou degradantes" deve ser interpretada de maneira que abarque a mais ampla proteção possível contra todo tipo de abuso, sejam físicos ou mentais, incluído o de manter o preso ou detento em condições que o privem temporária ou permanentemente do uso de um de seus sentidos, como a visão ou a audição, ou de sua ideia de lugar ou do transcurso de tempo. (in La Revista, Por el Império del Derecho, da Comisión Internacional de Juristas, n. 42, Junio 1989).

O contido no artigo $1^{\circ}$ Convenção Contra a Tortura da ONU, e dispositivo $2^{\circ}$ da Convenção da OEA, rezam que "as dores e os sofrimentos por consequiência de sanções legítimas ou "medidas legais", não estão compreendidos no conceito de tortura". Obviamente que devemos interpretar no sentido de que, desde não afetarem os princípios humanitários básicos. De outro lado, a execução da pena privativa de liberdade deve observar as Regras Mínimas das Nações Unidas para os detentos, do contrário pode caracterizar a prisão, na prática, pena infamante, cruel e desumana, visto que atenta contra a dignidade da pessoa encarcerada, ferindo inclusive os princípios elementares de justiça de um Estado Democrático de Direito.

Não devemos admitir e legitimar nenhuma das condições degradantes que estão sujeitos todos os presos, a prisão por si só causa dores, sofrimentos físicos e psicológicos nefastos e irreparáveis ao ser humano que o Estado pretende recuperar, ressocializar, reintegrar, reeducar ou readaptar.

Contradições desta ordem e deste nível de desrespeito jurídico e legal não podem existir e ser admitidos pelos Documentos de Direitos Humanos; pois, sem exceção alguma, visam a prevenção e a repressão das violações fundamentais inerentes ao direito de viver com dignidade, seja "intra" ou "extra" "murus".

É público e notório que a maioria, ou quase a totalidade, dos estabelecimentos prisionais da América Latina e do Brasil, efetivamente, tem transformado o cumprimento da pena privativa de liberdade, em sanção cruel e desumana. Ainda que esteja expresso em documento internacional que "nenhum funcionário encarregado de fazer cumprir a lei poderá infligir, instigar ou tolerar nenhum ato de tortura ou 
outros tratos ou penas cruéis, desumanas ou degradantes", reza o artigo $5^{\circ}$ do Código de Conduta para Funcionários Encarregados de Fazer Cumprir a Lei (Adotado pela Assembléia Geral da ONU em 17-12-79 - Resolução n. 34/169).

Segundo a doutrina especializada, a expressão "funcionários encarregados de fazer cumprir a lei" inclui todos os agentes, nomeados ou eleitos, que exercem funções de polícia, com faculdades de arresto ou detenção, incluam-se, a nosso ver, também as autoridades judiciárias, magistrados que determinam a prisão e membros do Ministério Público que requerem a condenação à pena privativa de liberdade ou que postulam a prisão provisória.

Em geral, sabemos que a pena privativa de liberdade teve sua origem na revolução industrial e que seu objetivo foi e é eminentemente utilitário, ainda que o discurso ideológico tenha sido humanitário. Para isso, se faz indispensável o respeito a norma com rigidez em nome do princípio da legalidade.

Seria muito conveniente pensar em algum controle internacional para verificar o grau de cumprimento e de descumprimento das Regras Mínimas das Nações Unidas para Tratamento do Recluso, afirma o prof. Eugênio Raul Zaffaroni, acrescentando: "As condições de alojamento das pessoas privadas da liberdade devem ser vigiadas judicialmente. A indiferença judicial nesta matéria é notável no continente latinoamericano. É preciso ações e recursos de habeas corpus e similares para amparar as condições de alojamento higiênico e digno.

A via mais prática para quebrar a indiferença judicial é responsabilizar em forma pessoal - inclusive penal - os juízes por negligência na vigilância de tais condições. Isto geraria, sem dúvida, conflitos com o Poder Executivo e se alegaria a carência da infra-estrutura para cumprir as "Regras Mínimas" das Nações Unidas. A solução mais prática e adequada aos Direitos Humanos, ante tal conflito, é impor aos juízes o dever de interditar os estabelecimentos inadequados e de dispor a imediata liberdade qualquer pessoa privada de liberdade em condições que não satisfaçam os requisitos mínimos de segurança e higiene. $\mathrm{O}$ Poder Judiciário deve regular com extrema severidade a privação da liberdade quando exista um número de pessoas maior do que o indicado nas condições mínimas de alojamento digno disponível (capacidade conforme a planta arquitetônica).

O processo institucional de prisionalização gera fatores negativos, e estes são originários da: superpopulação; ociosidade; insalubridade e promiscuidade pela falta das mínimas condições de vida com dignidade e precariedade das instalações físicas. A violência física (sexual) e psíquica que estão sujeitos os detentos, a corrupção entre agentes penitenciários e grupos de internos, e muitas outras mazelas são produzidas dentro dos ergástulos públicos (ver CPIs do Sistema Penitenciário da Câmara dos Deputados Federais do Brasil, de 1975 e 1993).

Define a Regra 31 da ONU para Tratamento dos Reclusos, sobre disciplina e sanções: "As penas corporais, encerramento em cela escura, assim como toda sanção cruel, desumana ou degradante são completamente proibidas como sanções disciplinares". Se há previsão legal proibitiva de sanção disciplinar nestas condições, muito mais óbvio e evidente que o Poder Judiciário não pode admitir a execução da pena privativa de liberdade quando caracterize na prática sanção cruel, desumana e degradante.

Sabemos que os maus-tratos carcerários resultam do "modus vivendi" oferecido pelo Estado aos 
condenados à pena privativa de liberdade, que impera a "lei do mais forte" ou a sobrevivência no interior dos estabelecimentos penais.

A regra geral do direito penal democrático é interpretar a lei restritivamente, e quando necessária a ampliação, esta maneira somente é autorizada juridicamente quando for em benefício ou a favor do réu ou do apenado. $\mathrm{O}$ artigo $3^{\circ}$ do Código de Processo Penal, reforça este critério doutrinário, quando estabelece que são permitidas a aplicação dos princípios gerais do direito.

Na legislação brasileira (lei n. 4.898/65) o direito de representação e o processo de responsabilidade administrativa, civil e penal, nos casos de abuso de autoridade, considerando-se crime todo atentado "à incolumidade física do indivíduo" (art. 3, "i"); "submeter pessoa sob sua guarda ou custódia a vexame ou a constrangimento não autorizado em lei" (art. 4, "b"); em reforço a norma ordinária a Carta Magna assegura a concessão de mandado de segurança para proteção de direito líquido e certo..., quando o responsável pela ilegalidade ou abuso de poder for autoridade pública (inciso LXIX, art. $5^{\circ} \mathrm{CF}$ ).

A título de estudo e de informação do direito positivo das Nações Unidas (Assembléia Geral em Resolução n. 40/43, de 29 de novembro de 1985), lembramos a recomendação do Sexto Congresso da ONU sobre Prevenção do Delito e Tratamento do Delinquente (Milão - Itália), para a continuidade do trabalho de elaboração das diretrizes e normas para as vítimas do delito de abuso de poder, solicitando a cooperação de organismos governamentais e não governamentais.

São consideradas "vítimas de abuso de poder" as pessoas que, individualmente ou coletivamente, tenham sofrido danos, inclusive lesões físicas ou mentais, sofrimento emocional, perda financeira ou diminuição substancial de seus direitos fundamentais, como consequência de ações ou omissões que não cheguem a constituir violações do direito penal nacional, mas violem normas internacionais reconhecidas e relativas aos Direitos Humanos (item 18, letra B, da Declaração sobre os Princípios Fundamentais de Justiça para as Vítimas de Delitos e do Abuso de Poder).

Assim, a decisão emanada do Poder Judiciário que fundamentar e aplicar os princípios de direito, supra referidos, estará dentro da mais cristalina legalidade e prestando a mais pura medida de Justiça; "in contrarium sensu", concretizar-se-á uma gritante e brutal inobservância aos Direitos Humanos e aos princípios reitores do regime penal democrático, com flagrante abuso de autoridade passível de responsabilidade, desde a pena administrativa de advertência até a de demissão a bem do serviço público, sem prejuízos da aplicação da sanção civil de indenização e da própria detenção.

O modelo do "homem enfermo", frente ao do "homem normal", é ainda mais torturante e desumano, vez que o Estado não possui pessoal especializado e muito menos estabelecimentos destinados a esta espécie de serviço médico-psiquiátrico. E a possibilidade de defesa é muito mais difícil, pois, os exames "médicos-criminológicos" são estigmatizante e marginalizam eternamente o paciente. São raros os que conseguem um parecer favorável quanto a cura de sua "personalidade criminosa".

Culpabilidade de Autor versus culpabilidade de Ato, onde os réus possuidores de boa ou regular condição financeira são autorizados a frequentar clínicas particulares, já os vulneráveis (pobres) do sistema de administração de justiça penal são internados nos chamados Manicômios Judiciários, com total falta de infra-estrutura, sofrendo diariamente maus-tratos, pela dupla condição de prisioneiro e de enfermo mental. 
Sempre em debate no âmbito dos Direitos Humanos, são colocadas em dúvidas as questões como: choques elétricos e insulínicos, condicionamentos de reflexos inibitórios e, determinados tratamentos para modificar a conduta.

Os princípios básicos de ética médica aplicável à função do pessoal de saúde, especialmente os médicos na proteção de pessoas submetidas a qualquer forma de detenção ou prisão contra a tortura e outros tratos ou penas cruéis, desumanas ou degradantes expressos na Resolução n. 37/194, de 18.12.82, das Nações Unidas, em reconhecimento a Resolução 31-85 de 13 de dezembro de 1976 da Organização Mundial da Saúde, estão sendo violados corriqueiramente pelo Estado e sua administração penitenciária.

À luz dos instrumentos internacionais de Direitos Humanos, de aceitação universal e aderido pelo governo da República Federativa do Brasil, destacamos a Declaração Universal dos Direitos Humanos (1948/ONU); Pacto Internacional de Direitos Civis e Políticos (1966/0NU); Convenção Americana sobre Direitos Humanos (1969 / OEA); Regras Mínimas das Nações Unidas para Tratamento dos Reclusos (1955/57/77); Normas para a aplicação das Regras Mínimas para o Tratamento dos Reclusos (ONU/1984); Princípios Básicos para o Tratamento dos Reclusos (ONU/1990); Conjunto de Princípios para a Proteção de Todas as Pessoas submetidas a qualquer forma de Detenção ou Prisão (ONU/1988); e Regras Mínimas do Preso no Brasil (Ministério da Justiça/1994).

É de se ressaltar que na prática nenhum dos Documentos internacionais, muito menos a Constituição federal e a legislação ordinária positiva (Lei de Execução Penal) não estão cumpridas e respeitadas, dentro da obrigatoriedade dos princípios basilares do Estado de Direito, impõem-se às autoridades competentes e diretamente ligadas a questão prisional do país, seja na esfera do Poder Executivo (encarregadas do gerenciamento do sistema penitenciário), como na alçada do Poder Judiciário (competentes para a execução de medidas privativas de liberdade), responsabilidade criminal, em decorrência da inércia e/ou da prevaricação de atos de ofício que deveriam tomar e não o fizeram em tempo oportuno, conforme prevê o Código Penal (Decreto-lei n. ${ }^{\circ}$ 2.848/40).

Os artigos $1^{\circ}$ e 10 da Lei n. ${ }^{\circ} 7.210 / 84$, estabelecem que a execução penal tem por objetivo efetivar as disposições de sentença ou decisão criminal e proporcionar condições para a harmônica integração social do condenado e do internado. Ao condenado e ao internado serão assegurados todos os direitos não atingidos pela sentença ou da lei.

Carecem os detentos (provisórios e definitivos) do direito à assistência material, ou seja: de alimentação suficiente, vestuário, de atividades laborais (inclusive quanto à remuneração, previdência social e pecúlio, e direito de remição), intelectuais, artísticas e desportivas, à saúde, jurídica, educacional, social e religiosa.

Se a educação pode ajudar a reinserir um preso na sociedade, o Brasil está bem longe dessa meta. O sistema prisional brasileiro abriga 371.400 presos, de acordo com dados preliminares de 2006 do Ministério da Justiça. E menos de 10\% dos presos - 34 mil - completaram o ensino fundamental. Pior: cerca de 18 mil são analfabetos.

A Lei tem número, 7.210, é de 1984, se chama Lei de Execução Penal e é bem clara: determina a oferta do ensino fundamental e a formação profissional nas cadeias. Mas há uma enorme distância entre o que está escrito e o que realmente acontece dentro das prisões. 
O último relatório sobre escolaridade de presidiários, de 2003, faz a lista das maiores barreiras ao ensino nas cadeias brasileiras. Começa pela falta de espaço adequado, segue pela carência de professores e agentes penitenciários e, finalmente, reflete a ausência de um sistema de ensino nacional, vinculado à educação de jovens e adultos.

No Brasil, o MEC e o MJ trabalham juntos desde 2005 para criar uma política pública de educação prisional, com diretrizes nacionais. "Na maioria dos estados, existe educação nas prisões, mas de forma aleatória. Faltam vagas para os alunos interessados em estudar, nem sempre há todos os níveis. Há turmas de alfabetização e ensino fundamental, mas há alunos que gostariam de fazer o ensino médio também", diz Timothy Ireland. Ele conta que muitos presídios não dispõem sequer de espaço físico que comporte salas de aula. "Já vi até um corredor adaptado. A primeira parte era para turmas de alfabetização, a do meio para ensino fundamental e o fundo, para ensino médio. Tudo muito precário."

O diretor do MEC destacou as iniciativas argentinas, que desde 2003 tem uma política pública de educação prisional, segundo ele. "A forma de encarar a questão na Argentina é diferente dos demais países. Em vários, o assunto ainda não constitui uma política pública. Às vezes, [as ações] nem mesmo são feitas pelos governos, mas por ONGs."

A educação deve ser vista como um direito, não para a reintegração. Claro que isso é muito importante, mas se a reintegração for impossível, a educação continua a ser um direito. Não devemos instrumentalizar a educação unicamente para um papel social ou do tipo político-social. A educação pode ser uma solução se for uma educação ao longo da vida, não apenas do tipo profissional ou a reeducação. É para muitos presos a primeira oportunidade de compreender sua história e de tratar de desenvolver seu próprio projeto de vida.

A noção de educação prisional como direito está no auge das discussões em todo o mundo. Em novembro de 2006, por exemplo, o Brasil acolheu, em Belo Horizonte, as discussões do Fórum Educacional do Mercosul, que tinha como um dos núcleos de debates o Seminário de Educação Prisional, que recebeu autoridades neste assunto de toda a América Latina e Europa e de entidades ligadas à educação e direitos humanos. O objetivo era criar uma rede latino-americana de discussões, que colocasse na pauta dos governos de cada país a educação prisional como direito inalienável de todos e as possíveis soluções para tornar essa educação mais proveitosa.

Os especialistas em educação prisional defendem que a escola deve ser um direito mesmo que o detento não seja reintegrado ou reintegrável à sociedade.

No Paraguai segundo dados do Ministério da Justiça e Trabalho nas 15 (quinze) penitenciárias do país o número de presos são 5.889 dados estes de 12 de dezembro de 2008. O Paraguai apresenta uma das mais reduzidas percentagens de presidiários em relação à população (4 mil presos para 5,1 milhões de habitantes). No entanto, a maioridade penal é expressivamente baixa em relação aos outros países do continente: somente são inimputáveis criminalmente os menores de quatorze anos.

Em Tacumbu - maior presídio do país -, é crônico o problema de superlotação. Por absoluta inexistência de espaço físico os presos vão ocupando todos os lugares disponíveis: a capela, a marcenaria, a cozinha, os escritórios administrativos e as dependências de assistência.

São 1,5 mil pessoas aglomeradas, semelhante a um campo de refugiados. Esta grande concentração vem 
acarretando graves problemas de saúde e higiene. Não há incentivo ao trabalho penitenciário. Os telefones públicos, antes disponíveis no interior do presídio, foram barbaramente destruídos para obrigar os reclusos a alugar os aparelhos de telefonia celular daqueles que os possuem. Foram localizados também alguns presos provisórios entre os sentenciados. Um deles aguarda há oito anos decisão de seu processo criminal. A estes, além da ausência de assistência judiciária, não são observadas as orientações normativas de separação dos condenados, oferecimento de oportunidade de trabalho e muitas vezes são proibidas as visitas familiares. Próximo ao presídio de Tacumbu existe o Centro de Reabilitação chamado Panchito López, destinado a menores infratores, que abriga crianças e adolescentes de 14 a 18 anos. São trezentos reclusos divididos unicamente pelo critério de idade, o que expõe os menores a um risco potencial. Nem todas as celas estão em perfeito estado de conservação. O centro de Reabilitação carece de investimentos para ensino educacional e profissionalizante aos jovens de Tacumbu.

No Paraguai registram-se inúmeras queixas sobre a morosidade e a ausência de assistência jurídica. Por fim, constatamos ainda a incrível existência de um presídio fantasma, onde, embora existam diretores designados e previsão orçamentária, as obras para conclusão do presídio encontram-se em completo estado o de indiferença e abandono.

Em 2007 o Ministério da Educação e Cultura do Paraguai através da Direção Geral de Educação Permanente beneficiou com materiais escolares e didáticos cerca de 700 alunos da educação de média distância para jovens e adultos com ênfase para as novas tecnologias e 1000 estudantes da educação básica bilíngue para jovens e adultos. Este projeto é a implementação da Reforma Educativa da modalidade de jovens e adultos que se desenvolve em todo o país, através do Programa de Educação Básica Bilíngue de Jovens e Adultos (PRODEPA).

O objetivo é melhorar a qualidade da educação dos presos e garantir o acesso a educação básica e de nível médio. $\mathrm{O}$ projeto aponta para o funcionamento e consolidação da nova rede de docentes penitenciários que conta com a estrutura e apoio para assegurar o processo de aprendizagem dos internos e a possibilidade de continuar seus estudos quando obtenham sua liberdade.

$\mathrm{Na}$ Argentina, há cerca de 30 mil reclusos, sendo que aproximadamente 6,1 mil pessoas cumpram pena em estabelecimentos federais de Buenos Aires. De acordo com os dados oficiais, apenas $20 \%$ da população carcerária argentina encontra-se contemplada pelo direito ao trabalho penitenciário. É também alarmante a informação de que aproximadamente $8 \%$ dos reclusos estariam infectados pelo vírus da Aids, fato este agravado pela grande incidência de outras doenças sexualmente transmissíveis.

No presídio federal Caseros, em plena Buenos Aires, centenas de presos condenados não têm onde tomar sol ou praticar esportes. Não há a menor perspectiva de trabalho num presídio parcialmente destruído pela última rebelião, ocorrida já há alguns anos.

O melhor exemplo de administração penitenciária da Argentina foi observado em Olmos, próximo a La Plata. Lá encontramos 3.336 internos, dos quais 80\% são sentenciados. Embora a população carcerária seja superior à sua capacidade, Olmos apresenta alguns aspectos positivos: aos detentos são oferecidos serviços de ensino integrado à rede pública educacional. São 180 reclusos matriculados em curso primário e 220 em aulas de orientação secundária. Em todos os pavilhões são encontrados telefones públicos que permitem aos presos o livre acesso a seus familiares e advogados. Um serviço comunitário de rádio opera internamente, ocupando parcialmente a população carcerária. É permitida a visita conjugal aos detentos, 
bem como assistência religiosa. Durante a visita tivemos a oportunidade de presenciar uma cerimônia pentecostal que reuniu cerca de oitocentos detentos.

No Uruguai - bastião do civismo, da melhor distribuição de renda do continente e dos direitos sociais - é o Ministério do Interior responsável tanto pela repressão ao crime e quanto pelo encarceramento, em contradição à regra fundamental de incompatibilidade entre as duas atribuições.

O Complexo Carcerário Santiago Vásquez, que aloja mais de 50\% da população reclusa do país. Constatase o problema de superlotação, já que, originariamente concebido para alojar oitocentos presos, hoje comporta 1,7 mil detentos. Há ainda grande carência em matéria de trabalho, apesar de alguns convênios realizados com empresas privadas. Um problema essencial é a inexistência de hospital penitenciário para atendimento médico, farmacêutico e ambulatorial.

Em muitos países, a remição já é lei há décadas. "Por trás da remição, está o conceito de prisão, que ou tem uma perspectiva de punição ou uma visão de ressocialização. Nós a vemos como forma de reintegrar à sociedade, por isso a educação pode acelerar esse processo de soltura do condenado", diz Hernando Lambuley, chefe da divisão de desenvolvimento social do Instituto Nacional Penitenciário e Carcerário da Colômbia. Na Colômbia, a cada cinco dias de aula, um a menos de pena a cumprir.

No Equador, a conta é sete dias de estudo igual a um de pena cumprida. No entanto, a remição não vale para assassinos e narcotraficantes. "Estes não têm esse direito em função da gravidade do delito", explica Eduardo Chiliquinga, coordenador-geral do Ministério da Educação e Cultura do Equador.

A educação nas prisões acaba de ser incorporada na nova Lei Nacional de Educação Argentina. Lá, o estudo funciona apenas como sinônimo de bom comportamento, mas não há equivalência estabelecida de dias estudados em troca de pena cumprida. "O estudo é valorado como boa conduta, como alguém que está interessado em mudar de rumo na vida”, diz Stella.

O panorama hoje nos mostra uma realidade que desencadeia na reclusão de muitíssimas pessoas que criminalizam suas atitudes, suas intenções, seus atos, seus agires, e desta maneira contaminam outros seres que ficam possuídos pelo medo, esse que é o pior inimigo do homem, esse que não deixa a paz e a segurança interna se desenvolver para impulsionar os desejos particulares e converter-lhes em realidade.

Privações à liberdade ficam ganhando como prêmio pelos seus comportamentos, e a sociedade em geral acredita ser uma bela punição esta perda no direito de ir e vir, pois acontece que o estado em que se encontram os condenados ao cárcere evidencia de por si a carga da pena que desta maneira lhes parece ser el mejor de los castigos, mas esquecemos dos direitos de todos os que são privados da suas liberdades e que merecem, a pesar da sua conduta reprovável e ilegal, um tratamento adequado, pois é letrado no Pacto Internacional dos Direitos Civis e Políticos das Nações Unidas com entrada em vigor na ordem internacional em 23 de Março de 1976:

"Art.10. Todos os indivíduos privados na sua liberdade devem ser tratados com humanidade e com respeito da dignidade inerente à pessoa humana".

Claro que também ficam privados de liberdade, os que foram vítimas destas violações, pois são cada vez mais janelas de carros fechadas, muros mais altos são construídos em casas, mais temores inculcados na infância das nossas crianças, mais alerta de cuidados para aos nossos visitantes vindos de outros países e 
que taxam as nossas belezas como envenenadas pela falta do livre desfrute de quem vem de longe para deixar suas divisas e levar em troca a fama da insegurança total, da pobreza e do despreparo educacional.

Os homens e mulheres de boa fé devem se inter-relacionar em harmonia e com cortesia, e devemos nos esforçar para que nas próximas décadas o nosso país seja reflexo de intenção em um sentido de melhorar tudo o que está se encontrando como desviado e prejudicial para o desenvolvimento de uma humanidade mais consciente das suas atitudes; mais consciente dos limites que a lei impõe para organizar uma sociedade frutífera, produtiva e cheia de possibilidades para todos. Também devemos cobrar ao Estado para que através dos nossos governantes sejam promovidas políticas públicas de inclusão social, que possibilite a todos o mínimo necessário para a formação do cidadão.

Os que entendem que a vida é uma oportunidade que a existência nos dá para o crescimento pelo bem estar, de uma maneira mais consciente com a responsabilidade pessoal e individual como célula da sociedade, figurando-se mais aptos para adquirir tolerância e um entendimento de que as forças devem ser unidas em grupos organizados na comunidade acadêmica que como sementes luminosas, dentro da obscuridade que o crime encerra, se instalem e criem raízes fortes para castrar o crescimento e formação de futuros desgostos.

Nota-se que precisamos de uma estrutura carcerária mais digna como pretende o texto constitucional da ensaiada Constituição para a América Latina e o Caribe, esboçada pelo Movimento Constitucional Latino Americano da Equipe Federal do Trabalho no seu Capítulo IV, Dos Cárceres dignos:

"Art.78. Todos os Estados integrantes da União assegurarão que os cárceres dentro de cada território sejam: sãos, limpos, seguros, tutores do direito à integridade física, psíquica e moral, guardiões da honra e dignidade, patrocinadores dos direitos constitucionais dos internos; educativos, antecipando-se, observando e aplicando obrigatoriamente a estes as ferramentas de socialização e reinserção necessárias. Os cárceres não serão um meio de castigo ou perseguição física, psicológica ou moral para seus internos, nem por parte do serviço penitenciário nem por parte de outros internos. Qualquer violação destes direitos tornará responsável a quem o permitir ou autorizar. "

É dessa responsabilidade que deve estar imbuídos todos os que acreditam em uma filosofia de vida em prol de uma sociedade melhor, de perfil inclusivo e de respeito à dignidade da pessoa humana, é aqui quando temos que assimilar que a capacidade de ler as realidades políticas é vital para a montagem de coligações e redes por trás dos bastidores. Essas redes permitem a alguém exercer influência, independentemente de seu papel profissional. Os que têm um desempenho medíocre carecem dessa acuidade social e por isso revelam um nível tristemente baixo de sabedoria política.

Deve-se buscar estudar as ciências criminais também como uma chave que pode abrir caminhos para parar o sofrimento de muitos que sofrem; buscar uma sabedoria política que deve ser carregada da política da empatia na medida certa para muitos que sofrem como todos nós sofremos pelos infortúnios resultantes na nossa humanidade em geral por causa das escolhas más, das escolhas de seres que geram estados dignos de compaixão e que estão contaminados pelo seu próprio ódio e frustração, e que às vezes, nunca tiveram uma chance de aprender a arte de viver, de viver em paz consigo mesmo e, porém com os outros seres vivos.

Há várias décadas existe uma experiência que é vivida no Sistema Penitenciário da República da Índia , especificamente na prisão de Tihar, Nova Delhi, e em mais de quinze prisões desse país, e mais 
recentemente nesta última década nos países de Israel, no Presídio para Mulheres na Mongólia, em Taiwan, na Espanha, na Grã-Bretanha, nos Estados Unidos, México, Chile e Argentina, sendo que o Brasil já se mostra interessado em também adotar esta, poderíamos dizer, ferramenta de reestruturação do sistema prisional.

As pessoas importantes são os agentes penitenciários que se relacionam com os detentos cotidianamente. São eles que abrem as celas dos detentos pela manhã, que ficam junto deles a maior parte do dia e que os encerram pelas noites. São testemunhas das maiores forças e das grandes debilidades dos detentos. A forma como os agentes penitenciários tratam os detentos determinará se uma prisão é decente e humana, ou brutal e coercitiva. Eles falam com os reclusos habitualmente, seja com respeito ou não, controlam a distribuição das camas e das celas, o acesso às comidas, às visitas familiares, às encomendas, às correspondências, o acesso aos telefones, ao trabalho, à educação, aos médicos e aos traslados para outras prisões.

São os agentes penitenciários que mitigam as desordens potenciais, manejam os incidentes com toma de reféns, fazendo isto de forma violenta ou por médio de uma negociação. Para que os agentes penitenciários tratem bem aos detentos e respeitem seus direitos, é essencial que eles mesmos sejam respeitados e valorizados. Também necessitam se desenvolver dentro de um marco ético claramente estabelecido e valorizado publicamente e que defina os parâmetros das condutas aceitáveis.

A formação e treinamento são necessários para melhorar o profissionalismo e as aptidões dos agentes penitenciários, mas também para deixar em claro que as autoridades superiores considerem que um maior profissionalismo dos agentes penitenciários é um investimento importante. Normalmente quem apóia um projeto de reforma penitenciária soe considerar que dar uma formação adicional aos agentes penitenciários constitui uma das melhores formas de aperfeiçoar a administração das prisões e garantir um maior respeito pelos direitos humanos.

Antes de realizar um curso desta técnica de meditação em um presídio, um profissional veterano da mesma, assim como tantos outros quanto for possível, deve fazer um curso em um Centro de Meditação Vipassana. Este é um pré-requisito essencial.

Isto permite aos agentes penitenciários compreender melhor, graças à experiência direta, o valor e a relevância da Meditação Vipassana em seu centro penitenciário específico. Ao ter participado de um curso, hão de entender melhor como programar um curso dentro das próprias instalações.

Mudar as condutas e atitudes dos agentes penitenciários é chave para o sucesso da reforma penitenciária, assim considerando que a reforma é a solução. Se prestando, também, atenção a outros fatores importantes para os agentes penitenciários, como os são suas condições de emprego e o acesso a diversos recursos como o da possibilidade da formação educativa, intelectual e religiosa que lhes permitam o respeito e a valorização pelos seus direitos e pelos direitos dos demais. Podemos afirmar que a maneira em que os agentes penitenciários tratam os detentos é fundamental para o respeito dos direitos humanos.

\subsubsection{A EDUCAÇÃO PRISIONAL NO BRASIL}

O diretor-geral do Departamento Penitenciário Nacional (Depen), Airton Michels, admitiu que antes de pensar em ressocializar presos, como prevê a Lei de Execuções Penais, os governos estaduais e federal têm pela frente o desafio de garantir condições mínimas de dignidade em todas as unidades prisionais existentes no país. 
As recentes denúncias de degradação desses locais em estados como o Espírito Santo, a Paraíba, o Rio Grande do Sul e a Bahia evidenciam uma realidade persistente há décadas.

"Isso acontece há 20 anos. Vem CPI [Comissão Parlamentar de Inquérito], indignação geral, mas nada muda. O sistema penitenciário não tem a importância da saúde e da educação, mas o problema é que, hoje, ele [sistema prisional] é uma vergonha para o país, para a nossa sociedade, para a nossa cidadania. O sistema nos envergonha de nos classificarmos como uma sociedade civilizada. Antes de ressocialização, primeiro tem que ter cumprimento digno de pena", afirmou Michels em entrevista exclusiva à Agência Brasil.

Segundo o diretor-geral do Depen, a condição de detenção oferecida pelos estados a parte significativa dos presos pode ser definida como "tortura". "Hoje, estamos torturando nossos presos no Brasil. Se tem um presídio onde o cara tem que ficar 18 horas em pé para conseguir um horário para deitar, isso é tortura. Digo isto com contundência porque o Estado brasileiro tem que resolver isso", disse Michels. "Não podemos conviver com polícias e a sociedade equipadas com alta tecnologia, e nós colocando as pessoas condenadas nesses pardieiros", acrescentou.

Em 2008, o Ministério da Justiça investiu mais de R \$ 350 milhões no sistema prisional, por meio do Depen e do Programa Nacional de Segurança Pública com Cidadania (Pronasci). Entretanto, os investimentos têm sido insuficientes diante do crescimento da população prisional. Em 1997, existiam 148 mil presos no país e hoje há 454 mil. Alguns estados, segundo o diretor do Depen, não fizeram o dever de casa.

"Os estados simplesmente deixaram acumular seus sistemas prisionais e não tomaram providência. O Rio Grande do Sul não gerou vaga no sistema prisional nos últimos seis anos. Em 2002, o déficit prisional no Rio Grande do Sul era de 2 mil vagas e hoje é de 12 mil. Outros estados também foram omissos. Houve um descuido generalizado com o sistema prisional na história brasileira", criticou.

Michels avalia que, a médio prazo, o Pronasci trará resultados importantes para o sistema penitenciário ao atacar as causas sociais que elevam a criminalidade, fortalecendo a presença do Estado em bairros e favelas. "O ideal para a sociedade não são os presídios. Eles são um mal necessário. O fundamental é evitar que sejam cometidos crimes."

No que se refere à construção de unidades, o governo federal aposta sobretudo em auxiliar os estados na construção de presídios específicos para detentos de 18 a 29 anos, faixa etária na qual se concentra a maior parte da massa carcerária. Os investimentos exigidos, entretanto, são altos. O custo médio da construção de uma cadeia de 400 vagas é hoje de $\mathrm{R} \$ 16$ milhões.

"A intenção é que já no início se consiga prender esse cidadão, colocá-lo em penitenciárias onde ele tenha espaço para estudo, para trabalho e onde possa cumprir a pena com dignidade".

A despeito do risco concreto de o país ser denunciado em cortes internacionais pela situação dos presídios, Michels disse que a disposição do governo federal em enfrentar o problema existe "por filosofia e por princípio".

A educação tem por objetivo formar a pessoa humana do recluso, segundo sua própria vocação, para reinserí-lo na comunidade humana, no sentido de sua contribuição na realização do bem comum.

O tratamento reeducativo é uma educação tardia do recluso, que não a obteve na época oportuna. A esse 
direito corresponde a obrigação da assistência educativa, prevista no art. 17 da LEP.

O legislador não adotou o termo "Tratamento Penitenciário", preferindo a denominação "Assistência Penitenciária" que, segundo o art. 10 da LEP, tem por objetivo a reinserção social do preso e prevenção da reincidência. São instrumentos do tratamento penal:

1. Assistência;

2. Educação;

3. Trabalho;

4. Disciplina.

O tratamento reeducativo é o termo técnico usado no Direito Penitenciário, na Criminologia Clínica e na Legislação Positiva da ONU. Segundo a concepção científica, o condenado é a base do tratamento reeducativo e nele observa-se: sua personalidade, através de exames médico-biológico, psicológico, psiquiátrico; e um estudo social do caso, mediante uma visão interdisciplinar e com a aplicação dos métodos da Criminologia Clínica. É ponto de união entre o Direito Penal e a Criminologia.

Com efeito, o tratamento compreende um conjunto de medidas sociológicas, penais, educativas, psicológicas, e métodos científicos que são utilizados numa ação compreendida junto ao delinquente, com o objetivo de tentar modelar a sua personalidade para preparar a sua reincersão social e prevenir a reincidência.

"Não haverá desenvolvimento na personalidade do delinquente sem condições materiais, de saúde ou proteção de seus direitos, bem como instrução escolar e profissional e assistência religiosa."

A Lei nº 7.210/84, (Lei de Execução Penal - LEP), Seção V, trata, no art. 17, da assistência educacional, que compreende a instrução escolar e a formação profissional do preso e do internado.

É de relevo neste ínterim, aduzir os comentários de Mirabete (2002, p. 73) quanto à assistência educacional: "A assistência educacional deve ser uma das prestações básicas mais importantes não só para o homem livre, mas também àquele que está preso, constituindo-se, neste caso, em um elemento do tratamento penitenciário como meio para a reinserção social."

Continua ainda Mirabete (2002) mencionando o artigo 205 da Constituição Federal que elege "educação, direito de todos e dever do Estado e da família, será promovida e incentivada com a colaboração da sociedade, visando o pleno desenvolvimento da pessoa, seu preparo para o exercício da cidadania e sua qualificação para o trabalho". Informa ainda que no art. 208 da CF está previsto e garantido o direito à educação em qualquer que seja a idade ou condição jurídica, conceituando-a como um direito público subjetivo.

Isto quer dizer que não só a instrução, que é um dos elementos da educação, mas também esta é um direito de todos, sem qualquer limitação de idade. Assim, pois, qualquer pessoa, não importa a idade e tampouco sua condição ou status jurídico, tem o direito de receber educação de que, evidentemente, seja dela carente qualitativa ou quantitativamente. Uma vez que a cada direito corresponde um dever, é a própria Constituição que esclarece ser este do Estado, que deverá prover a educação aos presos e internados se não o tiver feito convenientemente no lar e na escola (Mirabete, 2002, p. 73). 
A Seção V da Lei de Execução Penal trata da Assistência Educacional e informa que esta deve abranger a instrução escolar e também a formação profissional, a obrigatoriedade do ensino de primeiro grau e como elas podem ser realizadas.

Assim, os sentenciados presos sem instrução de primeiro grau têm o direito, como qualquer pessoa, de recebê-la do Estado. É mister que, nos estabelecimentos penais, haja escola ou um dos substitutivos da escola (na configuração tradicional) que atualmente existem, [...] pelas escolas públicas ou particulares que ofereçam cursos especializados [...]. (Mirabete, 2002, p. 74).

No Brasil a educação no sistema penitenciário é iniciada a partir da década de 1950. Até o principio do Século XIX, a prisão era utilizada unicamente como um local de contenção de pessoas - uma detenção. Não havia proposta de requalificar os presos. Esta proposta veio a surgir somente quando se desenvolveu dentro das prisões os programas de tratamento. Antes disso, não havia qualquer forma de trabalho, ensino religioso ou laico.

Pensava-se que somente a detenção proporcionaria transformação aos indivíduos enclausurados. A ideia era que estes refizessem suas existências dentro da prisão para depois serem levados de volta à sociedade. Entretanto, percebeu-se o fracasso desse objetivo. Os índices de criminalidade e reincidência dos crimes não diminuíram e os presos em sua maioria não se transformavam. A prisão mostrou-se em sua realidade e em seus efeitos visíveis denunciadas como "grande fracasso da justiça penal". (Foucault, 1987).

Assim, somente nos meados dos anos 50, constatou-se o insucesso deste sistema prisional, o que motivou a busca de novos rumos, ocasionando na inserção da educação escolar nas prisões. Foucault (1987, p. 224) diz: "A educação do detento é, por parte do poder público, ao mesmo tempo uma precaução indispensável no interesse da sociedade e uma obrigação para com o detento."

O modelo dessa forma educativa no Brasil está localizado no Estado de São Paulo. Tavolaro (1999) conta que embora inicialmente não houvesse a participação da sociedade. Conforme revela o histórico da educação de presos no Estado, até 1979, o ensino básico nos presídios era executado por professores comissionados pela Secretaria de Educação, seguindo o Calendário letivo das escolas oficiais, com seriação anual, e fazendo uso do material didático-pedagógico aplicado as crianças. Isso mudou em 1988, quando a responsabilidade pela educação de presos foi delegada a Fundação Estadual de Amparo ao Trabalhador Preso - FUNAP, encarregada da remuneração dos monitores, funcionamento das escolas e metodologia de ensino a ser aplicada.

A Relatoria Nacional para o Direito Humano à Educação apresentou à Comissão de Educação da Câmara dos Deputados parecer preliminar sobre missão realizada entre setembro de 2008 e fevereiro de 2009 que verificou a situação educacional nas prisões brasileiras.

A missão visitou dez unidades nos estados de Pernambuco, São Paulo, Rio Grande do Sul e Pará e colheu mais de 200 depoimentos de presos, educadores, diretores e agentes penitenciários, promotores, juízes, defensores, além de ativistas de organizações de educação e direitos humanos.

O relatório mostra que a oferta de educação no sistema prisional brasileiro ainda é encarada como privilégio, apesar de ser garantida em lei. O pensamento é compartilhado por diretores de unidades, agentes prisionais e pela própria sociedade. 
Durante seis meses, uma equipe visitou dez unidades prisionais em Pernambuco, no Pará, em São Paulo e no Rio Grande do Sul, entrevistando mais de 200 pessoas entre presos, educadores, juízes, promotores e agentes penitenciários.

A relatora Denise Carreira, responsável pelo estudo, aponta que a educação formal nas prisões, quando ofertada, ocorre de forma precária. Segundo ela, só $18 \%$ dos presos têm acesso a algum tipo de atendimento educacional, o que inclui outros cursos, como aulas de violão. As dez unidades visitadas pela comissão ofereciam educação aos presos, mas sempre em condições inadequadas.

Um dos fatores que dificultam a oferta é a superlotação das unidades. Além de condições físicas precárias, o relatório mostra como outra principal deficiência a falta de professores capacitados. $\mathrm{Na}$ maioria dos estados, a educação no sistema prisional não é responsabilidade da Secretaria de Educação, mas da administração penitenciária. Em alguns estados, como São Paulo, são os próprios presos com maior nível de escolaridade que dão aulas aos outros encarcerados.

"Nenhuma unidade da Federação tem uma política de educação nas prisões, um documento norteador com metas de acesso, qualidade, um projeto pedagógico. O que predomina é a improvisação. A educação nas prisões fica em um limbo entre a segurança pública, a administração penitenciária e a educação", alerta. Segundo Denise, a maior parte da população carcerária do país não concluiu o ensino fundamental.

Outro grande problema verificado pela comissão é a falta de creches e berçários nas unidades femininas. Em alguns estados, os filhos das presas podem permanecer com a mãe até completar 3 anos de idade. Mas não há estrutura para receber essas crianças.

Para resolver a precariedade do ensino, a relatora defende que o Brasil precisa, em primeiro lugar, repensar o seu modelo prisional. "Precisamos discutir se o modelo de prisão que a sociedade brasileira necessita é esse, o de confinamento dos seres humanos como principal forma de punição. $\mathrm{O}$ primeiro obstáculo é a educação ser considerada um privilégio, ela é um direito fundamental dessas pessoas e também da sociedade, que está investindo nas unidades prisionais na perspectiva de que essas pessoas possam se reintegrar e contribuir para o desenvolvimento do país", afirma.

Entre as recomendações do relatório que será entregue aos parlamentares está a aprovação com urgência de um projeto de lei que permite a remissão da pena pelo estudo. "Nós temos sete projetos de lei tramitando que abordam a matéria. Hoje, a lei de execução penal garante a remissão de pena por trabalho, em que cada dia trabalhado reduz um dia na pena do preso. No caso do estudo, isso não é garantido, seria um estímulo e um reconhecimento do investimento em educação", acrescenta.

Outra recomendação é que sejam aprovadas com urgência pelo Conselho Nacional de Educação as diretrizes nacionais de educação nos sistemas prisionais. Elas foram elaboradas em 2006 e serviriam como norteadoras para que cada estado pudesse elaborar sua própria política.

\subsubsection{A EDUCAÇÃO PRISIONAL NO ESTADO DO PIAUÍ}

No Estado do Piauí o projeto Educando para a Liberdade já formou 134 detentos das penitenciárias estaduais desde seu lançamento, há três anos. Eles concluíram a segunda etapa do programa Educação de Jovens e Adultos (EJA), e outros aprenderam a ler e a escrever. 
Os presos de todas as penitenciárias públicas estaduais são beneficiados com o programa Educando para a Liberdade. No ano de 2005 As três penitenciárias da Capital do Estado do Piauí, Teresina - a Feminina, a Irmão Guido e a Casa de Albergados - formaram 37 pessoas. A Penitenciária Regional de Bom Jesus formou 16; a de Esperantina, 11; a de Floriano, 16; a de Parnaíba, 18; a de Picos, 14; e a de Oeiras formou 04. Em Altos, a Major César Oliveira formou 18.

O projeto é realizado através de parceria entre a Secretaria da Justiça e de Direitos Humanos e a Secretaria Estadual da Educação e Cultura (Seduc). A Seduc fornece 23 professores e material didático para os detentos, além de material de apoio aos professores. A Secretaria da Justiça e de Direitos Humanos garante o transporte dos professores.

As turmas começam com 30 alunos. Em 2005, foram matriculados 360 alunos em todos os presídios estaduais, dos quais mais de $90 \%$ estão em penitenciárias de regime fechado. A última turma a se formar, no dia 8 de março de 2005, foi a da Major César Oliveira. A maioria dos presos que tiveram formatura agora continuaram estudando.

As aulas do ano letivo 2007 no sistema prisional tiveram início dia 12, com a participação de 560 detentos matriculados, em 13 das 14 unidades penais do Piauí. A única unidade excluída do projeto Educando para a Liberdade é a Casa de Custódia de Teresina, por abrigar somente internos provisórios que aguardam o julgamento dos processos. A rotatividade na Casa de Custódia da Cidade de Teresina é bastante alta, o que prejudicaria a instalação de salas de aula na unidade penal.

São mais de 400 livros didáticos do projeto EJA - Educação de Jovens e Adultos, cadernos brochuras, lápis com borracha, cola, caneta, resmas e demais materiais didáticos. Todo o material é usado pelos detentos orientados pelos 35 professores da Secretaria da Educação à disposição da Secretaria da Justiça para dar continuidade ao projeto Educando para a Liberdade, que já alfabetizou dezenas de detentos nos presídios da capital e do interior do Estado.

A Secretaria da Justiça do Estado do Piauí encaminhou o material didático aos presídios do interior do Estado. Foram enviados livros, cadernos, canetas e demais materiais para as penitenciárias de Esperantina, Floriano, Oeiras, Picos, Bom Jesus, além da penitenciária mista de Parnaíba.

\section{EDUCAÇÃO E TRABALHO}

A Lei de Execução Penal (Lei Federal nº 7.210/84) estabelece que a assistência educacional compreende instrução escolar e formação profissional, mas na prática verifica-se distorção do significado dessas ações. Na prisão, o trabalho, qualquer que seja sua tradução em atividades, é considerado educativo; a educação escolar, por sua vez, não é considerada trabalho intelectual.

A oposição entre educação e trabalho é reforçada pela existência de mecanismos de incentivo ao trabalho, como a remição da pena, enquanto freqüentar a escola constitui-se num desafio contra o cansaço, a falta de recursos pedagógicos e outros obstáculos já apontados.

\subsection{NECESSIDADE DE ESTÍMULO}

O baixo índice de freqüência da população encarcerada às escolas na prisão deve-se à falta de estímulo e 
condições, e não à falta de interesse dos educandos.

Nesse sentido, a remição da pena pelo estudo, reivindicada por organizações da sociedade civil, poderia ser um importante fator de motivação. Sobre o tema tramita no Congresso Nacional o PL 6254/05, do deputado João Campos (PSDB-GO) e o PL 4230/04, do deputado Pompeo de Mattos, PDT/RS. Também há previsão para que, em meados de julho, o Ministério da Justiça apresente projeto de lei alterando a Lei de Execução Penal, para garantir a remição de um dia de pena por dezoito horas de estudo; e a concessão de mais $50 \%$ sobre o tempo acumulado a remir, no caso da conclusão do ensino fundamental, médio ou superior durante o cumprimento da pena, desde que certificada pelo órgão competente do sistema de educação.

A remição pelo estudo, no entanto, deve vir acompanhada de outras medidas que possibilitem e valorizem as atividades educativas no interior dos presídios. É preciso sensibilizar funcionários e também população carcerária para a importância do funcionamento de escolas no interior dos presídios, tema bastante polêmico diante da situação de tensão e violações de direitos - sofridas e praticadas - pelos dois grupos. A valorização da educação no sistema prisional também está vinculada ao caráter e à forma que assumirá. Este debate foi iniciado com os seminários promovidos pelo MEC/SECAD no último ano, mas ainda não foi estendido à sociedade. A discussão pública sobre o sistema penitenciário é restrita aos aspectos da segurança e violência.

Os processos educativos são sempre relacionados à perspectiva da ressocialização, reinserção e outros termos que remetem para a reorganização da vida quando e se conquistada a liberdade. Sem dúvida esta é uma perspectiva fundamental, mas não se pode deixar de considerar que os processos educativos, em qualquer situação, exercem influência sobre a vida presente dos envolvidos.

\subsubsection{AS DIFICULDADES DO EXERCÍCIO DO DIREITO À EDUCAÇÃO}

A educação penitenciária que não constitui uma modalidade formal de ensino e que, assim, estaria inserida na educação de jovens e adultos carece de orientação e articulação com as ações do Ministério da Educação (MEC). Isso fica evidente ao perceber que a primeira tentativa de ação conjunta com o Ministério da Justiça (MJ) e a Secretaria Nacional de Direitos Humanos (SNDH) data de março de 2005, apesar do Plano Nacional de Educação, aprovado em 2001, estabelecer que todas as unidades e os estabelecimentos que atendem adolescentes e jovens infratores devem oferecer "programas de educação de jovens e adultos de nível fundamental e médio, assim como formação profissional". O objetivo desta ação seria desenvolver um projeto educativo específico a partir de um mapeamento da situação prisional do país e identificação de ações educativas voltadas para os presos em diferentes estados.

Além desta notável ausência do MEC, as ações voltadas a essa população implantadas em cada estado variam bastante. O estudo "Assistência educacional nos estabelecimentos penais" realizado em 2004 por Paulo Sena, da consultoria legislativa da Câmara dos Deputados, traz um resumo da situação da educação nos estabelecimentos penais por estado em 1997. Apenas Tocantins e Espírito Santo afirmaram não oferecer ensino fundamental nas prisões. Há ensino médio nas prisões do Rio Grande do Sul, Paraná, Minas Gerais, Distrito Federal, Bahia, Ceará, Sergipe, Pernambuco, Rio Grande do Norte, Rondônia, Roraima e Acre; em São Paulo e Goiás este nível é realizado por meio dos exames de certificação. A participação do setor privado varia também em todos os estados, mas na maior parte deles há convênios com as entidades do Sistema $\mathrm{S}$ e a Fundação Roberto Marinho. Até mesmo a responsabilidade administrativa é assumida por diferentes órgãos administrativos. Em Goiás, Amazonas e Paraná está a 
cargo das secretarias estaduais de educação e, nos demais estados, é atribuição das secretarias responsáveis pela administração do sistema penitenciário. O levantamento não detalha a abrangência das atividades educacionais em cada sistema prisional ou no interior de cada penitenciária.

\subsection{ESCOLA VIRTUAL}

Na Câmara Federal, tramita uma única proposta voltada à educação da população encarcerada, apresentada pelo deputado federal Carlos Nader (PL-RJ). O projeto de lei 5189/05 determina a implantação de escolas virtuais nos presídios federais e estaduais. De acordo com o texto, os presos e agentes penitenciários interessados receberão cursos de alfabetização, ensino fundamental, médio e técnico-profissionalizante. As aulas poderão ser ministradas por instituições públicas ou entidades filantrópicas credenciadas pelo Ministério da Educação. O parlamentar justifica que o sistema de escola virtual permitiria ao aluno assistir as aulas à distância, sem riscos para a segurança pública.

Sistema Penitenciário Brasileiro não consegue atingir o seu principal objetivo que é a ressocialização dos seus internos. A superlotação das prisões, as precárias e insalubres instalações físicas, a falta de treinamento dos funcionários responsáveis pela reeducação da população carcerária e própria condição social dos que ali habitam, são sem sombra de dúvidas, alguns dos principais fatores que contribuem para o fracasso do sistema penitenciário brasileiro no tocante a recuperação social dos seus internos.

O Estado quando condena um indivíduo que cometeu um crime contra a sociedade e por conseqüência aplica a esse uma pena restritiva da liberdade, teoricamente, acredita que após o cumprimento da sentença expedida esse indivíduo estará pronto para voltar, em harmonia, ao convívio social. O que então se costuma chamar de reeducação social, uma espécie de preparação temporária pela qual precisa passar todo criminoso condenado pela justiça.

No entanto, essa "reeducação" que objetiva o Estado na prática não existe. Primeiro porque o que tem sido a principal preocupação do sistema penitenciário ao receber um indivíduo condenado não é sua reeducação, mas sim com a privação de sua liberdade. Isso é fácil de ser constatado na medida em que analisamos as estruturas da maioria das penitenciárias brasileiras, formadas por excesso de grades, muros enormes e um forte efetivo policial, tudo isso com um único objetivo, evitar a fuga.

Enquanto isso a reincidência criminal cresce a cada dia, e na maioria das vezes constata-se que o indivíduo que deixa o cárcere após o cumprimento de sua pena, volta a cometer crimes piores do que anterior, como se a prisão o tivesse tornado ainda mais nocivo ao convívio social.

Partindo dessas considerações é possível constatar que a privação da liberdade única exclusivamente não favorece a ressocialização. Desta forma é preciso que seja feito algo no sentido, senão, de resolver, ao menos, de minimizar ao máximo esse equívoco. Para isso se faz necessário o desenvolvimento de programas educacionais dentro do sistema penitenciário voltados para Educação básica de Jovens e Adultos que visem alfabetizar e, sobretudo, trabalhar para a construção da cidadania do apenado. Conforme o sociólogo Fernando Salla (in: Educação, 1999, p. 67) “[...] por mais que a prisão seja incapaz de ressocializar, um grande número de detentos deixa o sistema penitenciário e abandona a marginalidade porque teve a oportunidade de estudar."

Dessa forma outro aspecto relevante a ser aqui considerado é o perfil da população penitenciária no Brasil, que segundo os dados fornecidos pelo Departamento Penitenciário Nacional do Ministério da 
Justiça, a maior parte da massa carcerária deste país é composta por jovens com menos de trinta anos e de baixa escolaridade ( $97 \%$ são analfabetos ou semi-analfabetos). O restante, quase que na totalidade, são pessoas que não tiveram condições de concluir os estudos por razões variadas inclusive por terem sido iniciadas no crime ainda cedo.

Diante desse quadro podemos afirmar que a criminalidade estar intimamente ligada à baixa escolaridade e ambas a questão econômica e social. De modo que precisam ser desenvolvidos dentro das prisões projetos educacionais que trabalhe para a conscientização dos educandos, fazendo-os o perceber a realidade e conseqüentemente seu lugar na história. Pois um indivíduo que nasceu na miséria e por conseqüência não teve acesso a uma educação satisfatória ou a de nenhum tipo, não pode agir com discernimento em seus atos.

Uma educação dentro do sistema penitenciário deve trabalhar com conceitos fundamentais, como família, amor, dignidade, liberdade, vida, morte, cidadania, governo, eleição, miséria, comunidade, dentre outros. Nesse aspecto, Gadotti (in: Educação, 1999, p. 62) salienta a necessidade de trabalhar no reeducando "[...] o ato anti-social e as conseqüências desse ato, os transtornos legais, as perdas pessoais e o estigma social. "Em outras palavras, desenvolver nos educandos a capacidade de reflexão, fazendo-os compreender a realidade para que de posse dessa compreensão possam então desejar sua transformação. Assim como saliente o artigo... "[...] uma educação voltada para a autonomia intelectual dos alunos, oferecendo condições de análises e compreensão da realidade prisional, humana e social em que vivem".

O sistema penitenciário necessita de uma educação que se preocupe prioritariamente em desenvolver a capacidade crítica e criadora do educando, capaz de alertá-lo para as possibilidades de escolhas e a importância dessas escolhas para a sua vida e conseqüentemente a do seu grupo social. Isso só é possível através de uma ação conscientizadora capaz de instrumentalizar o educando para que ele firme um compromisso de mudança com sua história no mundo. Sobre isso, Gadotti (in: Educação, 1999, p. 62) diz que "Educar é libertar [...] dentro da prisão, a palavra e o diálogo continuam sendo a principal chave. A única força que move um preso é a liberdade; ela é a grande força de pensar."

Em sua análise Paulo Freire (1980, p. 26) afirma que:

A conscientização é [...] um teste de realidade. Quanto mais conscientização, mais "dês-vela" a realidade, mais se penetra na essência fenomênica do objeto, frente ao qual nos encontramos para analisá-lo. Por esta mesma razão, a conscientização não consiste em "estar frente à realidade" assumindo uma posição falsamente intelectual. A conscientização não pode existir fora da "práxis", ou melhor, sem o ato açãoreflexão. Esta unidade dialética constituiu, de maneira permanente, o modo de ser ou de transformar o mundo que caracteriza os homens.

A conscientização trabalha a favor da desmistificação de uma realidade e é a partir dela que uma educação dentro do sistema penitenciário vai dar o passo mais importante para uma verdadeira ressocialização de seus educandos, na medida em que conseguir superar a falsa premissa de que, "uma vez bandido, sempre bandido".

No sistema carcerário há uma grande dificuldade no que diz respeito à educação, pois existe carência de recursos materiais e não há, de forma precisa, o incentivo do governo e da sociedade para que o cidadão preso adquira conhecimentos úteis à vida dele, conhecimentos que, por sua vez, são muito importantes porque neste momento esses cidadãos não estarão ociosos e terão uma oportunidade, que muitas vezes, 
nunca tiveram: a de aprender.

Fatores como esses não só compromete a ressocialização do detento após o cumprimento da pena como têm reflexos diretos na questão da reincidência ao crime. Para reverter esse cenário dramático, os ministérios da Justiça, da Educação e a Unesco se uniram para estabelecer no País uma política nacional de ensino nos presídios. O objetivo é ampliar o acesso e melhorar a qualidade dos programas desenvolvidos pelos estados.

São muitas as razões para o baixo índice de oferta de ensino no sistema penitenciário. Historicamente, de acordo com o Departamento Penitenciário Nacional (Depen), do Ministério da Justiça, a educação nas prisões vem sendo realizada pelos estados de forma pouco sistematizada, muitas vezes baseada no voluntarismo ou dependente de iniciativas da direção de cada unidade prisional. Isso se deve a pouca aproximação entre as secretarias estaduais de educação e de administração penitenciária, de forma a coordenar programas voltados especificamente para a educação do preso.

A realidade carcerária também não é levada em conta no aspecto da formação adequada dos profissionais da área de educação, que muitas vezes não tem qualquer preparo para lidar com o preso. "Os profissionais da área de ensino que vão lidar com presos precisam de qualificação específica, pois o trabalho é diferente do realizado na sala de aula comum", explica o diretor do Depen, Maurício Kuehne.

Além de a oferta de ensino nos presídios ser restrita, há ainda uma grande evasão escolar dentro do sistema. Os presos reclamam da falta de infra-estrutura, material escolar de qualidade, merenda, uniforme. Segundo eles, conteúdos programáticos não consideram a realidade carcerária, nem a formação da cidadania.

A educação não é reconhecida como direito fundamental e há ainda a incompatibilidade do horário da escola e do trabalho, dificultando a participação dos detentos que trabalham. Falta compromisso por parte de alguns professores com a escola do presídio e utilização de metodologia atraente. Uma das principais queixas diz respeito ao fato de o estudo não contribuir para a remissão da pena, como ocorre com o trabalho. Já para os educadores, a principal queixa é quanto à falta do espaço físico para o ensino nos presídios mais antigos. Atualmente, o DEPEN só aprova planos para a construção de presídios se a planta destinar espaço para a instalação de salas de aula.

As propostas apresentadas darão corpo às diretrizes para uma Política Nacional de Educação nas Prisões. A meta é ajudar os estados a melhorar a qualidade do ensino no sistema prisional e aumentar o número de presos que têm acesso à educação no País. Para combater a evasão escolar, o governo federal está para concluir o texto de um projeto de lei que reduz um dia de pena por cada 18 horas de efetiva presença em atividades do ensino.

Os ministérios da Justiça e da Educação financiam, desde 2004, projetos-pilotos de alfabetização e educação em estabelecimentos penais do Rio Grande do Sul, Paraíba, Tocantins, Goiás, Rio de Janeiro e Ceará, por meio do projeto Educando para a Liberdade. O programa coloca em prática ações voltadas para a educação de presos, formação de educadores e revisão de aspectos pedagógicos. Até agosto Acre, Pará, Pernambuco, Espírito Santo, Maranhão e Mato Grosso do Sul também adotarão o programa, que deve ser estendido a todos os estados. 
As diretrizes para a criação da Política Nacional de Educação Nas Prisões estão em fase final de elaboração pelas equipes técnicas dos ministérios da Justiça e da Educação. As propostas serão apresentadas aos ministros Márcio Thomaz Bastos e Fernando Haddad e, em seguida, encaminhadas ao Conselho Nacional de Política Criminal e Penitenciária e ao Conselho Nacional de Educação.

As proposições foram elaboradas com base nas discussões promovidas pelos seminários regionais e nacionais para ensino nos presídios e têm como base três eixos temáticos: gestão e articulação, formação de profissionais (educadores, agentes penitenciários e gestores) e aspectos pedagógicos.

As diretrizes contemplam a garantia da inclusão dos alunos presos no censo escolar. Dessa forma, os estabelecimentos penais envolvidos passam a receber recursos financeiros do Ministério da Educação. O documento também prevê a elaboração de um currículo próprio para educação nas prisões, além da realização de um diagnóstico da vida escolar do preso no momento em que ele entra no sistema.

Outro ponto em destaque é a garantia de certificação nos cursos regulares de ensino fundamental e médio e projetos extraclasses. $\mathrm{O}$ documento defende ainda a adoção de políticas de incentivo à leitura nas unidades prisionais, com a implementação de bibliotecas e programas que atendam não somente aos alunos matriculados, mas todos os presos e integrantes da comunidade do sistema prisional.

Os sistemas de educação para adultos surgiram e se desenvolveram na América Latina sob o signo de modernização da reforma da democratização tanto pedagógicas como sociais, e com isto, o aparecimento de teses antitradicionalistas fragmentadas em múltiplas tendências internas. Tanto no discurso quanto na prática da educação para adultos era possível identificar que embora heterogêneas, se uniram para contestar severamente a ordem tradicional. Tais oposições modernizantes incluíam de acordo com as peculiaridades sócio políticas e os momentos históricos dos diversos países, as tendências reformistas no plano social, perspectivas democráticas vinculadas à instituição programada e a distância, bem como, a promoção do estudante livre, propostas populistas e outras modalidades de enfoque militantes.

A trajetória histórica da Educação de adultos no Brasil é um desafio extremamente complexo, pois essa oferta compreende uma pluralidade de experiências, podendo se observar um caráter de reposição e suplência, em busca do tempo perdido, abrangendo os processos de escolarização, profissionalização e de organização popular. Os primeiros trabalhos desenvolvidos no Brasil voltado a ações de educação para adultos ocorreram em 1549 com a vinda dos jesuítas que se dedicaram a duas tarefas principais: a pregação da fé católica e o trabalho educativo que primeiramente os ofícios eram ensinados aos indígenas e mais tarde, aos escravos. Piletti (1988, p.166), nos apresenta com clareza o trabalho jesuítico dizendo que: "Os jesuítas [...] com seu trabalho educativo, ao mesmo tempo em que ensinavam as primeiras letras e a gramática latina, ensinavam a doutrina e os costumes europeus".

A partir de 1930 a educação de adultos foi incluída no rol das reivindicações educacionais, com a transformação da estrutura econômica urbano - agrícola - comercial em um modelo industrial emergente, exigido como qualificação de mão - de- obra, principalmente no que se refere à decifrar o código escrito de mensagens nos manuais de funcionamento do maquinário, ordens e outros textos de utilidade para a indústria e até mesmo como mudança radical na vida da população.

A constituição de 1934 estabeleceu novas atribuições educacionais sendo traçada nas diretrizes da Educação Nacional pontos importantes destacando-se dentre eles 'a educação como direito de todos e a 
assistência aos estudantes necessitados'. Tais considerações que, de um lado iniciaram um Sistema Nacional de Educação, do outro assinalou uma profunda centralização de poder e controle.

Em 1947, inicia-se no âmbito do Ministério da Educação a campanha de Educação de Adultos em função da necessidade de aumentar as bases eleitorais para sustentação do governo central que previa a alfabetização em três meses e a condensação do curso primário em sete meses.

Num curto espaço de tempo, foram criadas várias Escolas Supletivas com cursos noturnos para alunos trabalhadores. Nesse momento, o analfabetismo era concebido como causa e não efeito da situação econômica, social e cultural do país. Foram realizadas ações concretas no sentido de possibilitar a escolarização dos excluídos e as idéias de alfabetização de adultos com um sentido de conscientização e leitura de mundo proposta por Paulo Freire, ganharam consistência e força.

Entre o período de 1961 a 1965 multiplicam-se os programas de alfabetização e educação popular, orientados pelas idéias de Paulo Freire e a partir de então, surgem organizações de luta pelos problemas sociais e educacionais como: O Movimento de Educação de Base (MEB) patrocinado pelo Governo Federal que foi articulado pela Conferência Nacional dos Bispos do Brasil (CNBB) e disponibilizado na modalidade de Educação a Distância através da 'Educação radiofônica' nas regiões do nordeste pelas dioceses de Natal e Aracaju; os Centros Populares de Cultura da União dos estudantes; a Campanha Pé no Chão Também se Aprende a Ler, da Secretaria de Educação de Natal; e outras iniciativas de caráter regional ou local. O Movimento de Educação de Base (MEB) foi estruturado para efetivar-se nos anos de 1961 a 1965 e ser instalado no seu primeiro ano 15000 escolas radiofônicas para atender a demanda de mercado, porém, somente em julho de 1963 sua estruturação foi iniciada, mas, instituída oficialmente em janeiro de 1964, estabelecida de acordo com o Artigo 4º do Decreto no .53465 de 21 de janeiro de 1964 relatando que: O programa convocaria e utilizaria a cooperação e os serviços de agremiações estudantis e profissionais, associações esportivas, sociedade de bairro e municipalistas, entidades religiosas, organizações civis e militares, associações patronais, empresas privadas, órgãos de difusão, o magistério e todos os setores mobiliáveis.

Atendendo o Decreto instituído, determinou-se que a alfabetização de adultos dar-se-ia sob a aplicabilidade do método Paulo Freire e Fiori (Freire 1987, p.xxi) com propriedade, em seus escritos, descreve a abrangência do caráter social que o método traz em sua essência: [...] um método de cultura popular: conscientiza e politiza. Não absorve o político no pedagógico, mas também não põe inimizade entre educação e política. Distingue-as, sim, mas na unidade do mesmo movimento em que o homem se historiciza e busca se reencontrar-se, isto é, busca ser livre. Não tem a ingenuidade de supor que a educação, só ela, decidirá dos rumos da história, mas tem, contudo, coragem suficiente para afirmar que a educação verdadeira conscientiza as contradições do mundo humano, sejam estruturais, superestruturais ou interestruturais, contradições que impelem o homem a ir adiante[...]. Um método pedagógico de conscientização alcança as últimas fronteiras do humano. E como o homem sempre se excede, o método também o acompanha. É 'a educação como prática da liberdade'. Sem dúvidas, a tomada de consciência, a busca de liberdade proposta por Paulo Freire, aproximaria os envolvidos - excluídos a descoberta do conhecimento como base sustentadora para as 'relações homem-mundo, para a conscientização, a criação, interpretação dos problemas existentes, a reflexão, superação de conflitos através de idéias não como consumo, mas produzi-las e transformá-las em ação por meio da comunicação.

Concomitante a essas práticas Paulo Freire (1987, p.ci) focaliza que: 
Sendo os homens seres em "situação", se encontram enraizados em condições tempo-espaciais que os marcam e a que eles igualmente marcam. Sua tendência é refletir sobre sua própria situacionalidade, na medida em que, desafiados põe ela, agem sobre ela. Esta reflexão implica, por isto mesmo, algo mais que estar em situacionalidade, que é a sua posição fundamental. Os homens são porque estão em situação. E serão tanto mais quanto não só pensem criticamente sobre sua forma de estar, mas criticamente atuem sobre a situação em que estão.

Todos estes programas de alfabetização/escolarização são extintos e seus organizadores são presos ou exilados devido o Golpe Militar de 1964, em que o governo/militares de forma autoritária instalam no país reformas reacionárias a todos os níveis de ensino, impondo de forma vertical as diretrizes educacionais, sem a participação dos maiores interessados - alunos, professores e outros segmentos sociais, freando os avanços e as conquistas populares.

Neste período o governo lança o MOBRAL (Movimento Brasileiro de Alfabetização), tendo caráter assistencialista e conservador, com o objetivo centrado apenas na alfabetização de adultos, mediante um intenso controle Federal.

A partir de 1971 soma-se ao MOBRAL o Ensino Supletivo com a tarefa de escolarização correspondente ao Ensino Primário, permanecendo em vigor até a década de 80. Com a implantação da Lei de Diretrizes e Bases da Educação Nacional em 1971 (LDB nº. 5692/71), acrescenta-se à Educação de Adultos a idéia de 'aceleração escolar', incorporando o caráter tecnicista. Mediante isso Paiva (1997, p. xcv) nos diz que:

[...] alentada pelos "sucessos" do milagre econômico que florescia, à causa dos direitos humanos, da exclusão [...] havia que se fazer, do jovem e do adulto não escolarizados, trabalhadores qualificados, pelo uso da leitura, da escrita e do cálculo, conformando o novo conceito de alfabetização. Havia que fazê-los produtivos, capazes de valorizar suas potencialidades pela educação, tornarem-se um capital necessário e engajado no sistema capitalista. Para os que conseguiam vencer as barreiras de serem trabalhadores e estudantes em seu tempo não apropriado pelo capital, o modelo acenava com a "ascensão social" e atribuía, aos que não conseguiam, a culpa pelo próprio fracasso.

Em 1985, o MOBRAL foi substituído pela Fundação Educar com apoio técnico e financeiro de entidades civis e de Prefeituras Municipais para fomentar apoio aos que não tiveram acesso a escola, ou seja, os excluídos.

A partir de 1986, devido a crise econômica estes grupos ampliaram seus projetos/ou iniciaram novos projetos firmando convênios com a mesma fundação.

\section{O SISTEMA PRISIONAL DO ESTADO DO PIAUÍ}

A Secretaria da Justiça do Estado do Piauí foi criada pela Lei nº. 3.869, de 13 de maio de 1983.

O artigo 75 da citada Lei destinou-se a criação da Secretaria da Justiça, órgão integrante da Administração Direta do Estado, com a finalidade de executar a política do governo relacionada com a ordem Jurídica, preservação do regime, o estudo dos assuntos concernentes à cidadania, garantias constitucionais, tratamento de presos, assistência jurídica e livre exercício dos poderes constituídos, com 
jurisdição em todo território do Estado.

Competindo-lhe coordenar os assuntos relacionados com o funcionamento das instituições, com a ordem jurídica e a assistência judiciária do Estado; administrar o sistema penitenciário do Estado e promover a implantação de métodos e técnicas modernas nos serviços prisionais; velar pela proteção dos direitos humanos, em colaboração com os órgãos federais competentes e em coordenação com a Secretaria de Segurança do Estado; organizar e manter o cadastro de provimento e vacância dos ofícios e serventias da Justiça; preparar os atos necessários ao provimento dos cargos da Magistratura, do Ministério Público e serventuários da Justiça; exercer outras atribuições correlatas e que se enquadrem no âmbito de suas atribuições.

Naquele período a Defensoria Pública estava ligada a Secretaria de Justiça que era dirigida por um coordenador indicado pelo Secretário de Justiça, e nomeado em, comissão pelo Governador do Estado e como órgão colegiado, apenas o Conselho Penitenciário fazia parte da estrutura básica da Secretaria.

Ainda, pela Lei-Delegada $n^{\circ} .158$, de 16 de junho de 1982, as atribuições conferidas à Procuradoria Geral da Justiça passaram para competência da Secretaria de Justiça, onde dispõe sobre a organização da Assistência Judiciária do Estado.

Em 08 de agosto de 1983, pelo Decreto n 5.504, foi aprovado o Regulamento da Secretaria de Justiça.

Nova reforma administrativa entra em vigor com a Lei $\mathrm{n}^{\circ} 4.382$, de 27 de março de 1991 e, a Secretaria de Justiça recebe nova denominação: "Secretaria da Justiça e da Cidadania" - com finalidade de executar a política do Governo relacionada com a ordem jurídica, os assuntos concernentes à cidadania, garantias constitucionais, o sistema penitenciário do Estado, as técnicas modernas dos serviços prisionais e a proteção dos direitos humanos. Com nova estrutura, incluindo mais dois órgãos colegiados: o Conselho Estadual de Entorpecentes e o Conselho de Defesa dos Direitos da Mulher.

No ano de 2003, o Governador do Estado, Wellington Dias encaminhou para a Assembléia Legislativa, mensagem com Indicativo de Projeto de Lei Complementar, propondo a Reforma Administrativa do Estado, obtendo aprovação em quase sua totalidade, implementando assim, a Lei Complementar $\mathrm{n}^{\circ}$. 028, de 09 de junho de 2003, que dispõe sobre a Lei Orgânica da Administração Pública do Estado do Piauí e dá outras providências.

A Secretaria da Justiça foi transformada em Secretaria da Justiça e de Direitos Humanos, com a finalidade de promover, manter, executar e acompanhar a política de Governo relacionada com a cidadania, o sistema penitenciário, os serviços prisionais e a proteção dos direitos humanos, competindo-lhe administrar o sistema penitenciário do Estado, desenvolvendo programas de ressocialização dos presos, com a participação da sociedade; promover a modernização do sistema penitenciário com implantação de políticas disciplinares, com vistas à segurança e à ordem dos presídios; elaborar e executar serviços, programas e projetos de proteção especial às vítimas e testemunhas de crimes; executar política do Governo relacionada à cidadania e aos direitos humanos; zelar pela proteção dos direitos humanos, colaborando com órgãos públicos e entidades não governamentais que se dediquem a igual objetivo ou que tenham por escopo a defesa e o desenvolvimento da cidadania. A nova reforma melhorou a estrutura básica da Secretaria, incluiu mais dois órgãos colegiados: o Conselho Estadual de Direitos Humanos e o Conselho da Comunidade, além de adequar toda administração prisional às determinações da Lei de 
Execução Penal, colocando, assim, a Secretaria dentro das atuais normas legais.

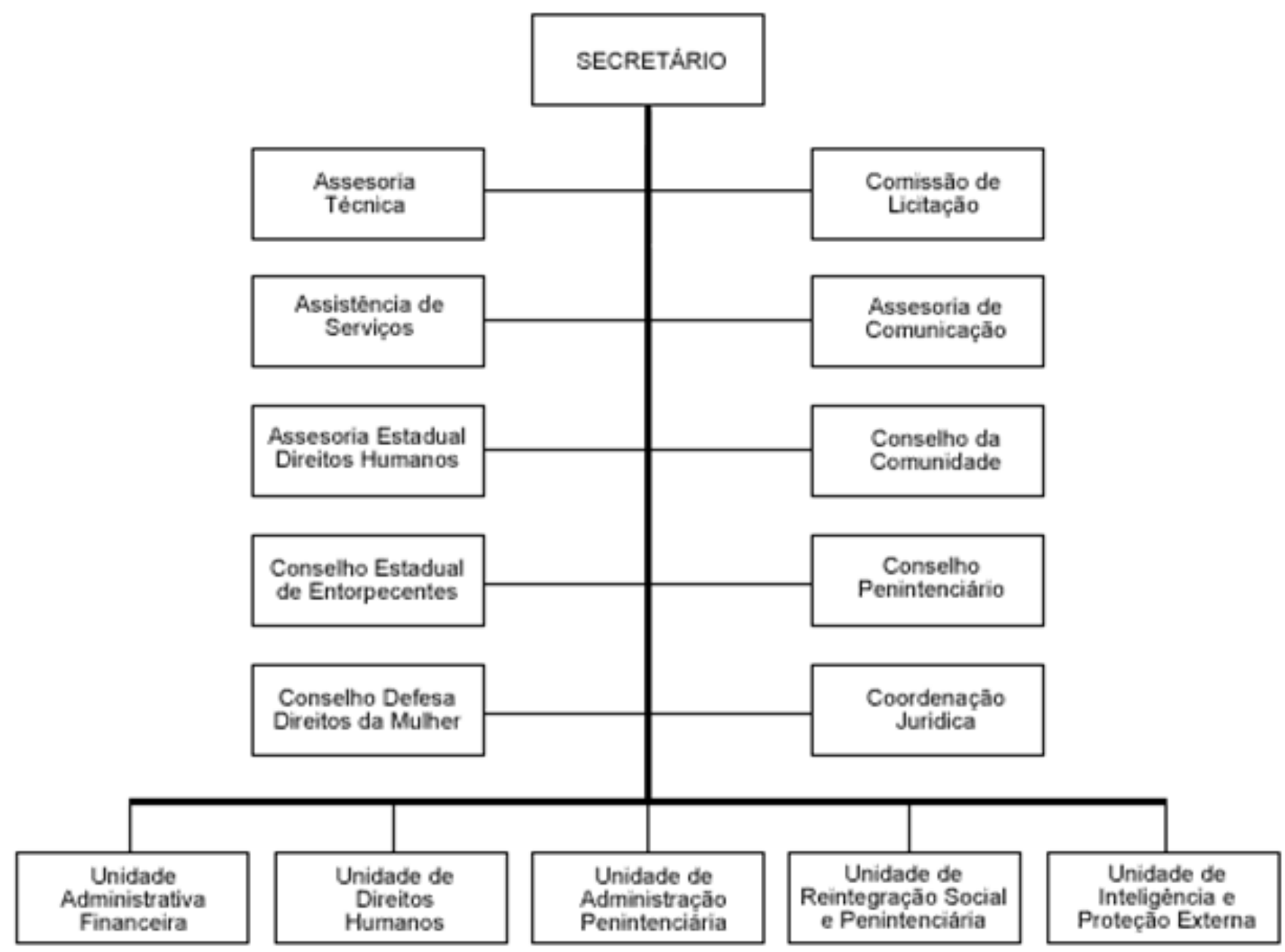

Figura 1 - Atual organograma da Secretaria da Justiça e de Direitos Humanos do Estado do Piauí

O Estado do Piauí conta com 14 (quatorze) Unidades Prisionais espalhadas por diferentes regiões do Estado, a sua população carcerária é de cerca de 2.310 (dois mil, trezentos e dez) detentos dados obtidos junto a Secretaria da Justiça e de Direitos Humanos do Estado do Piauí, Diretoria de Administração Penitenciária.

Organograma da Unidade de Reintegração Social e Penitenciária da Secretaria da Justiça e de Direitos Humanos do Estado do Piauí onde se encontra a Coordenação de ensino dos presídios do Estado do Piauí: 


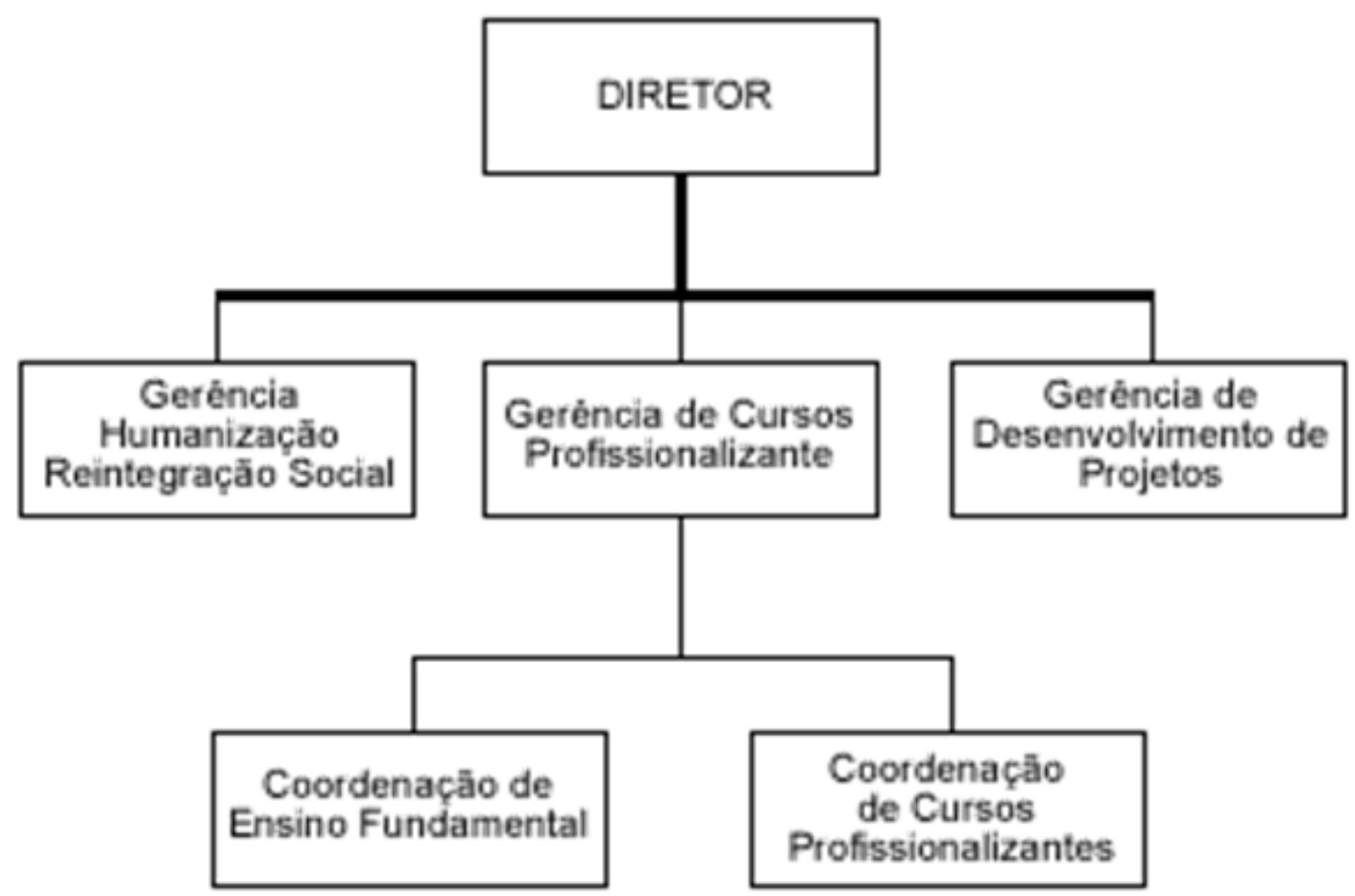

Figura 2 - Organograma da Unidade de Reintegração Social e Penitenciária da Secretaria da Justiça e de Direitos Humanos do Estado do Piauí.

\subsection{A UNIDADE PRISIONAL DE BOM JESUS}

O Piauí situa-se na Região Nordeste do Brasil com uma população estimada de 3.006.885 de habitantes, de acordo com o Censo Demográfico de 2007, realizado pelo IBGE. A Densidade Demográfica é de 11,31 habitantes por $\mathbf{k m}^{2}$, com área de $252.378 \mathbf{~ k m}^{2}$, representando $16,17 \%$ da Região Nordeste e $\mathbf{2 , 9 5 \%}$ de todo o território brasileiro. O Índice de Desenvolvimento Humano (IDH) é de $\mathbf{0 , 6 5 6}$ segundo o Atlas de Desenvolvimento Humano/PNUD (2000).

Bom Jesus é um município brasileiro do Estado do Piauí, sua população estimada em 2007 é de 19.575 habitantes segundo o recente censo do IBGE. A cidade de Bom Jesus tem passado por um período de rápido crescimento populacional e econômico em função da expansão na área agrícola e educacional, sendo a única cidade do Brasil com menos de 20.000 habitantes a dispor de um Campus da Universidade Federal do Piauí e de um Campus da Universidade Estadual do Piauí. Na década de 1990, produtores de soja do Rio Grande do Sul começaram a chegar e a cultivar soja no cerrado do Piauí, principalmente em Bom Jesus e Uruçuí. Hoje, aproximadamente 220 mil hectares são cultivados com soja, arroz e algodão nessa região, considerada a última fronteira agrícola do Brasil. Localizada na região do Vale do Rio Gurguéia, a cidade é muito rica em água subterrânea. Os poços jorrantes (a água sai sem precisar de bombeamento) são abundantes.

A Unidade Prisional de Bom Jesus teve o início de seu funcionamento nos primeiros dias do mês de 
fevereiro do ano de 2004, sendo que no dia 21 de fevereiro do mesmo ano foram removidos 42 (quarenta e dois) detentos da Penitenciária Gonçalo de Castro Lima que fica localizada no Município de Floriano para a nova Unidade Prisional de Bom Jesus.

A Penitenciária Regional de Bom Jesus dispõe apenas de vagas para o sexo masculino, com capacidade para acolher 76 (setenta e seis detentos), possui dois pavilhões, módulo de ensino (escola), módulo de visita íntima, módulo ecumênico, módulo de guarda externa e prédio amplo onde funciona a administração da Unidade Prisional.

O ensino na Unidade Prisional de Bom Jesus foi implantado em 18 de setembro de 2004 com o Projeto "Educando para a Liberdade" contemplando inicialmente 20 (vinte) detentos, sendo que no dia 28 (vinte e oito) de setembro do mesmo ano foi procedido diagnóstico para o desmembramento da turma adotandose o critério de separação entre alfabetização e segundo ciclo $3^{\mathrm{a}}$ e $4^{\mathrm{a}}$ séries de educação de jovens e adultos, atividades educativas que tinham a frente à pedagoga Ivone Antônia da Silva e Marilene de Matos Rosal licenciada em letras/português.

No ano de 2005 o Projeto "Educando para a Liberdade" aumentou o número de alunos da escola para 30 (trinta) reeducandos, sendo uma turma de primeira etapa $\left(1^{\mathrm{a}}\right.$ e $2^{\mathrm{a}}$ séries) e outra turma de segunda etapa ( $5^{\mathrm{a}}$ e $6^{\mathrm{a}}$ séries) de educação de jovens e adultos e uma turma de alfabetização (Alfabetização Solidária) a cargo da professora Maria Fátima Lopes de Oliveira. O Gerente da $14^{\text {a }}$ Gerência Regional de Educação da cidade de Bom Jesus professor de matemática José Antônio Alves Piauilino passou a ser professor voluntário e ministrava a disciplina de matemática uma vez por semana dentro do citado projeto.

A Escola da Penitenciária Regional Dom Abel Alonso Núñez de Bom Jesus, atualmente conta com 25 (vinte e cinco) detentos, os reeducandos freqüentam o Programa de Educação de Jovens e Adultos - EJA que funciona em três etapas: Primeira Etapa ( $1^{\mathrm{a}}$ e $2^{\mathrm{a}}$ Séries), Segunda Etapa ( $3^{\mathrm{a}}$ e $4^{\mathrm{a}}$ Séries) e Terceira Etapa ( $5^{\text {a }}$ e $6^{\text {a }}$ Séries $)$.

As disciplinas ministradas todas são da Educação de Jovens e Adultos - EJA: Matemática, Geografia, História, Inglês, Português, Relações Humanas, Ensino Religioso, Artes (artesanato), sendo que as disciplinas de História e Geografia estão voltadas para a realidade local.

A disciplina Relações Humanas trabalha a parte social, a vida após a saída da Penitenciária, regras de comportamento e de convivência social.

A disciplina de português procura através do estimulo a leitura de livros, revistas e jornais despertar e incentivar o gosto pela leitura.

Os horários das aulas da Escola da Penitenciária ocorrem no turno da manhã entre as 08h00min e às 11h30min de segunda a sexta-feira.

Constatou-se pelos dados do Relatório do Sistema de Informações Penitenciário da Unidade de Prisional de Bom Jesus - INFOPEN (outubro de 2007) e pelos questionários aplicados com os detentos (reeducandos), professores, gerente que a educação é um instrumento necessário e importante para a recuperação dos detentos, conforme veremos nos dados apresentados nos gráficos abaixo. 


\subsection{MARCO CONCEITUAL}

\begin{tabular}{|c|c|c|}
\hline Variável Independente & Variável Interveniente & Variável Dependente \\
\hline Educação & Idade & Recuperação de detentos \\
\hline & Tempo & \\
\hline & Grau de Escolaridade & \\
\hline & Classe Social & \\
\hline
\end{tabular}

\subsection{MARCO OPERACIONAL}

Ressocializar é levar o presidiário a uma adaptação social, ou seja, tornar possível o seu retorno à sociedade sem que ele volte à criminalidade. É principalmente levar cidadania a essas pessoas, é mostrar para elas um caminho novo, e nada melhor do que educação como instrumento para esse processo, dar a esses seres humanos uma chance nesse mercado extremamente competitivo e tão assustador quanto eles o são para a maioria da sociedade.

Educação é um fenômeno de produção e apropriação dos produtos culturais, expresso por um sistema aberto de ensino e aprendizagem, constituído de uma teoria de conhecimento referenciada na realidade, com metodologias (pedagogia) incentivadoras à participação e ao empoderamento das pessoas, com conteúdos e técnicas de avaliações processuais, permeados por uma base política estimuladora de transformações sociais e orientados por anseios humanos de liberdade, justiça, igualdade e felicidade.

Prisão (ou cadeia) é um espaço institucional da justiça moderna arquitectado de forma a acolher pessoas condenadas pelos tribunais a cumprir tratamentos penitenciários, pessoas a quem foi decretada judicialmente uma medida de privação de liberdade para efeitos preventivos antes de julgamento ou pessoas detidas e retidas às ordens de forças policiais ou militares.

Fisicamente, o presídio é um local gradeado em suas janelas e portas, seus muros externos são altos e dotados de guaritas de segurança. De acordo com as normas brasileiras quanto à Execução Penal (L.E.P.), as celas devem possuir, no mínimo, $6 \mathrm{~m}^{2}$, ventilação adequada (arejadas) e condições humanas de sobrevivência para os seus atuais e futuros ocupantes.

As ações de ressocialização de apenados buscam reduzir os níveis reincidência e auxiliam na consequiente recuperação do detento através de sua educação, capacitação profissional e da assistência sistemática à sua condição psicológica e social.

Uma das principais questões evidenciadas no estudo foi à forma pelas quais os diversos agentes envolvidos na execução penal compreendem a educação no Sistema Penitenciário. Todos os entrevistados, unanimemente, reconheceram a sua importância e creditam à educação o papel de contribuir com a "ressocialização" do interno penitenciário, conduzindo-o para a sua reinserção social. Muitos associam a educação ao trabalho, dizendo que somente através de uma educação profissional conseguiremos verdadeiramente reintroduzir o interno na sociedade. 
"A educação é um fator primordial na ressocialização do detento. O preso quando é colocado em liberdade, precisa muito ser inserido no mercado de trabalho e a educação é um fator fundamental nesta questão. (...) Existem pessoas que dizem que gastamos dinheiro com o preso. Eu acho que a educação é o melhor investimento que fazemos no detento. Porque se nós não fizermos este investimento, quando ele sair daqui vai continuar trazendo problemas para sociedade. Educar não é uma tarefa solitária, a sociedade tem que ser parceira" (Vera Garrot).

O conceito ressocialização, assim como sua compreensão por parte de alguns dos entrevistados em uma avaliação superficial, sugerem proximidade com o senso comum. Tentando problematizar a questão, procuramos entender o significado que preside o uso desse conceito no contexto prisional, visto que é tão comumente utilizado pelos agentes operadores da execução penal quando falam sobre o papel da educação. Trata-se de um termo bastante complexo, que não pode ser definido simplesmente como, por exemplo, reinserção social.

Segundo Capeller (1985), o conceito ressocialização "surgiu com o desenvolvimento das ciências sociais comportamentais, no século XIX, e é fruto da ciência positivista do direito, refletindo com clareza o binômio ideologia/repressão"

(p.129). Para essa autora, o discurso jurídico se apropria do conceito de ressocialização com o sentido de "reintegração social dos indivíduos, enquanto sujeitos de direito" e procura ocultar a ideia do castigo, obscurecendo "a violência legítima do Estado."

"O discurso jurídico sobre a ressocialização e, conseqüentemente, a construção do conceito, nasceu ao mesmo tempo em que a tecnificação do castigo. Quando o 'velho' castigo, expresso nas penas inquisitoriais, foi substituído pelo castigo 'humanitário' dos novos tempos, por uma nova maneira de disposição dos corpos, já não agora dilacerados, mas encarcerados; quando se cristaliza o sistema prisional e a pena é, por excelência, a pena privativa de liberdade; quando se procura mecanizar os corpos e as mentes para a disciplina do trabalho nas fábricas, aí surge, então, o discurso da ressocialização, que é em seu substrato, o retreinamento dos indivíduos para a sociedade do capital. Neste sentido, o discurso dos 'bons' no alto da sua caridade, é o de pretender recuperar os 'maus'”. (Capeller, 1985, 131).

Para refletir sobre o assunto, torna-se necessário que procuremos, em linhas gerais, encontrar um significado que possa dar sentido ao referido conceito.

Nos principais dicionários de Língua Portuguesa, "ressocialização" é definido como "ato ou efeito de ressocializar". Já "ressocializar" é como "tornar a socializar".

A Educação de Jovens e Adultos surgiu nos primeiros anos da caminhada desse instituto, Paulo Freire acompanhou e contribuiu para a definição dos seus projetos e programas. Foi assim que nasceu o Movimento de Educação de Jovens e Adultos.

Esse Movimento, muito caro a Paulo Freire por toda a sua trajetória nessa área, é herdeiro da tradição da educação popular e, particularmente, do MOVA-SP, lançado quando ele estava à frente da Secretaria Municipal de Educação do Município de São Paulo (1989-1991). 
Assim que o MOVA-SP foi extinto, em 1993, parte da equipe transferiu-se para o IPF, assumindo a continuidade filosófica, metodológica e prática do trabalho iniciado por Paulo Freire.

O Movimento de Educação de Jovens e Adultos do Instituto Paulo Freire é, hoje, antes de tudo, compromisso contra a discriminação e exclusão de pessoas jovens e adultas analfabetas e a favor da garantia desse direito humano fundamental a toda a população. É um espaço de encontro, de celebração, de solidariedade, de reflexão, formação, pesquisa e publicação em torno das questões que envolvem a educação de pessoas jovens e adultas numa perspectiva cidadã e eco pedagógica.

A Educação de Jovens e Adultos surgiu com o objetivo de desenvolver estudos e pesquisas que contribuam para a formação de educadores e para a definição de políticas públicas. Oferecer formação inicial e continuada, presencial e a distância, de educadores de EJA, numa perspectiva transformadora. Participar de movimentos de luta, nacionais e internacionais, pela melhoria do atendimento à EJA. Organizar publicações na área de EJA que contribuam para manter vivo e atualizar o pensamento freiriano, bem como oferecer subsídios para as reflexões e práticas educativas nesse nível de ensino. Organizar e participar de eventos nacionais e internacionais que contribuam para o encontro de pessoas, reflexões coletivas, sistematização e fortalecimento de experiências em torno da educação de pessoas jovens e adultas.

A Educação de Jovens e Adultos deve ser sempre uma educação multicultural, uma educação que desenvolva o conhecimento e a integração na diversidade cultural, como afirma Freire (1979), uma educação para a compreensão mútua, contra a exclusão por motivos de raça, sexo, cultura ou outras formas de discriminação e, para isso, o educador deve conhecer bem o próprio meio do educando, pois somente conhecendo a realidade desses jovens e adultos é que haverá uma educação de qualidade.

Considerando a própria realidade dos educandos, o educador conseguirá promover a motivação necessária à aprendizagem, despertando neles interesses e entusiasmos, abrindo-lhes um maior campo para o atingimento do conhecimento. $\mathrm{O}$ jovem e o adulto querem ver a aplicação imediata do que estão aprendendo e, ao mesmo tempo, precisam ser estimulados para resgatarem a sua auto-estima, pois sua "ignorância" lhes trará ansiedade, angústia e "complexo de inferioridade". Esses jovens e adultos são tão capazes como uma criança, exigindo somente mais técnica e metodologia eficientes para esse tipo de modalidade.

\subsection{HIPÓTESES}

\subsubsection{HIPÓTESE 1}

Existe a possibilidade de a educação prisional ministrada no MERCOSUL na Escola da Unidade Prisional de Bom Jesus contribuir como um dos instrumentos para recuperar e reinserir os detentos de volta na sociedade.

\subsubsection{HIPÓTESE 2}

É possível que o ensino prisional ministrado na escola da Penitenciária de Bom Jesus com base na realidade local do detento possa desenvolver a sua capacidade crítica e criadora levando a sua recuperação e transformação na vida do reeducando. 


\section{METODOLOGIA DA PESQUISA}

Com o objetivo de contribuir com a discussão sobre a política de execução penal brasileira, este trabalho, propondo abordar algumas questões que envolvem a educação para detentos do sistema penitenciário como programa legal de ressocialização, procurou compreender o papel que a educação básica desempenha no sistema penitenciário, buscando descrever e analisar as relações entre educação básica e "ressocialização" dentro de um sistema penal. Desse modo, procurou-se analisar a versão oficial sobre a política de educação desenvolvida nos presídios; a percepção que os professores têm a respeito dessa política; e como os internos penitenciários analisam a educação da qual participam. Teve-se como proposta central, desenvolver uma análise documental e uma coleta de relatos orais a respeito do modelo de política pública de educação penitenciária aplicado na Unidade Prisional de Bom Jesus, Estado do Piauí, Brasil.

\subsection{DESCRIÇÃO DO LUGAR DO ESTUDO}

O Piauí situa-se na Região Nordeste do Brasil com uma população estimada de 3.006.885 de habitantes, de acordo com o Censo Demográfico de 2007, realizado pelo IBGE. A Densidade Demográfica é de 11,31 habitantes por $\mathbf{k m}^{2}$, com área de $252.378 \mathbf{k m}^{2}$, representando $16,17 \%$ da Região Nordeste e $\mathbf{2 , 9 5 \%}$ de todo o território brasileiro. O Índice de Desenvolvimento Humano (IDH) é de $\mathbf{0 , 6 5 6}$ segundo o Atlas de Desenvolvimento Humano/PNUD (2000).

Bom Jesus é um município brasileiro do Estado do Piauí, sua população estimada em 2007 é de 19.575 habitantes segundo o recente censo do IBGE. A cidade de Bom Jesus tem passado por um período de rápido crescimento populacional e econômico em função da expansão na área agrícola. $\mathrm{Na}$ década de 1990, produtores de soja do Rio Grande do Sul começaram a chegar e a cultivar soja no cerrado do Piauí, principalmente em Bom Jesus e Uruçuí. Hoje, aproximadamente 220 mil hectares são cultivados com soja, arroz e algodão nessa região, considerada a última fronteira agrícola do Brasil. Localizada na região do Vale do Rio Gurguéia, a cidade é muito rica em água subterrânea. Os poços jorrantes (a água sai sem precisar de bombeamento) são abundantes.

Tomamos como experiência a Penitenciária Regional Dom Abel Alonso Núñez localizada na BR-135, Km 3,7, Localidade Vila Estela, cidade de Bom Jesus, Estado do Piauí, Brasil, Unidade Prisional que dispõe apenas de vagas para o sexo masculino com capacidade para 76 (setenta e seis) detentos, por ter sido o primeiro Gerente da Unidade Prisional durante os anos de 2004, 2005 e os três primeiros meses do ano de 2006, quando implantamos em 18 de setembro de 2004 o Projeto "Educando para a Liberdade" contemplando inicialmente 20 (vinte) alunos, sendo que no dia 28 (vinte e oito) de setembro do mesmo ano foi procedido diagnóstico para o desmembramento da turma adotando-se o critério de separação entre alfabetização e segundo ciclo $3^{\mathrm{a}}$ e $4^{\mathrm{a}}$ séries de educação de jovens e adultos, atividades educativas que tinham a frente a pedagoga Ivone Antônia da Silva e Marilene de Matos Rosal licenciada em letras/português.

No ano de 2005 o Projeto "Educando para a Liberdade" aumentou o número de alunos para 30 (trinta) reeducandos, sendo uma turma de primeira etapa $\left(1^{\mathrm{a}}\right.$ e $2^{\mathrm{a}}$ séries $)$ e outra turma de segunda etapa $\left(5^{\mathrm{a}}\right.$ e $6^{\mathrm{a}}$ séries) de educação de jovens e adultos e uma turma de alfabetização (Alfabetização Solidária) a cargo da professora Maria Fátima Lopes de Oliveira. O Gerente da $14^{a}$ Gerência Regional de Educação da cidade de Bom Jesus professor de matemática José Antônio Alves Piauilino passou a ser professor voluntário e 
ministrou a disciplina de matemática uma vez por semana dentro do citado projeto.

A Escola da Penitenciária Regional de Bom Jesus atualmente conta com 25 (vinte e cinco) detentos estudando, os reeducandos frequentam o Programa de Educação de Jovens e Adultos - EJA que funciona em três etapas: Primeira Etapa ( $1^{\mathrm{a}}$ e $2^{\mathrm{a}}$ Séries), Segunda Etapa $\left(3^{\mathrm{a}}\right.$ e $4^{\mathrm{a}}$ Séries $)$ e Terceira Etapa $\left(5^{\mathrm{a}}\right.$ e $6^{\mathrm{a}}$ Séries).

As disciplinas ministradas todas são da Educação de Jovens e Adultos - EJA: Matemática, Geografia, História, Inglês, Português, Relações Humanas, Ensino Religioso, Artes (artesanato), sendo que as disciplinas de História e Geografia estão voltadas para a realidade local.

A disciplina Relações Humanas trabalha a parte social, a vida após a saída da Penitenciária, regras de comportamento e de convivência social.

A disciplina de português procura através do estimulo a leitura de livros, revistas e jornais despertar e incentivar o gosto pela leitura.

O horário das aulas da Escola da Penitenciária e no turno da manhã entre as 08h00min e às $11 \mathrm{~h} 30 \mathrm{~min}$ de segunda a sexta-feira.

\subsection{FONTES DE DADOS}

O Estudo utilizou fontes primárias como enquête e questionários, fontes secundárias de pesquisa de campo, relatórios, arquivos, livros e fotos.

\subsection{TIPO E MÉTODO DE ESTUDO}

\subsubsection{TIPO}

O desenho desse estudo é não experimental, transversal, de tipo descritivo. A pesquisa foi sem manipular deliberadamente as variáveis trata-se de uma pesquisa em que não fazemos variar intencionalmente as variáveis independentes. $\mathrm{O}$ modelo é transversal por que o procedimento consiste em situar um grupo de pessoas num contexto analisando um fenômeno e proporcionando sua descrição (Hernandez-Sampieri et al., 2006, p. 208). O que fazemos é observar fenômenos tal como se produzem em seu contesto natural para depois analisá-lo. Os dados coletados foram em um só momento em um tempo único. Seu objetivo foi descrever variáveis e analisar sua incidência e sua inter-relação em dado momento. O estudo é descritivo porque busca especificar propriedades e características importantes da educação como um dos instrumentos de recuperação de detentos medi e coleta informações de maneira independente

\subsubsection{MÉTODO}

O método de estudo é o qualitativo e quantitativo, considerando que foram realizados registros narrativos obedecendo a um padrão técnico, procurando ser um mecanismo que oferecesse subsídios para análise temática do conteúdo.

\subsection{POPULAÇÃO E AMOSTRA}




\subsubsection{POPULAÇÃO}

A Penitenciária Regional de Bom Jesus dispõe apenas de vagas para o sexo masculino, com capacidade para acolher 76 (setenta e seis detentos), possui dois pavilhões, módulo de ensino (escola), módulo de visita íntima, módulo ecumênico, módulo de guarda externa e prédio amplo onde funciona a administração da Unidade Prisional.

Os 25 (vinte e cinco) reeducandos do Módulo de Ensino do Projeto "Educando para a Liberdade" da Penitenciária Regional Dom Abel Alonso Núñez de Bom Jesus, Estado do Piauí, Brasil.

\subsubsection{AMOSTRA}

Tomou-se como amostra os 25 (vinte e cinco) reeducandos que frequentam o módulo de ensino, o conjunto de reeducandos do Módulo de Ensino do Projeto "Educando para a Liberdade" da Penitenciária Regional Dom Abel Alonso Núñez de Bom Jesus, Estado do Piauí, Brasil, esclarecer que nesse caso tomou-se como amostra todos os alunos que frequentam o módulo de ensino.

\subsection{TÉCNICAS DE COLETA DE DADOS}

Feita mediante a manipulação de certas condições e a observação dos efeitos produzidos, sendo realizadas obedecendo a um padrão técnico, procurando ser um mecanismo que oferecesse subsídios para análise temática do conteúdo.

Utilizaram-se questionários, entrevistas com alunos e ex-alunos, professores, agentes penitenciários (guarda interna), militares (guarda externa), coordenadores, administração, gerência, fez-se uso de fontes bibliográficas, pesquisas no arquivo da Penitenciária Regional Dom Abel Alonso Núñez, procedeu-se levantamentos dos relatórios e formulários mensais do INFOPEN - Sistema de Informação Penitenciário Nacional.

\subsection{TÉCNICAS DE ANÁLISES DE DADOS}

Utilizou-se a análise estatística, representações gráficas. Narração e interpretação da situação atual dos reeducandos e as condições para aumentar a oferta de ensino.

\section{DISCUSSÃO E ANÁLISE DOS RESULTADOS}

\subsection{DADOS DEMOGRÁFICOS DOS REEDUCANDOS}

\subsubsection{GRAU DE ESCOLARIDADE}




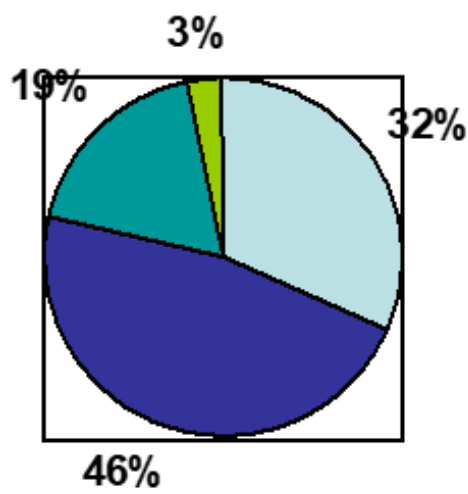

\begin{tabular}{|l}
$\square$ analfabetos \\
$\square$ alfabetizados \\
$\square$ ensino médio \\
$\square$ ensino superior incompleto
\end{tabular}

Gráfico 01 - Grau de escolaridade dos detentos da penitenciária regional de Bom Jesus

O gráfico $n^{\circ} .1$ demonstra que dos 85 (oitenta e cinco) detentos recolhidos na Penitenciária Regional de Bom Jesus $46 \%$ dos detentos são alfabetizados, enquanto que 32\% são analfabetos, $19 \%$ concluíram o ensino médio e somente $3 \%$ possuem o ensino superior incompleto.

Foucault (1987, p. 224) diz: “A educação do detento é, por parte do poder público, ao mesmo tempo uma precaução indispensável no interesse da sociedade e uma obrigação para com o detento, ela é a grande força de pensar.

\subsection{PROCESSO ENSINO-APRENDIZAGEM}

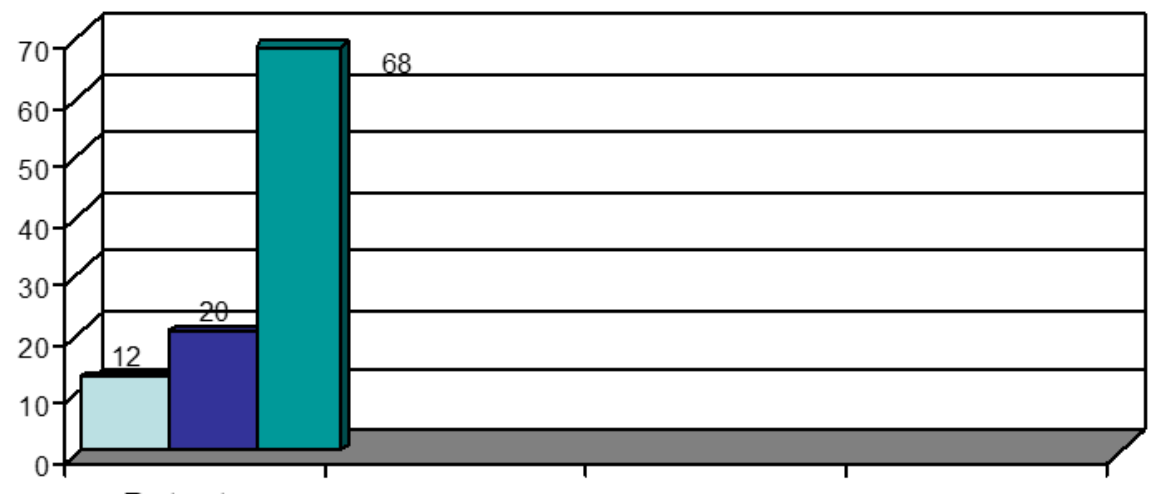

口 não sabem

$\square$ não consideram de qualidade

$\square$ consideram de qualidade

Gráfico 2 - Avaliação do processo ensino-aprendizagem pelos detentos (reeducandos) da escola da Penitenciária

A População avaliada são os 25 (vinte e cinco) detentos que frequentam a Escola da Penitenciária Regional de Bom Jesus. Tomou-se como amostra o conjunto da população de detentos que frequentam a Escola.

No gráfico $\mathrm{n}^{\mathrm{o}} .2$ se observa que $68 \%$ dos detentos considera satisfatório e de qualidade o processo-ensino aprendizagem da Escola da Penitenciária de Bom Jesus, para 20\% consideram que deve ser melhorado o 
processo ensino-aprendizagem e uma pequena parcela 12\% não soube opinar.

"Educação autêntica, que não descuide da vocação ontológica do homem, a de ser sujeito" (Freire, 1979, p. 66)

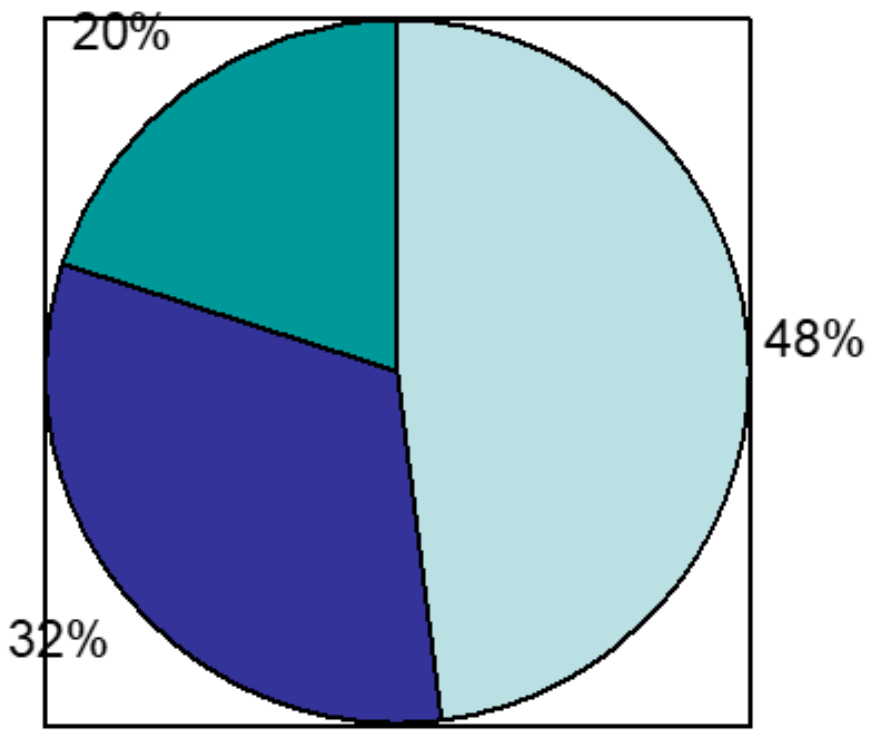

$\square$ voltado para a realidade $\square$ não é voltado

$\square$ não sabe

Gráfico 3 - Processo ensino-aprendizagem voltado para a realidade do detento

O gráfico de $n^{\circ} .3$ informa que para $48 \%$ dos detentos que frequentam a Escola da Penitenciária Regional de Bom Jesus o processo ensino-aprendizagem é voltado para a realidade do detento, para 32\% o processo ensino-aprendizagem não é voltado para a realidade do detento e $20 \%$ dos detentos que frequentam a Escola não souberam opinar.

Mirabette (1993: p.lxxxv):

“A assistência educacional deve ser uma das prestações básicas mais importantes não só para o homem livre, mas também àquele que está preso, constituindo-se, neste caso, em um elemento de tratamento penitenciário como meio para a reinserção social". 


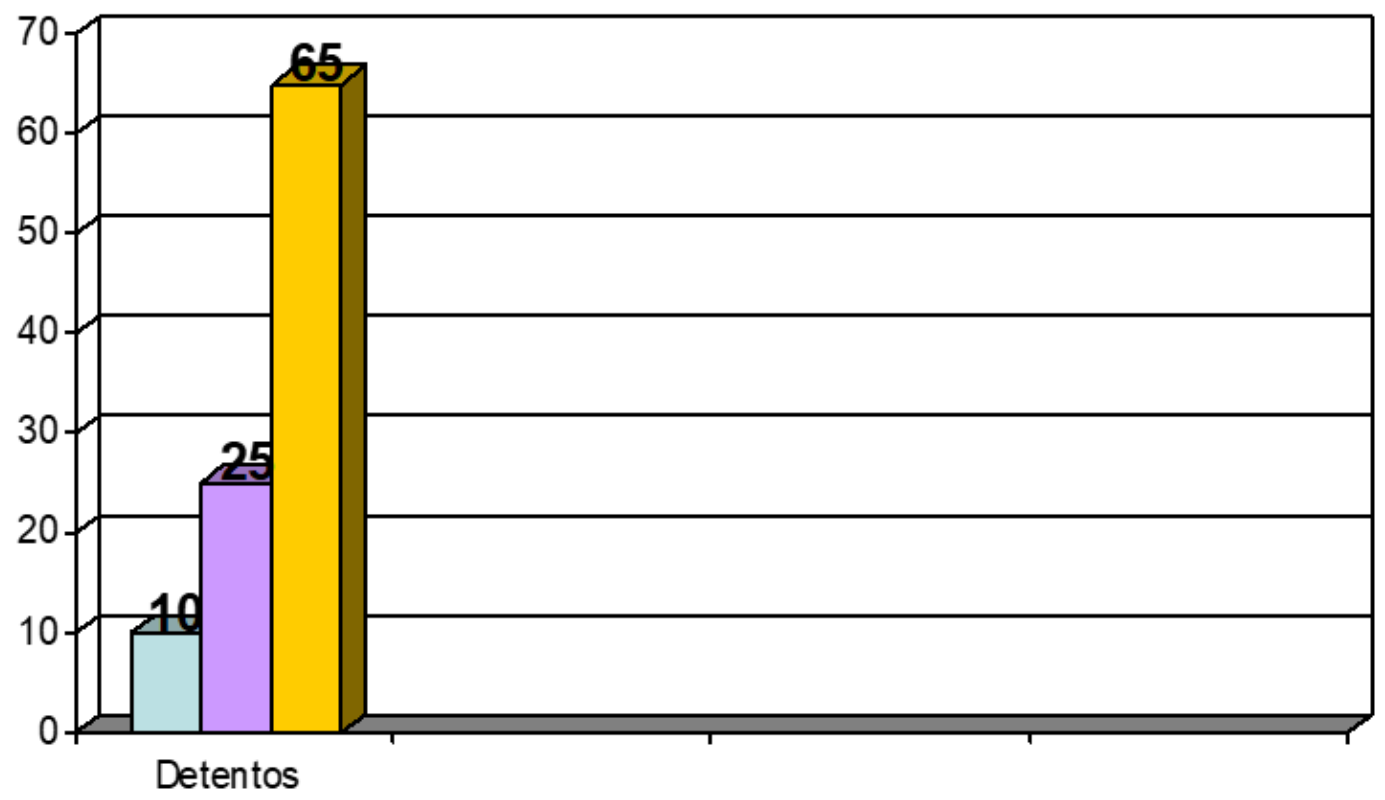

Gráfico 4 - Avaliação dos detentos sobre a carga horária da escola da Penitenciária Regional de Bom Jesus

Informa o gráfico de $\mathrm{n}^{\circ} .4$ que para $65 \%$ dos detentos que frequentam a Escola da Penitenciária a carga horária é suficiente para ministrar todos os conteúdos ao longo do ano, para $25 \%$ dos detentos a carga horária é insuficiente para ministrar todos os conteúdos ao longo do ano e $10 \%$ não souberam responder ou não sabem avaliar.

Gadotti (in: Educação, 1999, p. 62) diz que "Educar é libertar [...] dentro da prisão, a palavra e o diálogo continuam sendo a principal chave. A única força que move um preso é a liberdade; ela é a grande força de pensar." 


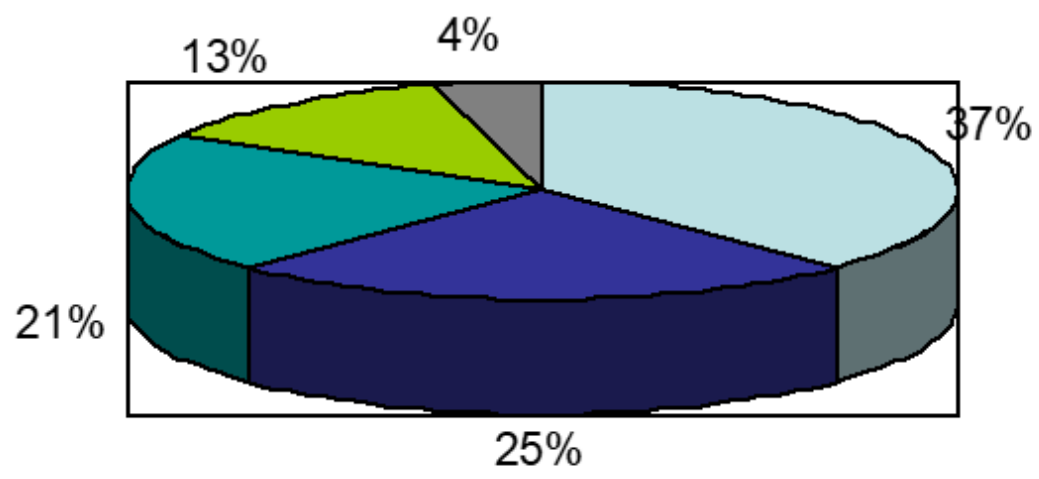

$\square$ melhorar o
relacionamento
com os agentes
o ensino voltado
para a realidade
$\square$ melhores
equipamentos
$\square$ aumento da carga
horária
$\square$ não sabe

Gráfico 5 - O que pode ser feito para melhorar o processo ensino-aprendizagem segundo os detentos (reeducandos) frequentam a escola da Penitenciária

O gráfico de $\mathrm{n}^{\mathrm{o}} .5$ demonstra que para $37 \%$ dos detentos que frequentam a Escola da Penitenciária o que pode ser feito para melhorar o processo ensino-aprendizagem é a melhoria no relacionamento dos agentes penitenciários com os detentos reeducandos que frequentam a escola, para $25 \%$ o ensino ministrado deve ser voltado para a realidade carcerária do detento, para $21 \%$ a escola deve ter melhores equipamentos e material didático, $13 \%$ entende que deve ser aumentada a carga horária para melhorar o processo ensinoaprendizagem e $4 \%$ não souberam responder.

"Controle técnico da detenção - a gestão das prisões, seu regime, deve ser realizado por pessoal capacitado, que zele pela boa formação dos condenados” (Foucault, 1986, p. 221). 


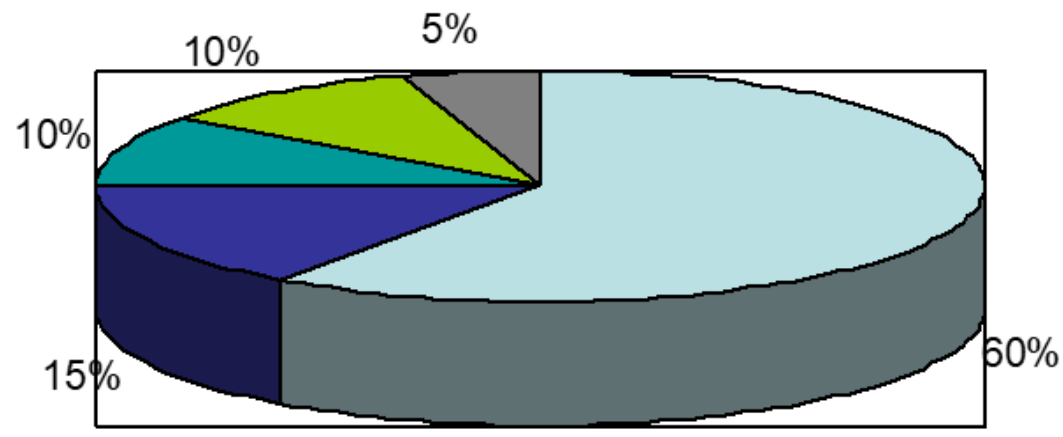

$\square$ aumentar o número de agentes penitenciários

aumentar o número de professores

aumentar a segurança da penitenciária

$\square$ vontade da gerência

não sabe

Gráfico 6 - O que pode ser feito para aumentar as vagas na escola da penitenciária segundo os detentos

O gráfico de $\mathrm{n}^{\circ} .6$ demonstra que para $60 \%$ dos detentos que freqüentam a Escola da Penitenciária o que pode ser feito para aumentar as vagas para os detentos na Escola da Penitenciária seria o aumento do número de agentes penitenciários, para $15 \%$ seria aumentar o número de professores, para $10 \%$ seria o aumento da segurança da Unidade Prisional, para $10 \%$ seria pela vontade do Gerente da Unidade Prisional que determinaria o aumento e 5\% não souberam responder.

Mirabete (2002) mencionando o artigo 205 da Constituição Federal que elege "educação, direito de todos e dever do Estado e da família, será promovida e incentivada com a colaboração da sociedade, visando o pleno desenvolvimento da pessoa, seu preparo para o exercício da cidadania e sua qualificação para o trabalho" 


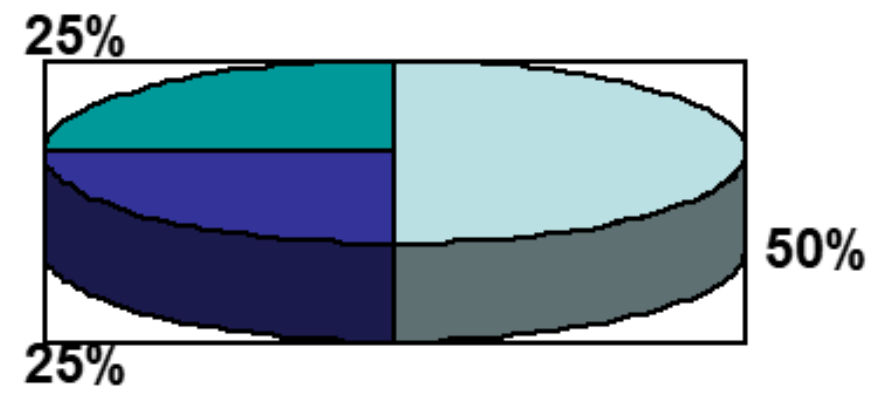

\section{$\square$ ensino- \\ aprendizagem \\ voltado para a \\ realidade do \\ reeducando \\ $\square$ melhorar \\ relacioname nto age nte/reeducando}

\section{senbilizar para a importancia da educação}

Gráfico 7 - O que pode ser melhorado para que o processo ensino-aprendizagem e a carga horária atendam seus objetivos segundo os professores

O gráfico de $\mathrm{n}^{\circ} .7$ demonstra que para 50\% dos professores que lecionam na Escola da Penitenciária o que pode ser feito para melhorar o processo ensino-aprendizagem e a carga horária é um processo ensinoaprendizagem voltado para a realidade do reeducando, para $25 \%$ melhorar o relacionamento agente penitenciário/reeducando e $25 \%$ sensibilizar o sistema penitenciário para a importância da educação como instrumento de recuperação de detentos.

Nesse aspecto, Gadotti (in: Educação, 1999, p. 62) salienta a necessidade de trabalhar no reeducando "[...] o ato anti-social e as consequiências desse ato, os transtornos legais, as perdas pessoais e o estigma social." Em outras palavras, desenvolver nos educandos a capacidade de reflexão, fazendo-os compreender a realidade para que de posse dessa compreensão possam então desejar sua transformação. Assim como saliente o artigo... "[...] uma educação voltada para a autonomia intelectual dos alunos, oferecendo condições de análises e compreensão da realidade prisional, humana e social em que vivem". 


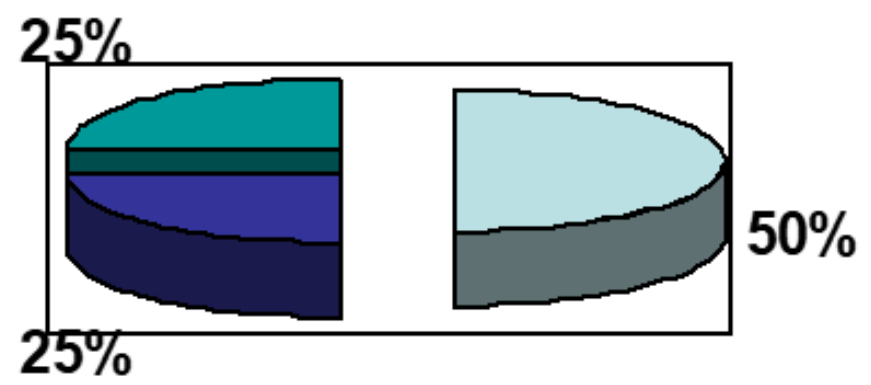

\begin{tabular}{|l|}
\hline trabalhar a \\
autoestima dos \\
reeducandos \\
$\square$ ensino prepare \\
para a vida após a \\
prisão \\
melhorar a relação \\
agente/reeducando \\
\hline
\end{tabular}

Gráfico 8 - O que pode ser modificado na área de ensino e aprendizagem para melhorar o aproveitamento dos reeducandos segundo os professores

O gráfico de $n^{\circ} .8$ demonstra que para $50 \%$ dos professores que lecionam na Escola da Penitenciária o que pode ser modificado na área de ensino e aprendizagem para melhorar o aproveitamento dos reeducandos seria trabalhar a autoestima dos reeducandos, para 25\% um ensino que prepare para a vida após a prisão e $25 \%$ melhorar a relação agente penitenciário reeducando.

Indivíduo "reabilitado", portanto, seria o infrator plenamente ajustado ao aparelho carcerário; especificado e patologizado técnica e cientificamente em face da sociedade - "preso um dia, preso toda a vida" (Castro et al., 1984, p. 110). 


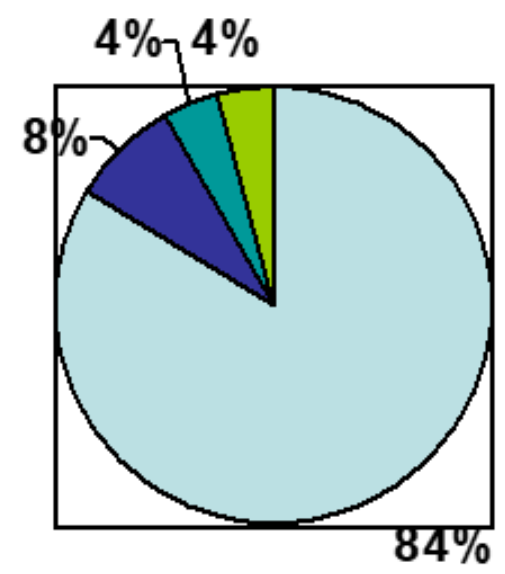

ensino para desenvolver as qualidades e aptidões dos reeducandos

$\square$ ensino de acordo com a realidade carcerária

\section{ensino crítico e conscientizador}

\section{contratar mais agentes penitenciários}

Gráfico 9 - O que pode ser modificado na área de ensino e aprendizagem para melhorar o aproveitamento dos reeducandos segundo o gerente da Penitenciária

O gráfico de $\mathrm{n}^{\circ} .9$ demonstra que para o gerente da Penitenciária Regional de Bom Jesus o que pode ser modificado na área de ensino aprendizagem para melhorar o aproveitamento dos reeducandos seria $84 \%$ um ensino que possa desenvolver as qualidades e as aptidões dos reeducandos e $8 \%$ ensino voltado para a realidade do reeducando encarcerado, $4 \%$ um ensino crítico e conscientizador e $4 \%$ contratar mais agentes penitenciários para a Unidade Prisional de Bom Jesus.

Fernando Salla (in: Educação, 1999, p. 67) “[...] por mais que a prisão seja incapaz de ressocializar, um grande número de detentos deixa o sistema penitenciário e abandona a marginalidade porque teve a oportunidade de estudar.'

A vida é curta demais para ser pequena. Sim, todavia, uma das mais claras realidades de nosso tempo é a crise em que a humanidade se debate.

Ao fim de mais um milênio, a tecnologia, que levou o homem a conquistar o mundo, não deu solução aos grandes problemas que afligem o espírito humano. E jamais dará, porque eles transcendem de suas rasteiras possibilidades. O homem de hoje sabe muito do universo, mas pouco avançou no conhecimento de suas origens e de seu destino, embora possa dispor das maravilhas da ciência e de seus limites inatingíveis.

Na verdade, a natureza humana é complexa e opulenta, polimorfa e impossível de ser enquadrada num sistema de coordenadas ou em esquemas invariáveis. Ainda não apareceu um gênio para ensinar como se determina a abcissa da dor ou em que proporção o sofrimento, a paixão, a fé, a ambição, o medo, o amor e o ódio penetram no mais íntimo da alma. Ainda não se inventou o processo físico de fazer sorrir ou a lágrima brotando da composição química dum laboratório. 
A técnica deu aos países do Primeiro Mundo o conforto, o bem-estar e a abundância. Tudo isso é bom, mas não basta. Ela não evitou o aumento da violência, o choque das raças, o genocídio, a proliferação do narcotráfico, a engrenagem da corrupção, o desemprego, o gangsterismo, a miséria maior dos pobres, a mortalidade infantil e tantos outros males, como o desencadeamento duma violência e duma insegurança nunca dantes conhecidas.

Faz parte dessa problemática o peso dos juros da dívida social potencializado na imagem negativa que a população tem da polícia, da Justiça e do Legislativo, quando nessas instituições o povo deveria encontrar os parceiros necessários e úteis à prática do respeito aos direitos humanos, com proteção eficaz e cultivo da prometida bem-aventurança.

Chegamos ao século XXI sem que nenhum país possa mostrar, com clareza, que conseguiu resolver todos os problemas penitenciários, com a prisão ou sem ela.

É certo que, aqui ou ali, pode-se encontrar uma ou outra experiência bem-sucedida. Contudo, no conjunto mundial, o panorama geral é ruim, sobretudo nos países do Terceiro Mundo, daí se concluir que qualquer estabelecimento penal de bom nível representa apenas uma ilha de graça num mar de desgraças.

Sair da prisão é encontrar a possibilidade de abandonar um processo de morte por outro de vida. Por isso vale a pena ficarmos atentos às alternativas penais que estão surgindo, sobretudo para os soft crimes, diante da expectativa geral pela descoberta ou inauguração dum novo estilo de pena, em condições de respaldar um decisivo movimento de respeito e reconhecimento à dimensão humana da imensa legião de pessoas condenadas pela Justiça Penal. As modernas reações penais, sobretudo as penas comunitárias, não devem ser vistas como política de clemência legislativa, e sim como autênticas fórmulas de tratamento bem definido, com variedade de procedimentos aptos a dar adequada resposta a problemas específicos das zonas de delinquência.

Não há prisão feliz, pois ninguém escolhe a prisão para ser sua dream house, especialmente porque a privação da liberdade não evita nascer rusgas na alma e não permite nenhum equilíbrio entre o corpo e o espírito, em ambiente de intensa carga negativa, onde as pessoas estão sempre a mostrar e a refletir dor ou sofrimento, na batalha diária da sobrevivência e da incessante internalização dos apodrecidos valores da vida carcerária, que inviabilizam qualquer capacidade de superação. É por isso que a reabilitação pretendida pela legislação penal, em todos os lugares do mundo, tem patenteado, na prática, o desalento, a aflição e a definitiva rebeldia contra uma sociedade que fecha as portas ao egresso, quando chega o tempo do le lendemain de la peine, na elegante expressão dos franceses. A prisão continua, assim, a procurar um futuro novo capaz de viabilizar medidas práticas de execução penal que correspondam aos anseios da reinserção social e moral.

Eis a razão pela qual se diz, a todo instante, que a prisão:

a) não serve para o que diz servir;

b) oferece o máximo de promiscuidade;

c) neutraliza a formação e o progresso de bons valores;

d) estigmatiza o ser humano;

e) funciona como máquina de reprodução da carreira no crime;

f) introduz na personalidade a prisionalização da nefasta cultura carcerária; 
g) estimula o processo de despersonalização;

h) legitima o desrespeito aos direitos humanos;

i) destrói a família do condenado.

Ao contrário, para realizar plenamente os seus fins, a pena de prisão deve ser:

a) proporcional à gravidade do crime e à culpabilidade do agente;

b) impulsora do senso de responsabilidade;

c) eficaz na defesa da sociedade;

d) reparadora do dano causado;

e) exemplar para todos;

f) tranquilizadora dos homens de bem;

g) medicinal para o próprio delinquente;

h) alicerce para o exercício sadio da cidadania;

i) caminho para a retomada dos sonhos na vida familiar e comunitária.

Ponto de partida para uma política penitenciária justa e eficiente é, portanto, o de que a prisão, muito além da sua natureza aflitiva, deve ser a base da restauração pessoal, para quem nela vive carente de boas oportunidades. Daí a imprescindibilidade de servidores penitenciários com senso crítico, formação e treinamento contínuo que garantam a capacidade técnica de viabilizar a pedagogia da reinserção social.

Essas considerações suscitam um grave problema: a pena justa é praticamente alcançável?

É fácil teorizar; difícil é pôr em prática. Mas não devemos nos contentar com que a justiça reine em alturas inatingíveis. Se, por um lado, é vã a pretensão de realizar um Direito Penal olímpico, por outra parte não devemos renunciar à busca de uma solução razoável e que se aproxime o mais possível do ideal. Em outras palavras, temos de agir como em matemática: por aproximações. Para isso devemos confrontar o proveito ilícito buscado pela vontade depravada do delinquente com o sacrifício que o castigo lhe imporá.

De que valeria, por exemplo, infligir uma pena infamante para quem, voluntariamente, degradou o próprio nome nos caminhos do vício?

Enfim, a solução para os problemas que afetam o sistema penitenciário, em todos os Continentes, só será obtida se baseada na convicção de que esta não é uma questão isolada, estanque. Ao contrário, necessita ser entendida como um verdadeiro sistema de vasos comunicantes, fundamentada em quatro pontos: a justiça social; o sistema policial; o sistema judiciário; e o sistema penitenciário. Além disso, exige uma ampla discussão a envolver todos os segmentos sociais, cujos componentes não devem continuar contaminados e imobilizados pelo preconceito e pela indiferença.

Tanto o Governo como a opinião pública precisam se preparar com políticas eficientes para encarar a questão penitenciária como componente relevante do progresso científico e tecnológico, considerando que faz parte de uma sociedade justa, equitativa, educada e economicamente expressiva, saber dar conta dessa problemática com seriedade, determinação e competência. Preso e sociedade sempre terão de conviver como vizinhos decentes, ainda que estipulando fronteiras. Não precisa ser uma cena de Dostoievski, de irmãos se abraçando, mas uma convivência de compreensão e tolerância, na rota dum 
consensualismo em condições de aproximar o delinquente da vida normal dos cidadãos.

Veja-se, por oportuno, que o povo brasileiro assiste à proliferação de gangues rivais de presos e à ascensão de facções criminosas que comandam operações dentro dos estabelecimentos prisionais, com impressionante capacidade de organização para promover rebeliões, impor o terror, intimidar o Governo e espantar a sociedade. Agem com a conveniência de funcionários corruptos, ditam regras para os presos e vivem conectados com os crimes que ocorrem fora das prisões, especialmente sequestros, assaltos e tráfico de drogas. Já fazem parte da crônica penitenciária do Brasil duas ousadas facções criminosas: o Comando Vermelho - CV, com sede no Complexo Penitenciário de Bangu, no Rio de Janeiro, e o Primeiro Comando da Capital - PCC, com quartel-general fixado no Complexo Penitenciário do Carandiru, em São Paulo. Hoje, os maiores problemas do sistema prisional brasileiro são: o crime organizado, a corrupção, a superlotação, a ociosidade e a baixa inteligência na administração dos estabelecimentos prisionais.

A questão não reside, simplesmente, na redução da massa prisional, uma vez que o esvaziamento dos cárceres não deve pagar o alto preço do afrouxamento da repressão. Compatibilizar o ideal duma cadeia humana com a necessidade de assegurar a coibição dos delitos não é tarefa de fácil realização. Igualmente difícil é a empreitada de oferecer ao preso tudo quanto ele precisa em matéria de assistência, de educação criativa, de cultura, de ocupação com trabalho produtivo, de respeito às convicções religiosas, de relação com a família, com a sociedade e de reconhecimento aos seus direitos não atingidos pela sentença criminal, preparando o futuro para, em liberdade, prover com honradez e autonomia sua subsistência.

Desse modo, é possível enfrentar, com firmeza, as fortes rejeições ao tradicional modelo fracassado de prisão à espera de nova fisionomia, em condições de reeducar o preso para o exercício da cidadania responsável, de maneira a respeitar os direitos dos outros e se dispor a arcar com a solidariedade e os sacrifícios exigidos pelo bem comum.

Esse processo de retomada é longo, requer empenho e imposição nítida de limites. Sob pena de cair no vazio.

No Brasil, algumas experiências de sucesso permanecem pouco divulgadas. Contudo, três modelos parecem apontar os caminhos que uma política de reintegração pode seguir. O primeiro exemplo é a Penitenciária Industrial de Guarapuava, localizada na cidade de Guarapuava, Paraná, na qual é desenvolvido um programa, através da parceria público-privado, onde o Estado se responsabiliza pela administração e segurança interna e a empresa envolvida oferece ensino profissionalizante e trabalho qualificado dentro do presídio. Desta forma, elimina-se a ociosidade do apenado, contribui-se para a sua socialização e, simultaneamente, as despesas públicas são reduzidas.

Outra experiência de sucesso existente em muitos estados do país é a parceria entre os executivos estaduais e uma organização não-governamental (ONG) denominada Associação de Proteção e Assistência aos Condenados (Apac). Neste modelo, o Estado constrói a unidade penitenciária e, quando a inaugura, transfere sua gestão para Apac, permanecendo, contudo, na função de prover tanto a segurança como a alimentação dos apenados. Com experiência pioneira em São José dos Campos, este tipo de parceria consiste na seleção dos reclusos para transferi-los de delegacias para a unidade, considerando uma homogeneidade em relação ao perfil criminal e contando com a participação da família desses apenados em atividades desenvolvidas pela ONG dentro e fora da unidade prisional, como programas de 
geração de renda. A permanência do interno na unidade é baseada na reconstrução da sua família e no entendimento de que ele deve recompensar a sociedade pelo seu delito.

Uma terceira experiência, desde 1999, na Penitenciária Estadual de Londrina, é o funcionamento efetivo de uma igreja, na qual alguns funcionários partilham do conhecimento religioso com os internos, estabelecendo uma interação que possibilita o planejamento e a implementação de ações da igreja. A exemplo do modelo Apac, a relação entre funcionários e apenados baseia-se no compromisso e na confiança mútua. Da mesma forma, os internos também são selecionados, a partir de critérios como iniciativa, manifestação de desejo de participar e esperança na reabilitação.

Desta forma, a proposta sugerida pelo Pronasci de edificar unidades prisionais específicas para jovens vem no sentido de minorar os efeitos negativos do inadequado tratamento dado aos apenados no Brasil. Se bem administrado, pode atenuar ainda os resultados perversos de políticas públicas anteriores e desenvolver mecanismos que viabilizem a modificação do cenário existente.

Um consenso obtido é o de que o Estado, sozinho, não é capaz de reintegrar os apenados, especialmente os que se situam na faixa de 18 a 24 anos. Ciente que a existência de presídios está ligada à segregação e aos desajustes de diversas naturezas, a sociedade deve se interessar pelo êxito social do apenado e ceder espaço para sua integração. Para que este objetivo possa ser alcançado, as recentes experiências brasileiras ressaltam a importância do envolvimento da sociedade na realização de políticas públicas de resgate do infrator, implementadas através de iniciativas e parcerias público-privadas com as muitas Ongs brasileiras que já possuem conhecimento acumulado na tarefa de desenvolvimento e implementação de políticas de redução da violência.

O Brasil já coleciona experiências bem sucedidas de ressocialização de presos através de parcerias de governos estaduais com organizações não-governamentais, igrejas e familiares dos presos, que tem como "ingrediente básico" a promoção de redes sociais alternativas. Ou seja, é possível. Neste sentido, o que se pode esperar da administração pública é que assuma o compromisso político com esta proposta, com a definição e planejamento de ações e avaliação dos seus impactos - do contrário vamos continuar convivendo com uma "panela de pressão pronta para explodir", que foi a definição dada por um agente penitenciário aos presídios cariocas. E isto não interessa a ninguém - ou melhor, interessa a muito poucos.

Desde que a prisão tornou-se a pena por excelência, relegando os castigos corporais, os suplícios físicos, desonras, banimentos, esforços extenuantes, etc. (Rocha, 1994), recaiu sobre ela a dupla função de punir e reabilitar.

Fundada nesta dupla finalidade a pena de encarceramento se sedimentou e se proliferou desde os primórdios do século XIX, inicialmente na Europa e, posteriormente, para o restante do mundo.

Considerando a tarefa de reabilitar os indivíduos punidos, áreas diversificadas do conhecimento foram aglutinadas na instituição carcerária para consecução dessa finalidade: arquitetura, sociologia, psiquiatria, serviço social, psicologia, pedagogia e direito.

A reabilitação dos indivíduos por meio do encarceramento, fruto da aglutinação desses saberes, funda-se em três grandes princípios: o isolamento, o trabalho penitenciário e a modulação da pena (Foucault, 
1986). A partir deles tornou-se possível a edificação de um saber técnico-científico sobre os indivíduos, declinando o foco de ação do crime, para aquele que o cometeu. O indivíduo é o foco central da operação penitenciária, não o seu ato.

O princípio do isolamento efetiva-se, primeiro, em relação ao indivíduo transgressor com o mundo exterior. Depois, mediante a classificação dos detentos, um em relação aos outros, dispostos a partir da função de individualização da pena. Essa função é desencadeada tendo em vista o indivíduo punido (não o infrator), objeto de transformação do aparelho carcerário.

Junto ao isolamento, o trabalho é definido como parte constituinte da ação carcerária de transformação dos indivíduos. Impõe-se, não como atividade de produção, mas pelos efeitos que faz desencadear na mecânica humana, proporcionando a ordem e a regularidade; o que sujeita os corpos a movimentos regulares, exclui a agitação e a distração, impõe uma hierarquia e uma vigilância que serão ainda mais bem aceitas, e penetrarão ainda mais profundamente no comportamento dos condenados. (Foucault, 1986, p. 203)

Por fim, o princípio da autonomia penitenciária que permite a modulação da pena, ajustando-a àquela transformação, uma vez que a duração do castigo não deve relacionar-se diretamente à infração, mas sim à transformação útil do indivíduo, no decorrer do cumprimento da sentença. A operação penitenciária é quem deve controlar os efeitos da punição.

A fim de processar a transformação útil do indivíduo, a prisão deve, simultaneamente, ser o local de execução da pena e de uma sistemática e rigorosa observação dos indivíduos punidos. É a partir desta que os rigores, atenuantes, progressões e regressões da pena serão aplicados.

Tais princípios, desde o surgimento da pena de encarceramento, formaram os fundamentos a partir dos quais foram edificadas as máximas para uma adequada administração penitenciária, ou seja, que lhe proporcionariam a consecução das finalidades de punir e reabilitar o indivíduo transgressor. "Princípios de que, ainda hoje, se esperam efeitos tão maravilhosos, são conhecidos: constituem há 150 anos as sete máximas universais da boa condição penitenciária" (Foucault, 1986, p. 221). São elas:

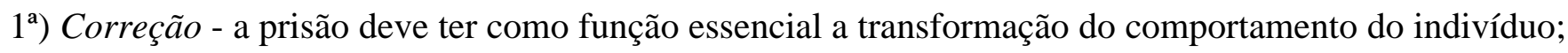
a recuperação e reclassificação social do condenado;

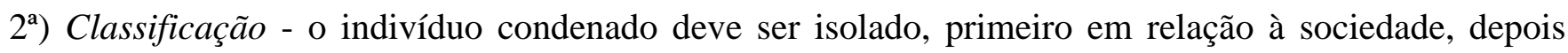
repartidos entre eles, a partir de critérios que envolvam idade, sexo, disposições e técnicas que se pretendam utilizar para que se processe sua transformação, bem como suas respectivas fases para operálas; a pena deve ser não só individual, como individualizante;

$\left.3^{a}\right)$ Modulação das penas - a pena deve ser proporcional, de acordo com a individualidade dos condenados e com os resultados da terapêutica penal, com vistas a se processar sua transformação, prevendo progressos e recaídas inerentes deste processo;

$4^{\text {a) }}$ Trabalho como obrigação e como direito - é considerado como uma das peças fundamentais para transformação e socialização dos detentos, que devem aprender e praticar um ofício, provendo com recursos a si e à sua família; 
$5^{\text {a) }}$ Educação penitenciária - deve ser preocupação diuturna do poder público dotar o indivíduo da educação, no interesse da sociedade, provendo sua instrução geral e profissional;

$6^{\mathrm{a}}$ ) Controle técnico da detenção - a gestão das prisões, seu regime, deve ser realizado por pessoal capacitado, que zele pela boa formação dos condenados;

$7^{\mathrm{a}}$ ) Instituições anexas - o indivíduo deve ser acompanhado por medidas de controle e assistência, até que se processe sua readaptação definitiva na sociedade.

A partir de tais pressupostos, combinando seus efeitos punitivos à operação correcional, a prisão apresenta-se como a instituição de combate ao crime. A constatação de que ela não reduz a criminalidade é tão antiga quanto a própria prisão. Exceto pelos números, as críticas ao seu fracasso permanecem idênticas nos mais de cento e cinqüienta anos de sua existência. Antes de contribuir para a extinção do comportamento criminoso, a prisão produz a reincidência. Afinal, a prisão propicia a organização dos delinquentes, na medida em que desencadeia uma forma de socialização em seu submundo, estabelecendo solidariedade, cumplicidade e hierarquia entre eles.

De forma bastante singular, entretanto, a prisão, invariavelmente apresenta-se como a solução para o problema da criminalidade que ela própria contribui para sedimentar. Sempre acompanhada de planos de reformas, os quais, em seu bojo, reafirmam as máximas que constituíram a prisão desde seu surgimento.

O que justifica a existência capilar da prisão na sociedade, não obstante seu absoluto fracasso em combater a criminalidade, antes que suprimir as infrações, é distingui-las, distribuí-las e até utilizá-las:

Organizar as transgressões numa tática geral de sujeições (...) É uma maneira de gerir as ilegalidades, de riscar limites de tolerância, dar terreno a alguns, de fazer pressão sobre outros, de excluir uma parte, de tornar útil outra, de neutralizar estes, de tirar proveito daqueles (Foucault, 1986, p. 226).

A operação penitenciária, portanto, gerencia a delinquência, inserida numa estratégia global de dominação e disciplinarização - Corrigir as pessoas sempre foi um objetivo estreitamente ligado ao uso que se quer fazer delas (Rocha, 1994, p. 170).

Aspecto central nessa operação é a construção da delinquência que ela faz desencadear nos indivíduos punidos. O condenado - infrator na justiça penal - torna-se o objeto de saber da técnica penitenciária que, em seu lugar, coloca um outro personagem: o delinquente. $O$ infrator se constitui por um ato (transgressor), o delinquente se refere a toda uma vida do indivíduo, objeto de conhecimento da técnica punitiva:

A diferença entre um infrator e um delinquente está em que o que caracteriza o delinquente não é o ato da infração, mas a sua vida. A justiça condena o infrator pelo ato da infração, o sistema carcerário não apenas faz com que a infração o marque pela vida toda, como realiza a socialização que o insere definitivamente no mundo do crime. (Ramalho, 1979, p. 163)

A lenta formação do delinquente transparece na investigação biográfica, fator de extrema importância na história da penalidade, "porque faz existir o criminoso antes do crime" (Foucault, 1986, p. 211). A biografia marca o autor da transgressão com uma criminalidade que, portanto, exige as medidas da ação 
penitenciária. Nesse aspecto, confundem-se o discurso penal e psiquiátrico. No ponto de intersecção desses discursos, surge a noção de indivíduo perigoso, "que permite estabelecer uma rede de causalidade na escala de sua biografia inteira e um veredicto de punição - correção" (Foucault, 1986, p. 211).

Afora a perda da liberdade física (ou do direito de ir e vir), a prisão subjuga o detento ao comando de uma estrutura autoritária e de uma rígida rotina autocrática que opera como uma grande máquina impessoal. $\mathrm{O}$ controle sobre os indivíduos é exercido de forma ininterrupta, regulando-se de modo minucioso todos os momentos de sua vida. Com a nítida orientação de preservar a ordem, a disciplina, evitar fugas e motins, a organização penitenciária elege como forma eficaz submeter o recluso, cercear quaisquer possibilidades do exercício de sua autonomia (Thompson, 1976).

Ao adaptar sua conduta e comportamento às normas e padrões da instituição, o preso gradualmente passa a obter acesso a determinados bens ou prerrogativas na prisão. Certas necessidades, procedimentos ou vontades que na vida fora da prisão eram absolutamente corriqueiras, no interior dela adquirem a qualidade de privilégios: tomar um café quente, ir a algum lugar sem motivo aparente, faltar ao trabalho ou à aula, sair com um grupo ou outro de pessoas, dormir ou acordar em horários diferentes, etc.

Em contrapartida, essa adaptação tende à despersonalização do sujeito apenado - a mortificação de seu eu (Goffman, 1996). Quanto maior a intensidade do ajustamento ao sistema social da prisão, maiores as possibilidades de se alcançar os privilégios de que ela dispõe. Ao contrário, mostrar-se resistente acarreta ao indivíduo punido um maior rigor, severidade e endurecimento de seu regime.

No que concerne à administração penitenciária, o sistema de privilégios é vital para sua gestão, constituindo-se num dos sustentáculos de seu modelo organizacional. Em face da importância que esse sistema representa aos reclusos, inexoravelmente, ele se encerra como uma forma eficaz de controle da massa encarcerada. Comportamentos e condutas não desejáveis pela organização significam o impedimento em obtê-los. Tal controle tende a intensificar-se, pois, no interior das prisões, todas as esferas da vida do indivíduo interpenetram-se. Assim, ser recriminado ou avaliado negativamente em determinada atividade influencia e repercute nas demais, sendo toda sua conduta considerada como não adequada.

É a partir desse pressuposto que o indivíduo passa a organizar toda sua vida encarcerada. Mais que uma motivação, torna-se uma obsessão, que se materializa na inserção em atividades que permitem a remição de pena - trabalho penitenciário - ou nos programas que lhe atribuem a qualidade de uma boa conduta caso da educação e cursos em geral, cultura, esportes e grupos terapêuticos. Manifesta-se também na sua forma de proceder e de relacionar-se com outros presos, funcionários, técnicos e dirigentes. "Se o preso demonstra um comportamento adequado aos padrões da prisão, automaticamente merece ser considerado como readaptado à vida livre" (Thompson, 1976, p. 42).

Nesse sentido, essa busca incessante de mostrar-se adequado aos padrões da prisão transforma-se em princípio e fim das ações dos encarcerados. Os objetivos que, pressupõe-se, deveriam ser inerentes às atividades, seja de educação, cultura, esportes, profissionalização ou terapêuticas, são declinados em favor dessa busca.

Indivíduo "reabilitado", portanto, seria o infrator plenamente ajustado ao aparelho carcerário; especificado e patologizado técnica e cientificamente em face da sociedade - "preso um dia, preso toda a 
vida" (Castro et al., 1984, p. 110).

O sistema punitivo necessita de uma reorganização. Tem que se mudar os métodos arcaicos de tentativa de ressocialização, as penas alternativas têm que sair da ideia para prática, o corpo penal tem de fazer uma reciclagem, a realidade fática que se nos apresenta é diversa da pretendida na Lei Maior Brasileira (Constituição) e pela Legislação Penitenciária. A lei assegura os direitos do preso, mas tais dispositivos legais são esquecidos, visto que o tratamento dispensado aos detentos é precário e o respeito à dignidade humana, infelizmente, são deixados em segundo ou quiçá, último plano. Deve-se tirar o recluso da ociosidade, reeducá-lo, formando a pessoa humana, dando-lhe uma vocação, para reinserí-lo na sociedade. Este tratamento deve vir incumbido de medidas sociológicas, penais, educativas, psicológicas e métodos científicos, de forma integrada numa ação junto ao delinquente, visando modelar a sua personalidade para a sua reinserção social e para prevenir a reincidência.

Promulgada há quase 11 anos, a Lei de Diretrizes e Bases da Educação (LDB) é clara: garantir educação para toda a população brasileira é dever do poder público. Esse direito se estende também àqueles brasileiros temporariamente privados da liberdade. E como tantas outras, essa lei também não sai do papel.

No caso específico da chamada educação prisional, a principal justificativa é a histórica desarticulação entre os ministérios e as secretarias estaduais de Educação e Justiça. Por causa do descompasso, essa formação fundamental tanto para a recuperação como para a reintegração social do presidiário se resume a ações isoladas, desorganizadas, descontinuadas e até assistencialistas.

Resultado: os professores são mal preparados, não conhecem a realidade de seus alunos e a educação oferecida na chamada cela de aula não garante a certificação. Ao final do programa curricular, o detento tem que se submeter aos exames supletivos. Não bastasse isso para desmotivá-lo, estudar na prisão ainda não assegura remição de pena, como acontece com o trabalho. Por isso, apenas $18 \%$ dos detentos que cumprem pena nos presídios brasileiros estão estudando.

Algumas ações, felizmente, já estão sendo tomadas no sentido de reverter essa situação. Nos últimos anos, vários setores ligados à defesa dos direitos da educação de jovens e adultos vêm intensificando as pressões sobre as autoridades para que criem uma lei nacional que ofereça tal benefício. Outra reivindicação é que as autoridades educacionais assumam o controle sobre esse serviço, aumentando o número de vagas e de professores, além de adequar o currículo.

Em 2005, com aval da Unesco e com incentivos financeiros do governo japonês, os ministérios da Justiça e da Educação lançaram o projeto-piloto do programa Educando para a Liberdade em alguns estados. No ano passado, foram realizados seminários regionais e estaduais para debater metas e métodos para a ampliação da oferta desse segmento educacional. O objetivo é que o ensino formal, coordenado pelas secretarias estaduais de educação, seja oferecido em todas as penitenciárias brasileiras.

Um projeto de lei (4.230, de 2004), que tramita no Congresso Nacional e que altera a Lei de Execuções Penais, entre outras coisas estende o benefício da remição penal aos presos que estudam. Sob relatoria da deputada federal Iriny Lopes (PT-ES), o projeto parece que agora avança. O mesmo Projeto havia recebido parecer negativo do deputado Edmar Moreira (PFL-MG), quando foi apreciado na Comissão de Constituição de Justiça na legislatura passada. No entanto, este ano o PL foi desarquivado e, antes de 
voltar à Comissão de Constituição e Justiça, foi encaminhado à Comissão de Segurança Pública e Combate ao Crime Organizado, onde tramita atualmente. Segundo a deputada, serão promovidos encontros e debates com órgãos públicos e ONG's. "Não tenho a menor dúvida de que meu parecer concluirá pelo mérito da proposição, ao contrário do relator anterior", diz.

Mais da metade dos presos de todo o país estão no Estado de São Paulo. A Fundação Prof. Dr. Manoel Pedro Pimentel de Amparo ao Preso (Funap), ligada à Secretaria Estadual de Administração Penitenciária, é responsável pela educação nos presídios. Mantém hoje 380 salas de aulas nas 144 unidades prisionais espalhadas pelo Estado. Dos cerca de 135.454 presos, apenas 11.838 estudam. Menos de $9 \%$ do total. Um levantamento do Instituto Paulo Montenegro, feito há dois anos, revelou que $68 \%$ dos presos paulistas estudaram menos de oito anos. Isso quer dizer que eles não têm o equivalente ao ensino fundamental, o mínimo exigido pela seleção aos postos de trabalho formal.

A educação se fundamenta em um processo básico do ser humano, o preso, nosso objeto será com base nele o início da jornada que se pretende percorrer: o processo da aprendizagem. Como se aprende, o que se aprende e para que se aprende. Eis os alicerces que edificam a vida do homem.

O homem possui uma dimensão de tal grandeza capaz de transformar radicalmente a vida meramente biológica, em algo "qualitativamente" diferente, que se pode chamar de "dimensão simbólica" do mundo: a palavra. Com a utilização da palavra o homem transcendeu os arredores que norteiam o acesso dos sentidos. E vai além, com base no emprego dos símbolos, da palavra. Esta, permite pensar e agir com a consciência de que existe um passado, um presente e um futuro, ou seja, graças ao uso da palavra tem-se a consciência do ontem, do hoje e do amanhã. Portanto, o homem não está preso ao seu corpo visto que tem consciência das dimensões e do tempo. A consciência humana é, pois, produto de sua capacidade simbólica, produto de sua palavra.

Qualitativamente diferentes das demais formas de vida, o homem é portador de uma "consciência reflexiva": pode pensar em si próprio, tomando-se como objeto de seu próprio pensamento o que se verifica graças à palavra. Ele não se adapta simplesmente a um meio: procura transformá-lo, modificá-lo, construí-lo. Faz com que o meio se adapte a ele. Assim ele constrói o mundo "que suplanta a simples dimensão física, que existe também enquanto possibilidade; que existe como um "vir-a-ser", mediante o "sentido" que dá às suas ações; onde a palavra é o primeiro "elemento transformador" do mundo em que vive. Logo, planeja, pensa e age, construindo o que imaginou. Quando o homem abstrai o significado do conceito, e o aplica a diferentes situações, ou seja, aprende um significado, surge a aprendizagem. Mais e mais a significação dos objetos se completa, contribuindo para um todo unificado, ordenado, cuja estruturação significativa é dada pela linguagem. Com a manutenção do significado, do "sentido da vida", chega-se, fundamentalmente, à coerência em um mundo simbólico. A vida tem que fazer sentido. $\mathrm{O}$ homem deve possuir valores, sonhos e ideais, em função dos quais há de se manter vivo.

Fomentar a linguagem, mediante a combinação de seus valores e significados, implica em uma somatória e em um armazenamento de conceitos que o homem aprende; compreendendo-se por referência, as suas próprias experiências anteriores. "Este é então o mecanismo do conhecimento humano: um jogo (dialético) entre o que é sentido (vivido) e o que é simbolizado (transformado em palavras, ou outros símbolos)", ou seja, a experiência social no desenvolvimento da aprendizagem e da linguagem admite analogia ao processo de imitação: quando a criança imita a forma pela qual o adulto usa instrumentos e manipula os objetos, ela está dominando o verdadeiro princípio que envolve uma atividade em particular. 
O uso dos instrumentos especificamente humanos conduz à dialética entre o sentir e o simbolizar.

A educação, no contexto sociocultural, que deveria significar o auxílio aos indivíduos para que pensem sobre a vida que levam; que deveria permitir uma visão do todo cultural onde estão, desvirtua-se na escola. Nesta, as pessoas são preparadas para executar trabalhos parcializados e mecânicos no contexto social. A escola mantém e estimulam a separação da razão e do pensamento, dês que sua finalidade é preparar mão-de-obra à sociedade industrial; transmitir conceitos desvinculados da vida concreta dos educandos, impondo desconsiderar o risco da visão de mundo das classes dominantes. Com efeito, a educação precisa transmitir significados presentes na vida concreta de quem se pretende educar ou reeducar; de modo diverso, não produz resultado, aprendizagem.

Mediante a consciência reflexiva, simbólica, o homem desenvolve a linguagem, utilizando-se da palavra; dá sentido à vida, segundo os significados que advêm fundamentalmente dos símbolos, das palavras, dos nomes. Assim, os conceitos (símbolos) são necessários às experiências dos indivíduos em conexão à realidade. Logo, o processo da aprendizagem precisa mobilizar tanto os significados, os símbolos, quanto os sentimentos, as experiências a que eles se referem.

O Ministério da Educação (MEC) tem desenvolvido projetos nos presídios brasileiros, como o Educando para a Liberdade e o Brasil Alfabetizado. Ainda assim, o número de assistidos é pequeno. Os professores que começam a atuar nos presídios, ficam impressionados com a receptividade dos presos. A imprensa, em geral, só se volta para as carceragens quando acontece alguma coisa ruim, como uma rebelião. Por isso, a sociedade não sabe que pode participar, trazer alguma atividade para esses locais. No Brasil, não há pena de morte e nem prisão perpétua. Os encarcerados vão voltar para o convívio social. Se, quando saírem, não estiverem preparados para ingressar no mercado de trabalho, é pior para toda a sociedade.

A grande maioria dos detentos é jovem. É preciso dar-lhes a oportunidade de retornarem como pessoas dignas. É um absurdo o preso passar pelo Estado e sair analfabeto, sem um documento. Eles pedem para fazer cursos profissionalizantes e artísticos, mas faltam voluntários.

Não se encontra nos colégios municipais ou particulares um público que seja mais interessado do que os presos. É preciso mais investimento do governo, pois é uma contradição querer recuperar presidiários sem projetos sociais. Como uma pessoa analfabeta, que não tem qualificação profissional e carrega o estigma de ex-presidiário pode se inserir na sociedade?

Ressocialização de detentos é fator de segurança social. É dever do Estado e direito consagrado na Constituição Federal e na Lei de Execução Penal. Investir na educação de detentos é fator de humanização, diminui as rebeliões e ajuda a criar um clima de expectativa favorável para o reingresso na vida social, quando em liberdade.

Apoiar medidas que facilitem o acesso dos presos à educação, ao esporte e à cultura, fortalecendo projetos nessas áreas com o estabelecimento de parcerias com organizações não-governamentais e universidades.

- O processo ensino-aprendizagem para a maioria dos reeducandos, professores e gerente é de qualidade e satisfatório cumpre com o seu papel de ensinar os conteúdos de acordo com a realidade dos detentos que frequentam a escola. 
- Para a maioria dos detentos, professores, coordenadores e gerência a carga horária diária e anual é suficiente para uma aprendizagem e para que sejam ministrados todos os conteúdos programáticos.

- Os professores entendem que o número reduzido de agentes penitenciários contribui para dificultar as atividades da escola, bem como os atrasos e os deslocamentos dos detentos para a escola e o aumento de vagas na Escola.

- Os professores entendem que o processo ensino-aprendizagem deve ser melhorado adaptando as disciplinas a realidade dos detentos, a carga horária deve ser seguida de forma rigorosa para que os conteúdos programáticos possam ser ministrados a contento ao longo do ano letivo.

- Os atrasos e descumprimentos dos horários da escola se devem pela falta de vontade e maior dedicação por parte dos agentes penitenciários que deveriam ser mais sensíveis e empenhados com o processo de educação dos detentos.

- O número de alunos da escola é pequeno e poderia ser aumentado com a contratação de mais agentes penitenciários que passaram no último concurso realizado, aumento da segurança da Unidade Prisional, contratação de mais professores daria mais oportunidade para que mais detentos pudessem estudar na escola.

- A Escola se constitui em um dos instrumentos de recuperação dos detentos levantamento feito junto aos relatórios carcerários, prontuários e administração prisional comprovou-se que os reeducandos que frequentam as escolas possuem melhor comportamento carcerário, melhor disciplina, mais tranquilos e dificilmente se envolvem em confusões, brigas ou agressões.

\section{CONCLUSÕES E RECOMENDAÇÕES}

Nesta seção apresentamos as conclusões mais importantes, os objetivos específicos foram alcançados e as hipóteses confirmadas através dos resultados obtidos.

Deve existir garantia de fundos públicos suficientes, para que as pessoas em situação de aprisionamento tenham oportunidades educativas, e essas oportunidades devem corresponder às necessidades específicas das pessoas, razão pela qual é indispensável que a oferta não seja limitada ao ensino fundamental ou vocacional, mas ampliada ao ensino médio e superior. Os Estados devem conhecer, estudar e transpor as barreiras sociais enfrentadas pelas pessoas privadas de liberdade, de modo que a oferta educativa signifique realmente uma oportunidade de liberdade em todos os sentidos.

Organizar junto às instituições penitenciárias programas amplos de educação destinados a desenvolver plenamente as potencialidades de cada recluso, os quais também deveriam minimizar os efeitos negativos do encarceramento, melhorar as perspectivas de reinserção e reabilitação, auto-estima e a moral.

O Governo Federal, por meio dos Ministérios da Educação e da Justiça, figure como o responsável pelo fomento e indução de políticas públicas de Estado no domínio da Educação nas Prisões, estabelecendo as parcerias necessárias junto aos Estados e Municípios.

A oferta de educação no sistema penitenciário seja fruto de uma articulação entre o órgão responsável pela Administração Penitenciária e a Secretaria de Educação que atue junto ao sistema local, cabendo a ambas a responsabilidade pela gestão e pela coordenação desta oferta, sob a inspiração de Diretrizes Nacionais. 
A articulação implique na disponibilização do material pedagógico da modalidade de EJA para as Escolas que atuam no Sistema Penitenciário, como insumo para a elaboração de projetos pedagógicos adequados ao público em questão.

O trabalho articulado encontre as devidas oportunidades de financiamento junto às Pastas Estaduais e aos órgãos Ministeriais, especialmente com a inclusão dos alunos matriculados no Censo Escolar.

A gestão se mantenha aberta a parcerias com outras áreas de governo, universidades e organizações da sociedade civil, sob a orientação de Diretrizes Nacionais.

Os educadores do sistema pertençam, preferencialmente, aos quadros da Secretaria de Educação, selecionados por concursos públicos e com remuneração acrescida de vantagens pecuniárias condizentes com as especificidades do cargo.

A gestão propicie espaços físicos adequados às práticas educativas (p. ex.: salas de aula, bibliotecas, laboratórios etc.), além de adquirir os equipamentos e materiais necessários, evitando improvisos e mudanças constantes.

A construção de espaços adequados para a oferta de educação, bem como de esporte e cultura, seja proporcional à população atendida em cada unidade.

As autoridades responsáveis pela gestão transformem a Escola num espaço de fato integrado às rotinas da unidade prisional e da execução penal, com a inclusão de suas atividades no plano de segurança adotado.

Seja realizado um diagnóstico da vida escolar dos apenados logo no seu ingresso ao sistema, com vistas a obter dados para a elaboração de uma proposta educacional que atenda às demandas e circunstâncias de cada um.

Seja garantido o atendimento diferenciado para presos (as) do regime fechado, semi-aberto, aberto, presos provisórios e em liberdade condicional e aqueles submetidos à medida de segurança independente de avaliação meritocrática.

O atendimento contemple a diversidade, atentando-se para as questões de inclusão, acessibilidade, gênero, etnia, credo, idade e outras correlatas.

Os responsáveis pela oferta elaborem estratégias para a garantia de continuidade de estudos para os egressos, articulando-as com entidades que atuam no apoio dos mesmos - tais como patronatos, conselhos e fundações de apoio ao egresso e organizações da sociedade civil.

A remição pela educação seja garantida como um direito, de forma paritária com a remição concedida ao trabalho e cumulativa quando envolver a realização paralela das duas atividades.

O trabalho prisional seja tomado como elemento de formação e não de exploração de mão-de-obra, garantida a sua oferta em horário e condições compatíveis com as da oferta de estudo.

Além de compatível, o trabalho prisional (e todas as demais atividades orientadas à de reintegração social 
nas Prisões) se torne efetivamente integrado à educação.

Seja garantida uma certificação não-estigmatizante para as atividades cursadas pelos educandos (sejam eles cursos regulares de ensino fundamental e médio, atividades não-formais, cursos profissionalizantes, etc.), de maneira a conciliar a legislação e o interesse dos envolvidos.

Exista uma política de incentivo ao livro e à leitura nas unidades, com implantação de bibliotecas e com programas que atendam não somente aos alunos matriculados, mas a todos os integrantes da comunidade prisional.

Seja elaborada uma cartilha incentivando os apenados à participação nos programas educacionais, bem como informações relativas a remição pelo estudo.

Os documentos e materiais produzidos pelos Ministérios da Educação e da Justiça e/ou pelas Secretarias de Estado de Educação e de Justiça ou Administração Penitenciária, que possam interessar aos educadores e educandos do Sistema, sejam disponibilizados e socializados, visando ao estreitamento da relação entre os níveis de execução e de gestão da Educação nas Prisões.

Sejam promovidos encontros regionais e nacionais sobre a Educação nas Prisões envolvendo todos os atores relevantes, em especial Diretores de Unidades Prisionais e do Setor de Ensino, tendo como um dos itens de pauta a troca de experiências.

Formação e Valorização dos Profissionais Envolvidos na Oferta do ensino prisional.

As propostas enquadradas neste eixo destinam-se a contribuir para a qualidade da formação e para as boas condições de trabalho de gestores, educadores, agentes penitenciários e operadores a execução penal.

Ao ingressar no cotidiano do sistema prisional, o professor passe por um processo de formação, promovido pela Pasta responsável pela Administração Penitenciária em parceria com a da Educação, no qual a Educação nas Prisões seja tematizada segundo os marcos da política penitenciária nacional.

A formação continuada dos profissionais que atuam no sistema penitenciário ocorra de maneira integrada, envolvendo diferentes áreas, como trabalho, saúde, educação, esportes, cultura, segurança, assistência psicossocial e demais áreas de interesse, de modo a contribuir para a melhor compreensão do tratamento penal e aprimoramento das diferentes funções de cada segmento.

No âmbito de seus projetos político-pedagógicos, as escolas de formação de profissionais penitenciários atuem de forma integrada e coordenada para formação continuada de todos os profissionais envolvidos e aprimoramento nas condições de oferta da educação no sistema penitenciário. Nos estados em que elas não existem sejam implementadas.

As Instituições de Ensino Superior e os Centros de Pesquisa sejam considerados parceiros potenciais no processo de formação dos profissionais do sistema, na execução de projetos de formação e na organização e disponibilização de acervos bibliográficos.

A formação dos servidores penitenciários contemple na sua proposta pedagógica a dimensão educativa do 
trabalho desses profissionais na relação com o preso.

Os atores estaduais estimulem a criação de espaços de debate, formação, reflexão e discussão como fóruns e redes que reflitam sobre o papel da educação nas prisões.

Os cursos superiores de graduação em Pedagogia e as demais Licenciaturas incluam nos seus currículos a formação para a EJA e, nela, a Educação Prisional.

Os educandos e educadores recebam apoio de profissionais técnicos (psicólogos, terapeutas, fonoaudiólogos, etc.) para o constante aprimoramento da relação de ensino-aprendizagem.

A pessoa presa, com perfil e formação adequados, possa atuar como monitor no processo educativo, recebendo formação continuada condizente com suas práticas pedagógicas, com direito à remição e remuneração.

Educação nas Prisões, com base nos fundamentos conceituais e legais da Educação de Jovens e Adultos, bem como os paradigmas da Educação Popular, calcada nos princípios da autonomia e da emancipação dos sujeitos do processo educativo.

Um regimento escolar próprio para o atendimento nos estabelecimentos de ensino do sistema prisional venha a ser criado, no intuito de preservar a unidade filosófica, político-pedagógico estrutural e funcional das práticas de Educação nas Prisões.

Cada Estado elabore os seus projetos pedagógicos próprios para a Educação nas Prisões, contemplando as diferentes dimensões da educação (escolarização, cultura, esporte, e formação profissional) e considerando a realidade do sistema prisional para a proposição das metodologias.

Seja estimulada a produção de material didático específico para a educação no sistema penitenciário, para complementar os recursos de EJA disponibilizados pela gestão local.

Seja elaborado um currículo próprio para a Educação nas Prisões, que considere o tempo e o espaço dos sujeitos da EJA inseridos nesse contexto e que enfrente os desafios que ele propõe em termos da sua reintegração social.

Essa proposta curricular seja elaborada a partir de um Grupo de Trabalho que ouça os sujeitos do processo educativo nas prisões (educadores, educandos, gestores do sistema prisional, agentes penitenciários e pesquisadores de EJA e do sistema prisional).

A educação de jovens e adultos no sistema penitenciário inclua a formação para o mundo do trabalho, entendido como um lócus para a construção da autonomia do sujeito e de desenvolvimento de suas capacidades profissionais, intelectuais, físicas, culturais e sociais.

Os familiares dos presos e a comunidade em geral sejam estimulados, sempre que possível, a acompanhar e participar de atividades educacionais que contribuam para o processo de reintegração social.

Sejam ampliadas as possibilidades de educação à distância em seus diferentes níveis, resguardando-se 
deste atendimento, o Ensino Fundamental.

Sejam ampliadas as possibilidades de uso de tecnologias nas salas de aula de unidades prisionais, visando ao enriquecimento da relação de ensino-aprendizagem.

Seja garantida a autonomia do professor na avaliação do aluno em todo o processo de ensino aprendizagem.

A articulação do Ministério da Justiça com os Ministérios da Educação, do Esporte, da Saúde e do Trabalho na perspectiva de que a educação prisional possa ocupar espaço prioritário na agenda governamental;

Aproximação entre DEPEN/MJ e SECAD/MEC para otimização de esforços e implementação de ações integradas no campo da educação prisional.

Política de Governo: política de segurança pública integrada a políticas sociais.

Ações em favor da aprovação da remição de pena pela educação (projetos de lei que modificam a Lei de Execução Penal estão em tramitação no Congresso Nacional).

Articulação internacional com a UNESCO que incentivou o Projeto Educando para Liberdade.

A nível de MERCOSUL colocação do tema da Educação Prisional com mais força nas pautas nacionais, integração entre as áreas - Justiça, Saúde, Educação - acesso a novas concepções de educação prisional e alternativas para lidar com a criminalidade e o papel da educação na ressocialização das pessoas apenadas, impulsionar políticas públicas integrais e integradas que favoreçam a educação em contextos de privação de liberdade, concebida como um direito ao longo de toda a vida, trocar experiências e informações, fomentar pesquisas e a cooperação técnica entre os países membros.

A educação é uma condição mínima de reintegração. Dados da Fundação de Amparo ao Trabalhador Preso (Funap) do Distrito Federal, segundo a qual o índice de reincidência de crimes dos egressos caiu de $70 \%$ para $30 \%$, com o trabalho de ressocialização por meio do ensino.

De acordo com a tese de mestrado do cientista social, Política Pública de Educação Penitenciária: contribuição para o diagnóstico da experiência do Rio de Janeiro do professor e ex-funcionário da secretaria de administração penitenciária (Saep) do Estado do Rio de Janeiro, Elionaldo Fernandes Julião de 2003 e dados atualizados em 2007. O objetivo do estudo era demonstrar de que forma o trabalho e a educação influem na reinserção social do preso e, conseqüentemente, nas chances que terá de reincidência no crime. Trabalhar na prisão diminui as chances de reincidência em 48\%. Quando o preso estuda na cadeia, as chances de voltar ao crime diminuem em $39 \%$.

"Em linhas gerais, através dos resultados deste estudo podemos afirmar que trabalho e estudo apresentam um papel significativo na reinserção social dos apenados, diminuindo consideravelmente a sua reincidência", aponta o cientista político.

Em estudo feito entre os presos do Rio de Janeiro com base na avaliação de 52 mil fichas de prisão 
realizada nos últimos cinco anos, o pesquisador chegou ao percentual de reincidência de $26 \%$ entre presos que não trabalharam, contra somente $11,2 \%$ dos que trabalharam e voltaram a cometer um crime.

$\mathrm{Na}$ área de educação, ainda no Rio de Janeiro, o pesquisador encontrou uma situação bastante parecida. O percentual de reincidência chega a $24,2 \%$ entre aqueles que não estudaram na prisão, ao passo que somente $6,3 \%$ dos que estudaram cometeram novos delitos.

A tese aponta que, em todo o país, apenas $17,3 \%$ de presos estudam na prisão participam de atividades educacionais de alfabetização, ensino fundamental, ensino médio e supletivo. "Não há dados mais precisos de quantos presos estão estudando em cada Estado".

Com relação à Unidade Prisional de Bom Jesus onde se realizou a pesquisa comprovou-se que o ensino é de qualidade e satisfaz aos detentos, embora se constate a necessidade de cada vez mais se adaptar o processo ensino-aprendizagem a realidade prisional do detento fazendo com que o ensino da escola aborde o seu contexto e a sua realidade.

O processo ensino-aprendizagem e a carga horária comparados com as demais escolas do EJA da Rede Estadual de Ensino de Bom Jesus e com as demais escolas das Penitenciárias do Estado do Piauí são satisfatórios e de qualidade contribuindo para recuperar os detentos para a vida após a prisão.

A carga horária deve ser cumprida rigorosamente para que todos os conteúdos programáticos possam ser ministrados ao longo dos semestres e ao final do ano letivo.

A educação é um processo não acabado que necessita constantemente ser aprimorado com novos métodos e técnicas que façam com que os detentos tomem gosto pelo estudo para que cada vez mais adquiram o conhecimento para transformar sua realidade e propiciar uma vida mais digna.

Reivindicar o aumento de agentes penitenciários para a Penitenciária Regional de Bom Jesus, requerer e sensibilizar a Secretaria da Justiça e de Direitos Humanos do Estado do Piauí para que dê posse e lote os agentes penitenciários que lograram êxito no último concurso e que já concluíram a academia e estão aptos para desempenharem as suas funções.

O número reduzido de agentes penitenciários impossibilita o aumento no número de detentos (reeducandos) que possam freqüentar a Escola da penitenciária devido à falta de segurança na Unidade Prisional.

Implantar e fazer funcionar a Escola Penitenciária Estadual em parceria com o Ministério da Justiça, através do Departamento Penitenciário Nacional para a formação e qualificação do servidor penitenciário.

Implantar outros Projetos de Humanização com os agentes penitenciários para que melhore o relacionamento deles com os detentos principalmente para fazer compreender a importância da educação na mudança do ser humano e como um dos meios para recuperação dos detentos.

Intensificar as parcerias com demais órgãos como a Empresa Brasileira de Pesquisa Agropecuária EMBRAPA que é parceiro e vizinho da Penitenciária em projetos e cursos de hortas, pesquisa e laboratórios para que os detentos possam freqüentar e aumentar os conhecimentos. 
Estabelecer parcerias com outros órgãos como a $14^{\mathrm{a}}$ Gerência Regional de Educação de Bom Jesus para instalar o Projeto TV ESCOLA, firmar parcerias com a Fundação Banco do Brasil e implantar o Programa BB Educar, Estação Digital, firmar parceria com o Escritório Regional de Bom Jesus do Instituto de Assistência Técnica e Extensão Rural do Piauí - EMATER/PI, Campus da Universidade Federal do Piauí em Bom Jesus e com o Campus da Universidade Estadual do Piauí em Bom Jesus.

Realizar palestras, seminários para trazer mais conhecimentos sobres diversos assuntos e atualizar os detentos que freqüentam a escola sobre os fatos e temas atuais.

Incentivar e apoiar a prática do artesanato como fonte de renda e de ocupação do tempo, plantio adequado e com técnica de hortas e outras atividades que possam ocupar o tempo e a mão de obra dos detentos.

Incentivar a prática desportiva e de outras atividades de lazer e de interação.

Firmar parcerias com a sociedade para doações de materiais para a prática do artesanato e a venda no comércio do artesanato que é produzido.

Solicitar junto a Secretaria Estadual de Educação e Cultura o aumento dos materiais didáticos, livros para a Escola da Penitenciária.

Capacitar os professores para que as disciplinas ministradas sejam voltadas para a realidade dos detentos.

Fiscalizar de forma mais efetiva os agentes penitenciários para que cumpram os horários de funcionamento da escola afim de que a carga horária seja efetivamente cumprida e para que os conteúdos programáticos possam ser ministrados ao longo do ano sem prejuízo para o processo ensinoaprendizagem.

Tentar melhorar o relacionamento e o convívio entre os agentes penitenciários, detentos e professores.

Realizar atividades recreativas e de interação com todos que fazem parte dos quadros da escola ou que estejam envolvidos direta ou indiretamente com a escola.A educação tem que ser de qualidade e buscar a cada dia melhorar os conteúdos, a forma de aprendizagem, um ensino voltado para a realidade da escola e dos detentos que a frequentam, estimulando ações concretas com as que foram citadas e que devem ser implementadas para melhorar o processo de formação e de aprendizagem dos detentos.

O estudo, a pesquisa e os resultados obtidos são relevantes cientificamente e contribuem para mudar e melhorar o processo ensino-aprendizagem da escola da penitenciária que se diga não se finda por aqui tal estudo devendo ser continuado porque como dissemos anteriormente a educação é processo que necessita constantemente ser aprimorado, melhorado e que não se esgota.

Deve-se investir na criação de uma escola para os sistemas penitenciários e socioeducativo cuja concepção educacional privilegie, acima de tudo, a busca pela formação de um cidadão consciente da sua realidade social. Também é essencial que o Ministério da Justiça e os órgãos competentes assumam a educação como uma das políticas de reinserção social e, em articulação com os Ministérios da Educação, da Saúde, da Cultura etc, definam as diretrizes nacionais para o "tratamento penitenciário e socioeducativo", visando à construção coletiva de uma política pública voltada à alfabetização e à 
elevação de escolaridade da população privada de liberdade e egressa no contexto das políticas de Educação de Jovens e Adultos.

Ciente de que sem a participação efetiva da sociedade as políticas públicas muitas vezes estão fadadas ao fracasso, acreditamos que somente avançaremos em uma política de execução penal e de medidas socioeducativas, que atenda os seus reais anseios, com a participação efetiva da sociedade civil organizada. Neste sentido, torna-se fundamental o estímulo à criação de Conselhos da Comunidade em todas as Varas de Execuções Penais, como já previsto na Lei de Execuções Penais e do fortalecimento dos Conselhos Estaduais e Municipais de Defesa dos Direitos das Crianças e dos Adolescentes, com o objetivo de acompanhar a execução das políticas em cada estado.

Sendo a Educação Formal, um dos meios de tornarem-se seres conscientes e melhores. Através da "educação orientada para o desenvolvimento de valores, atitudes, capacidades e competências que favoreçam a aprendizagem, a adaptabilidade e a relação com os outros". Os reclusos podem desenvolver atitudes positivas perante a sociedade em que estão inseridos, motivar-se relativamente aos "conhecimentos escolares" e encontrar o seu lugar na sociedade. É de suma importância a educação prisional, na medida em que é vista como instrumento de ressocialização, de desenvolvimento de habilidades e de educação para a empregabilidade. Os objetivos de encarceramento devem ultrapassar as questões de punição, isolamento e detenção. A educação formal tem demonstrado que auxilia na obtenção dos objetivos centrais de reabilitação e ressocialização, incidentes no resgate social, e minimização da discriminação social. Precisamos dentro da Educação Prisional, unir educação e trabalho para obtermos um crescimento qualitativo, e com as parcerias seremos referência no atendimento.

A relevância da educação prisional como instrumento de ressocialização e de desenvolvimento de habilidades e de educação para a empregabilidade é notória no sentido de auxiliar os reclusos a reconstruir um futuro melhor durante e após o cumprimento da sentença. Os objetivos de encarceramento ultrapassam as questões de punição, isolamento e detenção. A educação auxilia e permite a obtenção dos objetivos centrais de reabilitação que incidem em resgate social e educação libertadora numa dimensão de autonomia, sustentabilidade e minimização de discriminação social.

Trabalhar na busca da identidade perdida, e participar desta sociedade modernizada e midiatizada, poderá ser um viés articulador e um grande desafio para gerar mudanças, compromissos e possibilitar aos reeducandos um retorno digno à sociedade.

A educação é um direito de todos. A concepção e implementação de políticas públicas visando ao atendimento especial de segmentos da população estrutural e historicamente fragilizados, constituem um dos modos mais significativos pelos quais o Estado e a Sociedade podem renovar o compromisso para com a realização desse direito e a democratização de toda a sociedade. O espaço e o tempo do sistema penitenciário, aliás, confirmam esses pressupostos. Embora não faltem referências no plano interno e internacional, segundo as quais se devam colocar em marcha amplos programas de ensino, com a participação dos detentos, a fim de responder às suas necessidades e aspirações em matéria de educação.

\section{REFERÊNCIAS}

Adorno, Sérgio, (1991). A Prisão sob a ótica de seus protagonistas: Itinerário de uma Pesquisa. In: Tempo Social; Rev. de Sociologia da USP, São Paulo: 3(1-2):7-40 
Albornoz, Suzana, (2002). O que é trabalho. São Paulo: Brasiliense, Anistia Internacional. Brasil: “Aqui ninguém dorme sossegado" - violações dos direitos humanos contra detentos. São Paulo.

Aranha, M. L. A.de., (1998). História da educação. 2., São Paulo: Moderna.

Becker, Howard S., (1997). Métodos de Pesquisa em Ciências Sociais. São Paulo: Ed. Hucitec.

Brandão, Zaia (2002). Entre questionários e entrevistas. In: Pesquisa em Educação: conversas com pósgraduandos. Rio de Janeiro: Ed. PUC-Rio; São Paulo: Edições Loyola.

Brandão, D. M.S \& Crema, R. (1991). Visão Holística em Psicologia e educação. São Paulo: Summus.

Brasil, Constituição (1988) Constituição da República Federativa do Brasil. Atualizada até 31. 12. 1999. 5., São Paulo: TR, 2000 266p.

Brasil, Lei N 9.394, 20 dez. 1996. Diretrizes e Bases da Educação Nacional.

Buarque, C. 1993. Qualidade de vida: a modernização da utopia. Revista Lua Nova, São Paulo, n31, p. 157-165.

Capeller, Wanda. (1985). O Direito pelo avesso: análise do conceito de ressocialização.In: Temas IMESC, Soc. Dir. Saúde. São Paulo: 2(2):127-134.

Carvalho Filho, Luis Francisco. (2002). A Prisão. São Paulo: Publifolha.

Chauí, Marilena. (1980). O que é Ideologia. São Paulo: Brasiliense.

Código de Processo Penal. (1999). São Paulo: Editora Revista dos Tribunais.

Constituição da República Federativa do Brasil: (1995). promulgada em 5 de outubro de 1988. 26 Edição atualizada e ampliada. São Paulo: Saraiva, 2007.

Coulon, Alain. A Escola de Chicago. São Paulo: Papirus.

Cury, Carlos R. Jamil. (1985). Educação e contradição: elementos metodológicos para uma teoria crítica do fenômeno educativo. São Paulo: Cortez/ Autores Associados.

Catapan, A. H. Trabalho \& consumo: para além dos parâmetros curriculares. Florianópolis: Insular.

Conzatti. O. (1998). Educação para os valores. Philos, Revista Brasileira de Filosofia no $1^{\circ}$ Grau. Florianópolis, Ano 5, № 9, p. 46-50, $1^{\circ}$ semestre.

Delors, Jacques, (2000). et alii. Educação um tesouro a descobrir. 4., São Paulo: Demo, P. (1985). Sociologia uma introdução crítica. 2., São Paulo: Atlas.

Diário do Congresso Nacional, (1999). Suplemento ao n. 61, de 04/06/1976, p. 2, 
In: Exposições de Motivos da Lei de Execução Penal - Código de Processo Penal, São Paulo, p. 121.

Diretrizes para elaboração de projetos e construção de Unidades Penais no Brasil. Brasília: (1995). CNPCP.

Dowdney, Luke. (2003). Crianças do Tráfico: um estudo de caso de crianças em violência armada organizada no Rio de Janeiro. Rio de Janeiro: 7 letras.

Durkheim, Émile. (1978). Educação e Sociologia. São Paulo: Melhoramentos/ Fundação Nacional de Material Escolar, Rio de Janeiro.

Freire, P. (1983). Educação e mudança. 7., Rio de Janeiro: Paz e Terra.

A importância do ato de ler. (1983). 3.,São Paulo: Cortez.

A importância do ato de ler, (1994). em três artigos que se contemplam. 14.

São Paulo; Cortez.

Pedagogia do oprimido. (1987). 30., Rio de Janeiro: Paz e Terra.

Terra,

Pedagogia da Autonomia. (1997). Saberes necessários a prática educativa. São Paulo: Paz e

Freire, P. \& Rivière, P. (1987). O processo educativo segundo Paulo Freire e Pichon Rivière. São Paulo: Vozes.

Foucault, M. (1979). Microfísica do poder. Trad. de Roberto Machado. Rio de Janeiro: Graal.

Vigiar e punir: (1998). Nascimento da prisão. Trad. de Raquel Ramalhete. 18., Petrópolis: Vozes.

Florianópolis: Insular.

. História da Loucura. (2001). São Paulo: Editora Perspectiva. Ciências da cognição.

Gadotti, M. (1984). A educação contra a educação: o esquecimento da educação e a educação permanente. 3., Rio de Janeiro: Paz e Terra.

História das idéias pedagógicas. (1998). 6., São Paulo: Ática.

Gadotti, M.; Freire, P. \& Guimarâes, S. (1985). Pedagogia: diálogo e conflito. São Paulo: Cortez Autores Associados.

Gentili, Pablo \& Silva, Tomaz Tadeu da. (1994). Neoliberalismo, Qualidade Total e Educação: visões críticas. Petrópolis: Vozes.

Gentili, P. (1995). (org.) Pedagogia da exclusão. Crítica ao neoliberalismo em educação. 6., Rio de 
Janeiro: Vozes.

Geraldi, J. W. (1993). Portos de passagem. São Paulo: Martins Fontes.

Gramsci, Antonio. (1971). Selections from prison Notebooks. New York: International Publishers.

Grossi, E. (1997). Lei de Diretrizes e Bases da Educação. Lei n 9.394, de Dezembro de 1998. Rio de Janeiro: Pargos.

Goffman, Erving. (1961). Manicômios, Prisões e Conventos. São Paulo: Editora Perspectiva.

Gutierres, P.F.\& Castilho, D.P. (1994). A Meditação pedagógica: Educação a Distância alternativa. Campinas: Papirus.

Ibáñez, Enrique del Acebo \& BRIE, Roberto J. (2001). Diccionario de Sociología. Buenos Aires: Claridad.

Jesus, Antonio Tavares de. (1989). Educação e Hegemonia no pensamento de Antonio Gramsci, São Paulo: Cortez.

Kuenzer, Acácia Z. (2002)Pedagogia da Fábrica: as relações de produção e a educação do trabalhador. São Paulo: Cortez.

Lemgruber, Julita. Nem todo criminoso precisa ir para cadeia: a prisão só serve para quem ameaça a sociedade. In: Revista Super Interessante -Edição Especial: Segurança. São Paulo: Editora Abril, 04/2002, p. 60 e 61.

Manacorda, M. (1999). A História da educação: da antiguidade aos nossos dias. São Paulo: Cortez.

A vida nas escolas: (1997). uma introdução à pedagogia crítica nos fundamentos da educação. 2 ., Porto Alegre: ArTmed.

Educação a distância: (2001) - 02. Planejamento e gestão em educação a distância.

Curso de Formação em Educação a Distância- UNIREDE. Curitiba MEC/Seed:UFP.

Martins, Paulo de Sena. (2002). Assistência Educacional nos Estabelecimentos Penais.

Brasília: Câmara dos Deputados.

Mason, Robin. Models of Online Courses. ALN Magazine. Volume 2, Issue 2 - October 1998.

Maturana H.R. \& Varela, F. J. (1973). Autopoiésis - a organização da vida. Prefácio de Standford Beer.

Médicos / HC- FMUSP. Medicina e Violência. São Paulo: Ano II, nº 8, maio/junho de 1999. 
Minayo, M. A. C. S. (1999). Pesquisa social. Teoria, Método e criatividade. 12., Petrópolis: Vozes.

Ministério DA Educação, Conselho Nacional de Educação. Diretrizes Curriculares Nacionais para a Educação de Jovens e Adultos. 2006. Brasília.

Ministério DA Justiça, Secretaria Nacional de Justiça, Departamento Penitenciário Nacional - Brasil: Informações Penitenciárias. Brasília - Abril de 2006.

, Secretaria Nacional de Justiça, 2006. Departamento Penitenciário Nacional. Programa de Reestruturação do Sistema Penitenciário Nacional: Termo de Referência para elaboração de projetos destinados à melhoria do Sistema Penitenciário Nacional. Brasília.

Diretrizes Básicas de Política Criminal e Penitenciária.

Brasília: (2005) Offe, Claus. Sistema educacional, sistema ocupacional e política da educação contribuição à determinação das funções sociais do sistema educacional. In: Revista Educação \& Sociedade, $\mathrm{n}^{\circ} 35$, abril de 1990.

Mirabete, J. F. (1993). Lei de execução penal. 5., São Paulo: Atlas.

Moore, Michael G. (1996). Distance education: a systems view / Title: - United States.

Moran, J. M. (2000). Novas Tecnologias e Mediação Pedagógica. São Paulo: Papirus.

Morin, E. (2000). Os sete saberes necessários a educação do futuro. São Paulo: Cortez.

Neves, C.M.C. TV na Escola e os desafios de hoje: Tecnologias e educação: desafios e a TV escola. 2000. Módulo 1, Brasília; EAD/SEED.

Oliveira, Edmundo. O Futuro Alternativo das Prisões. Rio de Janeiro, Forense, 2001.

Oliveira, O.M.de.(1996). Prisão: um paradoxo social. 2., Florianópolis: DAUSFC,

Piletti, C. \& Piletti, N.(1988). Filosofia e história da educação. São Paulo: Ática.

Didática geral. 23. (2001), São Paulo: Ática.

Piletti, N. (1997). Psicologia Educacional. 15.,São Paulo: Ática.

Pimentel, N.M. (2000). (org) Gestão Escolar: Programa de qualificação de educadores. Florianópolis, LED/UFSC.

Pinker, S. (1999) (Motta, L.T: Tradução). Como a mente funciona. São Paulo: Companhia das Letras.

Possenti, S. (1998). Por que (não) ensinar gramática na escola. 3., Campinas: Mercadon de Letras. 
Regras Mínimas para o Tratamento do Preso no Brasil. Brasília: (1995). Conselho Nacional de Política Criminal e Penitenciária.

Severino, Antônio Joaquim. (1983). A Cidadania como inclusão social: tarefa da educação. In: Revista da APG - PUC/SP. São Paulo: (2000), ano IX, nº 21

Simmel, George. Sociologia. São Paulo: Ática.

Tavares dos santos, José Vicente. (1978). Colonos do vinho: estudo sobre a subordinação do trabalho camponês ao capital. São Paulo: Hucitex, , p. 3.

Thompson, Augusto. (1980). A questão da penitenciária. $2^{a}$ ed. Rio de Janeiro: Forense.

Tfouni, L.V. (1995). Letramento e alfabetização. São Paulo: Cortez.

O resgate da identidade: (1986). investigação sobre o uso da modalidade por adultos não alfabetizados. Cadernos de estudos linguísticos.

Thiollent, M. (1998). Metodologia da pesquisa-ação. 8., São Paulo: Cortez.

Toffler, A. (1998). A terceira onda. 23., Rio de Janeiro: Record.

Thomal, A.(1998). O processo da educação para a cidadania. Philos, Revista Brasileira de Filosofia no $1^{\circ}$ Grau. Florianópolis, Ano 5, No 9, p. $72-791^{\circ}$ semestre.

Triviños, A,N.S. (1987). Introdução a pesquisa científica social. A pesquisa qualitativa em educação. O positivismo. A fenomenologia. O Marxismo. São Paulo: Atlas,

Valdejão, Renata. Prisões: lotadas e falidas, as cadeias brasileiras não isolam nem recuperam os criminosos. Para salvá-las, é preciso devolver a dignidade aos presos.

In: Revista Super Interessante -Edição Especial: Segurança. São Paulo: Editora Abril, 04/2002, p. 51 a 53.

Vasconcellos, C. S. (1999). Construção do conhecimento em sala de aula. $8^{\text {a }}$ „,São Paulo: Libertad.

Varella, Drauzio. (1999). Estação Carandiru. São Paulo: Companhia das Letras.

Velho, Otávio Guilherme. (1979). O Fenômeno Urbano. Rio de Janeiro: Zahar Editores.

Vianney, J. (cord.) et alii. (1998). Introdução em Educação A Distância. Universidade Federal de Santa Catarina. Florianópolis: Laboratório de Ensino a Distância.

Young, Pauline V. (1960). Métodos científicos de investigacion social. 2a ed. México: Universidade Nacional Autônoma. 
Vygotsky, L.S. (1989). Pensamento e linguagem. Sã Paulo: Martins Fontes.

Wacquant, Loïc. (2001). As Prisões da Miséria. Rio de Janeiro: Jorge Zahar.

Os Condenados da Cidade: (2001). estudo sobre marginalidade avançada. Rio de Janeiro: Editora Revan; FASE.

Punir os Pobres: (2001). a nova gestão da miséria nos Estados Unidos. Rio de Janeiro: Instituto Carioca de Criminologia; Editora Freitas Bastos,

Weber, Max. (1974). Sobre la teoria de lãs ciências sociales. Barcelona: Península.

A objetividade do conhecimento na Ciência Social e na Ciência

Política - 1904. 1993. In: Métodos das Ciências Sociais - Parte 1. São Paulo: Cortez; Campinas: Editora Unicamp.

Winner, L. 1987. La ballena y el reactor. Espanha: Gedisa, Barcelo,

http://www.comunidadesegura.org/?q=pt/node/35374/

http://www.comunidadesegura.org/?q=pt/node/35379

http://portaldaclube.globo.com/noticia.php?hash=9feba13263ac6b6a68a08f5e7123bc40\&id=185

03/04/2006 14:56 por Tom Lima.

E:ITextos mestradolDireitos Humanos no Brasil a exclusão dos detentos.htm

http://www.sepe.pi.gov.br/materia.php?id=18351

http://www.secjus.pi.gov.br/

http://www.advogado.adv.br/artigos/2003/romualdoflaviodropa/

direitoshumanosdetentos.htm

http://www.controlesocial.org.br/boletim/ebul19/tem_verde.html

http://www.mj.gov.br/depen/data/Pages/

MJDA8C1EA2ITEMID0A92E04549BC444EBF4358C793E9539APTBRIE.htm

http://veja.abril.com.br/250209/p_084.shtml

http://www.brasildefato.com.br/v01/agencia/nacional/relatorio-discute-o-direito-a-educacao-nos-presidios http://www.ilanud.org.br/comunicacao/noticias/relator-da-onu-divulga-informe-sobre-educacao-nasprisoes/ 
www2.dbd.puc-rio.br/pergamum/.../0114322_03_pretextual.pdf

\section{ANEXOS}

\section{Anexo 01.}

Ofício solicitando permissão e acesso a Penitenciária Regional Dom Abel Alonso Núñez.

Bom Jesus (PI), 06 de agosto de 2007.

Ao Ilmo. Sr.

\section{Bel. RAIMUNDO CARLOS NOGUEIRA ALMEIDA}

MD. Gerente da Penitenciária Regional Dom Abel Alonso Núñez

$\mathrm{Br}-135, \mathrm{Km} 3,7$, Localidade Vila Estela

Bom Jesus - Piauí.

Assunto: Solicitação de permissão para acesso a Penitenciária Regional Dom Abel Alonso Núñez.

\section{Anexo 02.}

Questionário apresentado e dirigido ao Gerente da Unidade Prisional de Bom Jesus, Estado do Piauí, Brasil.

Questionário apresentado e dirigido ao Gerente da Unidade Prisional de Bom Jesus, Estado do Piauí, Brasil, a quem desde já agradecemos pelas respostas e pronto atendimento nas solicitações para a realização da presente avaliação institucional da Escola da Penitenciária:

Gerente da Unidade Prisional: Bel. RAIMUNDO CARLOS NOGUEIRA ALMEIDA

Data da aplicação do questionário: 08/10/2007

1) De quem partiu a iniciativa da implementação do projeto de educação do preso nesta Instituição?

2) A sociedade participa da reeducação do preso?

3) Os detentos são classificados segundo seus antecedentes para que possam frequentar a Escola da Penitenciária?

$\operatorname{Sim}($ ) Não( )

4) Quantidade de detentos que frequentam o módulo de ensino:

5) Grau de escolaridade: 
Ensino Fundamental incompleto:

Ensino Fundamental completo:

Ensino Médio incompleto:

Ensino Médio completo:

Curso superior em andamento:

Curso superior completo:

6) O ensino ministrado na Escola da Penitenciária Regional de Bom Jesus é de boa qualidade com relação as demais escolas da rede estadual de ensino e demais penitenciárias?

$\operatorname{Sim}($ ) Não( )

7) O processo ensino-aprendizagem é voltado para a realidade do detento?

$\operatorname{Sim}($ ) Não( )

8) O que pode ser feito de concreto para melhorar o processo ensino-aprendizagem?

9) A carga horária é suficiente para que sejam ministrados todos os conteúdos durante o ano?

$\operatorname{Sim}($ ) Não( )

10) A escola tem contribuído como um dos instrumentos de recuperação dos detentos?

$\operatorname{Sim}($ ) Não( )

11) Os detentos que frequentam a escola da Penitenciária tem melhor comportamento carcerário do que os que não frequentam?

$\operatorname{Sim}($ ) Não( ）

12) $\mathrm{O}$ que pode ser melhorando ou modificado para que o processo ensino-aprendizagem e a carga horária atendam seus objetivos?

13) O que pode ser feito para aumentar o número de vagas para os detentos na Escola da Penitenciária?

\section{Anexo 03.}

Questionário apresentado e dirigido aos detentos (reeducandos) que frequentam a Escola da Penitenciária Regional de Bom Jesus, Estado do Piauí, Brasil.

Questionário apresentado e dirigido aos detentos (reeducandos) que frequentam a Escola da Penitenciária Regional de Bom Jesus, Estado do Piauí, Brasil, a quem agradecemos pela disposição de responder os questionamentos e o tratamento cordial:

Data da aplicação do questionário: 08/10/2007 
1) Nome:

2) Idade:

3) Grau de escolaridade:

4) Delito cometido:

5) Há quanto tempo está preso?

6) Qual a pena a ser cumprida?

7) Quais são as suas esperanças depois de concedida a liberdade?

8) O ensino ministrado na Escola da Penitenciária Regional de Bom Jesus é de boa qualidade com relação as demais escolas?Sim( ) Não( )

9) O processo ensino-aprendizagem é voltado para a realidade do detento?

Sim( ) Não( )

10) O que pode ser feito de concreto para melhorar o processo ensino-aprendizagem?

11) A carga horária é suficiente para que sejam ministrados todos os conteúdos durante o ano?

$\operatorname{Sim}($ ) Não( )

12) O que pode ser melhorando ou modificado para que o processo ensino-aprendizagem e a carga horária atendam seus objetivos?

13) O que pode ser feito para aumentar o número de vagas para os detentos na Escola da Penitenciária?

\section{Anexo 04.}

Questionário apresentado e dirigido aos professores que ministram aulas na Escola da Penitenciária Regional de Bom Jesus, Estado do Piauí, Brasil, a quem desde já agradecemos por atender a solicitação e o empenho em discutir e responder os questionamentos:

Data da aplicação do questionário: 08/10/2007

\section{Professores:}

1) O ensino ministrado na Escola da Penitenciária Regional de Bom Jesus é de boa qualidade com relação as demais escolas da rede estadual de ensino da cidade de Bom Jesus e escolas das demais penitenciárias? $\operatorname{Sim}($ ) Não( )

2) O processo ensino-aprendizagem da escola é voltado para a realidade do detento?

$\operatorname{Sim}($ ) Não( ) 
3) O que pode ser feito de concreto para melhorar o processo ensino-aprendizagem?

$\mathrm{R}-$

4) A carga horária é suficiente para que sejam ministrados todos os conteúdos durante o ano?

Sim( ) Não( )

5) A escola tem contribuído como um dos instrumentos de recuperação dos detentos?

$\operatorname{Sim}($ ) Não( )

6) O sistema oferece ao professor condições de trabalho voltado para a realidade do detento?

$\operatorname{Sim}($ ) Não( )

7) O que poderia ser modificado no Sistema Penitenciário na área de ensino e aprendizagem, para melhor aproveitamento do detento?

$\mathrm{R}-$.

8) O material disponível é suficiente para o desenvolvimento das atividades de ensino?

$\operatorname{Sim}($ ) Não( )

9) Em caso negativo o que é necessário?

$\mathrm{R}-$

10) O número de horas-aula é suficiente para a aprendizagem do detento?

$\operatorname{Sim}($ ) Não( )

11) O que pode ser melhorando ou modificado para que o processo ensino-aprendizagem e a carga horária atendam seus objetivos?

$\mathrm{R}-$

12) O que pode ser feito para aumentar o número de vagas para os detentos na Escola da Penitenciária? $\mathrm{R}$ -

Anexo 05 - Fotografias 


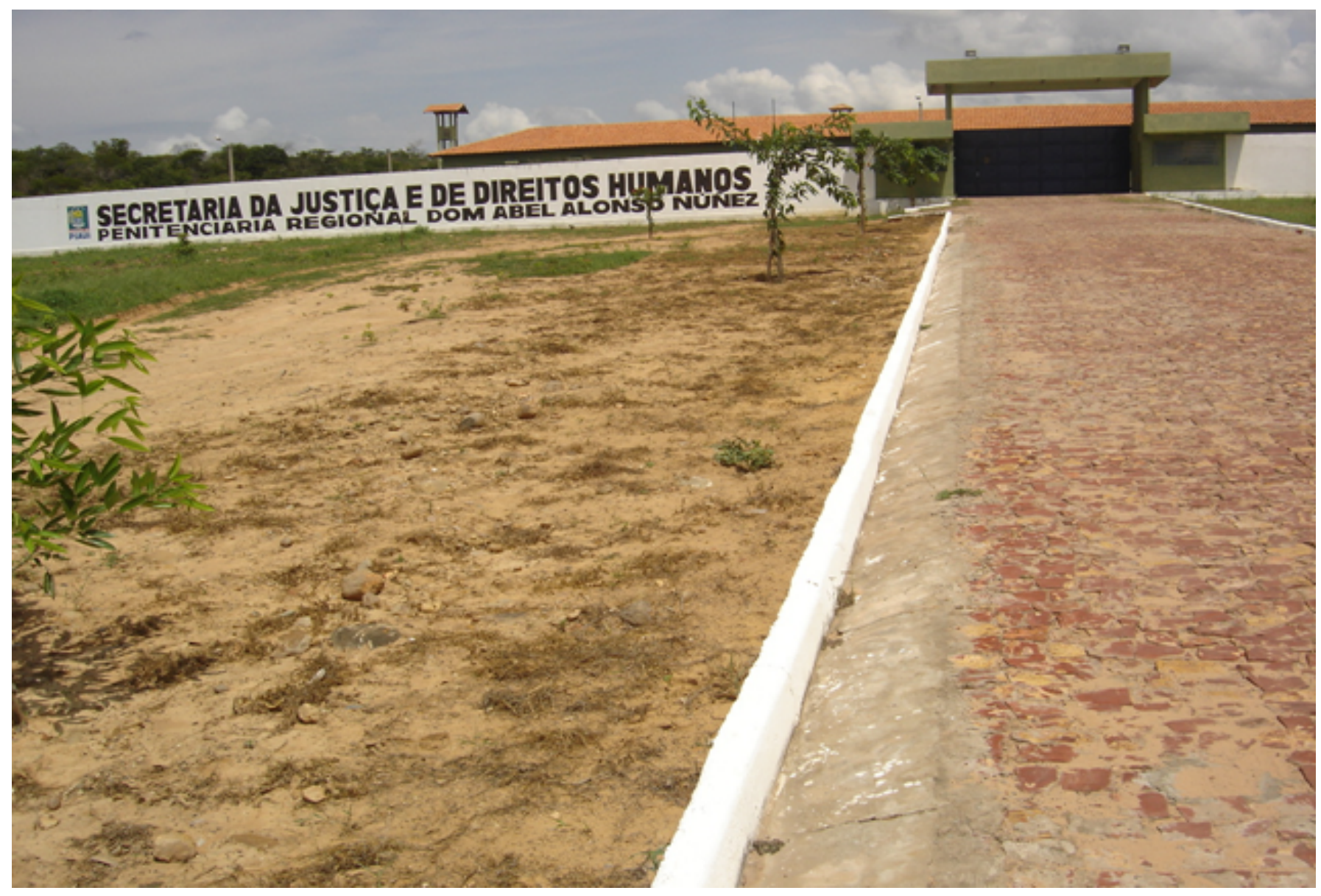

Figura 3 - ENTRADA DA PENITENCIÁRIA REGIONAL DE BOM JESUS, PIAUÍ, BRASIL. 
Revista Científica Multidisciplinar Núcleo do Conhecimento - RC: 9757 - ISSN: 2448-0959

https://www.nucleodoconhecimento.com.br/lei/prisional-no-mercosul

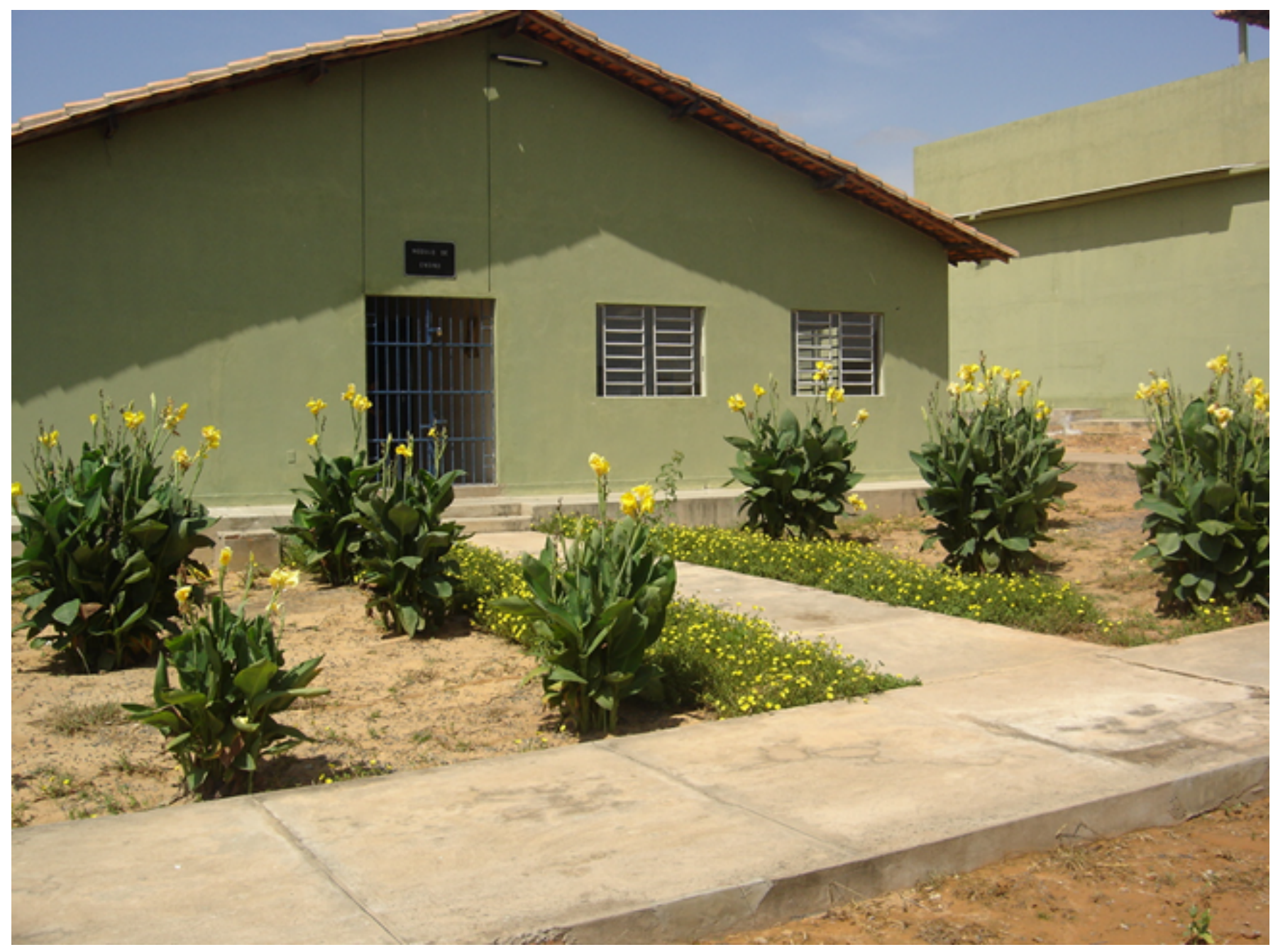

Figura 4 - VISÃO DA ENTRADA DA ESCOLA DA PENITENCIÁRIA 


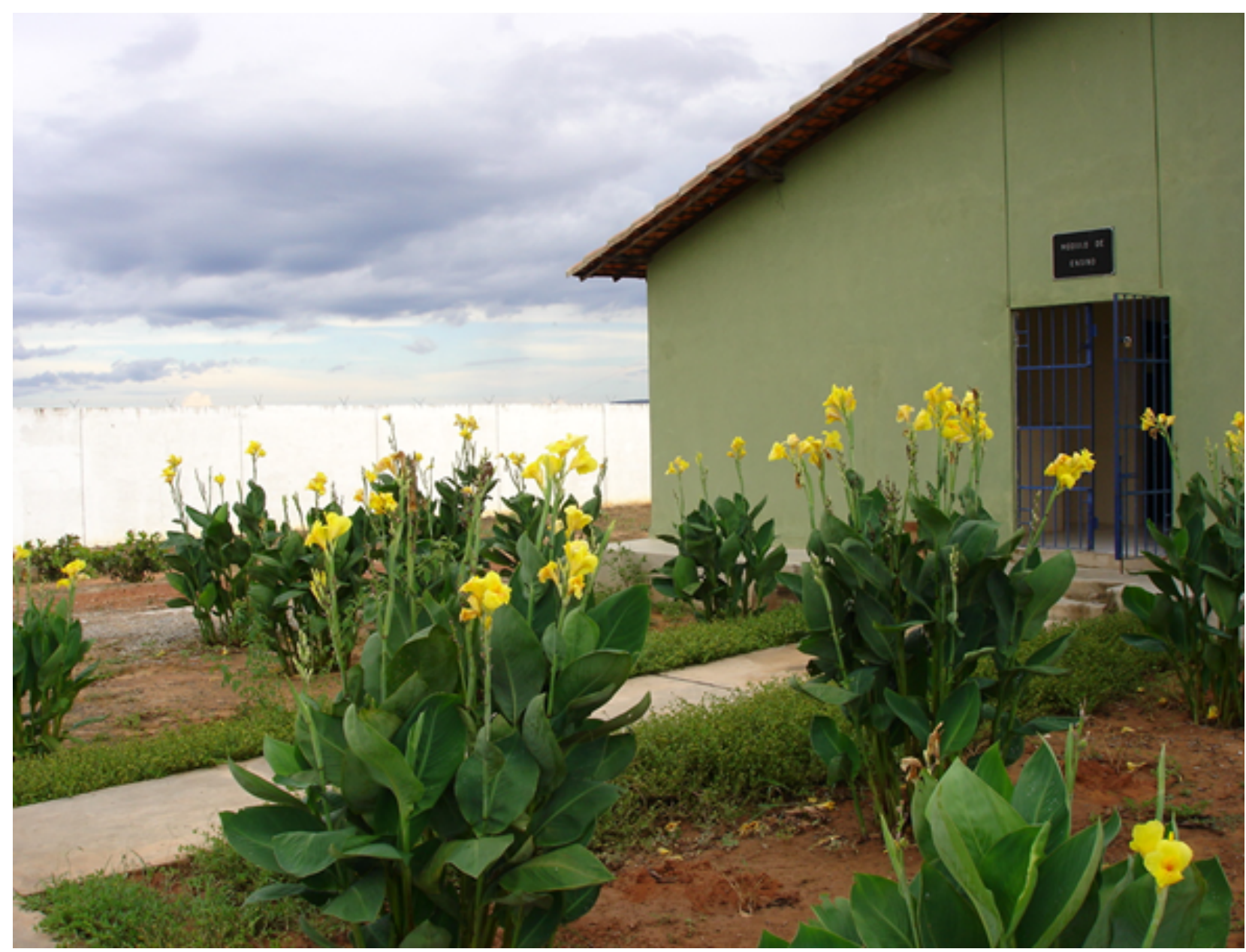

Figura

5 - JARDIM DA ESCOLA UM DOS TRABALHOS DOS REEDUCANDOS DA ESCOLA 


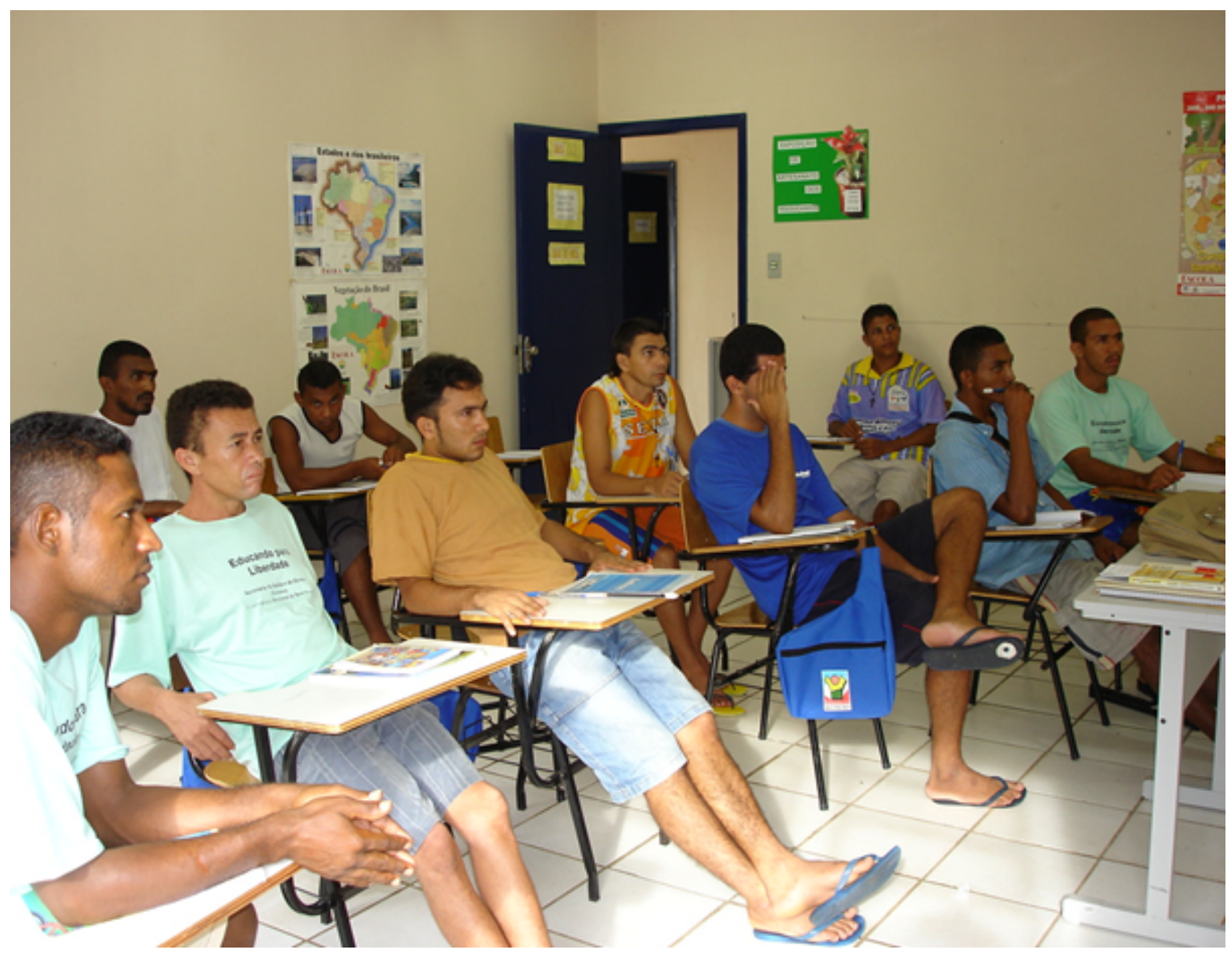

Figura 6 - REEDUCANDOS EM SALA DE AULA 


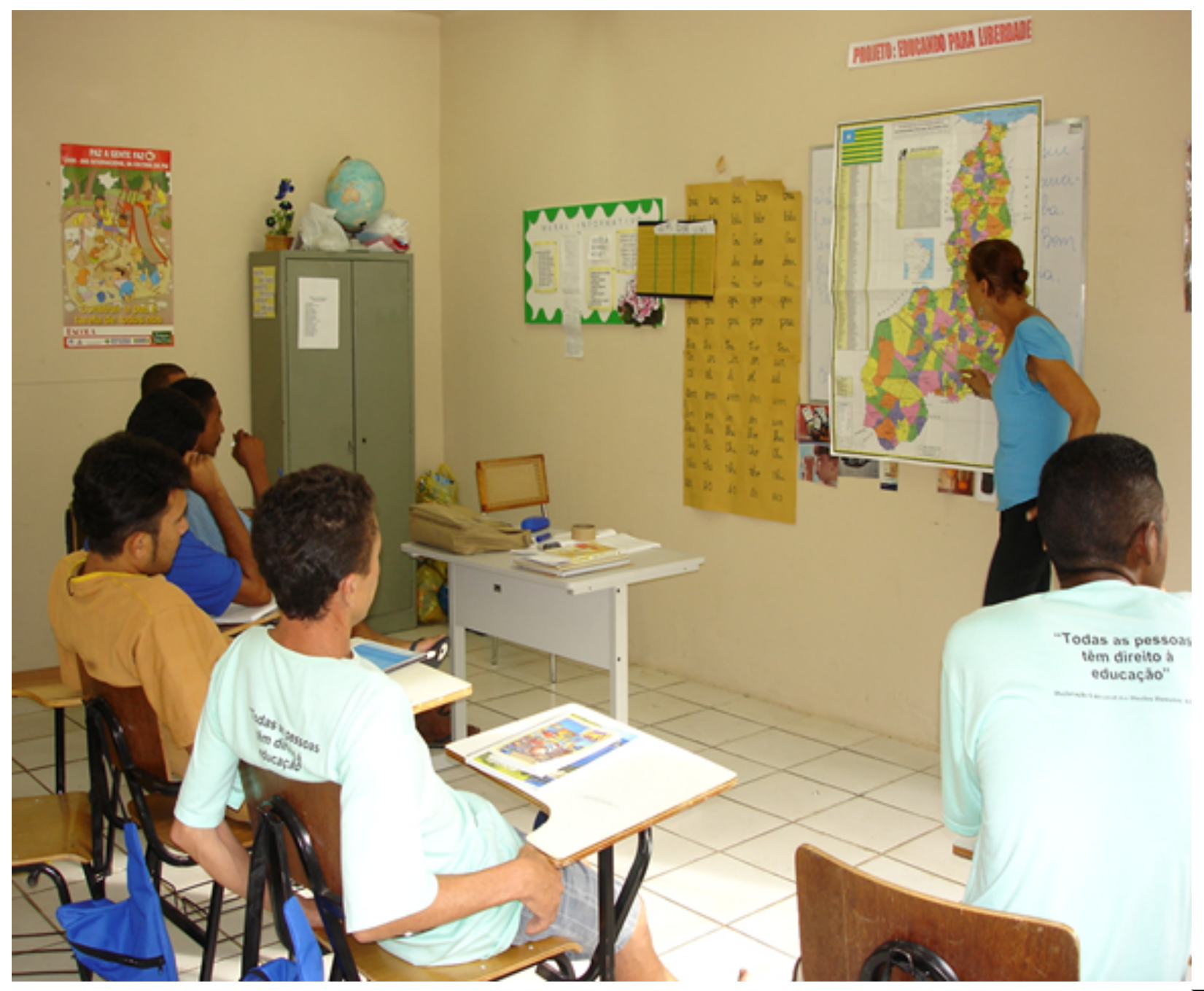

- PROFESSORA MINISTRANDO AULA DE GEOGRAFIA

Figura 7 


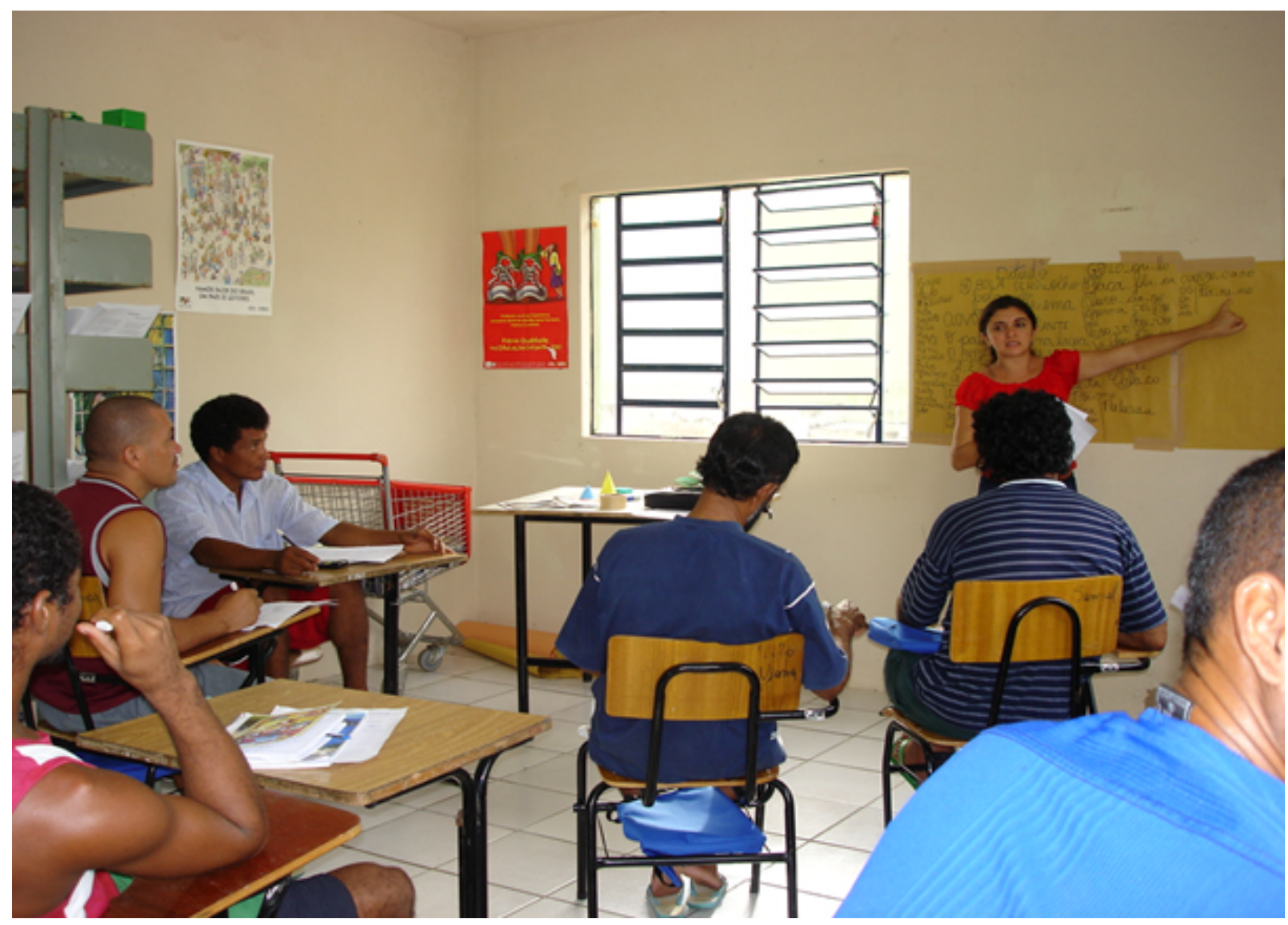

Figura 8 - PROFESSORA MINISTRANDO AULA DE PORTUGUÊS 
Revista Científica Multidisciplinar Núcleo do Conhecimento - RC: 9757 - ISSN: 2448-0959

https://www.nucleodoconhecimento.com.br/lei/prisional-no-mercosul

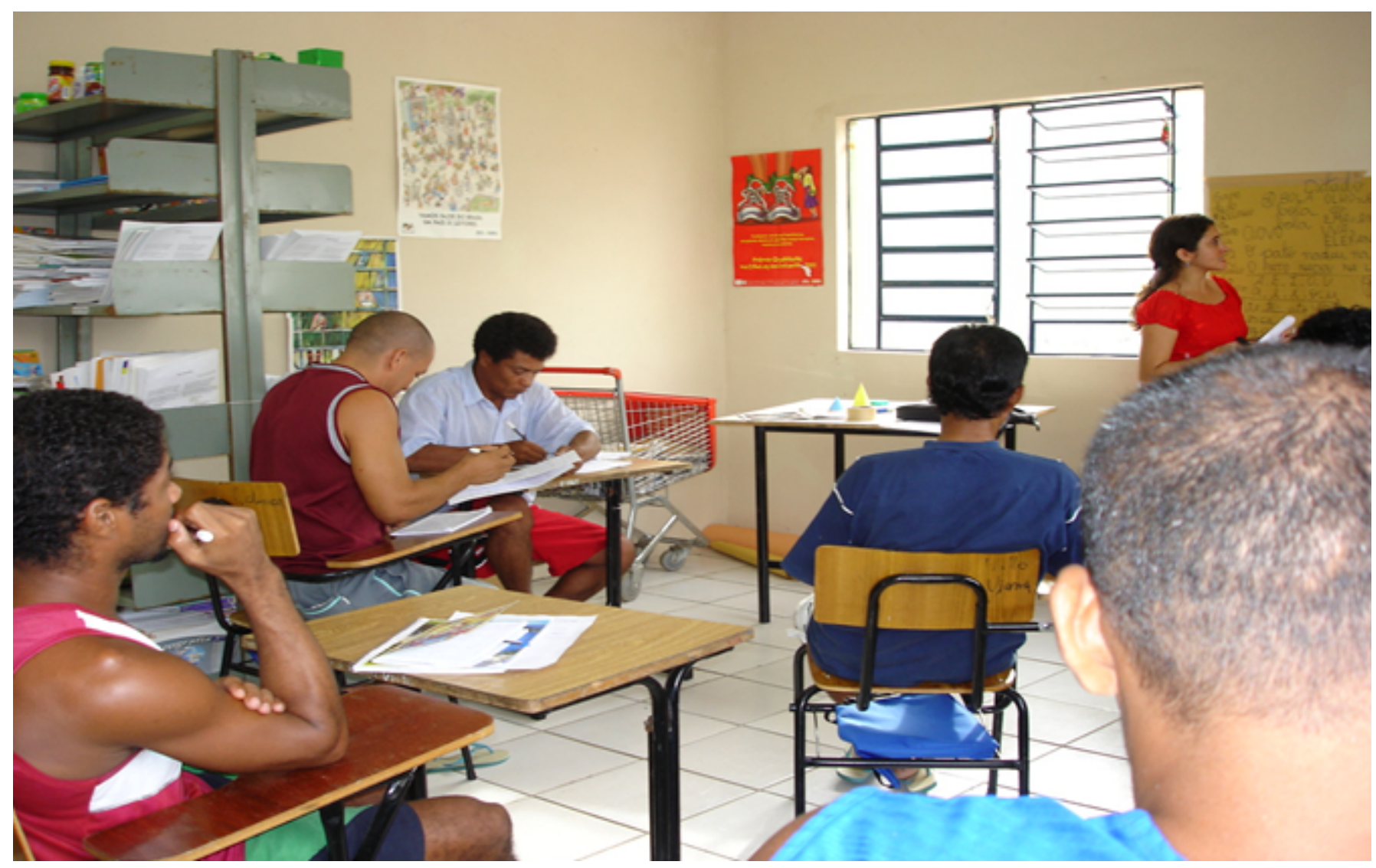

Figura 9 - REEDUCANDOS CORRIGINDO TAREFAS EM SALA DE AULA 
Revista Científica Multidisciplinar Núcleo do Conhecimento - RC: 9757 - ISSN: 2448-0959

https://www.nucleodoconhecimento.com.br/lei/prisional-no-mercosul

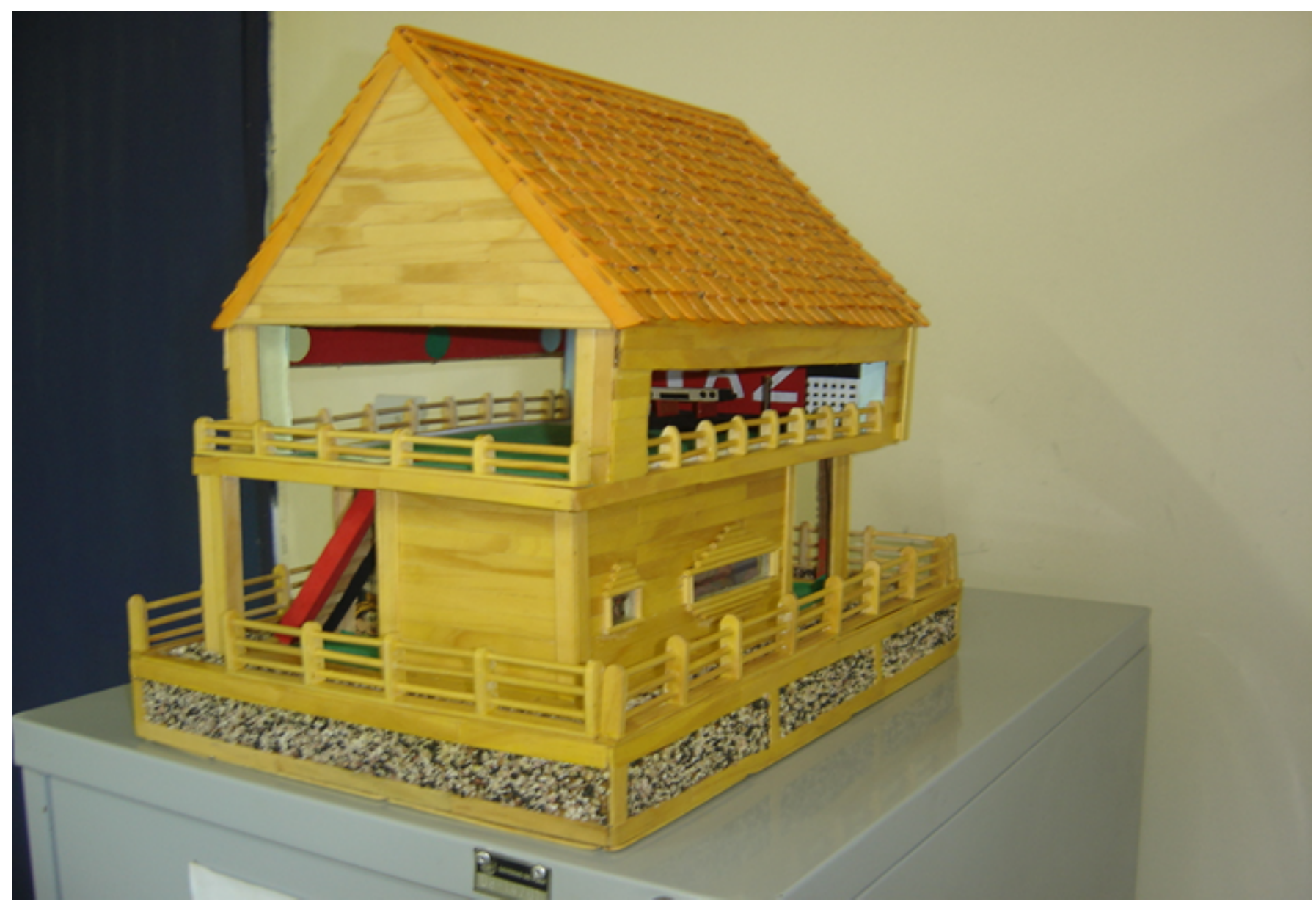

Figura 10 - ARTESANATO PRODUZIDO POR DETENTO QUE FREQUENTA A ESCOLA DA PENITENCIÁRIA 
Revista Científica Multidisciplinar Núcleo do Conhecimento - RC: 9757 - ISSN: 2448-0959

https://www.nucleodoconhecimento.com.br/lei/prisional-no-mercosul

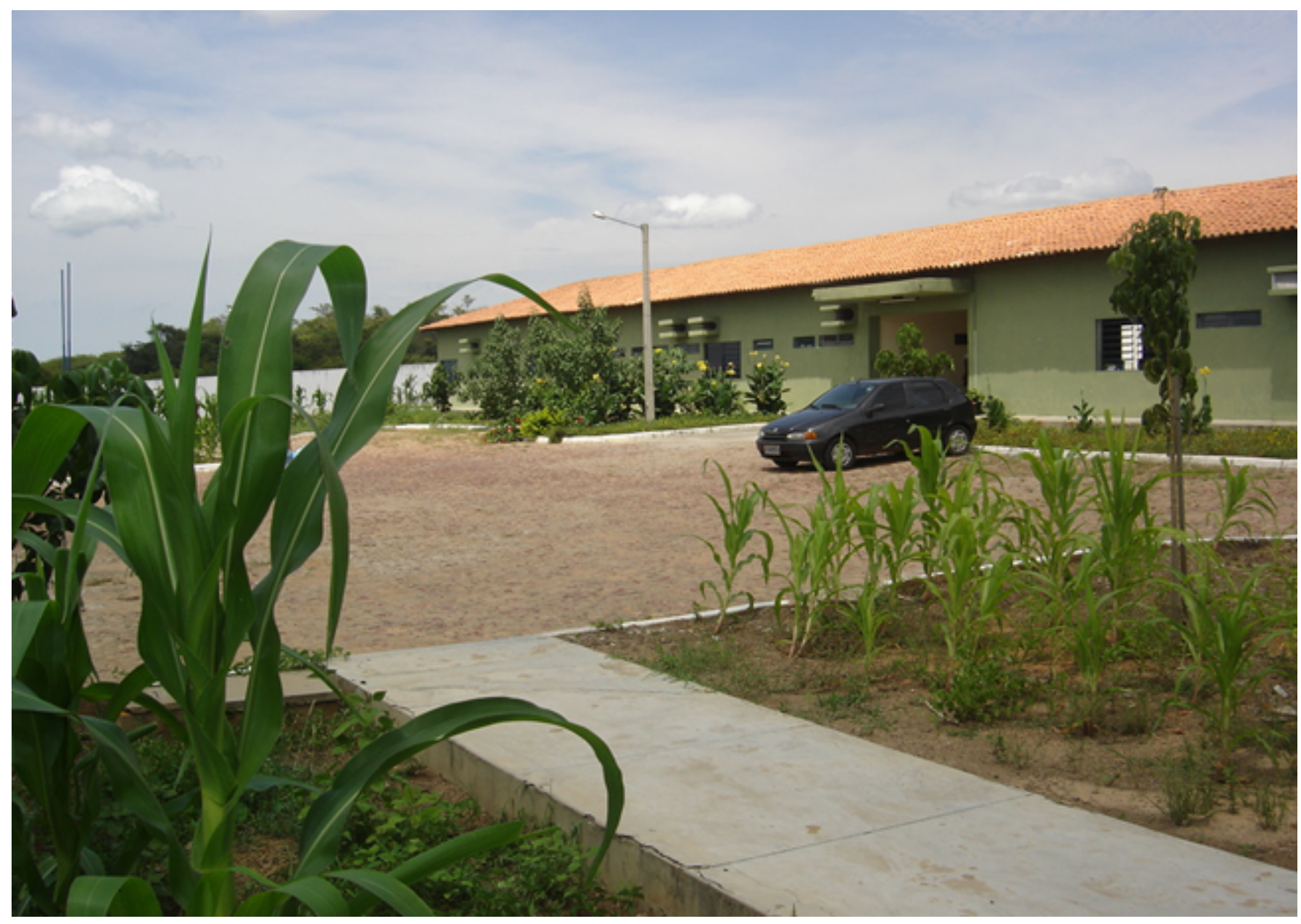

Figura 11 - JARDINS DO PRÉDIO DA ADMINISTRAÇÃO DA PENITENCIÁRIA CONSTRUÍDOS PELOS REEDUCANDOS 
Revista Científica Multidisciplinar Núcleo do Conhecimento - RC: 9757 - ISSN: 2448-0959

https://www.nucleodoconhecimento.com.br/lei/prisional-no-mercosul

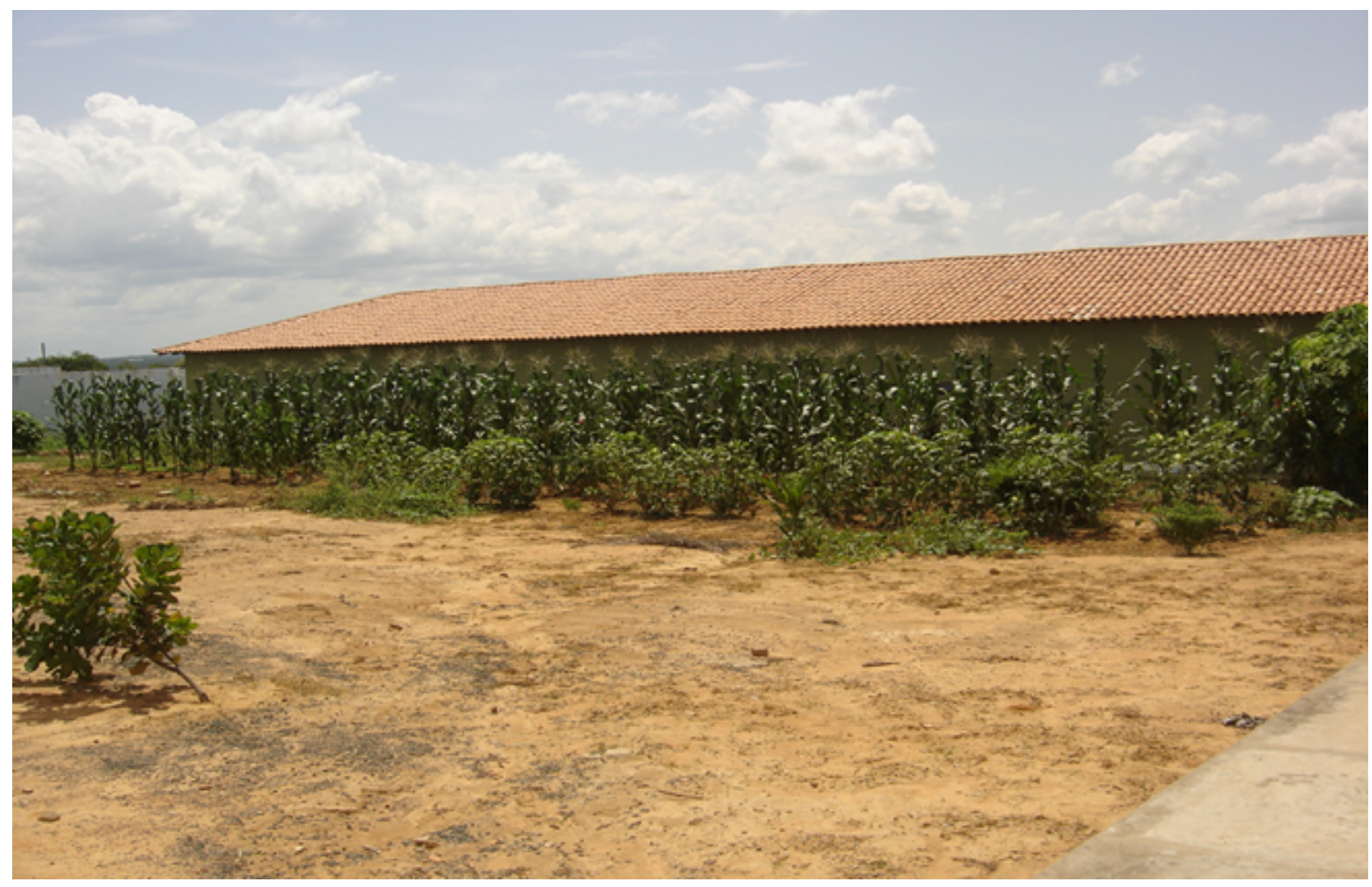

Figura 12 - PLANTAÇÕES REALIZADAS PELOS REEDUCANDOS 


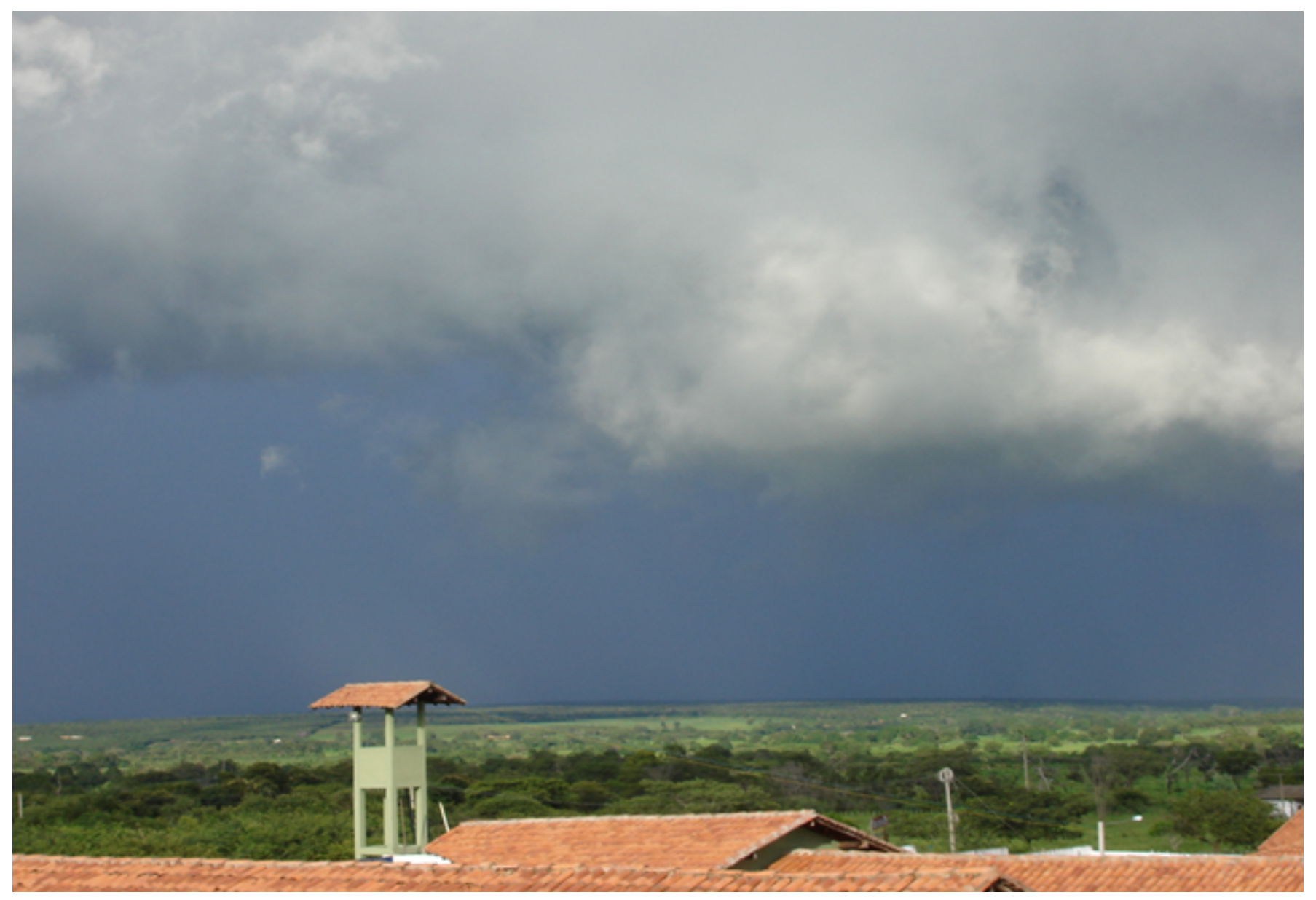

Figura 13 - VISÃO DE CIMA DOS PAVILHÕES DA PENITENCIÁRIA REGIONAL DE BOM JESU

$11]$ Doutor em Direito Internacional.

\section{PUBLIQUE SEU ARTIGO CIENTÍFICO EM:}

https://www.nucleodoconhecimento.com.br/enviar-artigo-cientifico-para-submissao 